University of Nebraska - Lincoln

DigitalCommons@University of Nebraska - Lincoln

2010

STATUS AND TREND OF COTTONWOOD FORESTS ALONG THE MISSOURI RIVER

\author{
Mark D. Dixon \\ University of South Dakota \\ W. Carter Johnson \\ South Dakota State University \\ Michael L. Scott \\ US Geological Survey \\ Daniel Bowen \\ Benedictine College
}

Follow this and additional works at: https://digitalcommons.unl.edu/usarmyceomaha

Part of the Civil and Environmental Engineering Commons

Dixon, Mark D.; Johnson, W. Carter; Scott, Michael L.; and Bowen, Daniel, "STATUS AND TREND OF COTTONWOOD FORESTS ALONG THE MISSOURI RIVER" (2010). US Army Corps of Engineers. 78.

https://digitalcommons.unl.edu/usarmyceomaha/78

This Article is brought to you for free and open access by the U.S. Department of Defense at DigitalCommons@University of Nebraska - Lincoln. It has been accepted for inclusion in US Army Corps of Engineers by an authorized administrator of DigitalCommons@University of Nebraska - Lincoln. 


\section{STATUS AND TREND OF COTTONWOOD FORESTS ALONG THE MISSOURI RIVER}

Final Report to U.S. Army Corps of Engineers

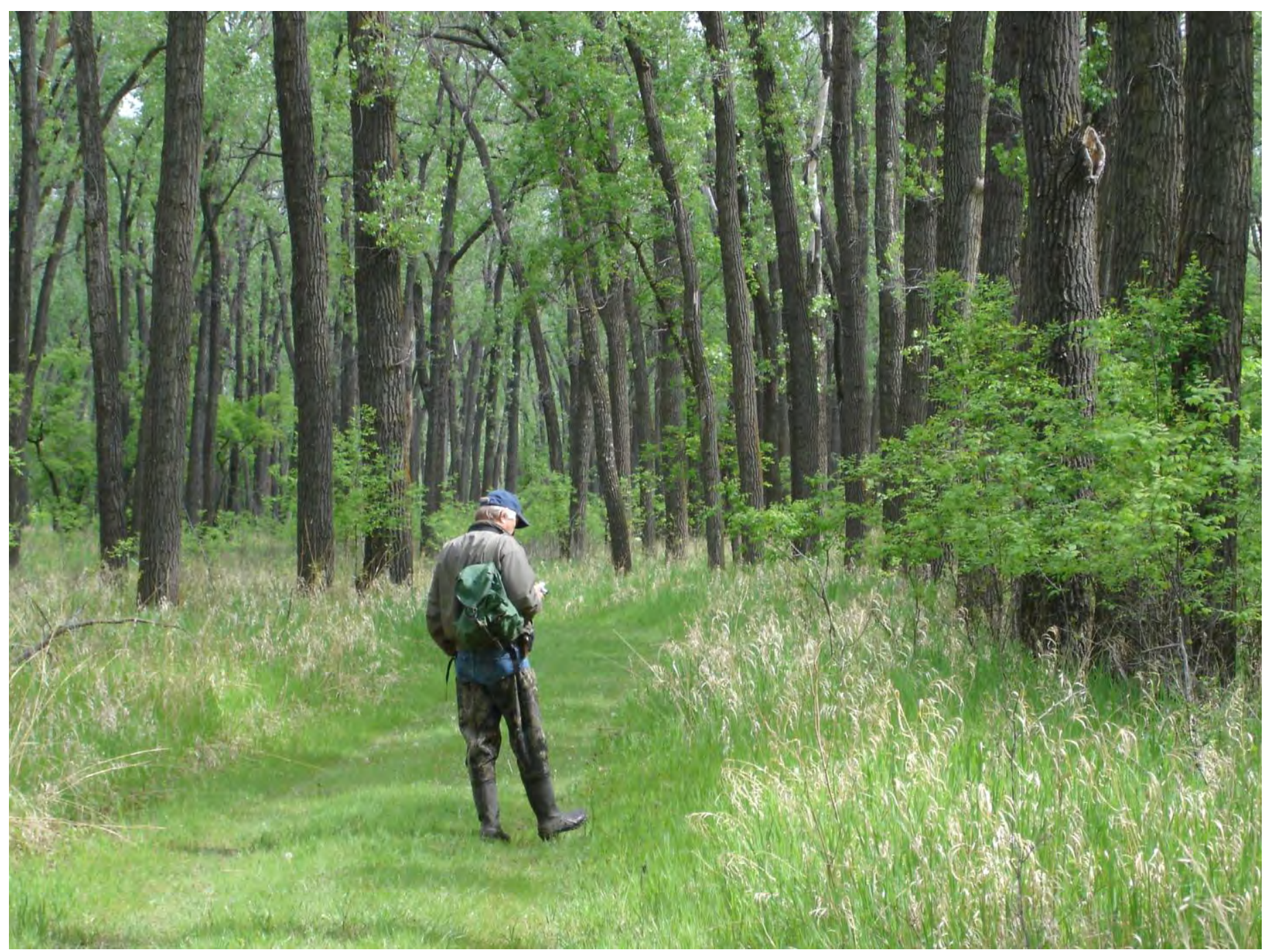

Mark D. Dixon, W. Carter Johnson, Michael L. Scott, and Daniel Bowen

March 3, 2010 


\section{TABLE OF CONTENTS}

Section

Beginning Page

Prospectus

Abstract

Introduction

Methods

Study Segments $\quad 6$

GIS Mapping $\quad 7$

Reconstruction of Pre-settlement Overstory Composition 10

Vegetation Sampling 10

Data Reduction and Analysis $\quad 15$

$\begin{array}{ll}\text { Findings and Discussion } & 17\end{array}$

Segment 13 (RM 595-365) 17

Segment 10 (RM 811.1-753) 20

Segments 8 and 9 (RM 880-841 and 841-811.1) 23

Segment 6 (RM 1072.3-987.4) 25

Segment 4 (RM 1390-1304 and 1304-1286) 27

Segment 2 (RM 1771.3-1543.3) 30

Segment 0 (RM 2073.4-1917) 33

Landscape Changes and Status of Cottonwood across all Segments 35

$\begin{array}{lr}\text { Conclusion } & 37\end{array}$

$\begin{array}{ll}\text { Suggestions for Further Study } & 38\end{array}$

$\begin{array}{lr}\text { Acknowledgments } & 39\end{array}$

$\begin{array}{ll}\text { Literature Cited } & 41\end{array}$

$\begin{array}{lr}\text { Tables } & 46\end{array}$

$\begin{array}{lr}\text { Figure Captions } & 49\end{array}$ 
Figures

53

Appendix Captions

82

Appendix A: GIS Maps of Study Segments

85 


\title{
STATUS AND TREND OF COTTONWOOD FORESTS ALONG THE MISSOURI RIVER
}

by

\author{
Mark D. Dixon ${ }^{1}$, W. Carter Johnson ${ }^{2}$, Michael L. Scott ${ }^{3}$, and Daniel Bowen ${ }^{4}$ \\ ${ }^{1}$ Department of Biology, University of South Dakota, Vermillion, South Dakota \\ ${ }^{2}$ Department of Horticulture, Forestry, Landscape, and Parks, \\ South Dakota State University, Brookings, South Dakota \\ ${ }^{3}$ US Geological Survey, Fort Collins, Colorado \\ ${ }^{4}$ Biology Department, Benedictine College, Atchison, Kansas
}

March 3, 2010

\section{PROSPECTUS}

- We used GIS-based mapping and field sampling to assess the current extent, historic change, age distribution, and vegetation composition of cottonwood stands along eight Missouri River segments. Study segments included all of the unchannelized and unimpounded segments $(0,2,4,6,8,10)$ between Fort Benton, MT and Kansas City, MO, along with one channelized (13) and two partially impounded segments $(6,9)$. We sampled vegetation in a total of 332 sites, of which 216 were intact cottonwood stands.

- The Missouri River valley has been transformed since 1892 from a landscape dominated by floodplain forest and grassland, to one dominated by agricultural cropland and river impoundments. The areas of forest, shrubland, grassland, and sandbars have declined sharply on most study segments.

- Forest and shrubland vegetation declined steeply (47\%) from 1892 to 2006 , primarily due to agricultural conversion (on unimpounded reaches) and reservoir filling (on partially impounded reaches). These estimates do not include the areas of the larger reservoirs on the system (Sakakawea, Oahe, Fort Peck). If these were included, the total percentage loss of forest would be much greater.

- Most current cottonwood stands are $>50$ years old $(62 \%)$, with only $14 \%$ of stands establishing in the last 25 years. Regeneration is not keeping pace with loss of cottonwoods due to senescence or land use conversions under current management regimes, as reduced 
rates of channel migration and sandbar formation limit opportunities for new cottonwood seedling establishment.

- In a sense, the large cottonwood forests remaining across much of the floodplain are a legacy of the past and could be thought of as "the living dead", currently helping support a high diversity of plants and animals, but unlikely to be replaced by regeneration in the future. Reversing this trend will require innovative thinking coupled with actions to restore or replicate the dynamic river processes that originally formed and sustained the cottonwood ecosystem.

\begin{abstract}
From 2007-2009, we studied the current (2006) and historic (1892, mid-1950s) extent, current age distribution, and plant species composition of plains cottonwood (Populus deltoides) and noncottonwood riparian stands along eight study segments of the Missouri River between Fort Benton, Montana and Kansas City Missouri, covering 930 river miles (1500 km) or over 1/3 of the river's length. These segments included all of the unchannelized and unimpounded segments below Fort Benton, as well as portions of two impounded and one channelized segment. Based on GIS analyses of historic maps and aerial photography, the combined area of forests, woodlands, and shrublands in the historic floodplain declined $47 \%$ across all study segments from 1892 to 2006, with losses linked to clearing for human land uses (primarily agricultural cropland) or inundation by reservoirs. Most forest loss occurred between 1892 and the 1950s, while most shrubland loss has occurred from the 1950s to 2006. As of 2006, we estimate that a total of 75,600 hectares (186,900 acres) of shrubland, woodland, and forest occurred within the mapped area of the eight study segments, with 66,800 hectares $(165,000$ acres) or $88 \%$ of the total, composed of patch types which contain cottonwood as a significant component. Most (62\%) of the cottonwood area is composed of stands $>50$ years old, and only $14 \%$ is from stands that have recruited in the last 25 years. These patterns, along with significant historic declines in shrubland and sandbar area on most segments, indicate that the fluvial geomorphic dynamics that drive cottonwood recruitment have been reduced, and cottonwood regeneration compromised, under the river management practices of at least the last 25-30 years. A significant proportion (24\%) of forest in the 25-50 year age class, however, suggested that a temporary pulse in recruitment accompanied geomorphic adjustments in the channel during the first 2-3 decades after dam closure on some segments. We sampled plant species composition and vegetation structure across an age gradient of cottonwood and non-cottonwood riparian stands in each study segment, with a total of 332 stands sampled, of which 216 were relatively intact natural cottonwood stands. Indices of plant species richness, wetland affinity, and floristic quality differed among stands and study segments, providing possible metrics for evaluating stand- and segmentlevel differences in biotic integrity. Segments 4 (below Garrison Dam) and 10 (below Gavins Point
\end{abstract}


Dam) had the highest stand-level species richness ( $\sim 35$ species per stand) and highest floristic quality (Coefficient of Conservatism values) of all segments, while segment 6 (below Oahe Dam) had the lowest of each. Stressors that may influence segment-level vegetation and landscape patterns include land management (e.g., grazing, vegetation management); forest clearing for agricultural cropland and urban or exurban expansion; channel incision and cessation of overbank flooding below dams; disruption of sediment supply and transport, with resultant declines in formation of alluvial surfaces needed for cottonwood recruitment; and aggradation with resultant water table rise adjacent to river-reservoir delta areas. In the report that follows, we provide summaries of current and historic land cover, cottonwood age distribution, and vegetation patterns for each of the eight study segments, as well as an overview across all segments.

\section{INTRODUCTION}

Plains cottonwood (Populus deltoides Marsh. Subsp. monilifera (Ait.) Eckenw.) forests were historically a major component of the floodplain of the Missouri and other Great Plains rivers. Floods maintained the ecological health of these forests by providing moisture to sustain the growth of trees and wetland plants, depositing fine sediments and nutrients that enhanced the fertility of floodplain soils, stimulating decomposition of leaves and woody debris, dispersing seeds of floodplain trees, and forming sediment bars that provided seedbeds for establishing new cottonwood and willow (Salix spp.) stands. On many western rivers, major changes in flow regime occurred following the advent of flow regulation in the mid- $20^{\text {th }}$ century, leading to chronic recruitment failure by cottonwood on meandering rivers, with long-term implications for landscape configuration and biodiversity (Johnson et al. 1976, Rood and Mahoney 1990, Johnson 1992, Miller et al. 1995). The Bald Eagle (Haliaeetus leucocephalus) may be dependent on large, mature cottonwood trees that occur in older stands for nesting and roosting habitat along the Missouri. Maximal biodiversity in the riparian landscape may occur with a dynamic mix of young, mature, and old cottonwood stands, driven by river flooding and channel migration (Johnson 1992).

In the 1950s and 1960s, the Pick-Sloan Plan resulted in the construction of a series of dams on the upper basin of the Missouri River, drowning forests upstream of the dams and greatly altering flow patterns and sediment transport downstream (Schneiders 1999, NRC 2002). On the lower Missouri, bank stabilization, building of levees, and channelization have greatly altered the river channel itself, as well as landscape patterns in the historic floodplain and its forests. The elimination of normal flow and sediment patterns are blamed for a host of natural resource problems along the Missouri, including the lack of sandbar nesting habitat for endangered bird species, poor spawning conditions for native river fishes, reductions in Bald Eagle nesting habitat, and declines in establishment of new cottonwood stands (NRC 2002). Existing forests continue to serve as important habitat for the Bald 
Eagle, migratory songbirds (Gentry et al. 2006), and many other woodland species. However, present forests are aging, rates of new forest establishment appear to be declining, and other factors, such as clearing and bank erosion, are reducing the area of existing forests (Hesse et al. 1988). Furthermore, changes in flow patterns and the absence of overbank flooding over the last 50 years may be fundamentally changing the species composition, structure, and trajectories of change within these remnant forests.

The system of 6 large mainstem dams in the upper $2 / 3$ of the river and channelization on the lower $1 / 3$ creates unique challenges and unique conditions for cottonwood on different portions of the river, with a relatively free-flowing (several smaller dams occur upstream), but geologically-constrained segment (our segment 0, in the Wild and Scenic River in Montana) upstream of Fort Peck Reservoir; inter-reservoir segments between Fort Peck and Sakakawea (segment 2), Garrison Dam (Sakakawea) and Oahe (segment 4), Oahe and Big Bend (segment 6), and Fort Randall Dam (Francis Case) and Lewis and Clark Lake (segment 8/9); partially impounded segments 6 and 9; an unimpounded and unchannelized segment downstream from Gavins Point Dam (segment 10), and segments in the channelized and leveed portion of the river, such as segment 13. Johnson (2002) suggested that these different reach types, in terms of management regime, may lead to important ecological differences among reaches and to the creation of novel habitats (e.g., reservoir deltas, etc.) that may contribute to biodiversity in the system.

Forests along all portions of a regulated reach may suffer from lack of a seasonal flood pulse that moves sediment to create recruitment seedbeds, transports and deposits seeds of cottonwood and other species, and moistens floodplain soils. In addition to changes in flow patterns, segments that are downstream from dams may suffer sediment deficits and channel incision, due to sediment storage within the upstream reservoir. Channel incision further isolates the historic floodplain from the river, effectively raising the level of the floodplain relative to the river and reducing the potential for overbank flooding. Sediment deficits may limit the formation of sediment bars that are necessary for cottonwood recruitment, Piping Plover (Charadrius melodus) and Interior Least Tern (Sternula antillarum athalassos) nesting, and other ecological functions. However, at the downstream end of inter-reservoir segments, particularly where a major sediment-bearing tributary enters just upstream of the reservoir (e.g., White River in Lake Francis Case, Bad River upstream of Lake Sharpe, Niobrara River upstream of Lewis and Clark Lake), sediment aggradation and rising water tables may kill or stress existing forests, as reservoir sedimentation and delta formation leads to the creation of aquatic/riparian delta habitats. During prolonged dry periods, the shores and upstream ends of some reservoirs may become exposed, enabling temporary colonization by cottonwood and other riparian species (but lost when reservoirs fill up again). On the channelized segments on the Lower Missouri, flooding and sediment dynamics are constrained by bank stabilization, wing dikes, and 
levees. Yet, flooding may still occur here on either side of the levee during high flow events, with potential recruitment occurring on farmland and other open habitats.

This project was conducted in support of the U.S. Fish and Wildlife Service's Biological Opinion on the Missouri River in regard to reasonable and prudent measures for the Bald Eagle, and was motivated by the need to assess the current status of cottonwood forests along the Missouri River, including their composition, structure, health, areal extent. Data and conclusions derived from this project will be used by the US Army Corps of Engineers to develop a Cottonwood Community Model using the HEAT methodology for 6 moderate to high priority Missouri River segments for the Bald Eagle (segments $4,6,8,9,10$, and 13). This model will be used to evaluate the present condition of the cottonwood community and forecast future conditions under a range of alternatives for cottonwood management actions.

Our specific aims were to determine the following:

1. Present-day land cover within the historic Missouri River floodplain, including the distribution of cottonwood forest and early successional cottonwood sites;

2. Historic land cover patterns and forest distribution along the Missouri, particularly baseline pre-dam conditions, and changes from these historic pre-dam patterns to present-day patterns;

3. The present-day successional stage and age distribution of riparian woody vegetation patches, particularly those containing cottonwood;

4. The plant species composition and structure within existing cottonwood stands, disturbed cottonwood, and non-cottonwood riparian shrublands and forests, across a successional gradient from sapling stands to old growth stands;

5. Included in \#4, the characteristics of the plant species occurring in these stands, in terms of their affinity for wetland habitats and their affinity or dependence on undisturbed natural habitats (i.e., the floristic quality" of the vegetation) and use these as indices of stand-level and segment-level biological integrity.

Here we summarize our findings for the eight study segments in terms of current (2006) and historic (1892, 1950s) land cover, the absolute and relative area of different age classes of cottonwood stands, and analysis of vegetation (trees, shrubs, herbs) data collected within each age class of cottonwood, disturbed cottonwood, and non-cottonwood stands sampled in 2007-2009. 


\section{METHODS}

\section{Study Segments}

We mapped and sampled 8 Missouri River segments (Table 1, Figure 1), from Kansas City, Missouri to Fort Benton, Montana, including approximately 930 river miles (1500 km), which constitutes roughly $1 / 3$ the length of the entire river. The study area for this effort includes river reaches identified as high and moderate priority sites for Bald Eagle compliance with the Missouri River Biological Opinion. They are segments 4: Garrison Dam to Lake Oahe Headwaters south of Bismarck, ND (RM 1390 to RM 1286), 6: Oahe Dam to Big Bend Dam (RM 1072.3 to RM 987.4), 8: Fort Randall Dam to the Running Water Bridge (near Springfield, SD), just below the Niobrara River confluence (RM 880.0 to RM 841.0), 9: Running Water Bridge to Gavins Point Dam, including Lewis \& Clark Reservoir (RM 841.0 to RM 811.1), 10: Gavins Point Dam to Ponca, NE (RM 811.1 to RM 753.0) and 13: Platte River mouth to Kansas City, MO (RM 595.5 to 365.5) of the Missouri River. In addition, we also included segment 2: Fort Peck Dam to Lake Sakakawea Headwaters near Williston, ND (RM 1771.3 to RM 1543.3), and a free-flowing segment within the Wild and Scenic River reach (RM 2073.4 to 1917) upstream of Fort Peck Lake (segment 0). Inclusion of segment 2 means that all inter-reservoir segments below Fort Peck were sampled and mapped, while segment 0 potentially provided a reference reach that was less impacted by flow regulation (Galat and Lipkin 2000). Our study segment boundaries may differ slightly from other published definitions of these segments and are based on 1960s river miles.

For mapping purposes, study area boundaries on each segment were defined by the extent of the segment, in river miles (see above) and laterally by the valley wall. The lateral boundary was determined by digitizing the break between the low topographic relief of the valley and the steep slopes of the bluffs, using county mosaic Digital Raster Graphic (DRG) scans of the USGS 7.5 minute quarter quadrangle maps (obtained from USDA NRCS Geospatial Data Gateway, http://datagateway.nrcs.usda.gov/). These lateral boundaries were sometimes adjusted to account for minor registration problems or lateral shifting of the river channel or reservoir, or to include sampling sites that occurred at the bluff-valley boundary or in tributaries.

On segment 10 , the valley was very wide $(>16 \mathrm{~km})$ in places and the 1892 Missouri River Commission (MRC) maps did not always extend to the valley wall. Because of this, we truncated the lateral boundary of the study segment at the lateral extent of the 1892 MRC maps, or the valley wall, whichever was closer. Exceptions to this lateral boundary were in the vicinity of the towns of Vermillion and Yankton, SD. Because we were interested in mapping historic urban expansion in these two areas, we extended the study area boundary to include portions of the upland within or adjacent to the 2006 extent of Vermillion and Yankton. 
Segment 13 was a very long segment (230 miles), within a wide valley, and with similar limitations on the width of coverage of the 1892 MRC maps and our aerial photography. Because of these constraints, we limited the mapped area of segment 13 to within $4.8 \mathrm{~km}$ ( 3 miles) on each side of the river centerline or to the valley wall, whichever was closer.

\section{GIS Mapping}

\section{Land Cover Mapping}

We mapped current (2006) land cover on each river segment by interpreting and digitizing 2006 county mosaic orthophotography from the National Agricultural Imagery Project (NAIP), obtained from the USDA NRCS Geospatial Data Gateway (http://datagateway.nrcs.usda.gov/). In the case of segment 10 (Figure 2), these were supplemented with 2008 NAIP imagery for delineation of particular features (e.g., constructed sandbars and backwaters). The NAIP imagery was in natural color, and

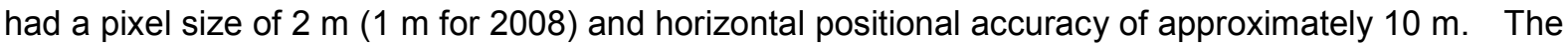
projection for the imagery and for all subsequent shapefiles and geodatabases in ArcGIS 9.2 was NAD 1983 with UTM Zones 12N (segment 0), 13N (segment 2), 14N (segments 4, 6, 8, 9, 10), or 15N (segment 13). Digitizing was done on the screen (heads-up" digitizing) with the image at a scale of 1:10,000. For particularly large and simple polygons (e.g., agricultural cropland), we sometimes zoomed out to a resolution of 1:24,000 for interpretation and digitizing, and sometimes zoomed in to scales finer than 1:10,000 for particularly complex polygons or for vegetation types that were difficult to discern. A minimum mapping unit of 1 hectare (2.47 acres) was used, although all polygons were retained in a vector format. Hence, for the most part, patches $<1$ hectare were not mapped, but were effectively merged with the surrounding dominant land cover (e.g., agricultural cropland). We developed our own land cover classification system specifically for the vegetation types encountered along the Missouri River and based upon our study goals and the resolution of our imagery. A list and short description of the land cover categories are given in Table 2.

We also interpreted and digitized land cover from the 1892 maps and 1950s aerial photography (USDA) for each river segment, and 1983/84 (NHAP) for segment 10. The 1892 land cover was based on digitizing the vegetation type designations on the Missouri River Commission (MRC) maps, published in 1895. We obtained digital, georeferenced images of the MRC maps from the U.S. Army Corps of Engineers, Omaha District (Jon Kragt, USACE, Omaha, personal communication). These maps were originally at a scale of 1:63,360 with a scanned pixel resolution in ArcGIS of $4.6 \mathrm{~m}$. Original maps were in latitude-longitude, and scanned georeferenced images were in the Albers projection. Some adjustments were necessary for the MRC maps on segment 0 to correct for lateral shifting of the images (Tammy Fancher, USGS, Fort Collins, CO, personal communication). Because of the coarser nature of these images, we interpreted and screen-digitized at a scale of 1:24,000 for most polygons. Land cover classes in the 1892 map differed somewhat from what we used for the 
2006 land cover. Because of this, comparisons between the 2006 and 1892 landscape composition required determination of comparable patch types and lumping of others. For some patch types (e.g., willows, bushes, sandbar), it was difficult to discern unambiguously what criteria were used in classification in the MRC maps, and whether our classes were completely comparable (e.g., some young recruitment sites for cottonwood could have been coded as sandbar' in the 1890s imagery). These limitations should be taken into account when interpreting historic changes in vegetation between the 1892 maps and the 2006 orthophotographs.

For our forest age class mapping, and for mapping of 1950s and (for segment 10) 1980s land cover, we obtained and geo-rectified aerial photography from the mid- to late-1950s (1955-57 when possible) and the 1980s (NHAP1 project, 1980-87). For segment 10, we also had access to fine-resolution $(0.3 \mathrm{~m})$ natural color digital orthophotography from 1997, supplied by the US Army Corps of Engineers, with similar imagery for 1998 on segments 8 and 9 . For segment 13, we acquired black-and-white digital orthophotography (USGS) from 1999. These 1990s imagery were not digitized, but were used for interpreting younger forest/shrubland age classes in our age class mapping (see next section). 1950s imagery was black-and-white aerial photography flown for the USDA Commodity Stabilization Service of the FSA (Farm Service Administration), originally at 1:20,000 scale, and was obtained principally through the USDA Aerial Photography Field Office (http://www.apfo.usda.gov/). These images were obtained as 25 micron digital scans, with a pixel resolution of approximately $0.5-0.6 \mathrm{~m}$. For segment 10, we also used some 1950s imagery that we had available as hard copy photographs, and scanned these to a pixel resolution of 2.8 meters. A few coarser scans of 1953 imagery from the USDA Soil Conservation Service (also FSA), originally shot at 1:63,360 scale and scanned at $200 \mathrm{dpi}$, were used to fill in gaps in coverage of the finer resolution 1955/56 imagery. Aerial photography from the 1980s was obtained from the USGS NHAP1 project. The imagery was color-infrared, shot at an original scale of 1:60,000 and scanned at 21 microns, for a resulting pixel resolution of approximately $1.3 \mathrm{~m}$. Imagery was obtained from the USDA APFO and the USGS EROS Data Center (http://eros.usgs.gov/).

For geo-rectification, we used the 2006 NAIP orthophotography as our base map and referenced historical imagery to it. We used the geo-rectification tool in ArcGIS and selected approximately 5-20 points common to both images (e.g., road intersections, corners of buildings, trees, bridges, etc.) as control points for geo-referencing the historic image to the base map. We applied $1^{\text {st }}$ order or $2^{\text {nd }}$ order transformations in the geo-rectification process, depending on the degree of distortion in the image and the RMS (root mean square) error of the rectification process, aiming for an error less than $5 \mathrm{~m}$, and preferably closer to 2-3 $\mathrm{m}$. All interpretation and digitizing were done on the rectified images. 
Land cover maps and age class maps (see below) were improved by field reconnaissance (groundtruthing). Ground-truthing consisted of boating the river or driving roads in the floodplain and comparing classified land cover with observations on the ground. Field ground-truthing was the primary means of differentiated cottonwood from non-cottonwood shrubland and forest sites, rather than trying to determine species composition in woodlands and forest from the aerial imagery. The only major exceptions were on more remote portions of the downstream end (subreach 4) of segment 4 , where differentiation of some cottonwood vs. non-cottonwood shrubland and young forest stands had to be done using the imagery alone. Because distinguishing cottonwood and non-cottonwood sites was the main aim of the ground-truthing, and because any observed discrepancies were corrected in the GIS files, we did not calculate estimates of classification error.

\section{Age Class Mapping}

We used the 1892 MRC maps, aerial photography from the mid-1950s (black-and-white) and 1980s (color infrared), 2006 NAIP orthophotography (in true color), and, when available, late 1990s orthophotography (black-and-white or color infrared), to map approximate age classes of cottonwood and non-cottonwood shrubland, woodland, and forest. We delineated approximate stand age (see Figure 3 for an example of an age class map) using the following steps: (1) selected polygons on the 2006 land cover that corresponded to cottonwood forest, woodland, shrubland, or vegetated sandbar categories; (2) visually overlaid these polygons in ArcGIS with historic georeferenced maps or photographs from 1997/98, the early to mid-1980s, mid- to late 1950s, and 1892; (3) determined the approximate photograph/map interval during which the present woody vegetation colonized the polygon of interest (e.g., converted from unvegetated sandbar to woody vegetation); (4) assigned the polygon, or portions of it, the age class $(1=>114$ years, $2=50-114$ years, $3=25-50$ years, $4=10-25$ years, $5=<10$ years) consistent with that establishment interval. All ages were expressed relative to the year 2006. In some cases, different parts of a given polygon differed in age class, and we split the polygon into multiple polygons of woody vegetation with different ages. Further refinement and correction of stand ages were accomplished via field reconnaissance. In some cases, particularly on segments 0,2 , and 4 , this included aging stands via tree-coring.

\section{Land Cover Transitions on Segment 10}

On segment 10, we supplemented our other, polygon-based land cover mapping by examining land cover transitions across a series of points distributed in a grid across the study area. Using Excel and ArcGIS, we created a shapefile containing a grid of approximately 3000 points (spaced $250 \mathrm{~m}$ apart in the North-South direction and $1000 \mathrm{~m}$ in the East-West) within a 3-mile (4.8 km) buffer of the river thalweg along segment 10 . We clipped this point grid to the study area boundaries, excluding grid points that occurred outside the boundary. Overlaying this grid on top of georeferenced imagery from 1892, 1955/56, 1983/84, 1997, and 2006, we then identified the land cover class that was present at that point on all of the different image years. For each point, we entered the land cover 
class for each of the five dates as attributes in the ArcGIS point shapefile. Analysis of change was based on tallying the number of transitions from one land cover class to another (e.g., the proportion of points that changed from riparian forest to agriculture between dates). Because of missing imagery, data were not available from all points for all years. Hence, land cover transitions were assessed using only points that were in common among the 1950s, 1980s, and 2006 imagery (2114 total points). In this report, we only focus on land cover transitions that have occurred in the postdam period: the intervals 1956-1984, 1984-2006, and 1956-2006. The emphasis on the post-dam dates was so that estimates of recent land cover transition rates could be determined and potentially used to forecast future landscape change using state-and-transition matrix models or other approaches. Follow up work may include projecting future landscape composition based on these recent trajectories and analyzing rates of land cover change over other intervals (e.g., 1892-1956, 1984-1997, etc.).

\section{Reconstruction of Pre-settlement Overstory Composition}

We obtained, interpreted, and transcribed the witness tree data from the General Land Office Survey notes for the Missouri River historic floodplain in Clay, Union, and Yankton counties, South Dakota and Dixon and Cedar counties, Nebraska, within segment 10. The bulk of the records were from 1857-59 on the Nebraska side and 1860-61 on the South Dakota side, although some supplementary survey data were from other years $(1862,1867,1869)$. Data were available for 1059 section or quarter section corners (although not all of these had trees) and witness trees were also recorded at other locations along the survey lines. The dataset included information on 917 witness trees, across 12 species. Stem diameter measurements (diameter at breast height) were available for most of the trees. We tallied the frequency and basal area of all witness trees in the study area and compared them to relative density and basal area data from present-day (2007) vegetation sampling within cottonwood stands in segments 8 and 10 (Figure 4).

\section{Vegetation Sampling}

Three methods were used in concert to sample the vegetation of cottonwood stands in the Missouri River floodplain. Sampling included characterization of (1) overstory composition and structure using the point-centered quarter method or (on pole and sapling sites with few tree-sized individuals) fixed radius circular plots, or complete plot census methods; (2) shrub/sapling composition, density, and cover using belt sampling and line intercept methods; and (3) herbaceous species composition and cover using $1 \times 1 \mathrm{~m}$ quadrats. 


\section{Stand and Sampling Point Selection}

We stratified each river segment into longitudinally into three subreaches, based on river miles or geomorphic considerations. Segments 2 and 4 were exceptions, with each divided into four subreaches. On both of these segments, subreach 4 represented a downstream extension of the original study area extent. When possible, we sampled 10 cottonwood stands within each sub-reach, for a total of 30 stands in each river segment. Within each subreach, we attempted to sample 2 stands from each of the following age classes: >114 years (old growth), 50-114 years (mature), 25-50 years (intermediate), 10-25 years (pole), and $<10$ years (sapling). Approximate stand ages were determined by overlaying historical maps and aerial photographs by the methods outlined above (in the section detailing the GIS mapping methods), and in some cases by coring and aging trees. Beginning in 2008, we also sampled disturbed cottonwood stands and non-cottonwood stands in the 6 priority segments $(4,6,8 / 9,10$, and 13), with a goal of 12 non-cottonwood and 6 disturbed cottonwood stands per segment, and attempted to obtain at least some stands in each of the same age classes. Constraints on site availability meant that these goals were not always attained for all of the segments. Because of small numbers of stands in segment 9 , data for segments 8 and 9 were combined (denoted segment 8/9) for most analyses.

Initial (in 2007) criteria for stand selection of undisturbed cottonwood forests included:

- At least $10-15 \%$ overstory cover by cottonwood

- An unmanaged or natural" overstory, shrub, and herbaceous layer

- No or minimal selective clearing of overstory trees

- No selective clearing of red cedar, Russian olive, or other species

- No campgrounds or sites with otherwise managed understories

- Patch size of at least 4-6 hectares (10-15 acres) for pole through old growth stands. Seedling/sapling sites could be smaller, down to 1 ha. (2.5 acres) or less.

- A stand, or the area of the stand included in a given sample, should be relatively homogeneous in terms of age and management

- No mixture of our age classes

- Preferably, no mixture of samples across obviously different cohorts of cottonwoods, even if the stand as a whole falls within a single crude age class (as defined above)

- Avoid mixing portions of a stand with different past management regimes or obviously different vegetation structure (e.g., big differences in tree density, abundance of red cedar, etc.)

Additional disturbed and non-cottonwood stands sampled in 2008 diverged from these criteria in terms of $\%$ overhead cover of cottonwood (non-cottonwood sites were $<10-15 \%$ cottonwood overstory cover) and disturbance (we explicitly selected sites with some degree of anthropogenic disturbance 
for the disturbed" cottonwood sites). These stands were sampled to provide a wider range of cottonwood or riparian forest stand conditions and indices of floristic quality and to enable inclusion of these other forests within the cottonwood community model being developed by USACE.

In 2009 we added additional cottonwood and non-cottonwood sites on the South Dakota study segments $(6,8,9$, and 10$)$, in part to improve sample size in under-sampled age and stand type categories. We also sampled several (10) planted cottonwood stands on segments 6 and 8 . Data from planted cottonwood sites were collected to enable comparison between planted and naturally occurring stands in terms of stand structure and overstory and understory species composition (e.g., richness, floristic quality, etc.). Analyses of the planted stand data, however, are not included in this report.

Table 1 indicates the numbers and types of stands sampled in the eight study segments. A total of 216 cottonwood, 32 disturbed cottonwood, 74 non-cottonwood, and 10 planted cottonwood stands, for a total of 332 sites (plus one herbaceous former cottonwood site), were sampled in 2007-2009. Of these, 80 of the cottonwood stands, 23 of the non-cottonwood stands, and 8 of the planted cottonwood stands were in the sapling or pole (<25 years) age classes. Very few (3) disturbed stands in the sapling or pole (<25 years) age classes were identified and sampled. 30 stands in segment 4 were resurveys of sites previously sampled in 1969-70 (Keammerer et al. 1975, Johnson et al. 1976).

\section{Overstory Sampling}

For most stands, we used the point-centered quarter method (Cottam and Curtis 1956) for sampling and characterizing stand-level tree species composition, density, and basal area. This method provides an efficient technique for rapidly surveying stand characteristics, enabling a crew of three to easily sample a stand in 4-8 hours. These methods are consistent with those used by Carter Johnson (Johnson et al. 1976) on the Garrison to Oahe reach (segment 4) of the Missouri River in North Dakota in 1969-70. We resampled 30 of the 34 stands originally sampled by Johnson and Keammerer (Johnson et al. 1976, Keammerer et al. 1975). Further analysis of these data will enable assessment of the long-term effects of flow regulation and successional change during the last 39 years within this segment.

On sites sampled using the point-centered quarter method, forty points were sampled per stand, with 4 trees per point (160 total per stand). At each point, we divided the area into four 90 degree quadrants, relative to the transect bearing and a line perpendicular to it. Within each of these quadrants, we located the nearest live tree with a trunk diameter at breast height $(\mathrm{dbh}) \geq 10 \mathrm{~cm}$, identified it to species, measured the dbh to the nearest centimeter, and measured the distance from the point to the center of the tree trunk to the nearest 0.1 meters or finer. For trees with multiple 
trunks, we measured and recorded all stems that equaled or exceeded $10 \mathrm{~cm} \mathrm{dbh}$. If the nearest tree in a quadrant was dead, we recorded the species (if known), dbh, and distance from point, and then looked for the nearest live tree within the quadrant. In cases where no live tree could be located within a reasonable distance in the quadrant (e.g., > $35 \mathrm{~m}$ ), the quadrant was recorded as open." Distances were measured using an electronic measuring device (Sonin multi-measure), optical rangefinder, or measuring tapes. For sites with open quadrants, we applied a correction factor to estimates of stem density, using the simple correction suggested by Dahdouh-Guebas and Koedam (2006). In addition to measuring trees, we also noted and recorded whether each tree measured had a liana (woody vine) growing on its trunk.

Because many or most of the cottonwoods in sapling and pole stands had stem diameters $<10 \mathrm{~cm}$ at breast height, these sites often had a large number of points (or all points) with open quadrants where a tree with $\mathrm{dbh} \geq 10 \mathrm{~cm}$ could not be measured within a reasonable distance and/or the same individual tree would have been measured more than once at multiple points. Similar difficulties occurred in some older sites that were very patchy or open in terms of tree distribution, with sometimes very long distances to the nearest tree. For such sites, a large correction factor would had to have been applied to generate density estimates, and we considered the estimates of density unreliable. Hence, for most sapling and pole sites and a few other sites of various age classes, we sampled tree density using12 fixed radius $(15 \mathrm{~m})$ circular plots instead of or in addition to the pointcentered quarter sampling. Within each circular plot, we measured and recorded the stem diameter for all tree stems $\geq 10 \mathrm{~cm} \mathrm{dbh}$. This enabled us to obtain real density estimates for points with no trees (i.e., 0 stems per unit area), whereas the point-centered quarter method requires that trees be present and cannot yield density estimates of zero.

On some sites, particularly in the Wild and Scenic segment (segment 0) in Montana, where cottonwoods often occur in smaller, linear patches paralleling the river, neither point-centered quarter nor fixed radius circular plots were effective, given the geometry of the stands. Hence, strip transects or narrow, rectangular plots were used to sample tree density, with all trees present in these plots sampled in a complete census (Michael L. Scott, USGS Fort Collins, CO, personal communication).

In the data summaries that follow, we combine data from the point-centered quarter, fixed radius plot, and complete census plot techniques, retaining the point-centered quarter estimates for most stands $>25$ years old and pole stands with few or no open quadrants.

\section{Understory Sampling}

Understory sampling characterized both the shrub and herbaceous layers. In contrast to the overstory sampling, only 12 (for shrubs) and 24 (for herbaceous layer plants) points were sampled per 
stand. These points were either on completely separate transects from those used in the overstory sampling, or were offset from the overstory transects to avoid trampling the herbaceous vegetation. These were generally arranged on four transects, as with the trees, with 6 herb points and 3 shrub points per transect.

Plants occupying the shrub layer (shrubs and tree saplings $>1 \mathrm{~m}$ tall and $<10 \mathrm{~cm} \mathrm{dbh}$ ) were sampled using the line-strip method (Lindsey 1955), using a sampling strip $2 \mathrm{~m} \times 10 \mathrm{~m}$ with a tape defining the centerline. This sampling strip began at the point and ran along the bearing of the transect. Woody stem density (\#/ha) in the shrub layer was estimated by counting all individual shrubs, saplings, and woody vines found within the sampling strip ( 1 meter to either side of the $10 \mathrm{~m}$ transect). Numbers were tallied for each species.

Percent cover was estimated by recording cover by shrubs (or saplings and woody vines) that intercepted the vertical plane of the plot centerline above $1 \mathrm{~m}$ off the ground. We noted the total distance along the 10-meter tape length with overhead shrub cover by each species and summed the contributions of individual species to get total cover. Note that this can exceed 100 percent, as different species can have overlapping coverage over the same length of tape. In 2008, we revised our data recording to enable quantification of overlapping coverage, allowing estimation of total shrub cover (without inflated estimates from overlap) on each plot. For this report, however, we have retained the data obtained from the former approach, so as to include consistent data from all sampled stands.

Plants in the herbaceous layer (herbs and woody seedlings $<1 \mathrm{~m}$ tall) were sampled using a $1 \mathrm{~m} \times 1$ $m$ sampling frame (quadrat) beginning at or centered on the sampling point. Care was taken to avoid trampling on the area prior to sampling. For this reason, we sampled the herbaceous quadrat prior to the shrub sampling. All species of non-woody vascular plants and woody seedlings were noted and recorded and their percent cover within the $1-\mathrm{m}^{2}$ quadrat estimated to the nearest $5 \%$. Species with trace occurrence were recorded as $1 \%$ cover.

Voucher specimens of plants encountered during sampling were obtained and submitted to Dr. Gary Larson of South Dakota State University. Specimens were obtained in full flowering condition when possible. When possible, we obtained voucher specimens in duplicate or triplicate, so that at least one specimen could be deposited in the C. A. Taylor Herbarium of South Dakota State University, one in the home institution (e.g., University of South Dakota, Benedictine College, USGS), and additional specimens could be donated to US Fish and Wildlife Service or National Park Service collections. 


\section{Data Reduction and Analysis}

These sampling protocols produced the following basic information: stand- and segment-level plant (vascular plant) species lists; frequency and percent cover of each species in the herbaceous layer frequency, percent cover, and density of each species in the shrub layer; and the frequency, density, basal area ( $\mathrm{m}^{2} / \mathrm{ha}$ ) and importance value (sum of percent relative frequency, density, and basal area, with a maximum value of 300 ) of each tree species. For complete census plots for trees, there was no way to calculate relative frequency separately from relative density. Hence, for those sites (mostly in segment 0 ), we computed importance value using relative basal area plus two times the relative density for each species. By assigning published wetland indicator values (Reed 1988) and Coefficients of Conservatism (C-values) (Swink and Wilhelm 1994, Taft et al. 1997, Northern Great Plains Floristic Quality Assessment Panel 2001) to species of plants, estimation was made of the wetland affinity and overall floristic quality of the vegetation in each stand.

\section{Plant Species Data Summaries and Metadata}

Each investigator was responsible for submitting a master spreadsheet listing the scientific name of each species encountered during sampling, any code names used to identify that species in the data, whether the species is native or introduced, its wetland indicator status for the relevant region, and its Coefficient of Conservatism. Wetland Indicator status codes (Reed 1988 and later updates) have been standardized by region and may be obtained from the following website: http://www.fws.gov/nwi/plants.htm or from the USDA NRCS Plants Database (http://plants.usda.gov/) (USDA, NRCS 2008). Coefficients of Conservatism (i.e., how indicative is a given species of the naturalness" or conservation value of a study site) have been developed for the flora of a number of regions (e.g., The Northern Great Plains Floristic Quality Assessment Panel 2001 for North and South Dakota, http://www.npwrc.usgs.gov/resource/plants/fqa/index.htm) and is most often used in Floristic Quality Assessment for calculating the Floristic Quality Index (Swink and Wilhelm 1994, Taft et al. 1997) or FQI. These codes can enable calculation of species- or cover-weighted average estimates of wetland affinity and overall vegetation quality or naturalness" in each stand.

For segments 6. 8, 9 and 10, we obtained Coefficient of Conservatism (C) values from a software package called Floristic Quality Assessment Computer Program, Version 1.0 (October 2000) by Gerould S. Wilhelm and Linda A. Masters, with the Dakotas database (North and South Dakota). These data were originally derived from the publication by the Northern Great Plains Floristic Quality Assessment Panel (2001), mentioned above. For species that were not found in the Dakotas database, we used the $C$ values from a 2006 draft update of the Nebraska Natural Heritage Program state list (Rolfsmeier and Steinauer 2003). In a limited number of cases (for species not listed in either the Dakotas or Nebraska lists), we used a draft list compiled for lowa (http://www.public.iastate.edu/\%7Eherbarium/coeffici.html). For segment 4, C-values were obtained 
primarily from the publication by the Northern Great Plains Floristic Quality Assessment Panel (2001) for the Dakotas. For segments 0 and 2, C-values were taken from Lesica and Husby (2001, http://nris.state.mt.us/wis/wetlands/metadata.html). In instances where C-values for particular species could not be obtained from the preferred source for that region, we used C-values for that species from neighboring states. Hence, scores from the Northern Great Plains Floristic Quality Assessment Panel (2001) were used when species encountered in segments 0 or 2 were not listed in Lesica and Husby. For segment 13, the previously mentioned Nebraska list (Rolfsmeier and Steinauer 2003) was the first choice for assigning C-values, with the Missouri List by Ladd (1997) used secondarily and the lowa list used for any species not found on the other two lists.

We calculated FQI and mean C as in Swink and Wilhelm (1994) and Taft et al. (1997), except that we included all species for which we had $C$ values, and used a value of 0 for non-native species. So, overall mean $\mathrm{C}$ and $\mathrm{FQI}$ values were computed based on the complete list of species sampled at each stand (across the herb, shrub, and tree strata). These species lists include some occurrences of plants that could only be identified to the genus level, which may be redundant with other, identified species in the same genus on the site. We also computed weighted mean $C$ values that were weighted by relative cover or importance values of the individual species in the herb and shrub strata. We obtained information on native vs. exotic status from the program and from the USDA NRCS Plants Database (USDA, NRCS 2008).

For analyses of Wetland Indicator Status, we obtained indicator scores from the appropriate regional lists (Reed 1988), obtained from the USDA NRCS Plants Database (USDA, NRCS 2008). For segments 6. 8, 9 and 10, we used lists for Regions 4 (South Dakota), 5 (Nebraska), and 3 (lowa), in that order of preference. Region 4 scores were also used for segments 2 (downstream of Fort Peck) and 4 (downstream from Garrison) in eastern Montana and North Dakota, respectively. For segment 0 , in the Wild and Scenic reach in Montana, we used the Region 9 (Northwest) list. For segment 13, we used the Region 5 (Central Plains, including Nebraska) list first, and used the Region 3 list (North Central, including Missouri and lowa) for species that were not listed for Region 5. As with C-values and FQI, we computed both unweighted average WIS scores (average of all of the species encountered at a site) and scores weighted by percent cover or importance value of herbs or shrubs. Overall scores that included both herbaceous and woody species were based only on the unweighted species lists, for mean C, FQI, and WIS.

Our numeric scale for scoring Wetland Indicator Status (W) differed from other investigators (e.g., Stromberg et al. 1996), is that we assigned a value of 5 to wetland obligate plants and a 1 to upland species (this is the opposite of the normal approach). In essence then, higher scores (closer to 5) represent higher wetland affinity in our system. We ignored + or - modifiers in our scoring (e.g., FACU, FACU- and FACU+ are scored as a 2, FAC and FAC- as 3, etc.). As with C-values and FQI, 
we computed overall (across plant strata) average W scores based both on unweighted species lists, but also computed separate estimates weighted by relative cover or importance value for herbs and shrubs.

For the analysis of differences among segments or cottonwood age classes in stand-level W scores, C-values, and species richness values, we used a factorial ANOVA, with segment and stand age (and the interaction between the two) as explanatory variables. These analyses were conducted only for cottonwood stands; both non-cottonwood and disturbed cottonwood stands were excluded. Because of small sample sizes for some stand age classes, we grouped younger age classes (<10 and 10-25 years) into a <25 year age class, and mature and old growth stands (50-114 and >114 years) into a $>50$ year age class for analysis. Comparisons among the different segments were then made using LSMEANS, as depicted in Figures 14--20.

Data entry, error checking, and production of graphics was done in MS-Excel. Most data manipulation and analysis was done in the Statistical Analysis System software (SAS®, version 9.1).

\section{FINDINGS AND DISCUSSION}

Below, we describe and interpret findings for each study segment, including present land cover, historic land cover change, cottonwood age distribution, and vegetation patterns in sampled stands. Maps of each study segment, including both historic land cover changes and forest age classes, are provided in Appendix A.

\section{Segment 13 (RM 595-365)}

Segment 13 (RM 595 to 365) occurs within the Missouri River Bank Stabilization and Navigation Project, which maintains the lower 732 miles $(1178 \mathrm{~km})$ of the river, from Sioux City to St. Louis, as a channel for barge navigation. The segment extends from the mouth of the Platte River, which enters below Omaha, to the mouth of the Kansas River, which enters in Kansas City. Although the river in this segment has been significantly modified due to channelization, the degree of hydrologic alteration is somewhat less than on inter-reservoir segments upstream (Galat and Lipkin 2000). This is because of flows contributed by tributaries, particularly the Platte, that join the Missouri downstream from the last dam (Gavins Point) near Yankton, South Dakota. Tributary contributions are even more significant, and flow regimes less impacted by upstream dams, on segments downstream from the Kansas River confluence at Kansas City. In addition, much of segment 13 (from Plattsmouth, NE to St. Joseph, MO) has experienced 0.5-1.8 $\mathrm{m}$ of channel bed aggradation, and with it, increases in flood stages for a given discharge (USACE 2004, Jacobson et al. 2009). Under regulated river flows, 
large scouring flows no longer occur that are sufficient to transport accumulated sediments from the Platte and other tributaries. These factors contribute to nearly annual spring flooding of areas on the riverward side of the levees, and much land on the protected side also floods during this time because gravity flow cannot remove the runoff. In addition, overbank flooding beyond the levees occurred during large flood events in 1993 and the mid-to-late 1990s.

In 1804 it took almost one month for the Lewis and Clark expedition to cover modern segment 13. Then the floodplain was mostly prairie with interspersed groves of trees, protected by the meanders. Currently (as of 2006), 70\% of the floodplain within a $5-\mathrm{km}$ (3-mile) buffer of the river channel is agricultural cropland, with forest comprising 9\%, grassland 7\%, and urban (including portions of St. Joseph and Kansas City, Missouri) about 4\% (Figure 3). Industrial parks cover much of the modern floodplain near Kansas City, while agricultural lands extend from Fort Leavenworth to near the Platte River. Only relatively minor land use changes occurred from the 1950s to present, with cropland area increasing from $61 \%$ to $70 \%$ and forest declining approximately $20 \%$ relative to its 1950 s area (Figures 5, 6a, 8). The strongest changes from the mid-1950s to present were major declines in shrubland area (nearly $75 \%$ loss) and grassland (39\% loss) (Figures 5, 6a). Changes from 1892 to later dates are difficult to interpret, as the Missouri River Commission maps for this segment did not designate cover types for a large portion of the interior of the floodplain. We designated a land cover class of "other" for these areas in our mapping and analysis, but suspect that most of these unclassified areas had already been converted to agricultural cropland. This river segment had already long been settled by the 1890s, and substantial habitat conversion had already likely occurred (Bragg and Tatschl 1977). Total area mapped as river sandbar declined precipitously from 1892 to the 1950s, and had nearly completely disappeared by 2006 (only 1 hectare mapped along the entire 230 mile segment) (Figures 5, 6a).

With only a few exceptions (e.g., at sampling locations), we were unable to reliably differentiate cottonwood from non-cottonwood stands in our GIS mapping of this segment. Field reconnaissance, however, suggested that cottonwoods were present in the vast majority of all woody stands in the floodplain. Nearly half (46\%) of the cottonwood area was occupied by mature stands (50-114 years) (Figure 11). Less than $5 \%$ of the forest area was judged to be $>114$ years old, although it was often difficult to determine due to the previously mentioned lack of detail on many of the 1892 Missouri River Commission maps. Areas of these mature and old forests are still being harvested on lands not protected by government or conservation group ownership. The remaining forest area was divided between $25-50$ year old stands (27\%) and stands less than 25 years old (6\% poles, $10-25$ years old; $16 \%$ saplings, $<10$ years old). Most of the $25-50$ year old forest was on the river side of the levees, having formed in tandem with channel narrowing induced by wing dikes. Conversely, with the nearly complete absence of sandbars on the segment, many of the sapling and pole stands occurred on the landward side of the levees. These recruitment patches were sometimes quite 
extensive and occurred on abandoned farmland and other open areas, as has occurred on the Big Muddy National Wildlife Refuge much farther downstream (Thogmartin et al. 2009). Recent recruitment was likely linked to overbank flooding from the large flood of 1993 and subsequent floods later in the 1990s. Flooding has occurred periodically in subsequent years as well, including during the middle of our field season in 2008. Many of these young stands are being actively removed via habitat management activities (e.g., burning of grassland) by natural resource agencies, including on Corps lands. Alternatively, if protected, these recent recruitment areas could produce significant areas of cottonwood forest within a few decades.

Average stand-level tree species richness is significantly higher in segment 13 than all other segments (Figure 14). More than 6 tree species were sampled, on average, per cottonwood stand, with a maximum of 12 species in one old growth stand and as much as 17 species in a young $(<25$ year old) non-cottonwood stand. Fewer than half as many tree species, on average, were sampled in a typical cottonwood stand within the North Dakota (segment 4) and Montana (segments 0 and 2) study areas. Most of the decline is because of progressive loss of later successional tree species as one moves upstream, with only green ash and box elder still common in the western- and northernmost segments. Numerous later successional species occur in segment 13 stands, increasing in dominance with stand age (Figure 21a,b). These include hackberry (Celtis occidentalis), box elder (Acer negundo), red and white mulberry (Morus rubra and $M$. alba, respectively), pecan (Carya illinoinensis), American sycamore (Platanus occidentalis), silver maple (Acer saccharinum), green ash (Fraxinus pennsylvanica), American elm (Ulmus americana), and others. A mix of these same species, along with roughleaf dogwood (Cornus drummondii), comprise the shrub layer in mature and older stands, while cottonwood or willow dominate the shrub layer of younger stands (Figure 22a,b). Willows (Salix exigua, S. nigra) were particularly an important component of the shrub layer on young (<25 years) non-cottonwood stands. Shrub cover was highest in younger (<25 year old) cottonwood or non-cottonwood stands, but averaged $<30 \%$ on mature and old growth stands.

On average, stand-level plant species richness, particularly of herbaceous plants, was low on segment 13, when compared to other study segments (Figure 15), although most that were present were native (Figure 16). Overall floristic "quality" as indicated by average Coefficient of Conservatism values (C-values) was intermediate compared with other study segments (Figure 17, 18). Notably, the average wetland affinity scores (numeric score for Wetland Indicator status, with $\mathrm{OBL}=5$ and $U P L=1$ ) for stands in segment 13 were significantly higher than in all other segments (Figure 19). This may reflect the fact that many of the stands in this segment still flood regularly, as occurred in 2008. In addition, it is possible that the flooding that occurred during the 2008 growing (and sampling) season may have temporarily influenced both the wetland affinity scores (increasing them) and the herbaceous species richness values (decreasing them). 


\section{Segment 10 (RM 811.1-753)}

Segment 10 is the downstream section (59-mile) of the Missouri River National Recreational River, administered by the National Park Service. Because it occurs below the farthest downstream dam (Gavins Point) in the system and is an unchannelized reach, this segment is often considered one of the more natural or least altered sections of the lower Missouri, with some physical features characteristic of the pre-regulation river (Schneiders 1999). However, flow patterns are greatly influenced by the cumulative effects of the six mainstem upstream dams. In a study comparing preand post-regulation flow patterns at 10 gauging stations (inter-reservoir, channelized, and upstream) on the Missouri, flows at Yankton exhibited the most extreme composite scores for hydrologic alteration, with significant declines in annual peak flows, increases in minimum flows, and shifts in flow timing (Galat and Lipkin 2000).

An important additional effect of these upstream dams and reservoirs has been to trap sediment, greatly diminishing downstream sediment load (NRC 2002) and leading to significant degradation of the channel bed, especially immediately downstream from Gavins Point and other dams. In contrast to inter-reservoir segments (e.g., 2, 4, 6, 8) on the Missouri, there is no reservoir downstream from Gavins Point Dam. With no downstream reservoir slackwater effect on segment 10 , significant channel degradation (measured via changes in water surface elevation) occurred along the entire length of the segment between 1960 and 2002, ranging from more than $3.0 \mathrm{~m}$ immediately below the dam (RM 808-810) to $1.4 \mathrm{~m}$ midway within the segment (RM 786) and increasing again to $2.6 \mathrm{~m}$ at the downstream end of the segment (RM 753) (WEST Consultants, Inc. 2002, USACE 2004). Declines in bed elevation and water surface elevations (at flows of 30,000 cfs) from 1956-2001 averaged approximately 2 meters over the entire segment (WEST Consultants, Inc. 2002). Further degradation has likely occurred since 2002, with total degradation immediately below Gavins Point Dam now estimated at approximately 12 feet (3.5 m) (Jacobson et al. 2009).

Segment 10 runs primarily west to east, from Yankton, South Dakota to Ponca, Nebraska, and has a wide valley (over 10 miles or $16 \mathrm{~km}$ in places), bounded by bluffs in Nebraska and South Dakota (Figure 2). Most of the segment runs closer to the bluffs on the south (Nebraska) side, with a much wider valley and more extensive historic floodplain on the north (South Dakota side). Present-day land cover (Figures $5,6 \mathrm{~b}$ ) is dominated by agricultural cropland $(77 \%)$, with the proportion of cropland increasing from upstream to downstream. Other major categories include floodplain forest (both cottonwood and non-cottonwood), the river itself, and urban/developed areas with the larger towns of Vermillion, Yankton, and Elk Point, and smaller communities of Gayville, Meckling, and Burbank. The areas of forest and river channel are nearly equal, at approximately 5000 hectares or $6-7 \%$ of the study area, with urban land cover at $5 \%$. 
Large changes in land cover have occurred since 1892 and 1955/56 (Figure 2). Much of this cumulative change had occurred by $1983 / 84$, with generally more modest changes over the next 2223 years. The area of agricultural cropland increased dramatically (over 3-fold), largely at the expense of grassland and forest, with most of the increase occurring between 1892 and 1956 (Figures 2, 5, 6b). Area of grassland, shrubland, forest, and particularly sandbars has declined strongly over time, with grassland and sandbars representing a negligible percentage of the landscape in 2006/2008. Urban expansion has also occurred in the towns (or via exurban development) in or adjacent to the river valley. Forest area has declined nearly 50\% since 1892 (Figure 9), primarily due to land use conversion to agricultural cropland (Figure 10). Declines in both sandbar area and shrubland (Figure 6b), which includes regenerating cottonwood stands, suggest that the effects of river regulation (including channel bed degradation, reduced sediment load, and flow alteration) are decreasing opportunities for new establishment of cottonwood stands. Interestingly, total forest and woodland area increased 21\% between1983/84 and 2006, while grassland (-50\%), shrubland (-51\%), and sandbar (-48\%) all declined sharply (Figure 6b). Hence, although forest area increased during that interval, the total area of woody vegetation (forest plus shrubland) was virtually unchanged from $1983 / 84$ to 2006 , decreasing by $1.5 \%$. Increases in forest area over the last 25 years appear to be primarily due to conversion of sapling and pole stands (mapped as shrublands) present in 1983/84 to forest by 2006 through growth and maturation (Figure 10). This change is reflected in the fairly high proportion of the total cottonwood stand area that is in the 25-50 year old age class (see below), with these stands having established during the 1956 1983/84 interval (Figure 11).

The age structure of the cottonwood population on segment 10 is dominated by mature (50-114 years) and intermediate-aged (25-50 years) stands, with smaller areas of old growth (>114 years) and recent (last 25 years) recruitment (Figure 11). Despite the perceived negative effect of flow regulation on cottonwood recruitment, nearly half of the present-day forest on segment 10 established after closure of Gavins Point Dam in 1956. The relatively large proportion of forest in the 25-50 year age class $(30 \%)$ contrasts with some other study segments (e.g., segments 4,6$)$ and suggests that significant cottonwood recruitment occurred in the 25 years following dam closure on segment 10 (Figure 11). Although many studies have documented declines in cottonwood recruitment below dams on meandering rivers in western North America (e.g., Rood and Mahoney 1990, Friedman et al. 1998), including on segment 4 in North Dakota (Johnson et al. 1976; Johnson 1992, 1998), others have shown that flow regulation may lead to channel narrowing, and with it, a short-lived increase in recruitment and persistence of riparian vegetation, on braided, sandbed rivers like the Platte (Johnson 1994, 1998; Scott et al. 1996; Friedman et al. 1998). Segment 10 may represent a channel morphology and geomorphic response intermediate between that of a meandering and a braided river, resulting in minor channel narrowing and a temporary recruitment pulse for cottonwood in the decades immediately following dam closure. The occurrence of historic flood of record in 1952 (peak 
of 480,000 cfs at Yankton) suggests that considerable sediment reworking and bar formation may have occurred just prior to dam closure. After dam closure, channel degradation initially could have increased the availability of sites for recruitment by exposing bars that were previously part of the channel bed. Reductions in peak flows and ice scour following dam closure would likely have led to increased survival of established vegetation on bars, enabling persistence of these cohorts. The lower proportion of stands $<25$ years old suggests, however, that this post-dam recruitment pulse was temporary, with subsequently lower rates of recruitment. The somewhat higher proportion of saplings $(11 \%)$ than poles $(7 \%)$ is likely a legacy of the high flows in 1997 , that moved considerable sediment and formed sandbars, providing nursery sites for recruitment by cottonwood and willow, as well as creating habitat for Interior Least Tern and Piping Plover nesting (Greg Pavelka, USACE, Yankton, SD, personal communication). One important consideration, however, in comparing the proportions of stand area established in the pre- and post-dam time periods is that considerable loss of older forests due to land use conversion occurred after 1892 and 1955/56 (Figures 7- 10). If the area of older lost forest was included, then the area of forest $<50$ years old would represent a much smaller percentage of total forest area.

Besides plains cottonwood, other common tree species in cottonwood stands included later successional species green ash, American elm, hackberry, white mulberry, and eastern redcedar (Juniperus virginiana). Russian olive (Elaeagnus angustifolia) and willows (Salix amygdaloides and S. lutea) frequently occurred as shrubs or small trees in younger cottonwood and non-cottonwood stands (Figure 23a,b). Tree species richness, although higher than segments farther upstream, averaged significantly lower than in segment 13, with a weighted average of 4.45 species per sampled stand (Figure 14). Average shrub cover increased with stand age and was particularly high in mature and old growth cottonwood stands (Figure 24a,b). Roughleaf dogwood (Cornus drummondii) and buckthorn (Rhamnus cathartica) dominated the shrub cover in older stands, while cottonwood and willow species (S. amygdaloides, S. lutea, S. exigua) dominated younger sites.

Compared with other study segments, cottonwood stands within segment 10 had high plant species richness (mean of 35 species/stand) (Figure 15) and high floristic quality (Figures 17, 18), as measured by average Coefficient of Conservatism values, with exotics averaging only $14 \%$ of the species sampled per stand (Figure 16). Conversely, a significantly higher proportion of tree species per stand were exotics in the three South Dakota segments $(6,8 / 9,10)$ than in the other study segments (Figure 20). These species included Russian olive, white mulberry, and common buckthorn. Eastern redcedar, a native shrub/tree species often considered invasive in the region, also appeared to have higher abundance in segment 10 (and perhaps segment 8 ) than in the other study segments. Among these species, Russian olive was primarily found on stands that established in the post-dam era ( $<50$ years old), white mulberry and buckthorn primarily in mature and older stands (>50 years), and redcedar primarily in stands $>25$ years old (Figures 23, 24). Native 
later successional species, including green ash and American elm, were notably scarce on stands less than 50 years old (Figures 23, 24). Redcedar, Russian olive, and white mulberry comprise a significant component of the current tree density and basal area, but were absent from witness tree records from the 1850s-1860s Public Land Surveys for portions of the study area in Clay, Yankton, and Union counties in South Dakota and Dixon and Cedar counties in Nebraska (Figure 4). The scarcity of native later successional species on sites established in the post-dam period and the increase of redcedar and exotic shrubs/trees in the historic floodplain may both reflect the chronic hydrologic decoupling of the historic floodplain from the river, due to flow regulation by dams and significant channel degradation. This is also suggested by the relatively low average wetland affinity score of the flora within segment 10 stands, particularly relative to segment 13 (Figure 19).

\section{Segments 8 and 9 (RM 880-841 and 841-811.1)}

Segment 8 runs from northwest to southeast, beginning at Fort Randall Dam (RM 880) and ending at the Running Water Bridge (RM 841) just downstream of the confluence with the Niobrara River. It is the upstream section (39-mile) of the Missouri River National Recreational River, administered by the National Park Service. Segment 9 is contiguous with segment 8, beginning at the Running Water Bridge (RM 841), continuing through Lewis and Clark Reservoir, and ending at Gavins Point Dam (RM 811.1).

As in segment 10, flows in segment 8 are impacted by upstream dams. Unlike segment 10, but similar to other inter-reservoir segments on the river, the lower part of segment 8 and the adjacent upper part of segment 9 are greatly influenced by the presence of the downstream Lewis and Clark Reservoir and substantial sediment inputs by the Niobrara River. Sediments from the Niobrara and other sources have contributed to delta formation, significant loss of storage capacity (>20\%) within Lewis and Clark Reservoir, and significant aggradation of the channel bed both upstream and downstream of its confluence with the Missouri. As a result, the channel bed in the upstream third (subreach 1) of segment 8 has degraded (RM 880-867), while the lower half (RM 860-841) of segment 8 and the delta area of segment 9 have significantly aggraded. Channel bed aggradation has led to significant increases in river and groundwater levels, particularly downstream from the Niobrara confluence, necessitating the relocation of the town of Niobrara, Nebraska to higher ground in 1977 (Schneiders 1999, Coker et al. 2009). Increases in stage of 6 feet (1.8 m) or more have occurred for flows of 20,000 cfs downstream of Niobrara (USACE 2004). These increases in water levels have permanently flooded areas of the floodplain, killing cottonwood and other trees and converting large areas to marsh. Most deposits in the delta area appear to be too wet to support recruitment and survival by cottonwood and other riparian forest species, although Russian olive has colonized locally higher microsites within the flooded area. 
Segment 8 is constrained by a narrower valley than segments 10 and 13, with bluffs on the Nebraska and South Dakota sides. Land cover in the valley is dominated by the river/reservoir and agricultural cropland, although the proportion composed of cropland (30\%) is much less than in segments 10 and 13 (Figure 5). Riparian forest comprises approximately $15 \%$ of the area in the valley, with wetlands (mostly in the delta) occupying $10 \%$. Very little of the area is urban, although shoreline development (cabins, etc.) is significant in some areas (e.g., Sunshine Bottoms and Verdel, Nebraska areas). Land cover in segment 9 is dominated the reservoir/river $(72 \%)$ and by wetland vegetation $(25 \%)$ in the delta and adjacent flooded mainland areas (Figure 5). Very little area of cottonwood or other riparian forest or shrub vegetation is present in segment 9 , limiting the availability of stands for vegetation sampling.

Historic changes (Figures 5, 6d) in segment 8 have been less dramatic than in segments 10 and 13, with relatively modest forest loss (16\% decline since 1892) (Figure 9). Grassland area has declined dramatically $(96 \%)$ since 1892 , with most of the loss occurring by the mid-1950s, while agricultural cropland has displayed the converse pattern. As with the segments discussed previously, the area of sandbar habitat has declined precipitously, such that it only comprises a tiny fraction of the entire landscape $(<1 \%)$. In segment 9 , nearly all $(\sim 95 \%)$ of the forest, shrubland, grassland, and agricultural cropland areas present in 1892 have disappeared, as the area has converted almost wholesale to reservoir (here not differentiated from river) and wetlands (Figures 5, 6c).

With a narrower valley and more constrained floodplain in segment 8 , the area of cottonwood shrubland and forest per river kilometer is lower than in segments 10 and 13 (Figure 13). Existing forest is dominated by the mature (50-114 year) age class $(47 \%)$, with about $67 \%$ of the forest in all from stands that established prior to dam closure (>50 years old) (Figure 11). Twenty three percent of the forest is in the $25-50$ year age range, with $10 \%$ in the $<25$ year age range (saplings and poles). Very little cottonwood shrubland and forest is present in segment 9 (Figures 12, 13), but stands <25 years old comprise $40 \%$ of the cottonwood area (Figure 11). These occur primarily in the delta area at the upstream end of the segment. The long-term fate of these sites is uncertain, given ongoing channel aggradation, delta formation, and rising water levels.

Because of the scarcity of cottonwood and other riparian forest or shrubland stands in segment 9 , only eight stands were located and sampled. Hence, our vegetation analyses lump segments 8 (where we had 54 additional stands) and 9 together. Patterns of tree species composition were generally similar to segment 10 , with American elm, green ash, eastern redcedar, box elder, hackberry, and white mulberry present in cottonwood and non-cottonwood stands over 50 years old (Figure 25a,b). Russian olive and willows were common within younger cottonwood stands. Younger noncottonwood stands (<25 years) were of two basic types, dominated by either Russian olive or by willow (S. amygdaloides, S. lutea) (Figure 25b). Across cottonwood and non-cottonwood sites, 
dominant species of shrubs (Figure 26a,b) included cottonwood, willow, and Russian olive in younger stands (esp. <25 years) and dogwood (Cornus drummondii) and redcedar in older ones (>25 years). Total shrub cover averaged lower in segment $8 / 9$ stands than segment 10 , particularly for mature and old growth stands. Overall, indices of species richness and floristic quality were somewhat lower in segment 8/9 than in segment 10 (Figures $15,17,18)$.

\section{Segment 6 (RM 1072.3-987.4)}

Segment 6 is wholly contained in South Dakota, starting at Oahe Dam, transitioning into and including Lake Sharpe, and ending at Big Bend Dam at Fort Thompson. Hence, the majority of the segment is reservoir. The upper $11 \mathrm{~km}$ (7 miles) below Oahe Dam (subreach 1) has a slightly degraded to stable channel bed (USACE 1999). At the lower end of this 11-km reach is the confluence of the Bad River with the Missouri at Fort Pierre. Sediment inputs from the Bad River and slackwater effects from Lake Sharpe have contributed to reductions in channel capacity, a bed level rise in the river, and increases in river stage just downstream of the confluence. This aggradation of the channel bed has resulted in an increased susceptibility to flooding in Fort Pierre, particularly from ice jams (USACE 1999, NRC 2002, USACE 2004). These and other factors have led to concerns that the cottonwood forests on La Framboise Island, a large forested island adjacent to the city of Pierre, are rapidly dying out (Ode 2004). Based on field reconnaissance, there appears to be a rather steep gradient of change from intact cottonwood stands at the upstream end of La Framboise Island (adjacent to Pierre, SD) to flooded areas with marsh vegetation, dead cottonwoods, and scattered Russian olive stands only a few kilometers downstream (e.g., at Farm Island). Woody riparian vegetation becomes increasingly scarce downstream and nearly absent on the reservoir, with the exception of tree plantings (some including cottonwood), wooded tributary junctions, and some Russian olive stands.

Because the bulk of segment 6 is in Lake Sharpe, river/reservoir constitutes more than $80 \%$ of the land cover in the former Missouri River floodplain (Figures 5, 6e), with minor components of grassland, forest, and urban (Pierre, Fort Pierre, Lower Brule). Historic change has resulted in the loss of approximately $65 \%$ of the forest present in 1892 (Figure 9), although forest and shrubland coverage increased sharply from 1892 to the mid-1950s (Figure 7). Sandbar area has declined dramatically, with virtually no sandbar coverage present in 2006 (Figures 5, 6e). As on segment 9, the reservoir also inundated significant areas of agricultural cropland, leading to loss of $97 \%$ of the cropland that was present in the mid-1950s within the historic floodplain.

Also as with segment 9 , the other reservoir-dominated segment, the area of cottonwood patch types per river mile is very low (about 5 hectares/river $\mathrm{km}$ ) (Figure 13), with virtually all of it in the upper 20 $\mathrm{km}$ (12 river miles) of the segment. Existing cottonwood forests are dominated by stands greater than 50 years old $(91 \%)$, with $72 \%$ in the mature (50-114 years) age class (Figure 11). Stand area 
from cohorts establishing in the last 50 years is only $9 \%$ of the total cottonwood area, with nearly all of it in the 25-50 year age class. Stands arising in the last 25 years (saplings and poles) comprise only $0.5 \%$ of the total cottonwood area, with saplings almost completely absent. Stands that have recruited in the last 25 years are generally very small and occur at unusual locations, such as in drained ponds (which may have represented intentional restoration) and a low spot in the interior of La Framboise Island. Extremely stable flow levels maintained by control of Lake Sharpe, destructive wave action along the reservoir, lack of geomorphic conditions needed to create sediment bars, and increasing water levels that drown out existing forests combine to make conditions essentially unsuitable for cottonwood recruitment along the river and reservoir. The lack of successful natural recruitment has likely provided the impetus for numerous cottonwood plantings in the area, with the area of young (<25 years old) planted stands (not included in the above total) far exceeding the area of natural cottonwood stands in that age range.

The scarcity of cottonwood stands, and of woody riparian vegetation in general over much of the segment, constrained our ability to adequately sample stands of all age classes and types. We located no cottonwood sapling stands that were of sufficient size for sampling, and only three natural pole-aged stands. Very few stands of any kind were available farther than 20-25 kilometers (12-15 miles) downstream from the dam, and those that were present were dominated by older age classes. We did, however, sample six of the sapling/pole aged planted cottonwoods stands on this segment (and four more planted stands on segment 8), although the data from these stands are not included in the summaries in this report.

Cottonwood stands on segment 6 average significantly fewer tree species per stand than segments 8/9, 10 (0.5-1 species less per stand) and 13 (2.5 species fewer) (Figure 14), and had the highest percentage of exotic tree species (1/3 of the species in a typical stand were exotics) of any segment (Figure 20). Other tree species commonly found in cottonwood stands included Russian olive and willows in younger (<25 years old) stands and green ash, redcedar, some willows and Russian olive in older (>25 year old) stands (Figure 27a). Non-cottonwood stands were dominated by Russian olive and green ash, with willows, Siberian elm (Ulmus pumila), and redcedar as well (Figure 27b). Gedars" (junipers) on this segment and possibly on the other South Dakota segments may include hybrids between eastern redcedar (Juniperus virginiana) and Rocky Mountain juniper (J. scopulorum) (Fassett 1944; Van Haverbeke 1968, cited in Ode 2004). Shrub species composition mirrored that of the dominant trees, with cottonwood, willow, Russian olive, redcedar, green ash, and Siberian elm (Figure 28a,b). Notably, roughleaf dogwood, an important shrub species in segments 8/9, 10, and 13 was only a minor component of the shrub cover in segment 6.

Overall, vegetation indicators of stand condition suggest that segment 6 has the poorest condition of all sampled study segments. Average species richness (herbs, shrubs, trees) per cottonwood stand 
was significantly lower than in all other segments except segment 13 (Figure 15), and the proportion of all species that were exotic was higher than on segments 8, 10, and 13 (Figure 16). Floristic quality, as measured by mean Coefficient of Conservatism values per stand, was dramatically lower in cottonwood stands in segment 6 than in all others, averaging 1.9 (on a 0 to 10 scale) (Figures 17, 18). Somewhat surprisingly, given the rising water levels on at least part of the segment, even the standlevel wetland affinity scores of the flora averaged lower than on all other segments (Figure 19).

\section{Segment 4 (RM 1390-1304 and 1304-1286)}

Segment 4 begins at approximately River Mile 1390 at Garrison Dam and flows south and east to just south of Bismarck, North Dakota, at approximately River Mile 1304. The Missouri River in Segment 4 is entrenched within the Missouri Plateau Section of the Great Plains Physiographic Province and flanked by four recognized terrace flights of late Pleistocene and Holocene age, which contribute to a constrained meandering planform to the river. In part because we wanted to resample stands previously surveyed by Johnson and Keammerer in 1969 and 1970 (Keammerer et al. 1975, Johnson et al. 1976), we extended the segment an additional 18 miles (29 km) downstream to River Mile 1286, for a total segment length of 104 River Miles $(167 \mathrm{~km})$. This extension (subreach 4$)$ includes areas that have been greatly impacted in the past by fluctuations in the level and extent of Lake Oahe, including channel bed aggradation, rising water levels, and mortality to cottonwood stands from flooding and fire. In addition, the portion of the segment downstream from Bismarck historically was much more geomorphically active, with higher lateral migration rates than more constrained upstream portions (Johnson et al. 1976).

As with some other inter-reservoir segments, segment 4 includes an upstream reach (RM 1389-1330) that has experienced net channel degradation (approximately $3 \mathrm{~m}$ immediately below the dam), although rates appear to have diminished in recent decades (USACE 2000, USACE 2004); a more or less stable reach (RM 1330-1310), and an aggrading reach downstream (RM 1310-1286). Our subreaches 1 (RM 1390-1360) and 2 (RM 1360-1332.5) conform roughly to the degrading reach, the upper $2 / 3$ of our subreach 3 (RM 1332.5-1310) is approximately stable, and the lower $1 / 3$ of subreach 3 (RM 1310-1304) and all of subreach 4 (RM 1304-1286) are in the aggrading reach.

Previous work by Johnson documented floodplain forest species composition (Johnson et al. 1976) and historic change, and simulated the negative effects of continuing flow regulation on cottonwood recruitment and cottonwood abundance in the landscape (Johnson 1992). His analysis of historic aerial photography, maps, and Public Land Survey notes suggested that installation and operation of Garrison Dam (in 1953) resulted in significant declines in river channel migration, leading to reduced formation of the sediment bars needed by cottonwood for successful germination and establishment. Projection of successional trends suggested that long-term flow regulation would lead to a declining 
diversity of stand ages, with a landscape dominated by older forests of late successional species (e.g., ash, elm, box elder) rather than cottonwood (Johnson 1992). Similar results to these simulation projections have been found on other meandering rivers in western North America (e.g., Rood and Mahoney 1990, Friedman et al. 1998), although braided rivers (Johnson 1994, 1998; Friedman et al. 1998), and canyon-constrained rivers (Scott et al. 1996, 1997) may show different responses to flow regulation.

Current land cover in segment 4 is dominated by forest (29\%) and agricultural cropland (25\%) (Figures $5,6 f)$. The river itself comprises $17 \%$ of the area, and grassland $(15 \%)$ and urban land uses (6\% of each) make up most of the rest of the landscape. Our analyses of historic (mid-1950s) and recent (2006) aerial photography and the Missouri River Commission maps (1892) suggest moderate changes in land cover between the 1950s and 2006, with declines in agricultural cropland (22\% decline) and forest (9\% decline), steep decreases in shrubland (-53\%) and sandbar area (-94\%), and dramatic increases in urban and grassland areas. Cumulative changes from 1892 to present were more dramatic, with a $26 \%$ decline in forest area (Figure 9), steep declines in shrubland (-74\%), and sandbar area (-96\%), and increases in agricultural cropland from $0 \%$ to $25 \%$ (32\% in the 1950 s) of the landscape (Figures 5, 6f). Hence, proportional loss of forest area on segment 4 since 1892 is comparable to that estimated on segments 8 and 13, and substantially lower than that estimated for the other inter-reservoir and reservoir segments $(2,6,9,10)$ (Figure 9).

Total cottonwood area per river kilometer is nearly 70 hectares on segment 4 , reflecting the high proportion of floodplain forest remaining in the landscape, and comparable to segments 2 and 10 (Figure 13). The age distribution of cottonwood forests on segment 4, however, is different from segments 2 and 10, with a much higher proportion of old growth (>114 years old) forest in segment 4 (42\% of the forest area), and a much lower proportion in forest less than 50 years old (15\% on segment 4, vs. 35-50\% on segments 2 and 10) (Figure 11). The proportional coverage of old growth forest is substantially greater (more than 2-fold for most) on segment 4 than any other study segment (next nearest was segment 9 with 25\%). Average hectares of younger (<50 years old) forest per river kilometer (10 hectares/km) is also substantially lower than that on segments 2 and 10 (24 and 31 hectares $/ \mathrm{km}$, respectively) (Figure 13). So, although part of the difference in cottonwood age distribution among segments may be because less of the older forest area has been lost to clearing on segment 4 , the area of new forest added (on a per river kilometer basis) has been less as well.

Plains cottonwood was dominant in cottonwood stands < 114 years old, with importance values averaging greater than 225 (out of 300 possible) (Figure 29a). In old growth (>114 years) cottonwood stands, the mean importance value of cottonwood declined to 110 , with a greater composite importance of later successional species, particularly green ash and box elder, along with minor contributions of bur oak (Quercus macrocarpa) and American elm. Species co-occurring with 
cottonwood on younger stands included Russian olive and peach-leaf willow (Salix amygdaloides). Trees in older ( $>50$ years) non-cottonwood stands (Figure $29 \mathrm{~b}$ ) were dominated almost completely by green ash and box elder, as expected in Johnson's successional model for the Garrison reach (Johnson 1992). Shrub species within mature and old growth cottonwood stands included Dahurian buckthorn (Rhamnus davurica), green ash, chokecherry (Prunus virginiana), and some Russian olive (Figure 30a). Younger cottonwood (all sapling stands, and some pole stands) stands were dominated by shrubs rather than trees, with cottonwood and willows as the dominant species. Younger non-cottonwood sites ( $<50$ years old) were dominated by shrub-sized willows ( $S$. exigua, $S$. eriocephala, $S$. lutea), with more minor contributions by green ash saplings and false wild indigo (Amorpha fruticosa) (Figure 30b). Shrub cover within older non-cottonwood stands (>50 years old) was dominated by green ash, chokecherry, and American elm (Ulmus americana). In contrast to inter-reservoir segments in South Dakota (segments 6, 8, and 10), segment 4 stands had a much lower average percentage of exotic tree species (11\% rather than $20-33 \%$ ) (Figure 20 ) and had very little cover by eastern redcedar (Juniperus virginiana).

Average stand-level species richness (overall and of herbaceous plants) and mean Coefficient of Conservatism values were high in segment 4, comparable to those found in segment 10 (Figures 15, 17, 18). Previous analyses (Dixon et al. 2009a) suggested, however, that C-values weighted by relative cover of different herbaceous species were substantially lower on segment 4 than on segment 10 , suggesting that, despite high species richness values and moderately low numbers of exotic species (Figure 16), much of the herbaceous cover within segment 4 stands may be dominated by a few exotic species or weedy species with low C-values (such as smooth brome, Bromus inermis).

Field observations suggest that successful cottonwood recruitment on much of segment 4 appears limited to channel islands and narrow, bank-edge strips of recently deposited alluvium. Ice scour and beaver herbivory are suspected to be limiting successful, longer-term survival. On the lower, extended portion of the segment below Bismarck (RM 1304-1286), where reservoir effects are strong, post-dam reservoir-induced flooding and fire appear to be important mortality factors for cottonwood forest. While direct mortality of established cottonwood forest due to flooding is likely an important mechanism, there may also be indirect effects of flooding on cottonwood mortality through interactions with fire. We conjecture that during high reservoir levels, understory vegetation - particularly grasses such as reed canary grass (Phalaris arundinacea) - may become dense and highly productive. When reservoir levels fall, the dense understory vegetation dries out and provide fuel for ground fires, which burn hotter and perhaps more frequently than would have occurred under pre-dam conditions. 


\section{Segment 2 (RM 1771.3-1543.3)}

The Segment 2 study area was defined as an approximately 228 mile segment of the Missouri River in eastern Montana, extending from Fort Peck Reservoir (RM 1771.3) to the headwaters of Lake Sakakawea near Williston, North Dakota (RM 1543.3), and including the confluence with the Yellowstone River in western North Dakota (approx. RM 1581). While we mapped the entire segment, our vegetation sampling extended only to the confluence with the Yellowstone because of the dramatic differences in conditions downstream, including more natural flows out of the unregulated Yellowstone River, significant channel aggradation (1.8-4.3 m) and a dramatic rise in stage-discharge relationships since filling of Sakakawea in 1965 (USACE 1990, USACE 2004). Bed elevation (and stage-discharge relationships) on most of the segment upstream of the Yellowstone confluence has been relatively stable over the last 35 years.

Above the confluence with the Yellowstone, the river in this segment is entrenched within the moderately rolling shortgrass steppe of eastern Montana and western North Dakota. The channel is between 244 and $366 \mathrm{~m}$ wide, set within a floodplain and low terraces that are from 3-5 km wide, and flanked by gently sloping uplands to the north and steeper bluffs on the south. Valley confinement prevents the channel from developing extensive, true meanders and several straight-channel reaches alternate with sinuous braided reaches along with confined and unconfined meanders in wider valley sections. Channel islands and numerous bars are common throughout the segment (Wei 1997). There are several minor tributaries in this reach such as the Milk River, Poplar River, and Redwater River, but their total contribution to main stem discharge is generally less than about five percent. Bank heights in this reach generally range from about 3 to $12 \mathrm{~m}$ with an average bank height of about $5.5 \mathrm{~m}$. The Yellowstone is the major tributary to the system. As described above, ecological and fluvial geomorphic conditions change at the confluence with the Yellowstone River. However, the patterns described above generally hold true for this lower portion of the segment as well, although the valley and channel are wider.

The climate in the region is semi-arid with about $350 \mathrm{~mm}$ of annual precipitation, cold winters, and hot summers. Segment 2 is set in a Great Plains Steppe landscape, sometimes called shortgrass prairie, consisting primarily of short grasses usually bunched and sparsely distributed. Grasses and herbs typical of this region include buffalo grass (Buchloë dactyloides (Nutt.) Engelm.), blue grama (Bouteloua gracilis), western wheatgrass (Agropyron smithii), and green needlegrass (Stipa viridula Trin.). Common herbs include blazingstar (Liatris spp.), sunflower species (Helianthus spp.), white prickly poppy (Argemone squarrosa Greene) and locoweed (Oxytropis spp.).

Present-day land cover (Figures 5, 6g) in the river valley is composed primarily (in descending order) of agricultural cropland $(41 \%)$, grassland $(23 \%)$, forest $(18 \%)$, the river itself $(8 \%)$, and shrubland $(7 \%)$. 
Land cover change has been moderate since the mid-1950s (Figures 5,6g), with steep declines in shrubland (-54\%) and sandbar area (-98\%) and increases by riparian forest (+31\%) (Figure 8). As with segment 10 , much of this increase in forest and loss of shrubland over the last 50 years may have been from maturation of sapling and pole stands that were mapped as shrubland in the 1950s, as the total area of woody vegetation (forest, woodland, and shrubland) decreased $12 \%$ between the 1950s and 2006 (Figure 6g). More dramatic changes occurred between the 1892 and 1950s. The Missouri River Commission maps of this segment indicate that much of the bottomland in 1892 consisted of riparian forest stands interspersed with prairie grassland at the outer edges of the floodplain. By the 1950s and 2006, many of these forest stands had been fragmented by agricultural clearing although some extensive tracts still remain, especially within the Fort Peck Indian Reservation. Much of the upland adjacent to the bottomland has also been converted to agriculture. Both grassland area and forest area (Figures 6g, 9) in the floodplain have declined since 1892 as agricultural cropland has expanded. Forest area declined 66\% between 1892 and the 1950s (Figure 7). Despite the moderate increase in forest area between the 1950s and 2006 (Figure 8), there has been a net loss of $55 \%$ of the forest area present in 1892 (Figure 9).

Segments 2, 4, and 10 had the largest areas of cottonwood patch types per river kilometer (65-68 hectares $/ \mathrm{km}$ ), compared to other segments (Figure 13). Mature forests (50-114 years) comprised 49\% of the total cottonwood area on segment 2 and old growth another 14\%. Hence, approximately $37 \%$ of the cottonwood area was composed of stands $<50$ years old, with most in the 25-50 age range $(27 \%)$ and $11 \%$ in the pole $(3 \%)$ and sapling $(8 \%)$ classes. The proportion and total area of post1950s recruitment was substantially higher on segment 2 than the inter-reservoir segments below Garrison (segment 4) and Oahe Dams (segment 6) (Figures 11-13). Age distribution of cottonwood patches within segment 2 was quite similar to that found in the comparatively free-flowing" segment in the Wild and Scenic River upstream of Fort Peck Reservoir, but total cottonwood area per river kilometer was more than 8-fold greater on segment 2, suggesting a significantly less constrained and more geomorphically dynamic river channel.

As mentioned previously, species richness of later successional tree species declined from the most downstream (segment 13) to the most upstream (segment 0) river segments (Figure 14). Cottonwood stands in segment 2 averaged 2.6 species of trees. Stands less than 50 years old were dominated by plains cottonwood and peach-leaf willow (Figure 31). Box elder and green ash occurred as successional understory trees in old cottonwood stands and dominated older successional stands (Johnson et al. 1976, Scott et al. unpublished data). In our samples, Rocky Mountain juniper (Juniperus scopulorum) was also a common species in the understory of some old growth cottonwood stands. American elm occurs sparsely on this segment, making its first appearance about mid-segment (it is not present farther upstream on segment 2, nor on segment 0), and becoming increasingly more common downstream to the confluence with the Yellowstone. 
Understory shrubs or shrubs on low, active alluvial surfaces include yellow willow (Salix lutea), sandbar willow (Salix exigua), western snowberry (Symphoricarpos occidentalis), Wood's rose (Rosa woodsii), silver buffalo berry (Shepherdia argentea), common chokecherry (Prunus virginiana), service berry (Amelanchier spp.) and rarely, red-osier dogwood (Cornus stolonifera) (Figure 32). In mature and old growth stands, saplings of green ash dominated the shrub layer, with lesser contributions of service berry and buffalo berry. Average total shrub cover was relatively low (averaged $<10 \%$ for most age classes) within our sampled stands. Overall, mean values of herbaceous and total species richness (Figure 15), floristic quality (Figures 17, 18), wetland affinity (Figure 19), and proportions of exotic species (Figure 16) are intermediate in this segment.

This reach is regulated by Fort Peck Dam, which was constructed by the US Army Corps of Engineers between 1933 and 1940. In general, the operation of Fort Peck Dam reduced the amount of sediment delivered to downstream reaches and significantly altered the natural hydrograph by decreasing the magnitude of peak flows $60-70 \%$, increasing the magnitude and variability of low flows, and shifting the timing and duration of high flows from the spring and early summer to the winter months. As a consequence, a number of important downstream physical changes have occurred, which have important ecological implications for aquatic and riparian resources. These physical changes include: 1) lowering of the channel bed elevation by an average of $1.7 \mathrm{~m}$ in a $75 \mathrm{~km}$ reach below the dam; 2) additional areas of bed degradation in reaches $70-95 \mathrm{~km}$ and $120-140 \mathrm{~km}$ below the dam; and 3) a four-fold reduction in lateral channel migration from $6.6 \mathrm{~m} / \mathrm{yr}^{-1}$ to $1.8 \mathrm{~m} / \mathrm{yr}^{-1}$ (Shields et al. 2000).

Significant public concerns in segment 2 involve channel bank erosion and associated loss of agricultural land, irrigation pumping stations and pipelines, and damage to streamside infrastructure. Specific concerns point to the significant rates of flow and flow-rate fluctuations that Fort Peck Dam imposes on the Missouri River during winter. Winter flows are much larger, and fluctuate more frequently in the post-dam period. Increased magnitudes of ice-covered flow, increased vertical ice movement along banks, and more frequent freeze-thaw cycles imposed on bank materials are seen as severely aggravating bank erosion. In contrast to the pre-dam period, bank failure now occurs primarily as a result of toe-slope scour and over-steepening by water and ice-related bank erosion (Pokrefke et al. 1998, Simon et al. 2002). Little notable bank stabilization currently exists within segment 2. However there also are concerns related to the overall possible cumulative impacts of future bank stabilization efforts on fish and wildlife resources. Such efforts could impose additional limits on natural fluvial geomorphic processes that maintain riparian and aquatic habitat - including the formation and persistence of non-vegetated sandbars, which serve as habitat for threatened and endangered bird species. 


\section{Segment 0 (RM 2073.4-1917)}

The Segment 0 (Wild and Scenic River reach) study area was defined as an approximately 156 mile (251 km) segment of the upper Missouri River extending from Fort Benton, MT (RM 2073), downstream to the full pool elevation of Fort Peck Reservoir (RM 1917). Thus, the study reach is largely contained within the Missouri Breaks National Monument and that portion of the Charles M. Russell National Wildlife Refuge above Fort Peck Reservoir. Within this portion of the upper basin, the Missouri River traverses Western Great Plains grasslands and the highly dissected topography of the Missouri Breaks. The study reach includes constrained and unconstrained channel reaches that reflect a complex geologic history (Scott and Auble 2002). From RM 2073 to 2027, the Missouri River flows within a comparatively wide drift-filled, pre-glacial valley. Channel form is meandering to braided with a number of large, in-channel islands. Cottonwood-dominated forests were more extensive in this reach as described by the Lewis and Clark expedition (Coues 1893, Scott et al. 1996), although some of these forests were cleared during settlement. From approximately RM 2027 to 1932 the river occupies a relatively narrow, post-glacial valley incised from 150 to $560 \mathrm{~m}$ below the surrounding landscape (Alden, 1932). Here, side valley exposures of shales and sandstones constrain channel movement. The channel is dominantly single-threaded, relatively straight and the majority of cottonwood forest patches are small and scattered, matching presettlement descriptions of riparian forest by the Lewis and Clark Expedition (Coues 1893). Below RM 1932, the Missouri River encounters broad exposures of easily erodible Bear Paw shale near river level, and the valley widens and the channel becomes a series of constrained meanders and larger, more continuous stands of willow and cottonwood occupy the channel point bars (Scott and Auble 2002).

This reach of the Missouri River has a snow-melt hydrograph with annual flow peaks typically occurring in May or June. The natural flow regime has been influenced by irrigation withdrawals and upstream dams. Two large upstream dams, Canyon Ferry on the Missouri River and Tiber on the Marias River, a major tributary, were constructed in 1953 and 1956 . Whereas the seasonal timing of flows have not been altered, the magnitude of peak flows has been reduced up to $40 \%$ and portions of the low flow hydrograph have increased (Scott et al. 1997, Bovee and Scott 2002). Whereas cottonwood recruitment is not strictly flood dependent, the majority of forest area $(62 \%)$ downstream of the USGS gage at Virgelle (RM 2032) was established in association with a small percentage of flood years $(29 \%)$, in which flows equaled or exceeded a discharge of $1850 \mathrm{~m}^{3} / \mathrm{sec}$ for the period of record at the Virgelle gage. Flows of this magnitude position seedlings above the zone of frequent ice-drive disturbance (Auble and Scott 1998). Ice-drive disturbance has been shown to limit or preclude the establishment of cottonwood forest patches in ice-prone reaches along northern Great Plains rivers (Smith 1980). 
Modern agricultural development within the river corridor is limited (14\% of the study area in 2006 , Figure 5) and primarily confined to old Missouri River terraces. More than half of the area of the study area is composed of the river itself $(34 \%)$ and grassland $(21 \%)$, with cropland, forest $(13 \%)$, wetlands (9\%), and shrubland (6\%) making up most of the rest of the area (Figure 5). Both the river corridor and surrounding uplands have been subject to livestock grazing since settlement in the late 1800 s, and currently includes all or parts of 55 permitted grazing areas totaling 92,848 hectares of public land (U.S. Department of the Interior 1993). However, because of a shortage of upland water sources and steep, rugged terrain between the uplands and the bottomland, livestock within the study segment are poorly distributed in most allotments and preferentially concentrate on the river flood plain where water and shade are available. Bureau of Land Management (BLM) monitoring data indicate heavy to severe utilization of the flood plain in most allotments (J. Frazier, BLM, pers. comm.). In contrast, where pastures are permitted for fall and winter grazing only or at sites inaccessible to cattle, portions of the floodplain receive less or no livestock grazing.

Recent GIS analyses comparing the 1890s Missouri River Commission maps with 2006 imagery indicate that the Missouri River channel has narrowed slightly throughout the study segment during this time interval. Coincident with this channel change have been changes in forest area that differ across the three geomorphically distinct sub-segments. In the pre-glacial valley sub-segment (RM 2073-2027) riparian forest area has increased, primarily as a consequence of the establishment of the non-native, Russian olive. Forest area in the constrained channel reach (RM 2027-1932) is limited and has remained largely unchanged as new forest area associated with channel narrowing has offset losses of older forest on higher alluvial surfaces. Forest in the sub-segment downstream of RM 1932 has decreased, primarily as a consequence of forest clearing subsequent to the 1890s (Auble and Scott unpublished data). Over the entire segment, forest area decreased slightly between 1892 and the 1950s (Figure 7), and then increased between the 1950s and present (Figure 8), for a net gain approximately 9\% from 1892-2006 (Figure 9).

Total cottonwood coverage is sparse in segment 0 , averaging only about 8 hectares per river kilometer (Figure 13), in part reflecting geologic constraints on channel migration, with small stands forming instead via overbank floods along much of the segment. Age distribution of the forest, however, is similar to that on segment 2 , with $61 \%$ of the forest area greater than 50 years old (mature $40 \%$, old growth $21 \%$ ), $30 \%$ between 25 and 50 years old, and $10 \%$ less than 25 years old (Figure 11).

Upland vegetation within the river corridor consists of relatively undisturbed prairie vegetation dominated by black greasewood, (Sarcobatus vermiculatus), big sagebrush (Artemisia tridentata) and mixed grasses including western wheat grass (Agropyron smithii), blue grama (Bouteloua gracilis), downy brome (Bromus tectorum L.), quackgrass (Agropyron repens (L.) Beauv.), green needlegrass 
(Stipa viridula Trin.), smooth brome (Bromus inermis Leyss.), and needle-and-thread (Stipa comata Trin. \& Rupr.), which occur on exposed ridges and flats. North-facing slopes contain isolated stands of Douglas fir (Pseudotsuga menziesii), ponderosa pine (Pinus ponderosa) and Rocky Mountain juniper (Juniperus scopulorum) whereas south-facing slopes contain scattered grasses, ponderosa pine or bare exposures of shale.

The principal tree species along the Missouri River was plains cottonwood. Box elder, green ash, and peach-leaf willow occurred as less common associates, particularly on islands and in former back-channels that have been filled by alluvial sediments. Russian olive was also a common associate on sampled stands $<50$ years old. Narrowleaf cottonwood (Populus angustifolia) comprised a significant component of several stands $>25$ years old and Rocky Mountain juniper was a component of some old growth cottonwood stands (Figure 33). Overall, mean tree species richness is lower (2.3 species/stand) than in any other study segment (Figure 14).

Understory shrubs on alluvial surfaces included yellow willow (Salix lutea), sandbar willow (Salix exigua), western snowberry (Symphoricarpos occidentalis), Wood's rose (Rosa woodsii), silver sagebrush (Artemisia cana), common chokecherry (Prunus virginiana), and rarely, red-osier dogwood (Cornus stolonifera) (Ross and Hunter 1976, Scott et al. 2003). Average shrub cover in our sampled stands was relatively low for all stand ages (average $<20 \%$ ), and particularly low for stands $>25$ years old (average <6\%). As in segment 2, green ash saplings were the dominant species of the shrub layer within old growth stands in segment 0 (Figure 34).

As with segment 2, stand-level species richness (overall and of herbaceous plants) and average Coefficient of Conservatism (C) values were intermediate relative to other river segments (Figures 15, 17, 18). Despite similar average C-values to other segments, however, the average percentage of the flora composed of exotic species averaged significantly higher for segment 0 stands than for any of the other segments, at nearly 40\% (Figure 16). Mean percentage of exotic species rose generally from downstream to upstream segments, with the exception of segment 6 , which had higher percent exotics than its adjacent upstream and downstream study segments.

\section{Landscape Changes and Status of Cottonwood across all Segments}

Across all segments, significant landscape changes have occurred from 1892 to present. Dramatic increases in agricultural cropland occurred on several segments (which ones), particularly between 1892 and the 1950s (Figures 5,6). In the two partially impounded segments (6 and 9), area of river/reservoir increased dramatically between the 1950s and present (Figures 5, 6c,e). Significant losses of forest, shrubland, and sandbar area occurred on most segments. Lumped across all 
segments, total forest and woodland area (excluding planted stands) declined by $34 \%$ from 18921950s, $12 \%$ from the 1950 s to 2006 , and $42 \%$ overall from 1892 to 2006 (Figure 35). Total mapped shrubland area declined 59\% over 1892-2006 and 64\% since the 1950s (shrubland area actually increased $12 \%$ between 1892 and the 1950s overall) (Figure 35). Hence, most loss of forest area occurred between 1892 and the 1950s, while most loss of shrubland area occurred between the 1950s and present. If forest, woodland, and shrubland areas are lumped, then total area of woody patch types (excluding planted trees) declined by 47\% since 1892 and 32\% since the 1950s (Figure 35). Our study segments included only two partially impounded segments (segment 6 with Lake Sharpe, segment 9 with Lewis and Clark Lake), and hence did not include the large areas of floodplain that were permanently flooded by the larger reservoirs on the system (Fort Peck, Sakakawea, and Oahe reservoirs). If these areas were included in our totals, then the loss of forest area would be dramatically greater.

Despite steep losses since the 1892 and 1950s, significant areas of woody vegetation (mostly forest) still exist (as of 2006) along the eight study segments, comprising $15.8 \%$ of the total floodplain area (including the river channel) mapped (Figures 5, 35). Across the eight study segments, we estimate that there are 75,632 ha (about 30,600 acres) of woody patch types (forest and shrubland, excluding planted trees), with $79 \%$ mapped as forest or woodland, and $21 \%$ mapped as shrubland (Figure 35). Of these, $88.3 \%$ or 66,778 ha (about 27,000 acres) were mapped as cottonwood patch types. Geographically, $66 \%$ of mapped cottonwood stand area occurred in segments $2(36 \%)$ and $13(30 \%)$, the two longest (each around 230 miles) segments (Figure 12). Other segments containing significant proportions of total cottonwood area were segment 4 (17\%), $10(9.2 \%), 8(4 \%)$ and $0(3 \%)$, with segments $6(1 \%)$ and $9(0.4 \%)$ having only very proportions of the total remaining cottonwood area.

Currently (as of 2006), stands greater than 50 years old make up the majority of the cottonwood area $(62 \%)$, with $46 \%$ of stand area in mature stands (50-114 years) and $16 \%$ in old growth (>114 years) (see Figures 11-13). Almost a quarter (24\%) of total stand area is from stands that are 25-50 years old, with only $14 \%$ for stands $<25$ years old $(6.4 \%$ for pole stands and $7.5 \%$ for saplings). So, although there appears to have been a temporary pulse of cottonwood recruitment in the aftermath of dam closure and reservoir filling on many of the segments (indicated by the relatively large proportion of stands 25-50 years old), more recent recruitment rates during the last 25 years have slowed. Similar patterns, including a temporary post-dam recruitment pulse (often accompanying channel narrowing) and subsequent recruitment declines have been observed or predicted on other regulated rivers in the Great Plains (Scott et al. 1996, Friedman et al. 1998, Johnson 1998). Following dam closure, significant channel narrowing and forest expansion often occurs on braided, sandbed rivers. However, in the absence of floods, narrowing eventually ceases and further recruitment of riparian forest slows, occurring mainly along the channel margins (Johnson 1998, Friedman and Lee 2002). 
On more strictly meandering rivers with finer sediment loads, flow regulation may lead to declines in channel migration and with it, reductions in point bar formation and cottonwood recruitment (Friedman et al. 1998; Johnson 1992, 1998). Hence, on strictly meandering rivers or river segments, there may be no, or only a minimal, post-dam narrowing phase. In our study segments, the amount of, and reasons for a recruitment pulse in the mid-1950s through 1980, varied by river segment (Figure 11-13). On some segments, this period followed or bracketed the timing of dam closure immediately upstream (segments $0,4,6,8,9,10$ ), although a post-dam recruitment pulse was not apparent on segments 4 or 6 . Despite the much earlier closure of Fort Peck Dam (1938), segment 2 also showed a proportion (27\%) of $25-50$ year old stands that was comparable to segments in which dam closure (segments 0,8 , and 10) or channelization (segment 13) occurred in the 1950s or later (Figure 11). Interestingly, segments 0 and 2, in Montana, both showed increases in forest area from the mid-1950s to present, while all other segments showed declines (Figure 8). In the case of segment 13, recruitment of new forest in the 1950s-1980 occurred largely through the construction of wing dikes designed to narrow and deepen the channel for navigation and barge traffic.

\section{CONCLUSION}

Remnant cottonwood stands along the Missouri are a valuable resource that provide habitat for a high diversity of songbirds, other wildlife species, and plants (>530 species sampled in our study). Biological diversity is sustained both through the total area of forest and also by the mosaic of different types and age classes of forest within the landscape. Despite some recruitment within the last 50 years (particularly between the 1950s and 1980), regeneration is not keeping pace with losses of cottonwoods due to land use conversions or senescence and succession under current river management regimes, as reduced rates of channel migration and sandbar formation limit opportunities for new cottonwood seedling establishment. Long-term continuation of these trends will likely result in declines in landscape diversity (e.g., declines in the mix of types and age classes of riparian forest) and reductions in the total forest area, both of which may lead to declines in floodplain biodiversity (Johnson 1992). Under continued chronically poor conditions for recruitment and only limited channel migration and bar formation, cottonwood forests in the long-term may be restricted to the immediate margins of the river channel and will gradually senesce and disappear farther away from the channel (e.g., Dixon et al. 2009b). In a sense, the large cottonwood forests remaining across much of the floodplain are a legacy of the past and could be thought of as "the living dead", currently helping support a high diversity of plants and animals, but unlikely to be replaced by regeneration in the future. Reversing this trend will require innovative thinking coupled with actions to restore or replicate the dynamic river processes that originally formed and sustained the cottonwood ecosystem. 


\section{SUGGESTIONS FOR FURTHER STUDY}

Future studies are needed to explicitly model the rates of cottonwood forest losses and to examine the conditions under which successful cottonwood recruitment could be re-initiated in the modern river. Predictive, spatially explicit modeling of current and future natural cottonwood regeneration will require linking models of cottonwood recruitment (e.g., Rood et al. 2005, Dixon and Turner 2006, Shafroth et al. 2010) with geomorphic models that realistically represent river dynamics under various flow and sediment management scenarios, climatic trends, and local reach conditions (e.g., Larsen and Greco 2002, Lancaster and Bras 2002, Richards et al. 2002, Larsen et al. 2007). We also suggest that the implications for cottonwood populations and broader ecosystem effects be considered for various flow and sediment release scenarios designed to support endangered species recovery (e.g., the spring pulse for pallid sturgeon) or other purposes (e.g., removal of sediment accumulations at the Lewis and Clark Lake delta). Finally, if planting is chosen as a tool for largescale regeneration of cottonwood forests, studies should be conducted to evaluate the degree to which planted stands replicate the diversity, structure, and ecological function found in natural cottonwood stands. 


\section{ACKNOWLEDGMENTS}

Funding for this project has been provided via contract \# W912DQ-07-C-0011 from the US Army Corps of Engineers to W. Carter Johnson, with a subcontract to Mark Dixon at the University of South Dakota (USD), and subcontracts from USD to Benedictine College (Daniel Bowen) and the USGS (Michael Scott). Dr. Gary Larson of South Dakota State University provided important assistance in plant identification, sampling, and training of vegetation sampling crews. Lisa Rabbe from the Kansas City office of the US Army Corps of Engineers has, as project manager, been instrumental in the development and implementation of this project. This project would not have been possible without her leadership and support. Caleb Caton, Rebekah Jessen, Lisa (Walters) Yager, and Adam Benson, M.S. students in the Biology Department at USD, led the field vegetation sampling and subsequent data management for segments 6, 8, 9 and 10, with able assistance from 10 undergraduate students (Adam DeZotell, Eric Dressing, Alyssa Hotz, Jennifer Young, Drew Price, Marie Chase, Andy Benson, Kyle Brewer, Cassidy Goc, Tori Collins, Tom Starzl, Emily Renner, Ming Liu, and Jesse Wolff) from USD and other institutions. Segment s 0,2 , and 4 were sampled by the USGS team under the direction of Dr. Michael L. Scott, with assistance from Elizabeth Reynolds and Dale Kohlmetz (crew leaders), and Christopher D. Peltz, Michael J. Dodrill, Lindsey Washkoviak, Brittany A. Hummel, Keir A. Morse, and Tara L. Kline. Sampling on segment 13 was supervised by Daniel Bowen, Terry Malloy, Jack Davis, and Martin Simon, with assistance from numerous undergraduate students at Benedictine College.

The GIS work was conducted at USD and USGS. Tim Cowman of the South Dakota Geological Survey and the Missouri River Institute at USD has been an important contributor to several phases of the project, including providing access to historic maps and aerial photography, scanning some of our historic imagery, providing storage space on the MRI server for our data, assisting with landowner contacts and selection of field sites, and providing advice on the GIS work. At USD, Wes Christensen and Jesse Wolf were the lead persons on most of the GIS work and were primarily responsible for the acquisition of aerial photography, photo interpretation and digitizing, production of age maps, editing and revision of the land cover and age map geodatabases, and supervision and training of undergraduate GIS assistants. Several other students at the University of South Dakota assisted with geo-rectification of images, interpretation of land cover from aerial photography and historic maps, and digitizing, including Heather Campbell, Jennifer Toribio, Adam Benson, Adam DeZotell, Eric Dressing, Alyssa Hotz, Caleb Caton, and Drew Price. Drew Price digitized the bulk of the 1890s and 2006 land cover for segment 10. Ryan Griffith was responsible for obtaining, interpreting, and entering the witness tree records from the GLO for segment 10 , and also assisted on the GIS work. At USGS, Tammy Fancher and Hanna Moyer were responsible for photo interpretation, digitizing, and analysis on segment 0 , as well as updating and editing of 2006 imagery and age class maps on segments 2 and 4. 
We want to thank numerous institutions and individuals for their assistance. Stephen K. Wilson of the Missouri National Recreational River of the National Park Service provided assistance with study site selection, GIS, permission to sample on MNRR lands, and for scientific discussions related to development of land cover classification, digitizing protocols, and other themes. Theresa Smydra, USDA Natural Resources Conservation Service and Missouri River Futures, provided assistance on land owner contacts and site access. Ed Rodriguez and Michael Bryant of the US Fish and Wildlife Service at Karl Mundt and Lake Andes National Wildlife refuges provided access to sampling sites on Karl Mundt NWR and housing to our field crew during our sampling of segment 8 in 2007 . Clarence Montgomery and the Yankton Sioux Tribe provided access to tribal lands on segment 8 . Northern Prairies Land Trust, Farmers National, Chris Miller, and other individuals and other groups provided access to private lands on segments 8 and 10. Dave Ode and Dan McCormick of the South Dakota Department of Game, Fish, and Parks assisted us with study site selection, site access contacts, tree cores, and additional information on segment 6. Shaun Grassel of the Lower Brule Sioux Tribe provided housing during field work on segment 6 . Joel Bich of the Lower Brule Sioux Tribe provided information and access to some tribal lands on segment 6 for sampling.. We would like to acknowledge additional support from the following institutions and individuals for work on segments 0 , 2, and 4: The Missouri-Yellowstone Confluence Interpretive Center, North Dakota State Historical Society, Williston, North Dakota; Deb Madison, Fort Peck Indian Reservation, Poplar, Montana; Eric Lang, Cross Ranch State Park, Center, North Dakota; Fort Abraham Lincoln State Park, Mandan, North Dakota; and Chad Krause, Bureau of Land Management, Lewistown Field Office, Lewistown, Montana.

Finally, we wish to thank the numerous private landowners, across all of our study segments, who graciously entrusted us with access to their property for our sampling. 


\section{LITERATURE CITED}

Alden, W. C. 1932. Physiography and glacial geology of eastern Montana and adjacent areas. U.S. Geological Survey professional paper 174. U.S. Government Printing Office, Washington, D.C.

Auble, G. T., and M. L. Scott. 1998. Fluvial disturbance patches and cottonwood recruitment along the upper Missouri River, Montana. Wetlands 18:546-556.

Bovee, K. D., and M. L. Scott. 2002. Effects of flow regulation on the upper Missouri River: implications for flood pulse restoration. Regulated Rivers: Research and Management 18:287-298.

Bragg, T., and A. Tatschl. 1977. Changes in flood-plain vegetation and land use along the Missouri River from 1826 to 1972. Environmental Management 1(4): 343-348.

Coker, E.H., R.H. Hotchkiss, and D.A. Johnson. 2009. Conversion of a Missouri River dam and reservoir to a sustainable system: sediment management (1). Journal of the American Water Resources Association 45:815-827.

Coues, E. 1893. The history of the Lewis and Clark expedition. Volume 1. E. Coues, editor. Francis P. Harper, New York. (Unabridged republication by Dover Publications, New York.)

Cottam, G. and J. T. Curtis. 1956. The use of distance measures in phytosociological sampling. Ecology 37:451-460.

Dabhdouh-Guebas, F. and N. Koedam. 2006. Empirical estimate of the reliability of the use of the point-centered quarter method (PCQM): Solutions to ambiguous field situations and description of the PCQM+ protocol. Forest Ecology and Management 228:1-18.

Dixon, M.D., W.C. Johnson, M.L. Scott, and D. Bowen. 2009a. 2008 Annual Report - Missouri River Cottonwood Study. Annual Report to the Army Corps of Engineers, Contract \# W912DQ-07-C-0011.

Dixon, M. D., J. C. Stromberg, J. T. Price, H. Galbraith, A. K. Fremier, and E. W. Larsen. 2009b. Potential effects of climate change on the upper San Pedro riparian ecosystem. Chapter 3, In: Stromberg, J. C. and B. Tellman (eds.), Ecology and Conservation of the San Pedro River. University of Arizona Press, Tucson, AZ.

Dixon, M. D., and M. G. Turner. 2006. Simulated recruitment of riparian trees and shrubs under natural and regulated flow regimes on the Wisconsin River. River Research and Applications 22(10):1057-1083.

Fassett, N.C. 1944. Juniperus virginiana, J. horizontalis and J. scopulorum - II. Hybrid swarms of J. virginiana and J. scopulorum. Bulletin of the Torrey Botanical Club 71:475-483 (cited in Ode 2004).

Friedman, J.M. and V.J. Lee. 2002. Extreme floods, channel change, and riparian forests along ephemeral streams. Ecological Monographs 72(3):409-425.Friedman, J.M., W.R. Osterkamp, M.L. Scott, and G.T. Auble. 1998. Downstream effects of dams on channel geometry and bottomland vegetation: regional patterns in the Great Plains. Wetlands 
18:619-633.

Galat, D.L. and R. Lipkin. 2000. Restoring the ecological integrity of great rivers: historical hydrographs aid in defining reference conditions for the Missouri River hydrosystem. Hydrobiologia 422/423:29-48.

Gentry DJ, D.L. Swanson, and J.D. Carlisle. 2006. Species richness and nesting success of migrant forest birds in natural river corridors and anthropogenic woodlands in southeastern South Dakota. The Condor 108:140-153.

Hesse, L.W., C.W. Wolfe, and N.K. Cole. 1988. Some aspects of energy flow in the Missouri River ecosystem and a rationale for recovery. In N.G. Benson (ed.), The Missouri River, The Resources, Their Uses, and Values. North Central Division, American Fisheries Society.

Jacobson, R.B., D.W. Blevins, and C.J. Bitner. 2009. Sediment regime constraints on river restoration-An example from the Lower Missouri River. In: James, L.A., S.L. Rathburn, and G.R. Whittecar (eds.), Management and Restoration of Fluvial Systems with Broad Historical Changes and Human Impacts: Geological Society of America Special Paper 451:1-22

Johnson, W. C. 1992. Dams and riparian forests: case study from the upper Missouri River. Rivers $3(4): 229-242$

Johnson, W.C. 1998. Adjustment of riparian vegetation to river regulation in the Great Plains, U.S.A. Wetlands 18:608-618.

Johnson, W.C. 2002. Riparian vegetation diversity along regulated rivers: contribution of novel and relict habitats. Freshwater Biology 47: 749-759.

Johnson, W. C., R. L. Burgess, and W. R. Keammerer. 1976. Forest overstory and environment along the Missouri River in North Dakota. Ecological Monographs 46:59-84.

Johnson, W. C., G.E. Larson, and M. D. Dixon. 2006. Cottonwood forests of the Missouri National Recreational River: their measurement and ecological health. Final report to the Army Corps of Engineers, Project CENWK-PM-PR.

Keammerer, W. R., W. C. Johnson, and R. L. Burgess. 1975. Floristic analysis of the Missouri River bottomland forests in North Dakota. Can. Field-Naturalist 89:5-19.

Ladd, D. 1997. Coefficients of conservatism for Missouri vascular flora. Unpublished report. The Nature Conservancy. St. Louis, MO. 53 pp.

Lancaster, S.T. and R.L. Bras. 2002. A simple model of river meandering and its comparison to natural channels. Hydrological Processes 16:1-26.

Larsen, E.W., E.H. Girvetz and A.K. Fremier. 2007. Landscape level planning in alluvial riparian floodplain ecosystems: Using geomorphic modeling to avoid conflicts between human infrastructure and habitat conservation. Landscape and Urban Planning 79(3-4):338-346.

Larsen, E.W. and S.E. Greco. 2002. Modeling Channel Management Impacts on River Migration: A Case Study of Woodson Bridge State Recreation Area, Sacramento River, California, USA. Environmental Management 30(2):209-224. 
Lesica, P. and P. Husby. 2001. Field Guide to Montana's Wetland Vascular Plants. Montana Wetlands Trust, Helena, Montana. $96 \mathrm{pp}$. http://nris.state.mt.us/wis/wetlands/metadata.html

Lindsey, A. A. 1955. Testing the line-strip method against full tallies in diverse forest types. Ecology 36:485-494.

Miller, J.R., T.T. Schulz, N.T. Hobbs, K.R. Wilson, D.L. Schrupp, and W.L. Baker. 1995. Changes in the landscape structure of a southeastern Wyoming riparian zone following shifts in stream dynamics. Biological Conservation 72:371-379.

National Research Council Panel. 2002. The Missouri River Ecosystem: Exploring the Prospects for Recovery. National Academy Press, Washington, DC. 175 pp.

The Northern Great Plains Floristic Quality Assessment Panel. 2001. Coefficients of conservatism for the vascular flora of the Dakotas and adjacent grasslands. U.S. Geological Survey, Biological Resources Division, Information and Technology Report USGS/BRD/ITR-2001-0001. 32 pp. http://www.npwrc.usgs.gov/resource/plants/fga/index.htm

Ode, D.J. 2004. Wildlife habitats of LaFramboise Island: vegetational change and management of a Missouri River island. Wildlife Division Report No. 2004-14. South Dakota Game, Fish and Parks Department.

Pokrefke, T.J., Abraham, D.A., Hoffman, P.H., Thomas, W.A., Darby, S.E. \& Thorne, C.R. (1998) Cumulative erosion impacts analysis for the Missouri River master water control manual review and update study. Technical Report No. CHL-98-7, Vicksburg, MS, USA: US Army Engineer Waterways Experiment Station: 288 pp.

Reed, P. B., Jr. 1988. National list of plant species that occur in wetlands: national summary. U. S. Fish and Wildlife Service Biological Report 88(24). 244 pp.

Richards, K., J. Brasington, and F. Hughes. 2002. Geomorphic dynamics of floodplains: ecological implications and a potential modelling strategy. Freshwater Biology 47(4):559-579.

Rolfsmeier, S., and G. Steinauer, 2003. Vascular plants of Nebraska (Ver. I). Nebraska Natural Heritage Program. Nebraska Game and Fish Commission, Lincoln, NE.

Rood S.B. and J. M. Mahoney. 1990. Collapse of riparian poplar forests downstream from dams in western prairies: probable causes and prospects for mitigation. Environmental Manag ement, 14:451-464.

Rood, S.B., G.M. Samuelson, J.H. Braatne, C.R. Gourley, F.M.R. Hughes, J.M. Mahoney. 2005. Managing river flows to restore floodplain forests. Frontiers in Ecology and the Environment 3(4):193-201.

Ross, R. L., and H. E. Hunter. 1976. Climax vegetation of Montana based on soil and climate. U.S. Department of Agriculture Soil Conservation Service, Bozeman, Montana.

Scott, M. L., J. M. Friedman, and G. T. Auble. 1996. Fluvial process and the establishment of bottomland trees. Geomorphology 14:327-339.

Scott, M.L., G.T. Auble, and J.M. Friedman, J.M. 1997. Flood dependency of cottonwood 
establishment along the Missouri River, Montana, USA. Ecological Applications 7(2): 677-90.

Scott, M. L., and G.T. Auble. 2002. Conservation and restoration of semiarid riparian forests: a case study from the upper Missouri River, Montana. Pages 145-190 in B. A. Middleton, editor. Flood pulsing in wetlands: Restoring the natural hydrological balance. John Wiley \& Sons, New York.

Scott, M.L., Skagen, S.K., and Merigliano, M.F. 2003. Relating geomorphic change and grazing to avian communities in riparian forests. Conservation Biology 17: 284-296.

Schneiders, R.K. 1999. Unruly River. Two Centuries of Change along the Missouri. University Press of Kansas. 314 pp.

Shafroth, P.B., A.C. Wilcox, D.A. Lytle, J.T. Hickey, D.C. Andersen, V.B. Beauchamp, A. Hautzinger, L.E. McMullen, and A. Warner. 2010. Ecosystem effects of environmental flows: modelling and experimental floods in a dryland river. Freshwater Biology 55(1):68-85.

Shields, D.F., Simon, A., and L.J. Steffen. 2000. Reservoir effects on downstream river channel migration. Environmental Conservation 27 (1): 54-66.

Simon, A., Thomas, R.E., Curini, A, Shields, D.F Jr. 2002. Case Study: Channel Stability of the Missouri River, Eastern Montana. Journal of Hydraulic Engineering 128: 880-890.

Smith, D. 1980. River ice processes: thresholds and geomorphic effects in northern and mountain rivers. Pages 323-343 in D. R. Coats and J. D. Vitek, editors. Thresholds in geomorphology. Allen and Unwin, Boston.

Stromberg, J. C., R. Tiller and B. Richter. 1996. Effects of groundwater decline on riparian vegetation of semiarid regions: the San Pedro River, Arizona, USA. Ecological Applications 6:113-131.

Swink, F. A. and G. S. Wilhelm. 1994. Plants of the Chicago region. Fourth Edition. Indiana Academy of Sciences, Indianapolis. 921 pp.

Taft, J., G. Wilhelm, D. Ladd, and L. Masters. 1997. Floristic quality assessment for vegetation in Illinois. A method for assessing vegetation integrity. Eriginia 15(1):3-95

Thogmartin, W.E, M. Gallagher, N. Young, J.J. Rohweder, and M.G. Knutson. 2009. Factors associated with succession of abandoned agricultural lands along the lower Missouri River, U.S.A. Restoration Ecology 17:290-296.

USACE (US Army Corps of Engineers). 2004. Missouri River Stage Trends. RCC Technical Report A-04. Reservoir Control Center, U.S. Army Corps of Engineers, Northwestern Division - Missouri River Basin, Omaha, Nebraska.

USACE (US Army Corps of Engineers). 2000. Garrison Project - Downstream Channel and Sediment Trend Study Update. MRD Sediment Memorandum \#16A, March 2000.

USACE (US Army Corps of Engineers). 1999. Missouri River Oahe Dam to Big Bend Dam Aggradation Assessment. MRD Sediment Memorandum \#22.

USACE (US Army Corps of Engineers). 1990. Lake Sakakawea Headwaters Aggradation Study, Sept. 1990. 
USDA, NRCS. 2008. The PLANTS Database (http://plants.usda.gov, 15 January 2008). National Plant Data Center, Baton Rouge, LA 70874-4490 USA.

US Department of the Interior. 1993. Upper Missouri national wild and scenic river management plan update. Bureau of Land Management, Lewistown, Montana.

Van Haverbeke, D.F. 1968. A population analysis of Juniperus on the Missouri River Basin. University of Nebraska Studies: New Series No. 38. 81 pp. (cited in Ode 2004)

Wei, T.C. 1997. Downstream channel and sediment trends study. Unpublished report, US Army Corps of Engineers, Omaha, NE, USA: Midwest International Inc.: 55 pp.

WEST Consultants, Inc. 2002. Missouri River Gavins Point Dam degradation trends study. Prepared for U.S. Army Corps of Engineers, Omaha District, Contract DACW45-01-D-0003, Task Order Number 0013. 
Table 1. Description of study segments and number of stands sampled per segment. Numbers of stands of cottonwood, disturbed cottonwood, and noncottonwood that are $<25$ years old (sapling and pole) are indicated in parentheses.

\begin{tabular}{|c|c|c|c|c|c|c|c|c|}
\hline Segment & Description & $\begin{array}{l}\text { River } \\
\text { Miles }\end{array}$ & Type of Segment & $\begin{array}{l}\text { Total } \\
\text { Stands }\end{array}$ & Cottonwood & $\begin{array}{l}\text { Disturbed } \\
\text { Cottonwood }\end{array}$ & $\begin{array}{l}\text { Non- } \\
\text { cottonwood }\end{array}$ & $\begin{array}{c}\text { Planted } \\
\text { Cottonwood }\end{array}$ \\
\hline 0 & $\begin{array}{l}\text { Wild and Scenic reach, } \\
\text { Fort Benton to Fort Peck } \\
\text { Reservoir }\end{array}$ & $\begin{array}{l}2073.4- \\
1917\end{array}$ & Free-flowing (FF) & 29 & $29(11)$ & 0 & 0 & \\
\hline 2 & $\begin{array}{l}\text { Fort Peck Dam to Lake } \\
\text { Sakakawea }\end{array}$ & $\begin{array}{l}1771.3- \\
1543.3\end{array}$ & Inter-reservoir (IR) & 30 & $30(12)$ & 0 & 0 & \\
\hline 4 & $\begin{array}{l}\text { Garrison Dam to Lake } \\
\text { Oahe }\end{array}$ & $\begin{array}{l}1390- \\
1286\end{array}$ & Inter-reservoir (IR) & 66 & $35(12)$ & $10(0)$ & $21(5)$ & \\
\hline 6 & $\begin{array}{l}\text { Oahe Dam to Big Bend } \\
\text { Dam (includes Lake } \\
\text { Sharpe) }\end{array}$ & $\begin{array}{l}1072.3- \\
987.4\end{array}$ & $\begin{array}{l}\text { Inter-reservoir (IR)/ } \\
\text { Reservoirs and } \\
\text { Headwaters (R\&H) }\end{array}$ & 38 & $17(3)$ & $4(0)$ & $11(2)$ & $6(6)$ \\
\hline 8 & $\begin{array}{l}\text { Fort Randall Dam to } \\
\text { Springfield, SD }\end{array}$ & $880-841$ & Inter-reservoir (IR) & 54 & $33(12)$ & $4(0)$ & $13(6)$ & $4(2)$ \\
\hline 9 & $\begin{array}{l}\text { Springfield, SD to Gavins } \\
\text { Point Dam (includes } \\
\text { Lewis \& Clark Reservoir) }\end{array}$ & $\begin{array}{l}841- \\
811.1\end{array}$ & $\begin{array}{c}\text { Reservoirs \& } \\
\text { Headwaters (R\&H) }\end{array}$ & 8 & $7(4)$ & $1(0)$ & 0 & \\
\hline 10 & $\begin{array}{l}\text { Gavins Point Dam to } \\
\text { Ponca, Nebraska }\end{array}$ & $\begin{array}{l}811.1- \\
753\end{array}$ & Unchannelized (UC) & 59 & $34(11)$ & $7(2)$ & $18(5)$ & \\
\hline 13 & $\begin{array}{l}\text { Plattsmouth, Nebraska to } \\
\text { Kansas City }\end{array}$ & $\begin{array}{l}365.5- \\
595.5\end{array}$ & Channelized (C) & 48 & $31(15)$ & $6(1)$ & $11(5)$ & \\
\hline & TOTAL & & & 332 & $216(80)$ & $32(3)$ & $74(23)$ & $10(8)$ \\
\hline
\end{tabular}


Table 2. Land cover categories used for GIS mapping of 2006 land cover.

\section{Water/bare sandbar}

11. River main channel (open water, sand, submersed aquatic vegetation)

12. Oxbow lake/backwater - off channel or connected

13. Unvegetated sandbar

14. Farm ponds, other open water habitats

15. Missouri River reservoir

16. Tributary river channel

17. Constructed sandbar (emergent sandbar habitat)

18. Unvegetated sandbar in tributary

2. Forest and woodland (forest has woody plants $>6 \mathrm{~m}$ tall with $>50 \%$ cover; woodland has woody plants $>6 \mathrm{~m}$ tall with $25-50 \%$ cover)

20. non-cottonwood (cottonwood $<15 \%$ ) floodplain forest

21. forest (cottonwood at least 15\%)

22. woodland (cottonwood at least $15 \%$ )

23. planted trees (farm woodlots, shelterbelts, orchards)

24. upland forest (not in floodplain)

25. non-cottonwood (cottonwood $<15 \%$ ) woodland

27. planted cottonwood trees

3. Shrubland - woody plants $<6 \mathrm{~m}$ tall account for $25-100 \%$ of cover

30. shrubland (with cottonwood)

31. non-cottonwood shrubland

\section{Low vegetation - Herbaceous or woody}

41. upland grassland, pasture

42. riparian low shrub with cottonwood (successional sandbar sites, may include a mixture of low woody and herbaceous vegetation)

43. emergent wetland (off river)

44. riparian low herbaceous vegetation

45. riparian low shrub w/o cottonwood

46. wet meadow / mesic grassland

\section{Planted/cultivated - row crops}

50. agricultural row crops 


\section{Developed/urban}

61. Town, city (e.g., Vermillion)

62. Farmstead and building complex (excluding woodlots)

63. Commercial/Industrial/Transportation (roads, parking lots, boat landings)

64. Urban/recreational grasses (developed right-of-ways, golf courses)

65. Cabin or managed cottonwood areas

7. Barren - bare sand, etc. (not in river channel, but could include island interior) 70. barren

8. Other - specify in notes

80. other, disturbed

81. other, abandoned agriculture

9. Areas inundated by filling reservoir (1950s for segment 9 only)

91. flooded forest

92. flooded open area (probably agricultural cropland) 


\section{FIGURE CAPTIONS}

Figure 1. Map of Missouri River basin, indicating study segment locations. Priority bald eagle segments shown in red and other study segments indicated with blue text. Modified from graphic obtained from U.S. Army Corps of Engineers. Original source unknown.

Figure 2. Historic land cover change on segment 10 (Gavins Point Dam to Ponca, Nebraska) based on GIS analysis of 1892 Missouri River Commission maps and aerial photography from 1955-56, 1983-85, and 2006/2008. Pink in 1892 map indicates undefined land cover in 1892 Missouri River Commission maps.

Figure 3. Draft cottonwood age class map, overlaid on 2006 aerial imagery for Vermillion, S.D. vicinity on segment 10 . Pink areas are sapling (<10 year old) stands, red are pole (10-25 years old), yellow are intermediate (25-50 years old), green are mature (50-114 years old) and blue are old growth (>114) stands.

Figure 4. Relative density and basal area of different tree species from the witness tree records of the General Land Office Survey for segment 10 (Gavins Point Dam to Ponca, NE) vs. 2007 field data (weighted by relative area of different age classes) within cottonwood stands on segments 8 and 10 . Note the increases in relative abundance of red cedar, Russian olive, and white mulberry from the 1850 s to present, and the decrease in elm and willow. Increases in red cedar may signify, in part, the effects of flow regulation and channel incision that have disconnected the vegetation of the historic floodplain from flooding. Russian olive and white mulberry are exotic species that were unlikely to have been present in the 1850s in the region. Declines in elm relative abundance are likely related to the impacts of Dutch Elm Disease.

Figure 5. Relative area of different land cover classes, by study segment and image year. Greatest change occurred for most segments in 1892-1950s, with expansion of agriculture. Greatest changes from 1950s to 2006 occurred on segments with reservoirs (segments 6 and 9), with steep declines in most other cover types. General trends across most segments included increases in agricultural cropland and declines in forest, shrubland, grassland, and sandbar.

Figure 6a. Historic changes in relative coverage of major land cover classes, on segment 13 (channelized segment between Plattsmouth, NE and Kansas City, MO).

Figure 6b. Historic changes in relative coverage of major land cover classes on segment 10 (Gavins Point Dam to Ponca, NE). Note that data include land cover from 1983/84 as well.

Figure 6c. Historic changes in relative coverage of major land cover classes on segment 9 (downstream of Niobrara delta to Gavins Point Dam, including Lewis and Clark Reservoir. River" category includes reservoir.

Figure 6d. Historic changes in relative coverage of major land cover classes on segment 8 (Fort Randall Dam to downstream of Niobrara delta).

Figure 6e. Historic changes in relative coverage of major land cover classes on segment 6 (Oahe Dam to Big Bend Dam, including Lake Sharpe). As with Figure 4c, river" category includes reservoir.

Figure 6f. Historic changes in relative coverage of major land cover classes on segment 4 (Garrison Dam to upper reaches of Lake Oahe, including Bismarck area).

Figure 6g. Historic changes in relative coverage of major land cover classes on segment 2 (Fort Peck Dam to upper reaches of Sakakawea Reservoir near Williston, ND).

Figure 6h. Historic changes in relative coverage of major land cover classes on segment 0 (Wild and Scenic River reach, Fort Benton to upper reaches of Fort Peck Reservoir).

Figure 7. Percentage change in total forest area per study segment from 1892 through the mid1950s. Most forest declines were related to agricultural conversion. 
Figure 8. Percentage change in total forest area per study segment from mid-1950s through 2006. Largest declines $(>80 \%)$ are on the two segments with reservoirs - segments 6 (includes Lake Sharpe) and 9 (includes Lewis and Clark Reservoir), while forest area actually increased on the two most upstream segments (0 and 2 ) in Montana and western North Dakota.

Figure 9. Percentage change in total forest area per study segment from 1892 through 2006 . Total forest area includes both cottonwood and non-cottonwood types. The only segment without a decline is the relatively free-flowing Wild and Scenic segment (segment 0), upstream of Fort Peck reservoir in Montana.

Figure 10. Net land cover conversions to or from forest in segment 10 from 1956 and 1984 to 2006. Dominant mode of forest loss was conversion to agricultural cropland, while dominant mode of forest gain was via maturation of shrubs or saplings to forest.

Figure 11. Relative area of different cottonwood age classes on each study segment. Lowest proportion of forest $<50$ years old occurs on segments 4 (below Garrison) and 6 (below Oahe), signifying little new recruitment of cottonwood forest since dam closure on/upstream of those segments.

Figure 12. Total cottonwood area (hectares), by age class, on each study segment.

Figure 13. Mean cottonwood area (hectares) per river kilometer, by age class, on each study segment. Lowest areas per river kilometer were on two segments with reservoirs (segments 6 and 9) and the relatively free-flowing, but geologically-constrained, Wild and Scenic River segment (segment $0)$ in Montana.

Figure 14. Adjusted mean ( \pm standard error) overall shrub-layer and tree species richness for cottonwood stands (disturbed stands excluded) across Missouri River study segments. Average number of tree species (particularly for later successional species) declines progressively from most downstream (13) to farthest upstream (0) study segments.

Figure 15. Adjusted mean ( \pm standard error) overall stand and herb-layer plant species richness for cottonwood stands (disturbed stands excluded) across Missouri River study segments. Cottonwood stands with the highest mean number of all species and herbaceous species were in segments 4 (below Garrison) and 10 (below Gavins Point).

Figure 16. Adjusted mean \% ( \pm standard error) of plant species (all layers) that are non-native for cottonwood stands (disturbed stands excluded) across Missouri River study segments. As shown above, proportion of exotic species generally increased from downstream to upstream, with the exception of the heavily modified segment 6 (Oahe Dam to Big Bend Dam), which had higher proportions of exotic species than the next segments upstream and downstream.

Figure 17. Overall stand (all layers) adjusted mean ( \pm standard error) Coefficient of Conservatism values for cottonwood stands (disturbed stands excluded) across Missouri River study segments. Highest average C-values were in segments 4 (below Garrison) and 10 (below Gavins Point), signifying highest floristic quality on those sites, with the lowest values (signifying low floristic quality) in segment 6 (Oahe Dam to Big Bend Dam).

Figure 18. Adjusted mean ( \pm standard error) Coefficient of Conservatism values for the herb-layer, shrub-layer, and overstory (trees) in cottonwood stands (disturbed stands excluded) across Missouri River study segments.

Figure 19. Adjusted mean ( \pm standard error) Wetland score $(1=$ UPL, $2=\mathrm{FACU}, 3=\mathrm{FAC}, 4=$ FACW, $5=\mathrm{OBL}$ ) of plant species within cottonwood stands (disturbed stands excluded) across study segments. Higher values in segment 13 (channelized segment between Plattsmouth, NE and Kansas City, MO) suggest a higher prevalence of wetland species in the flora, which may reflect more frequent flooding (including sampling season in 2008) on that segment than the others. 
Figure 20. Adjusted mean \% ( \pm standard error) of tree species that are non-native for cottonwood stands (disturbed stands excluded) across Missouri River study segments. Highest percentages of exotic tree species occur on the South Dakota segments $(6,8 / 9$, and 10$)$.

Figure 21a. Relative importance value (sum of relative frequency, density, and basal area) of different tree species by cottonwood forest age class in segment 13. Data for $>114$ years old age class were from a single stand.

Figure 21b. Relative importance value (sum of relative frequency, density, and basal area) of different tree species within disturbed cottonwood and non-cottonwood forests in segment 13 . DCW refers to disturbed cottonwood stands and NCW refers to non-cottonwood stands. Data for DCW $<25$, DCW 25-50, NCW<25, and NCW 25-50 were from single stands of each type.

Figure 22a. Mean percent shrub cover by different species and overall mean shrub cover by cottonwood forest age class in segment 13. Estimates of total shrub cover may be inflated because of overlapping cover of different species along the transect segments. Data for $>114$ years old age class were from a single stand.

Figure 22b. Mean percent shrub cover by different species and overall mean shrub cover within non-cottonwood and disturbed cottonwood forests in segment 13. Estimates of total shrub cover may be inflated because of overlapping cover of different species along the transect segments. DCW refers to disturbed cottonwood stands and NCW refers to non-cottonwood stands. Data for DCW $<25$, DCW 25-50, and NCW 25-50 were from single stands of each type.

Figure 23a. Relative importance value (sum of relative frequency, density, and basal area) of different tree species by cottonwood forest age class in segment 10.

Figure 23b. Relative importance value (sum of relative frequency, density, and basal area) of different tree species within disturbed cottonwood and non-cottonwood forests in segment 10 . DCW refers to disturbed cottonwood stands and NCW refers to non-cottonwood stands. Data for DCW 2550 and NCW $<25$ were from single stands of each type.

Figure 24a. Mean percent shrub cover by different species and overall mean shrub cover by cottonwood forest age class in segment 10. Estimates of total shrub cover may be inflated because of overlapping cover of different species along the transect segments.

Figure 24b. Mean percent shrub cover by different species and overall mean shrub cover within non-cottonwood and disturbed cottonwood forests in segment 10. Estimates of total shrub cover may be inflated because of overlapping cover of different species along the transect segments. DCW refers to disturbed cottonwood stands and NCW refers to non-cottonwood stands. Data for DCW 25-50 were from a single stand.

Figure 25a. Relative importance value (sum of relative frequency, density, and basal area) of different tree species by cottonwood forest age class in segments 8 and 9 . Data for $<10$ years old age class were from a single stand.

Figure 25b. Relative importance value (sum of relative frequency, density, and basal area) of different tree species within disturbed cottonwood and non-cottonwood forests in segments 8 and 9 . DCW refers to disturbed cottonwood stands and NCW refers to non-cottonwood stands. Data for DCW 25-50 and NCW 25-50 were from single stands of each type.

Figure 26a. Mean percent shrub cover by different species and overall mean shrub cover by cottonwood forest age class in segments 8 and 9 . Estimates of total shrub cover may be inflated because of overlapping cover of different species along the transect segments.

Figure 26b. Mean percent shrub cover by different species and overall mean shrub cover within non-cottonwood and disturbed cottonwood forests in segment 8 and 9 . Estimates of total shrub cover may be inflated because of overlapping cover of different species along the transect segments. DCW refers to disturbed cottonwood stands and NCW refers to non-cottonwood stands. Data for DCW 25-50 and NCW 25-50 were from single stands of each type. 
Figure 27a. Relative importance value (sum of relative frequency, density, and basal area) of different tree species by cottonwood forest age class in segment 6 . No cottonwood stands $<10$ years old were located that were of sufficient size for sampling.

Figure 27b. Relative importance value (sum of relative frequency, density, and basal area) of different tree species within disturbed cottonwood and non-cottonwood forests in segment 6 . DCW refers to disturbed cottonwood stands and NCW refers to non-cottonwood stands. Data for DCW 2550 were based on a single stand.

Figure 28a. Mean percent shrub cover by different species and overall mean shrub cover by cottonwood forest age class in segment 6 . Estimates of total shrub cover may be inflated because of overlapping cover of different species along the transect segments. No cottonwood stands $<10$ years old were located that were of sufficient size for sampling.

Figure 28b. Mean percent shrub cover by different species and overall mean shrub cover within non-cottonwood and disturbed cottonwood forests in segment 6 . Estimates of total shrub cover may be inflated because of overlapping cover of different species along the transect segments. DCW refers to disturbed cottonwood stands and NCW refers to non-cottonwood stands. Data for DCW 2550 were based on a single stand.

Figure 29a. Relative importance value (sum of relative frequency, density, and basal area) of different tree species by cottonwood forest age class in segment 4 . Sampled cottonwood stands $<10$ years old did not have any trees (stems $>10 \mathrm{~cm} \mathrm{dbh}$ ).

Figure 29b. Relative importance value (sum of relative frequency, density, and basal area) of different tree species within disturbed cottonwood and non-cottonwood forests in segment 4 . DCW refers to disturbed cottonwood stands and NCW refers to non-cottonwood stands. Sampled NCW sites $<25$ and $25-50$ years old did not have any trees (stems $>10 \mathrm{~cm} \mathrm{dbh}$ ).

Figure 30a. Mean percent shrub cover by different species and overall mean shrub cover by cottonwood forest age class in segment 4 . Estimates of total shrub cover may be inflated because of overlapping cover of different species along the transect segments.

Figure 30b. Mean percent shrub cover by different species and overall mean shrub cover within non-cottonwood and disturbed cottonwood forests in segment 4. Estimates of total shrub cover may be inflated because of overlapping cover of different species along the transect segments. DCW refers to disturbed cottonwood stands and NCW refers to non-cottonwood stands. Data for NCW 2550 were based on a single stand.

Figure 31. Relative importance value (sum of relative frequency, density, and basal area) of different tree species by cottonwood forest age class in segment 2 . Sampled cottonwood stands $<10$ years old did not have any trees (stems $>10 \mathrm{~cm} \mathrm{dbh}$ ).

Figure 32. Mean percent shrub cover by different species and overall mean shrub cover by cottonwood forest age class in segment 2. Estimates of total shrub cover may be inflated because of overlapping cover of different species along the transect segments.

Figure 33. Relative importance value (sum of relative frequency, density, and basal area) of different tree species by cottonwood forest age class in segment 0 . Sampled cottonwood stands $<10$ years old did not have any trees (stems $>10 \mathrm{~cm} \mathrm{dbh}$ ).

Figure 34. Mean percent shrub cover by different species and overall mean shrub cover by cottonwood forest age class in segment 0 . Estimates of total shrub cover may be inflated because of overlapping cover of different species along the transect segments.

Figure 35. Composite changes in forest and shrubland area across all study segments from 1892 to the mid-1950s to 2006. Total area of natural woody vegetation declined $47 \%$ from 1892 to 2006 , with a $42 \%$ decline in forest and a $59 \%$ decline in shrubland. Note that most forest loss occurred between 1892 and the 1950s, while most shrubland loss occurred between the 1950s and 2006. 


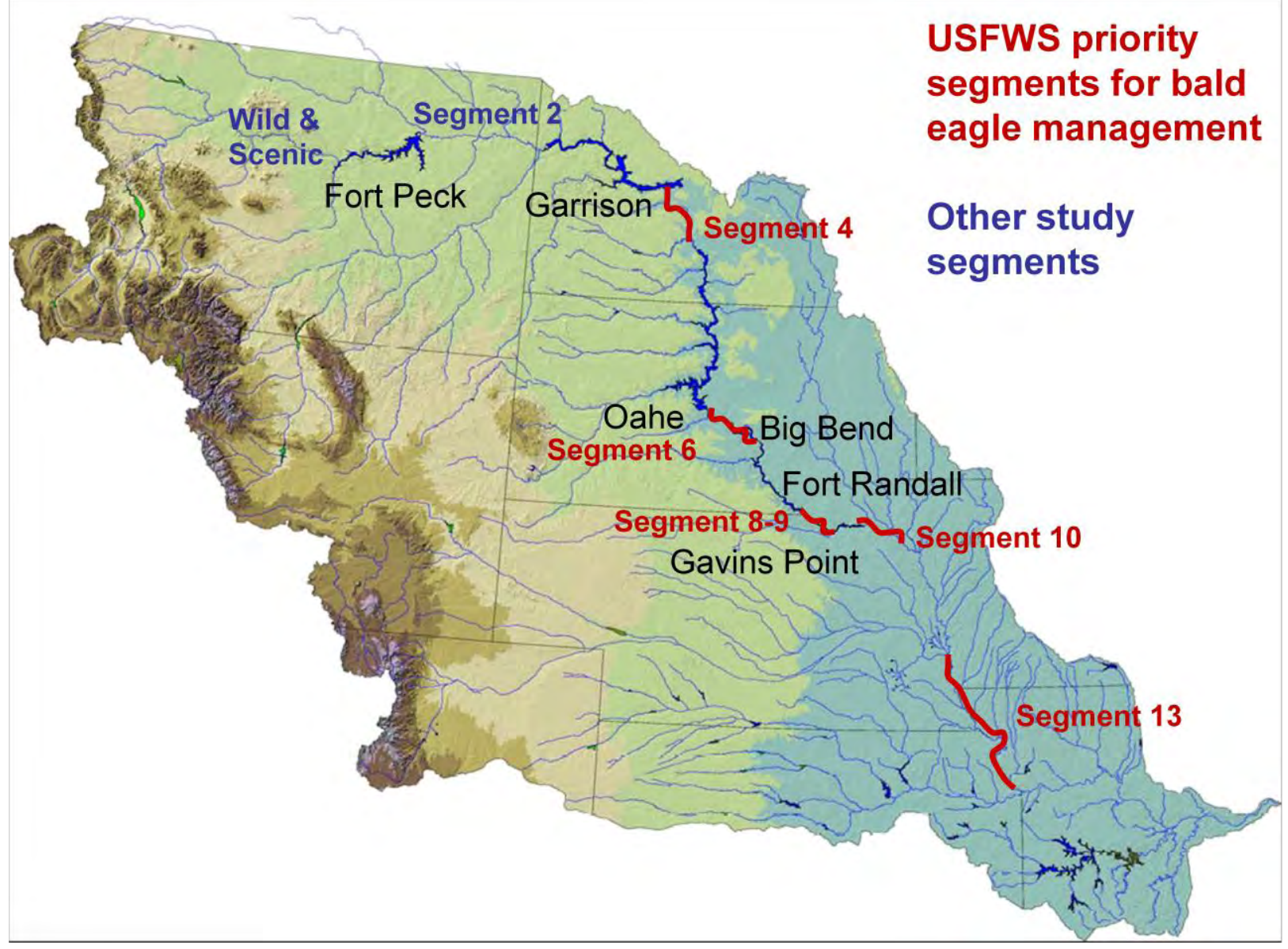

Figure 1. Map of Missouri River basin, indicating study segment locations. Priority bald eagle segments shown in red and other study segments indicated with blue text. Modified from graphic obtained from U.S. Army Corps of Engineers. Original source unknown. 


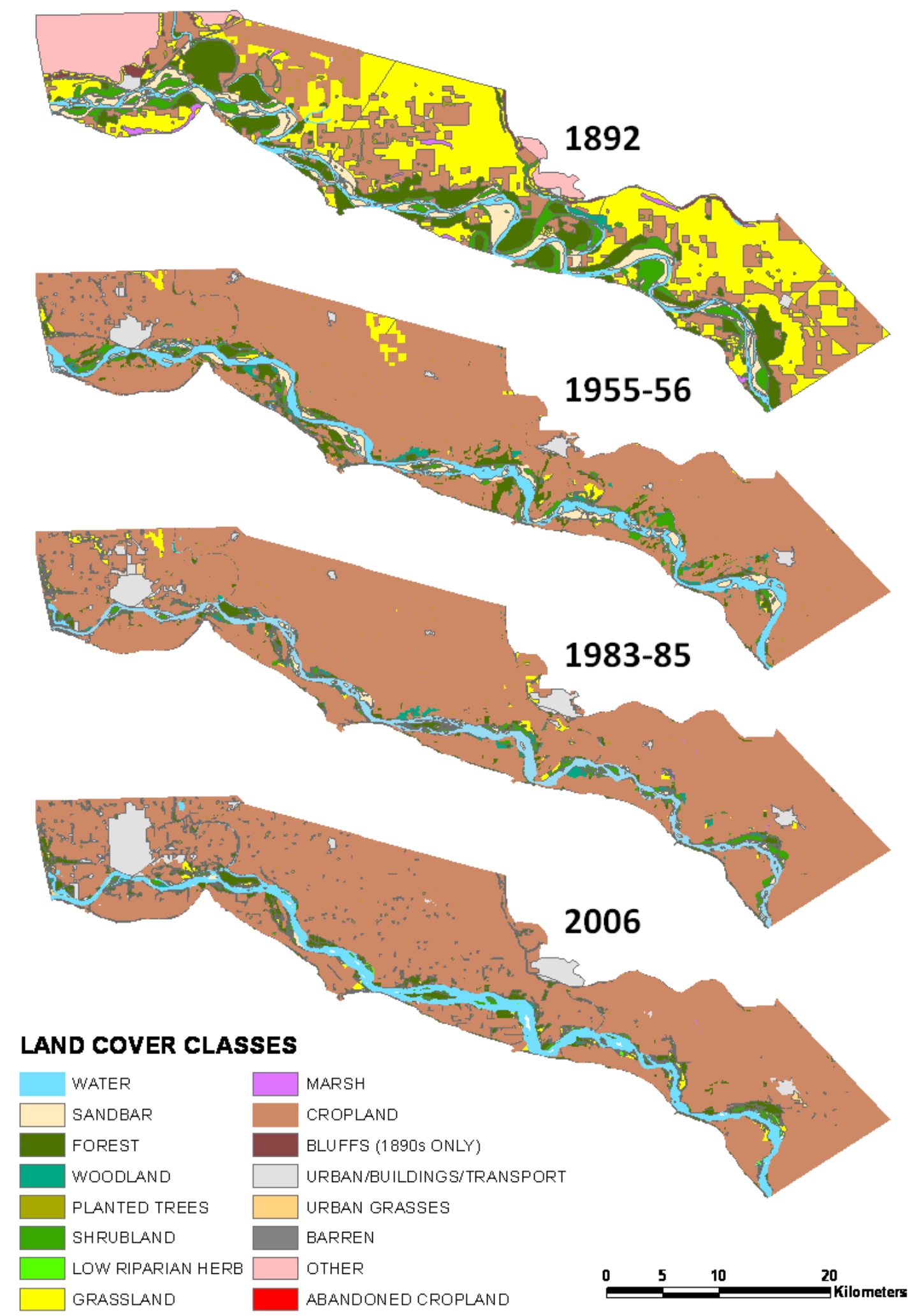

Figure 2. Historic land cover change on segment 10 (Gavins Point Dam to Ponca, Nebraska) based on GIS analysis of 1892 Missouri River Commission maps and aerial photography from 1955-56, 1983-85, and 2006. Pink in 1892 map indicates undefined land cover in 1892 Missouri River Commission maps. 


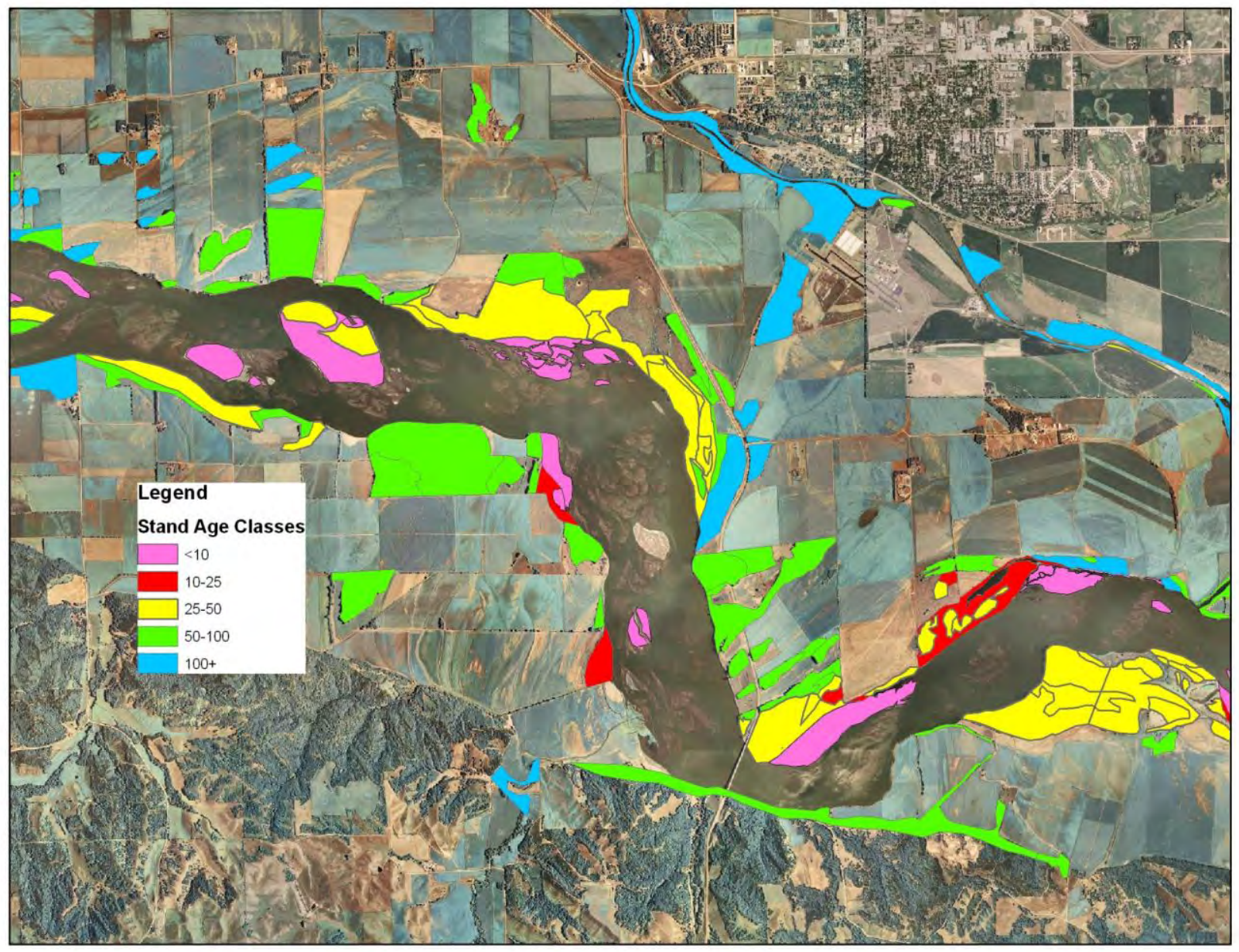

Figure 3. Draft cottonwood age class map, overlaid on 2006 aerial imagery for Vermillion, S.D. vicinity on segment 10 . Pink areas are sapling (<10 year old) stands, red are pole (10-25 years old), yellow are intermediate (25-50 years old), green are mature (50-114 years old) and blue are old growth (>114) stands. 


\section{Relative Density}
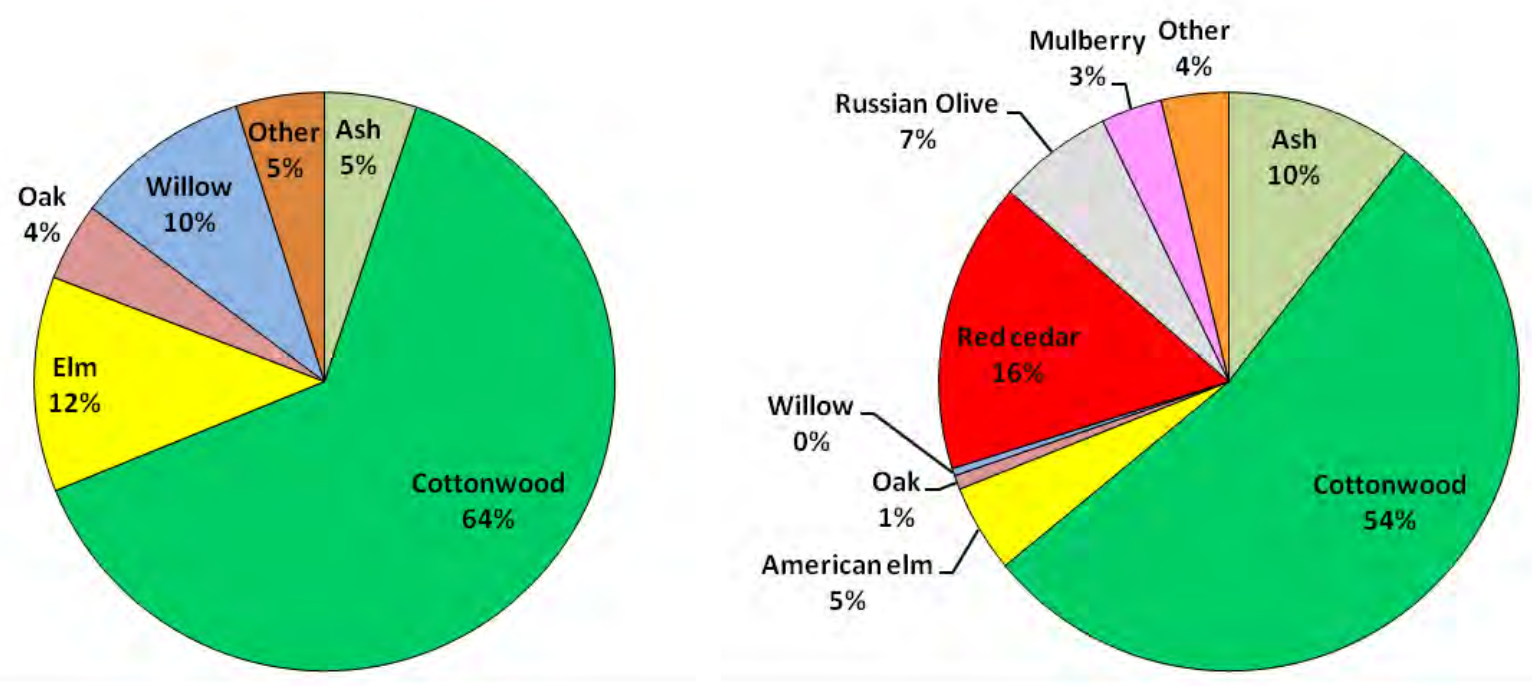

\section{Relative Basal Area}

1857-1869 (GLO Survey, segment 10)

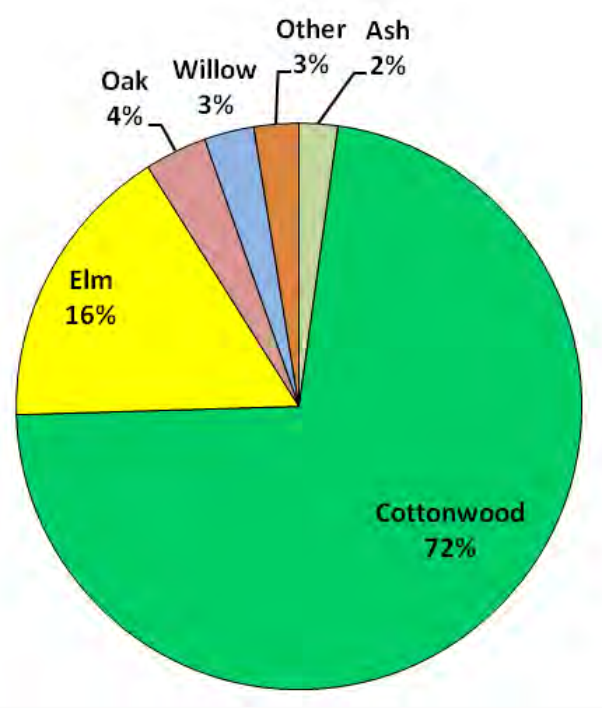

2007 Field Data (segments 8 and 10)

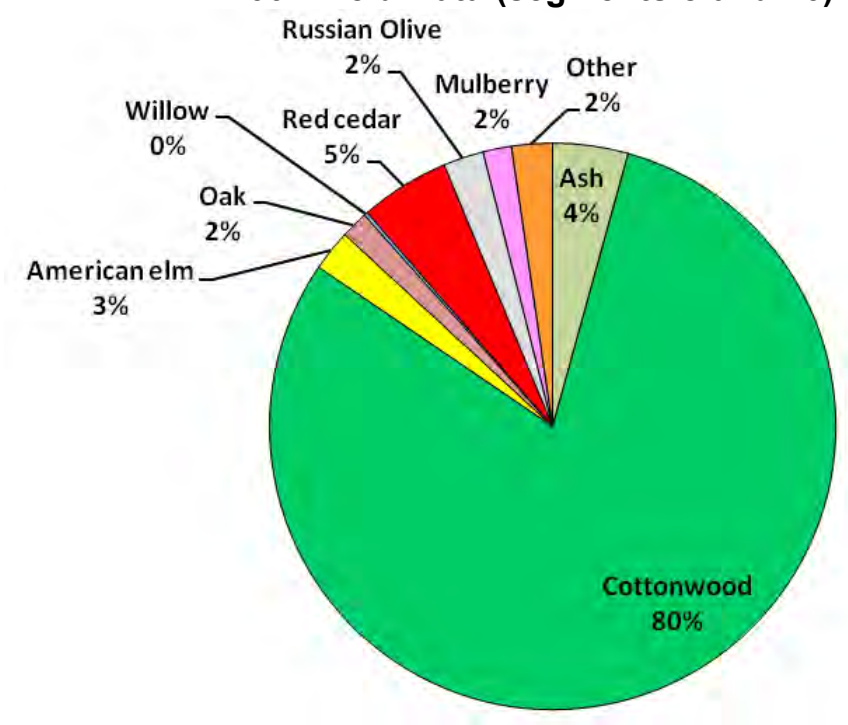

Figure 4. Relative density and basal area of different tree species from the witness tree records of the General Land Office Survey for segment 10 (Gavins Point Dam to Ponca, NE) vs. 2007 field data (weighted by relative area of different age classes) within cottonwood stands on segments 8 and 10 . Note the increases in relative abundance of red cedar, Russian olive, and white mulberry from the 1850 s to present, and the decrease in elm and willow. Increases in red cedar may signify, in part, the effects of flow regulation and channel incision that have disconnected the vegetation of the historic floodplain from flooding. Russian olive and white mulberry are exotic species that were unlikely to have been present in the 1850s in the region. Declines in elm relative abundance are likely related to the impacts of Dutch Elm Disease. 

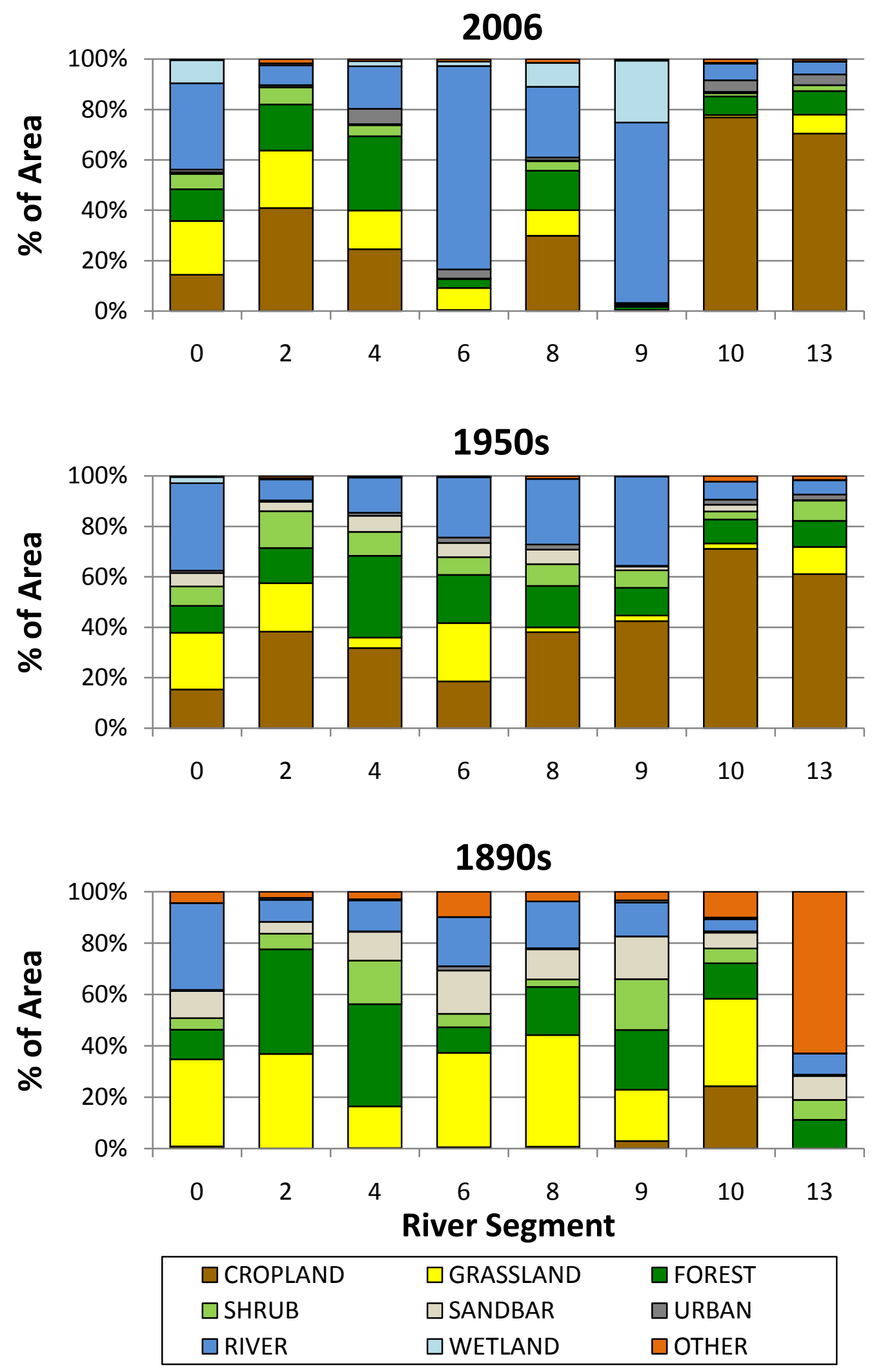

Figure 5. Relative area of different land cover classes, by study segment and image year. Greatest change occurred for most segments in 1892-1950s, with expansion of agriculture. Greatest changes from 1950s to 2006 occurred on segments with reservoirs (segments 6 and 9), with steep declines in most other cover types. General trends across most segments included increases in agricultural cropland and declines in forest, shrubland, grassland, and sandbar. 


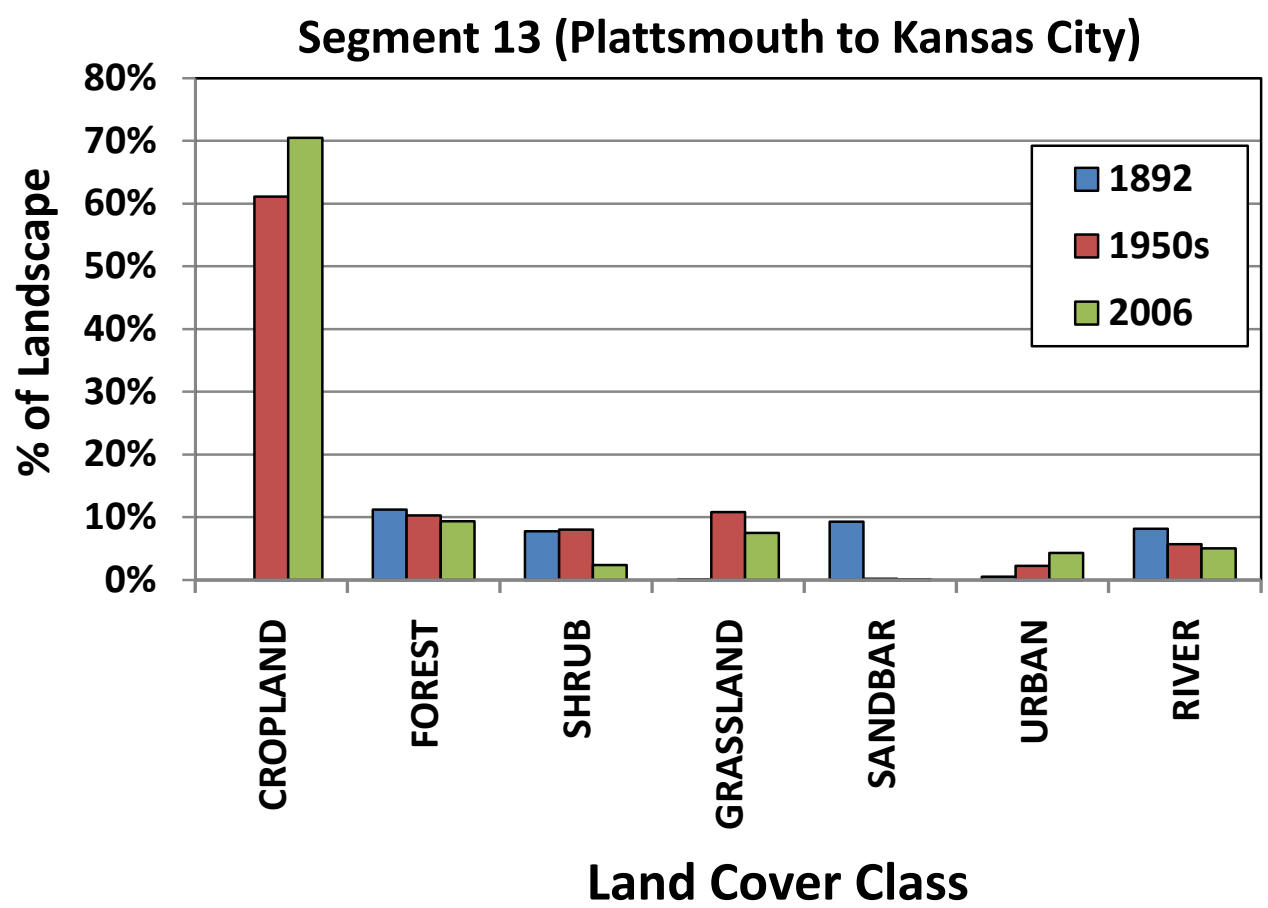

Figure 6a. Historic changes in relative coverage of major land cover classes, on segment 13 (channelized segment between Plattsmouth, NE and Kansas City, MO).

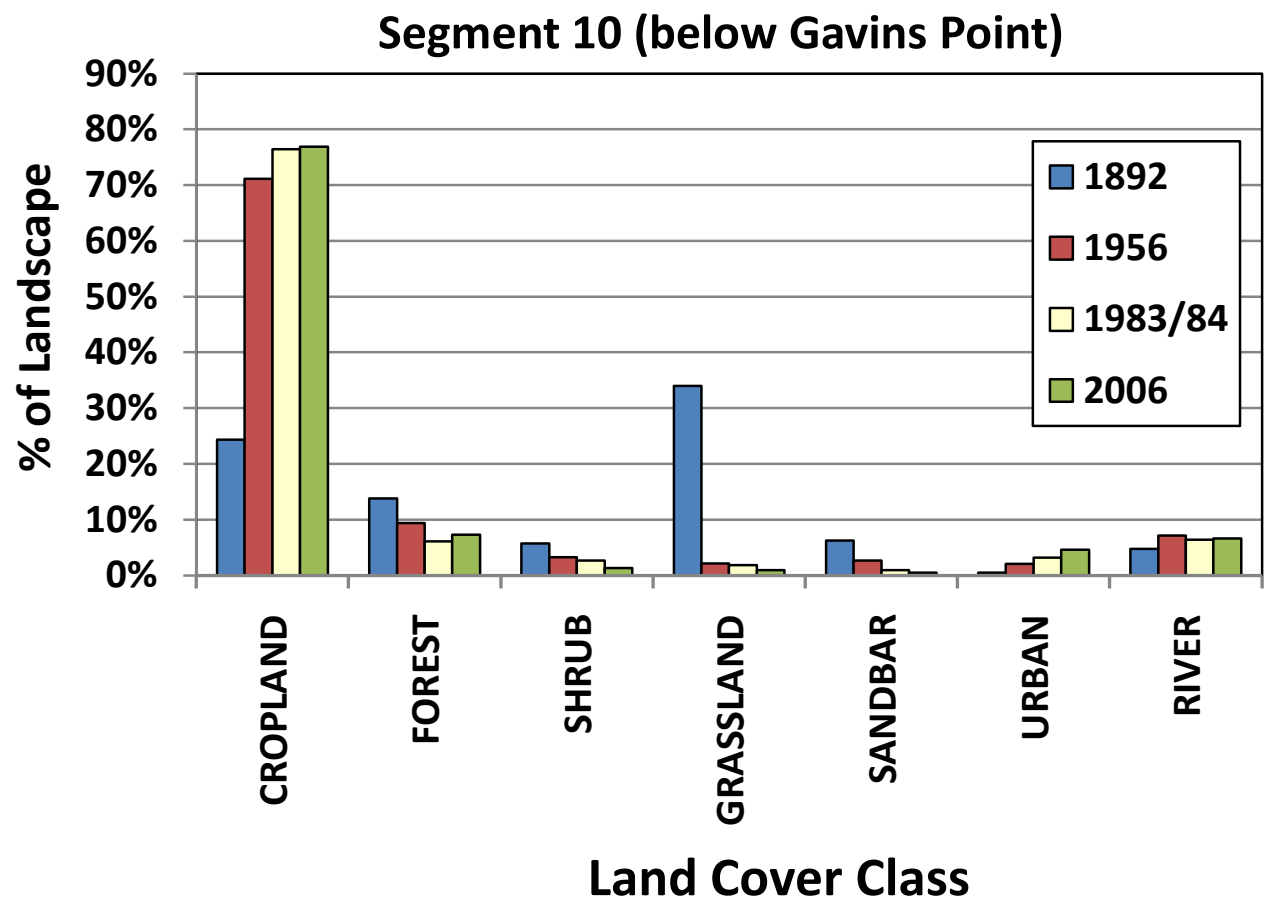

Figure 6b. Historic changes in relative coverage of major land cover classes on segment 10 (Gavins Point Dam to Ponca, NE). Note that data include land cover from 1983/84 as well. 


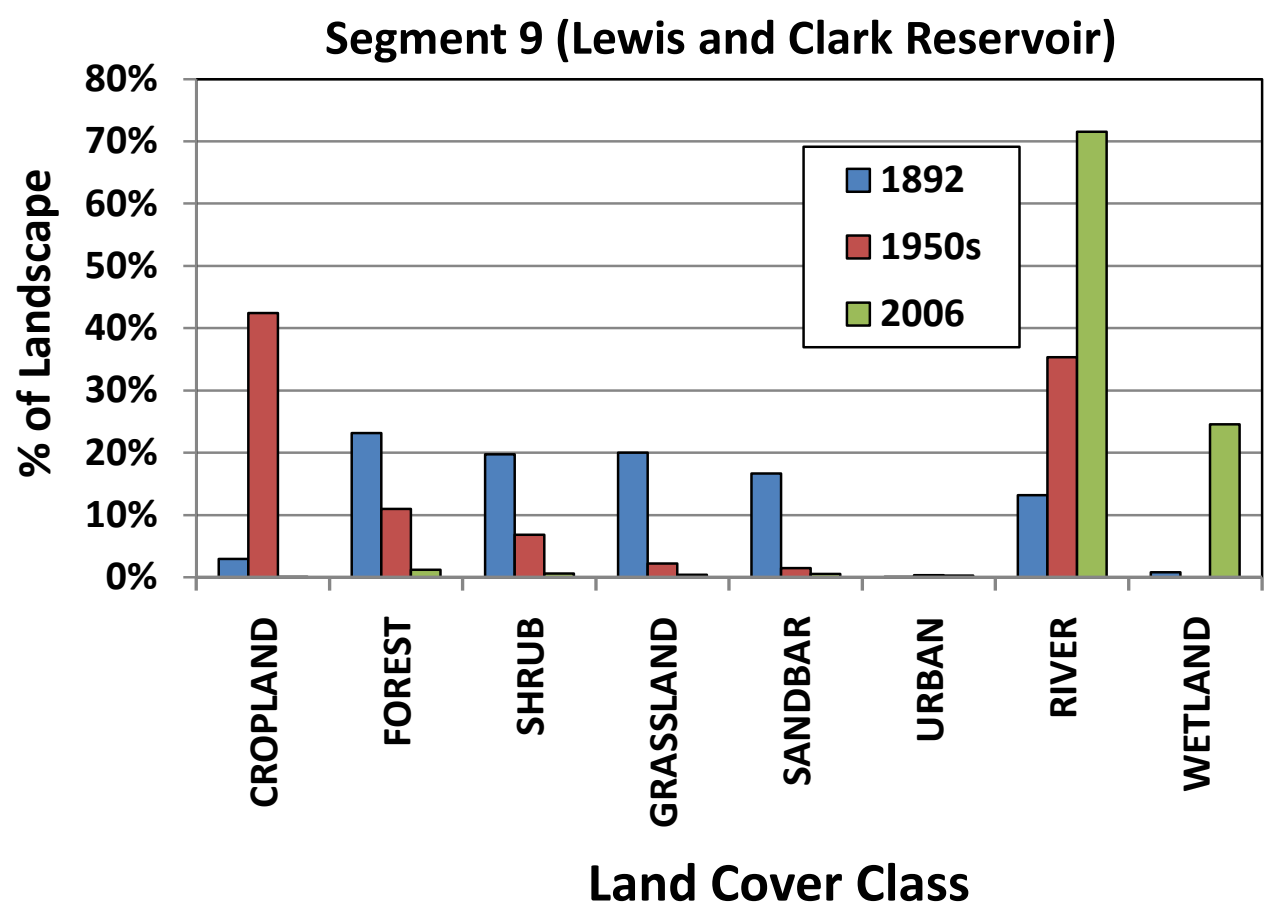

Figure 6c. Historic changes in relative coverage of major land cover classes on segment 9 (downstream of Niobrara delta to Gavins Point Dam, including Lewis and Clark Reservoir. River" category includes reservoir.

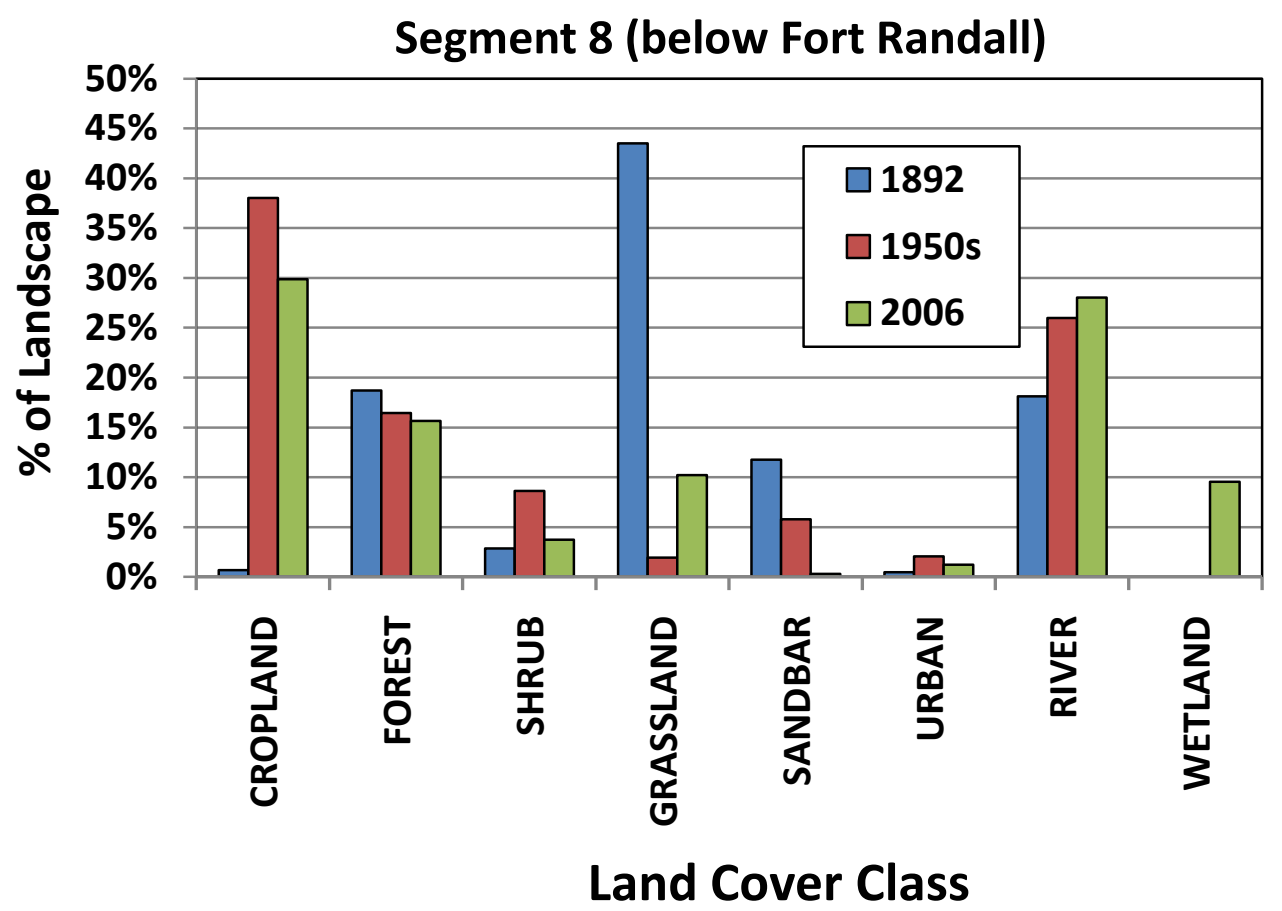

Figure 6d. Historic changes in relative coverage of major land cover classes on segment 8 (Fort Randall Dam to downstream of Niobrara delta). 


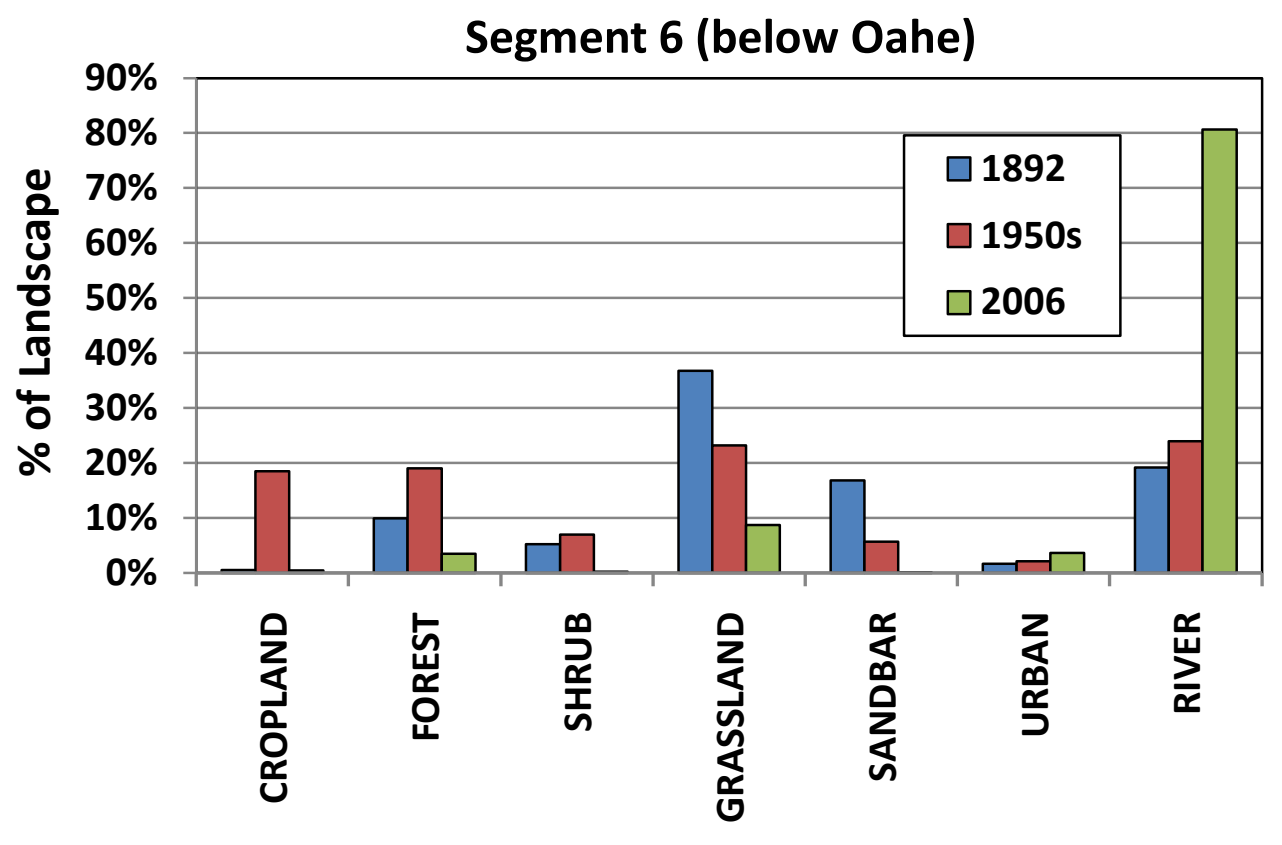

Land Cover Class

Figure 6e. Historic changes in relative coverage of major land cover classes on segment 6 (Oahe Dam to Big Bend Dam, including Lake Sharpe). As with Figure 4c, river" category includes reservoir.

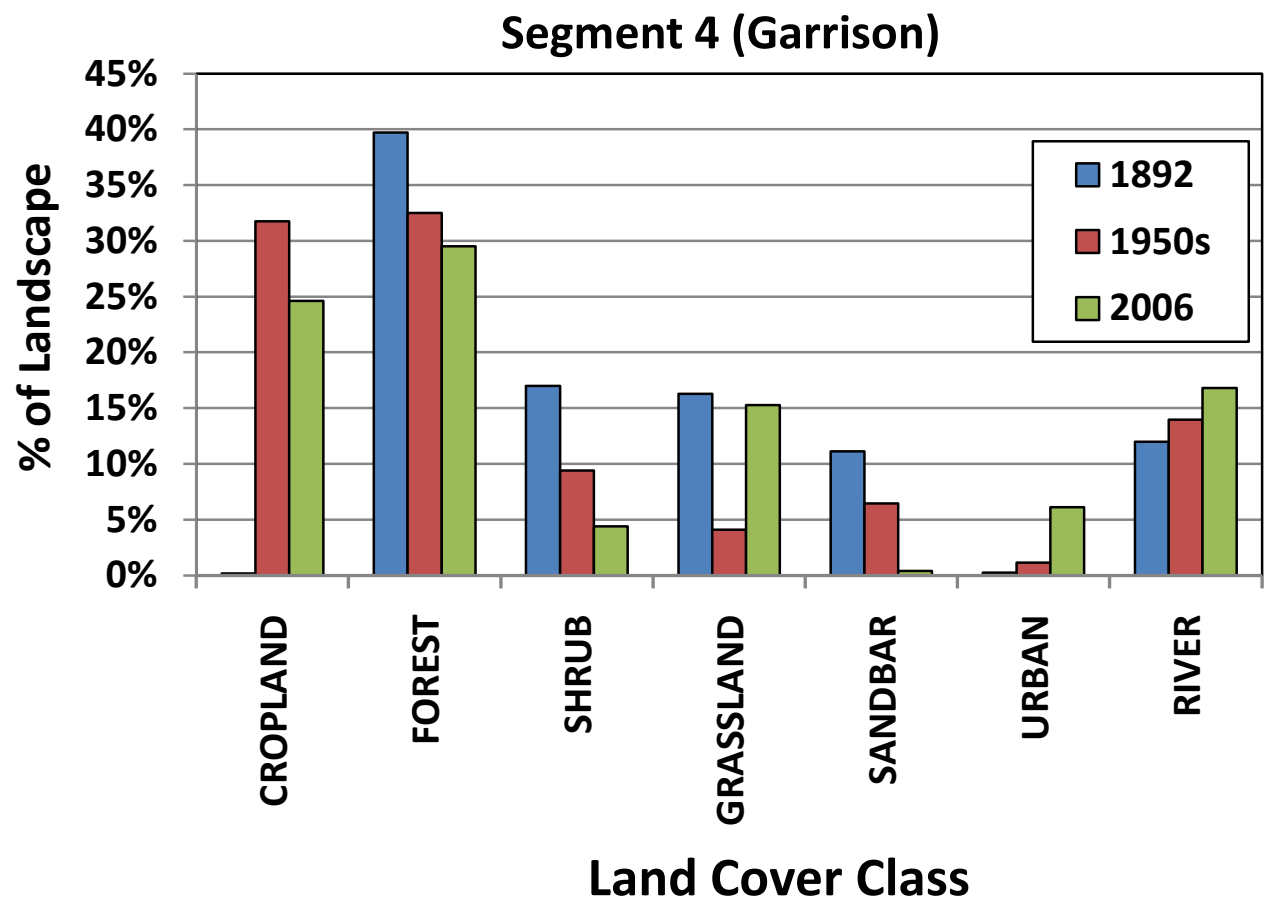

Figure 6f. Historic changes in relative coverage of major land cover classes on segment 4 (Garrison Dam to upper reaches of Lake Oahe, including Bismarck area). 


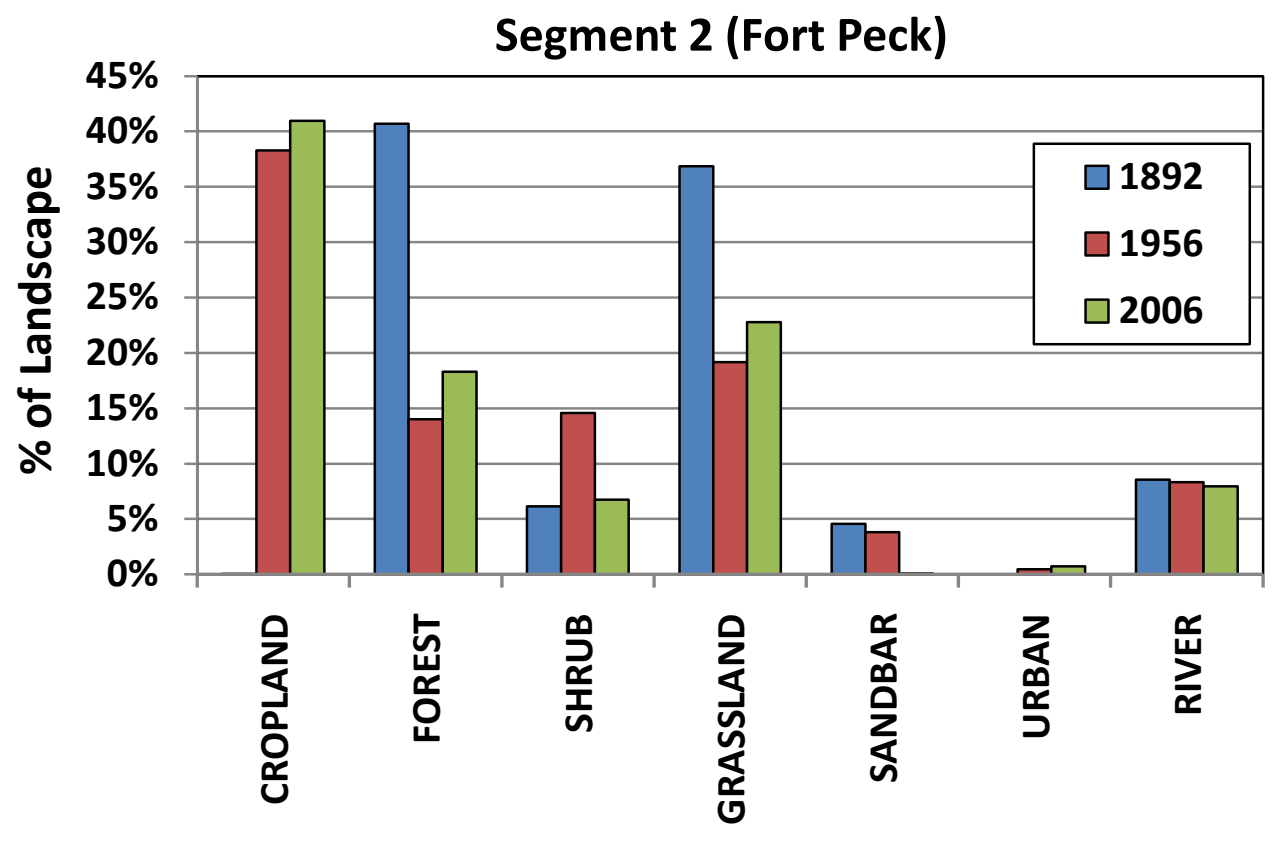

Land Cover Class

Figure 6g. Historic changes in relative coverage of major land cover classes on segment 2 (Fort Peck Dam to upper reaches of Sakakawea Reservoir near Williston, ND).

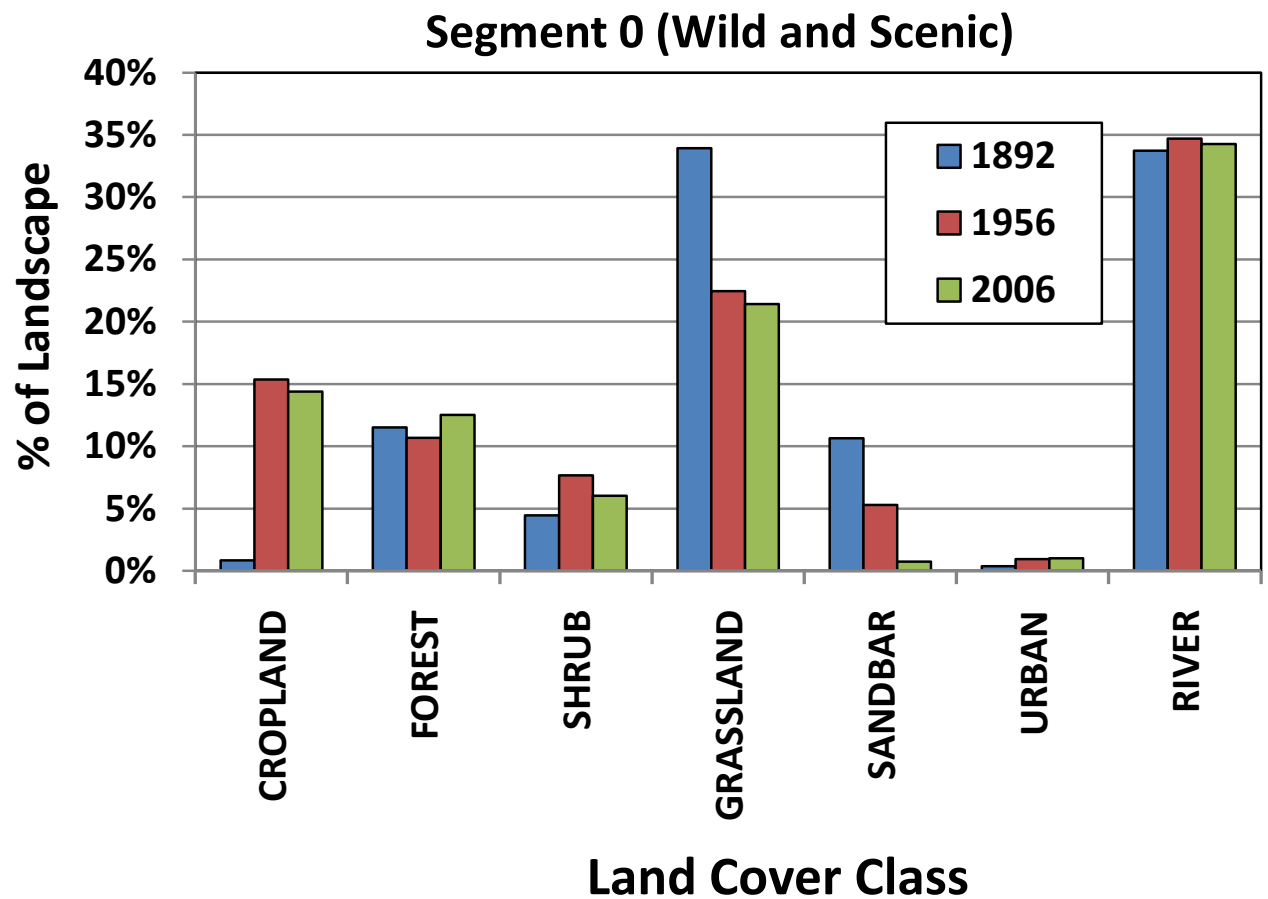

Figure 6h. Historic changes in relative coverage of major land cover classes on segment 0 (Wild and Scenic River reach, Fort Benton to upper reaches of Fort Peck Reservoir). 


\section{\% Change in Forest Area (1892-1950s)}

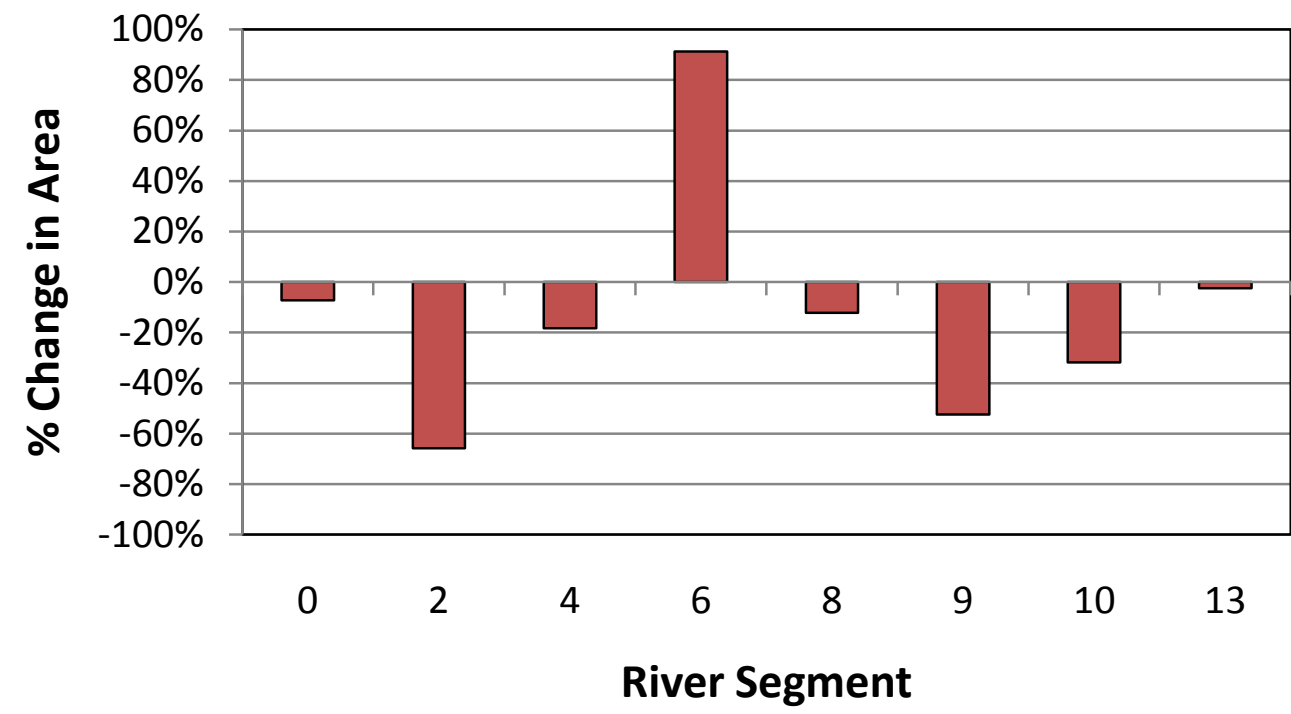

Figure 7. Percentage change in total forest area per study segment from 1892 through the mid1950s. Most forest declines were related to agricultural conversion.

\% Change in Forest Area (1950s-2006)

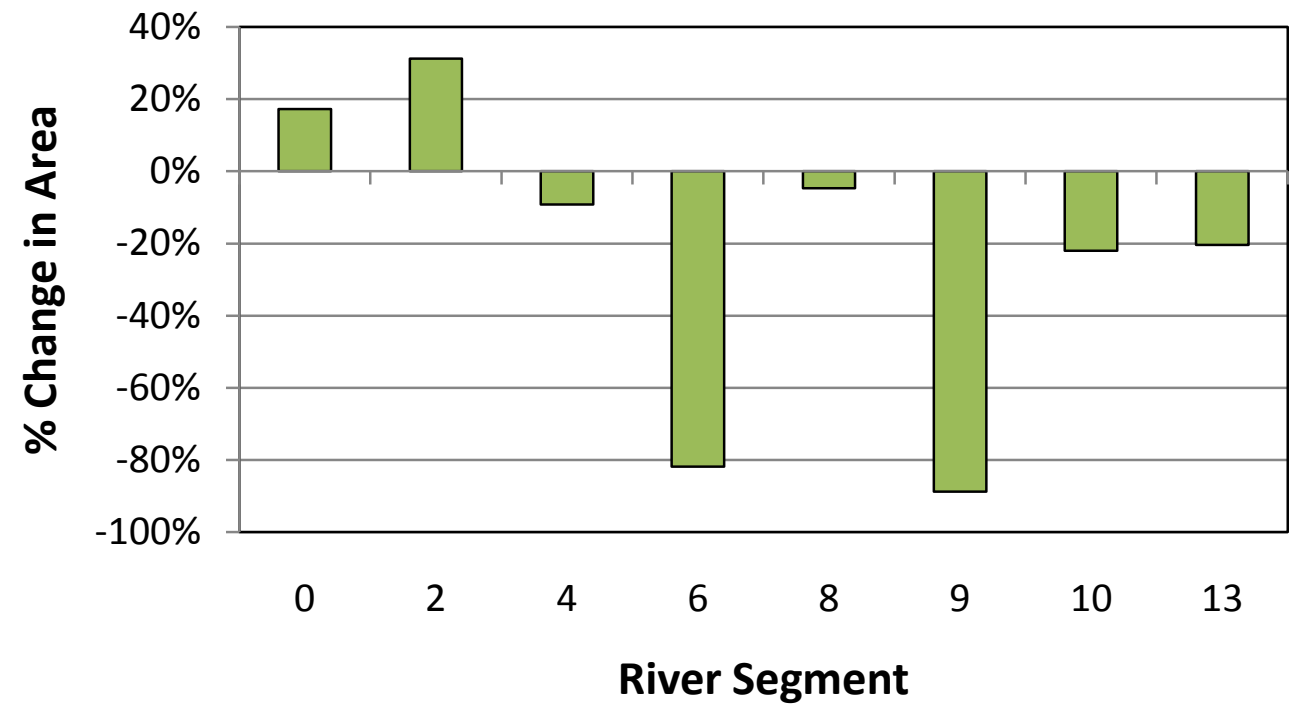

Figure 8. Percentage change in total forest area per study segment from mid-1950s through 2006. Largest declines $(>80 \%)$ are on the two segments with reservoirs - segments 6 (includes Lake Sharpe) and 9 (includes Lewis and Clark Reservoir), while forest area actually increased on the two most upstream segments (0 and 2 ) in Montana and western North Dakota. 
\% Change in Forest Area (1892-2006)

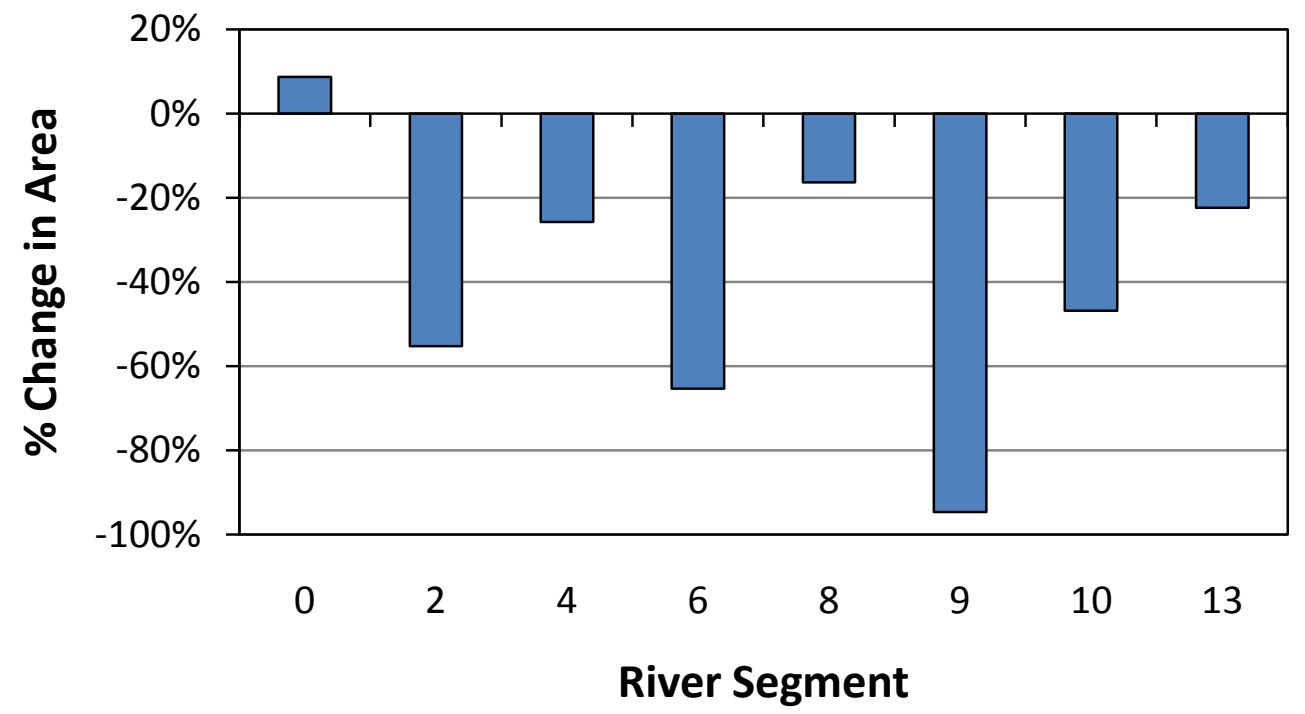

Figure 9. Percentage change in total forest area per study segment from 1892 through 2006 . Total forest area includes both cottonwood and non-cottonwood types. The only segment without a decline is the relatively free-flowing Wild and Scenic segment (segment 0), upstream of Fort Peck reservoir in Montana.

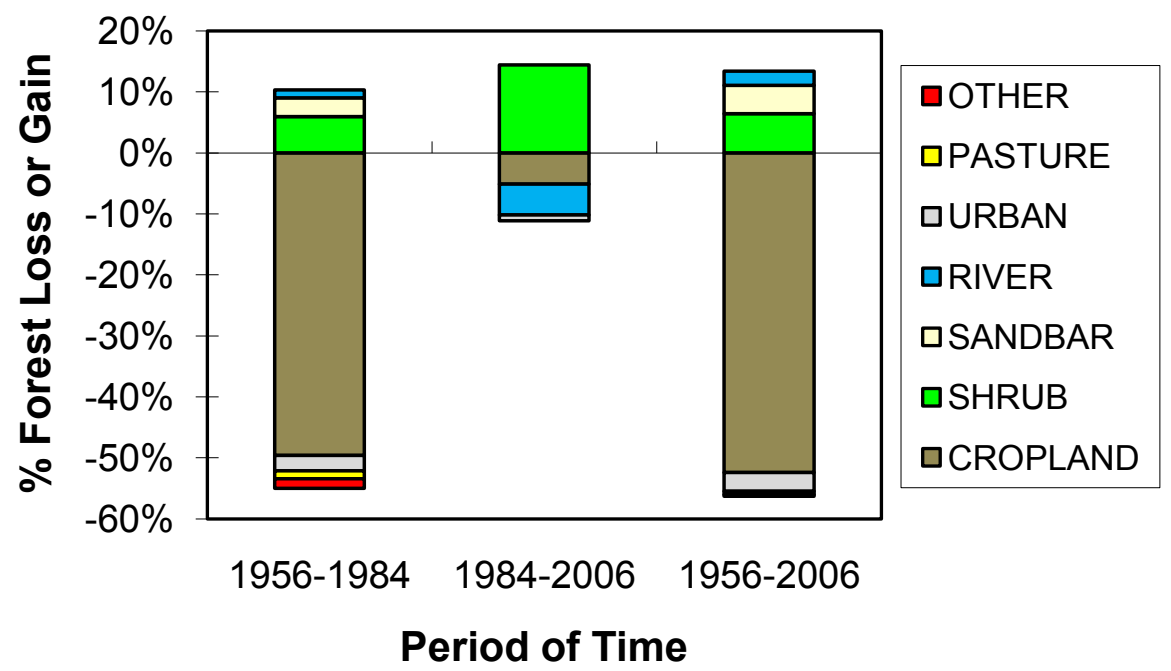

Figure 10. Net land cover conversions to or from forest in segment 10 from 1956 and 1984 to 2006. Dominant mode of forest loss was conversion to agricultural cropland, while dominant mode of forest gain was via maturation of shrubs or saplings to forest. 


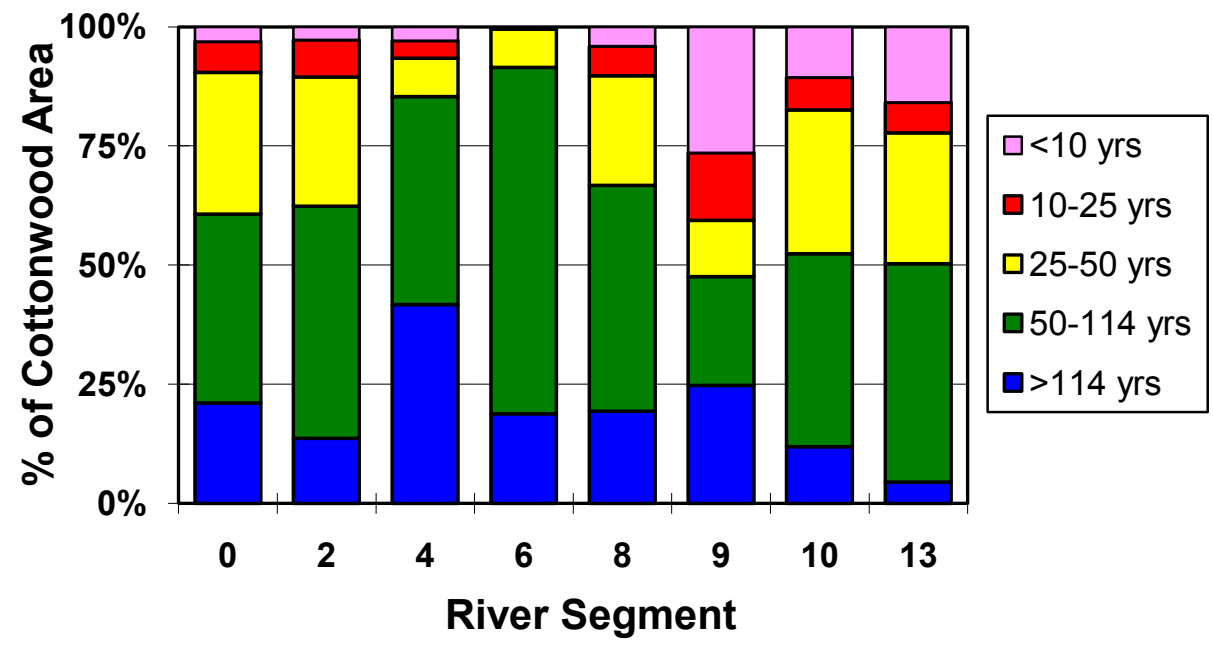

Figure 11. Relative area of different cottonwood age classes on each study segment. Lowest proportion of forest $<50$ years old occurs on segments 4 (below Garrison) and 6 (below Oahe), signifying little new recruitment of cottonwood forest since dam closure on/upstream of those segments.

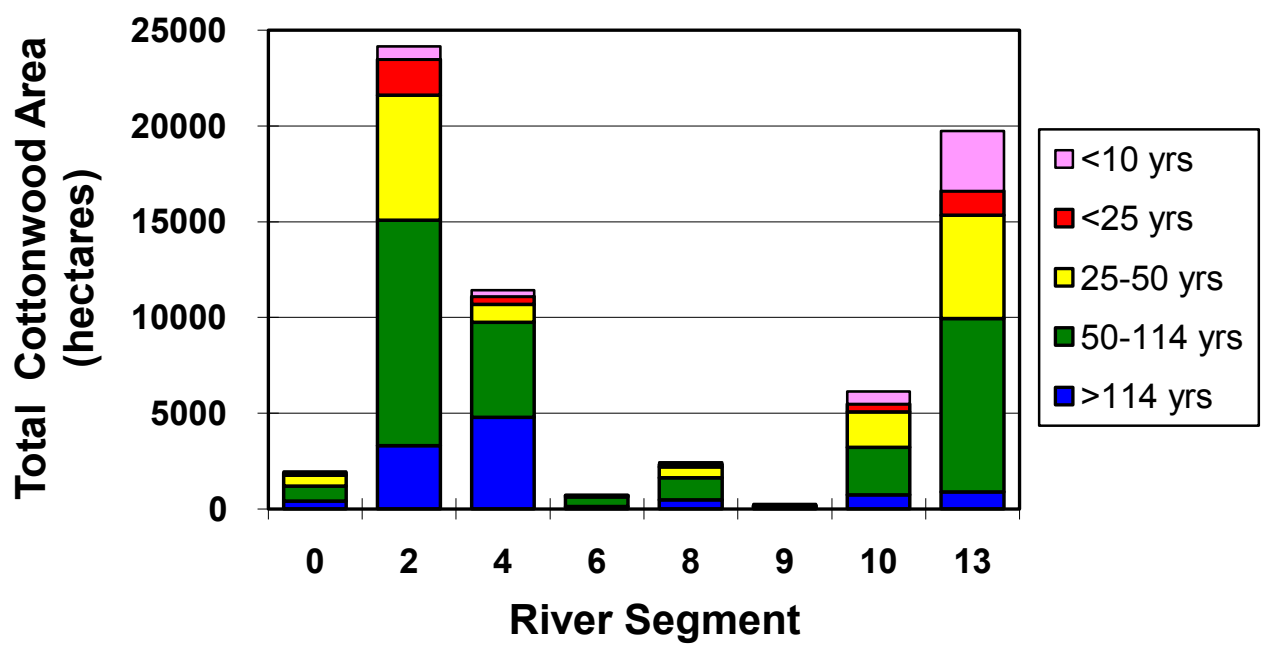

Figure 12. Total cottonwood area (hectares), by age class, on each study segment. 


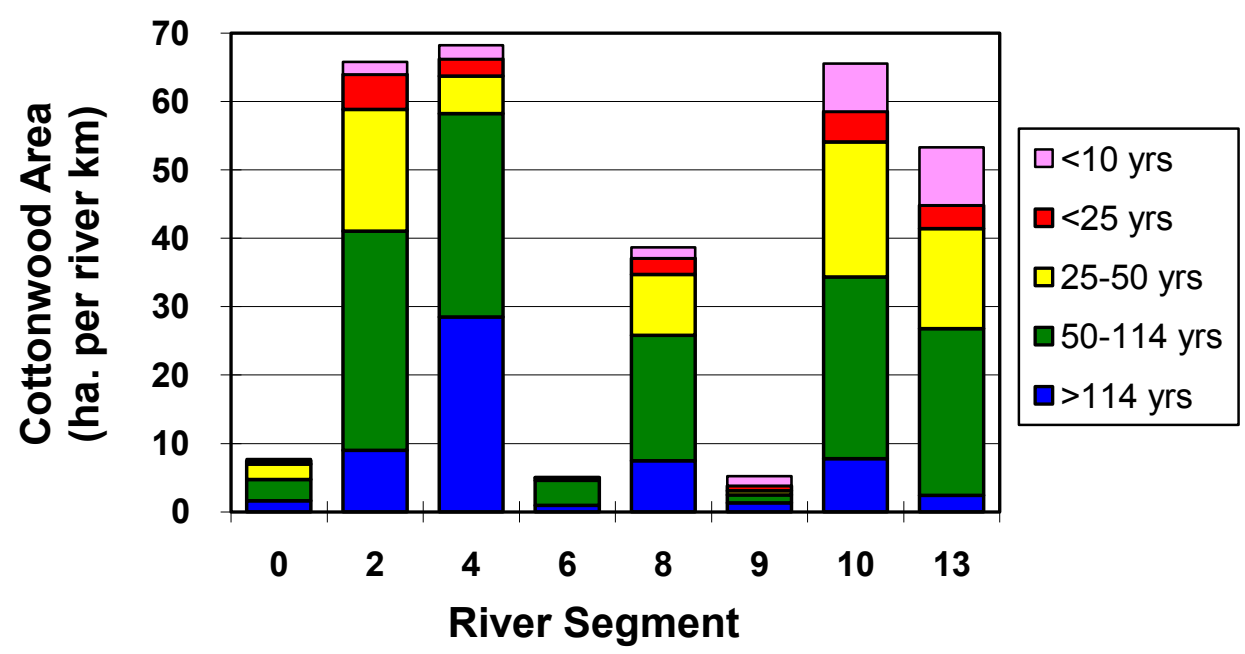

Figure 13. Mean cottonwood area (hectares) per river kilometer, by age class, on each study segment. Lowest areas per river kilometer were on two segments with reservoirs (segments 6 and 9) and the relatively free-flowing, but geologically-constrained, Wild and Scenic River segment (segment $0)$ in Montana.

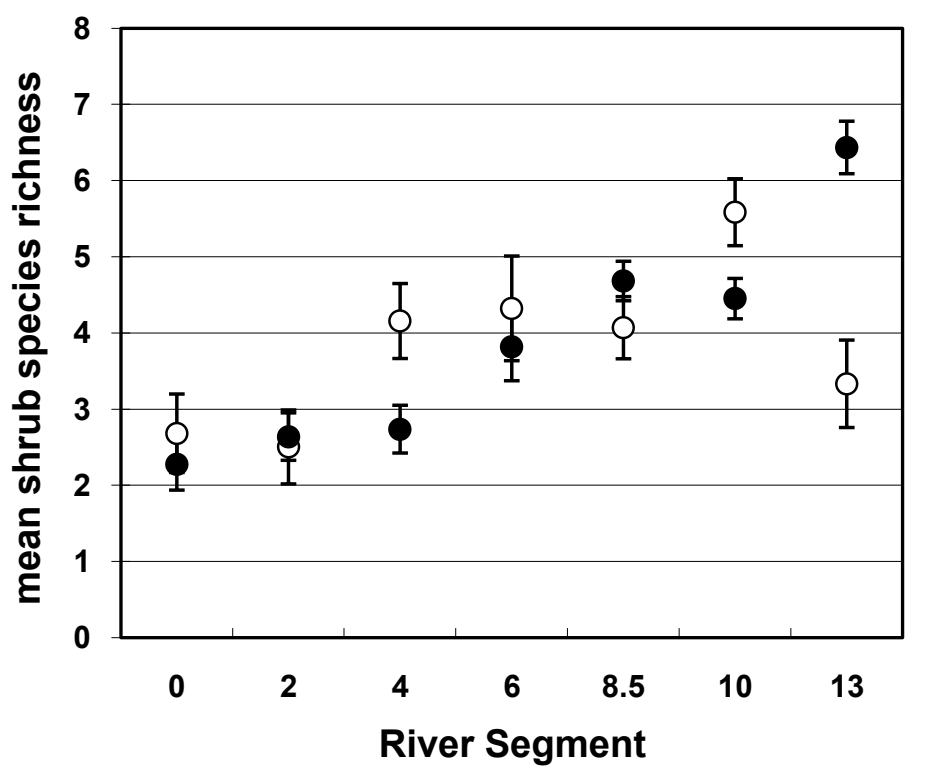

Oshrub richness - tree richness

Figure 14. Adjusted mean ( \pm standard error) overall shrub-layer and tree species richness for cottonwood stands (disturbed stands excluded) across Missouri River study segments. Average number of tree species (particularly for later successional species) declines progressively from most downstream (13) to farthest upstream (0) study segments. 


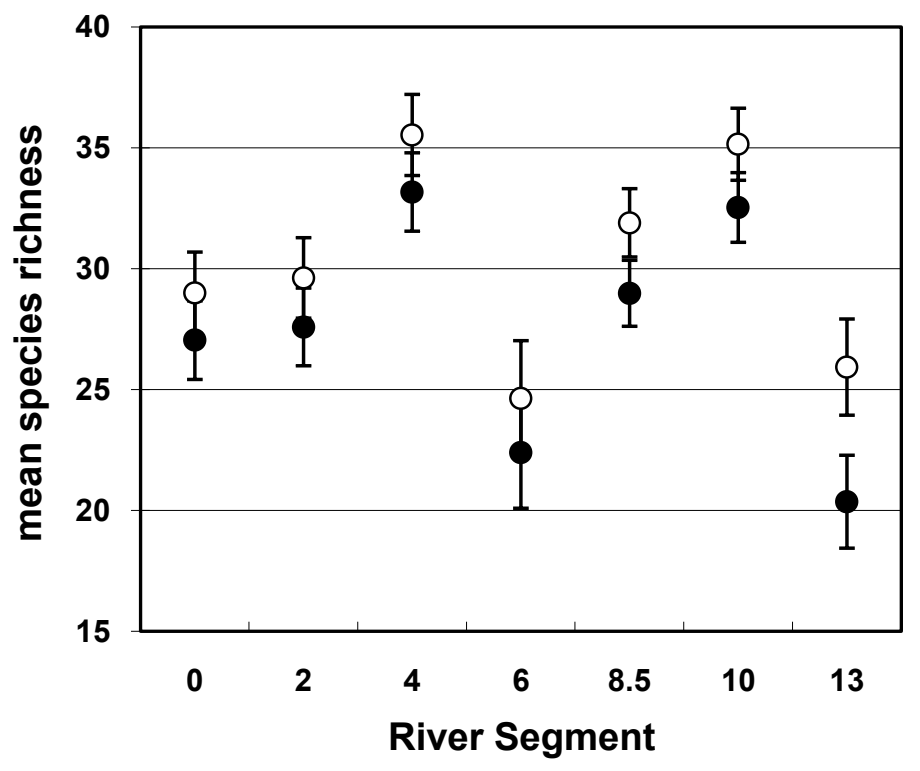

Ototal richness herb richness

Figure 15. Adjusted mean ( \pm standard error) overall stand and herb-layer plant species richness for cottonwood stands (disturbed stands excluded) across Missouri River study segments. Cottonwood stands with the highest mean number of all species and herbaceous species were in segments 4 (below Garrison) and 10 (below Gavins Point).

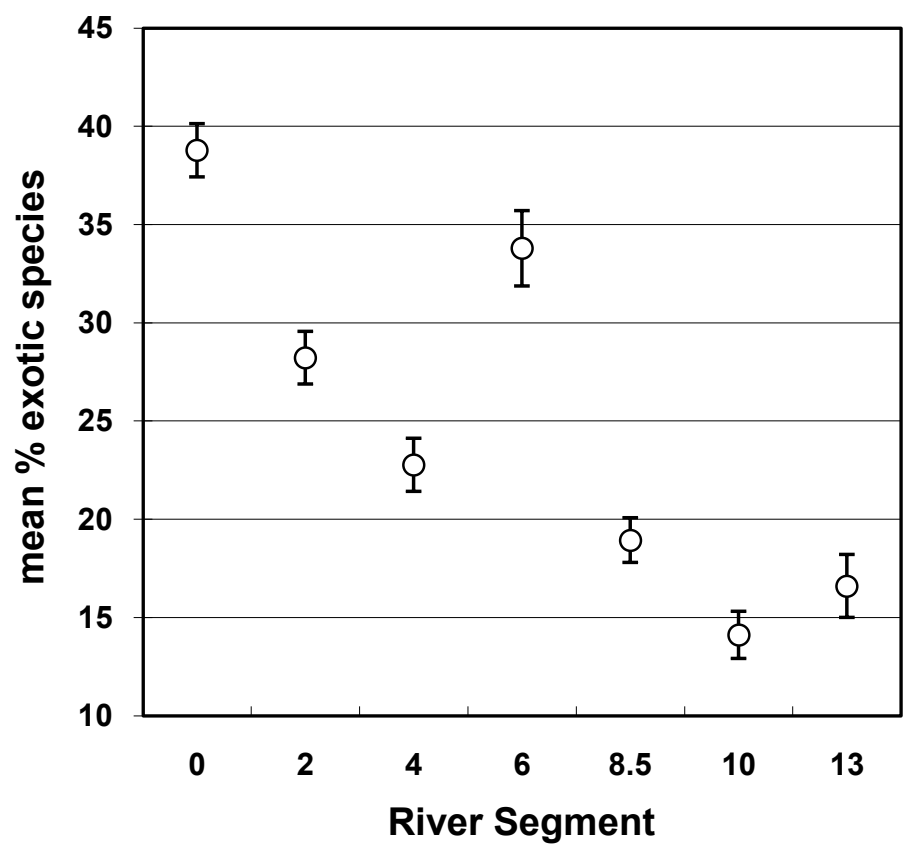

Figure 16. Adjusted mean \% ( \pm standard error) of plant species (all layers) that are non-native for cottonwood stands (disturbed stands excluded) across Missouri River study segments. As shown above, proportion of exotic species generally increased from downstream to upstream, with the exception of the heavily modified segment 6 (Oahe Dam to Big Bend Dam), which had higher proportions of exotic species than the next segments upstream and downstream. 


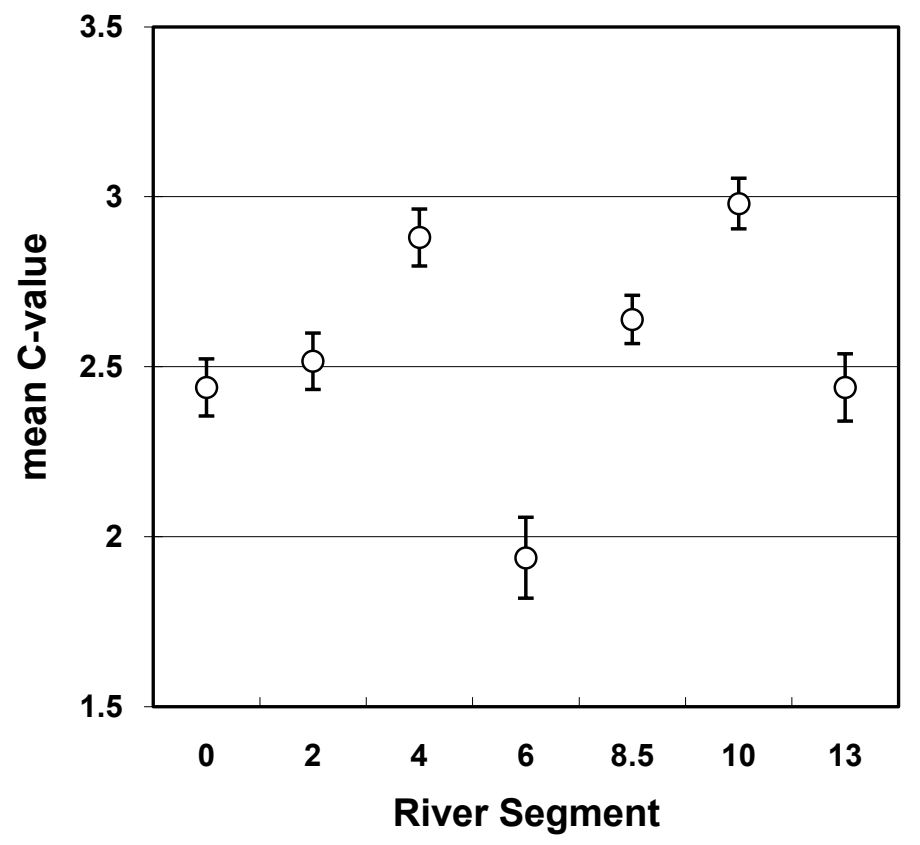

Figure 17. Overall stand (all layers) adjusted mean ( \pm standard error) Coefficient of Conservatism values for cottonwood stands (disturbed stands excluded) across Missouri River study segments. Highest average C-values were in segments 4 (below Garrison) and 10 (below Gavins Point), signifying highest floristic quality on those sites, with the lowest values (signifying low floristic quality) in segment 6 (Oahe Dam to Big Bend Dam).

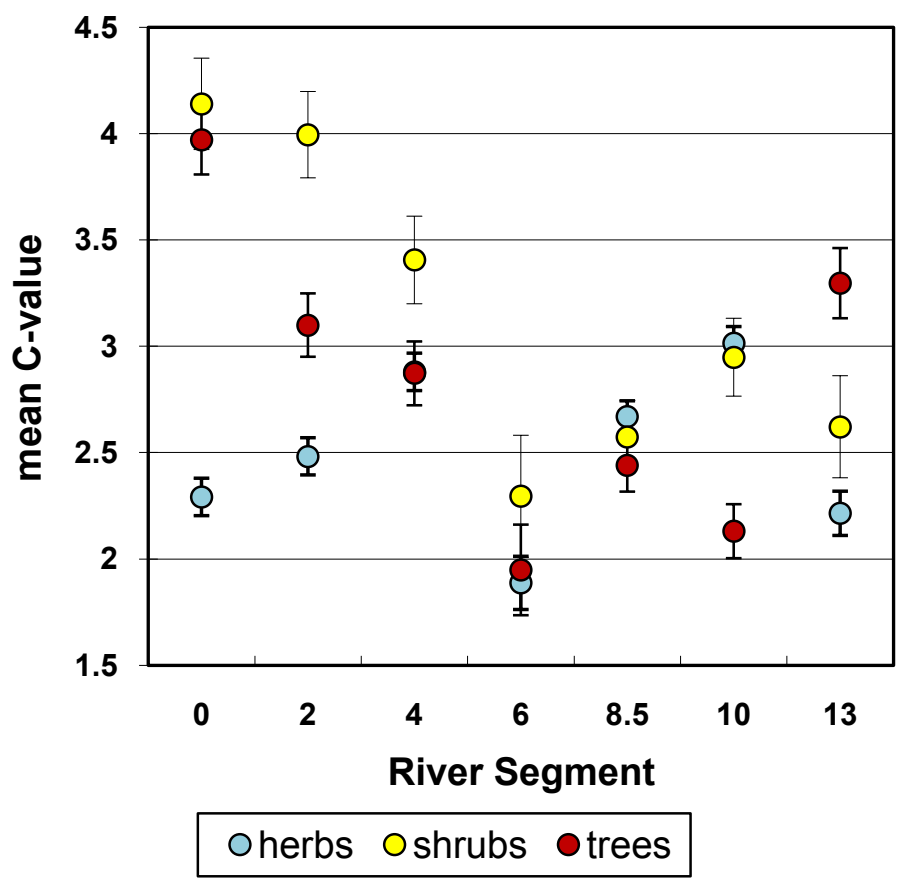

Figure 18. Adjusted mean ( \pm standard error) Coefficient of Conservatism values for the herb-layer, shrub-layer, and overstory (trees) in cottonwood stands (disturbed stands excluded) across Missouri River study segments. 


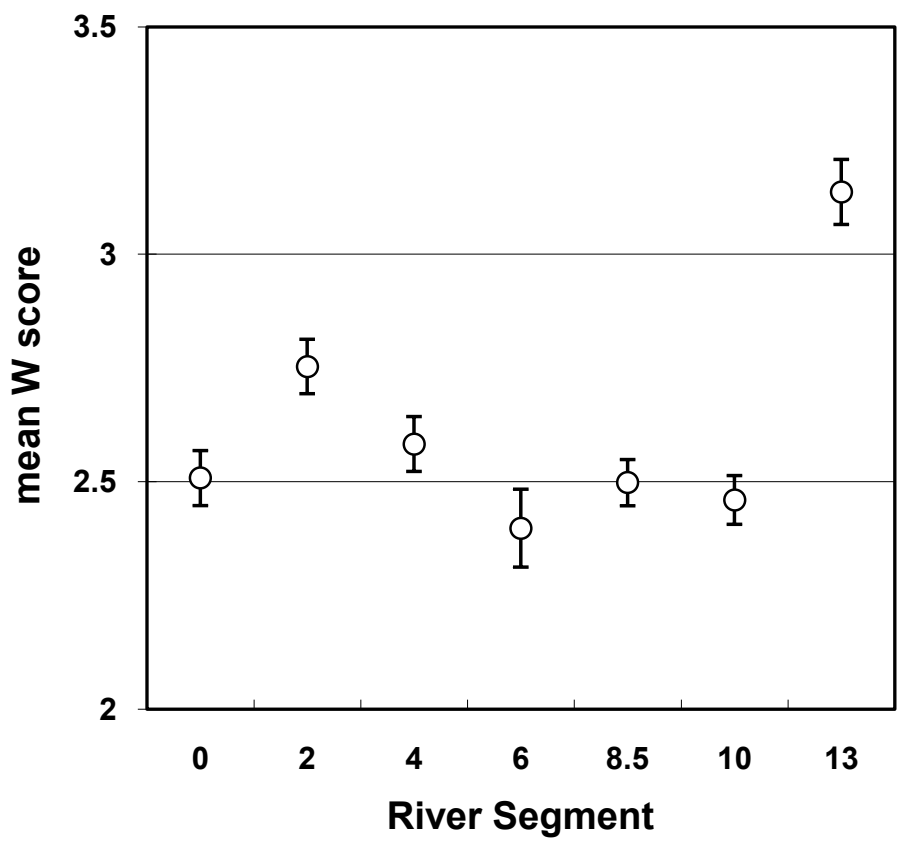

Figure 19. Adjusted mean ( \pm standard error) Wetland score $(1=$ UPL, $2=$ FACU, $3=$ FAC, $4=$ FACW, 5 = OBL) of plant species within cottonwood stands (disturbed stands excluded) across study segments. Higher values in segment 13 (channelized segment between Plattsmouth, NE and Kansas City, MO) suggest a higher prevalence of wetland species in the flora, which may reflect more frequent flooding (including sampling season in 2008) on that segment than the others.

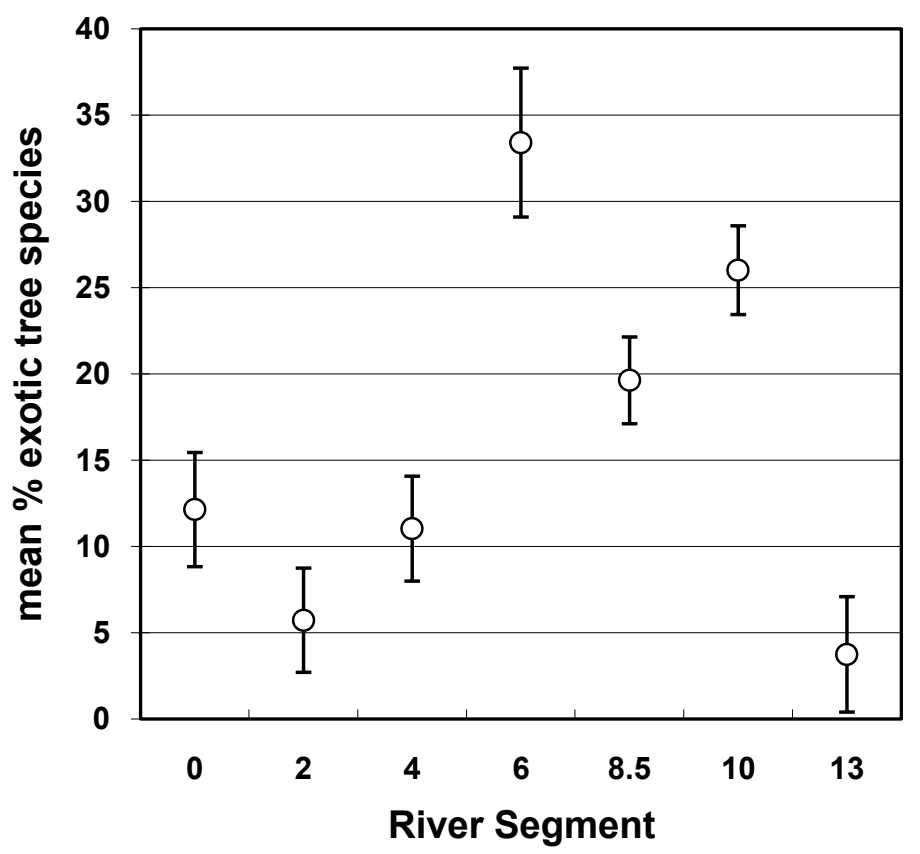

Figure 20. Adjusted mean \% ( \pm standard error) of tree species that are non-native for cottonwood stands (disturbed stands excluded) across Missouri River study segments. Highest percentages of exotic tree species occur on the South Dakota segments $(6,8 / 9$, and 10$)$. 
Importance Value of Tree Species in Cottonwood Stands, Segment 13

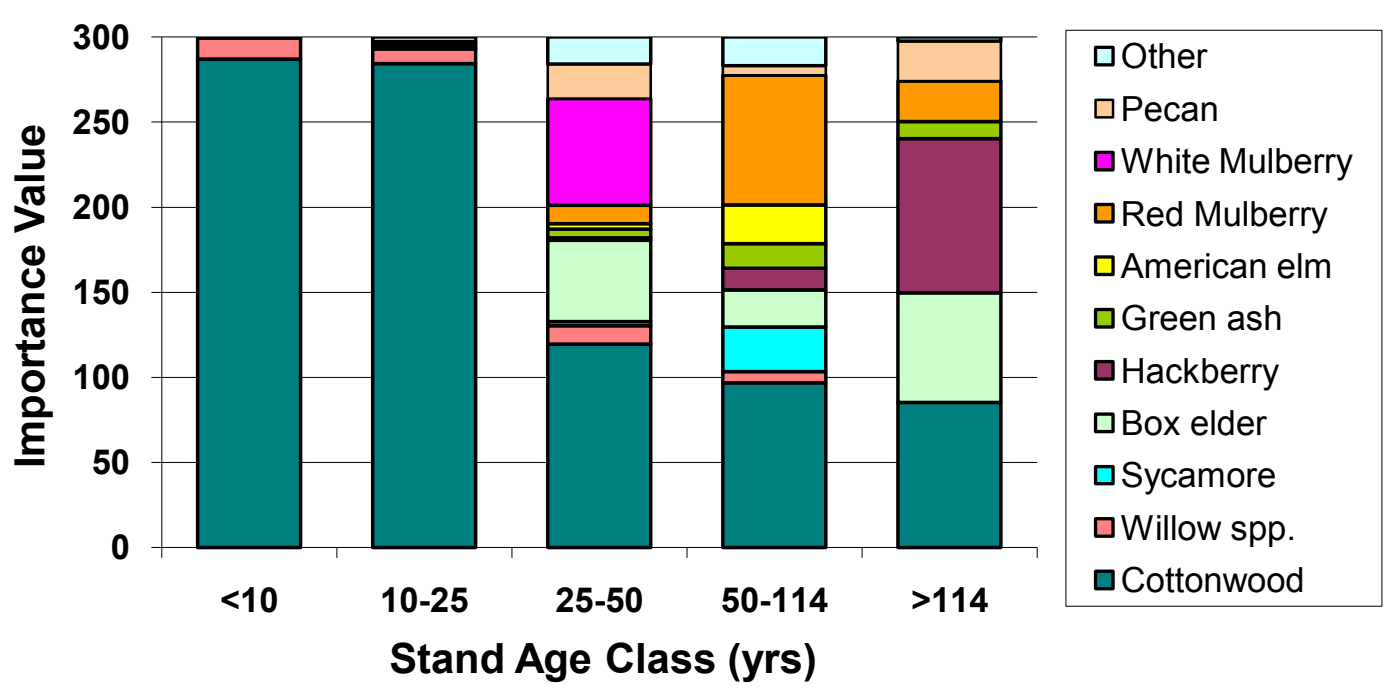

Figure 21a. Relative importance value (sum of relative frequency, density, and basal area) of different tree species by cottonwood forest age class in segment 13. Data for $>114$ years old age class were from a single stand.

Importance Value of Tree Species in Disturbed and Non-cottonwood Stands, Segment 13

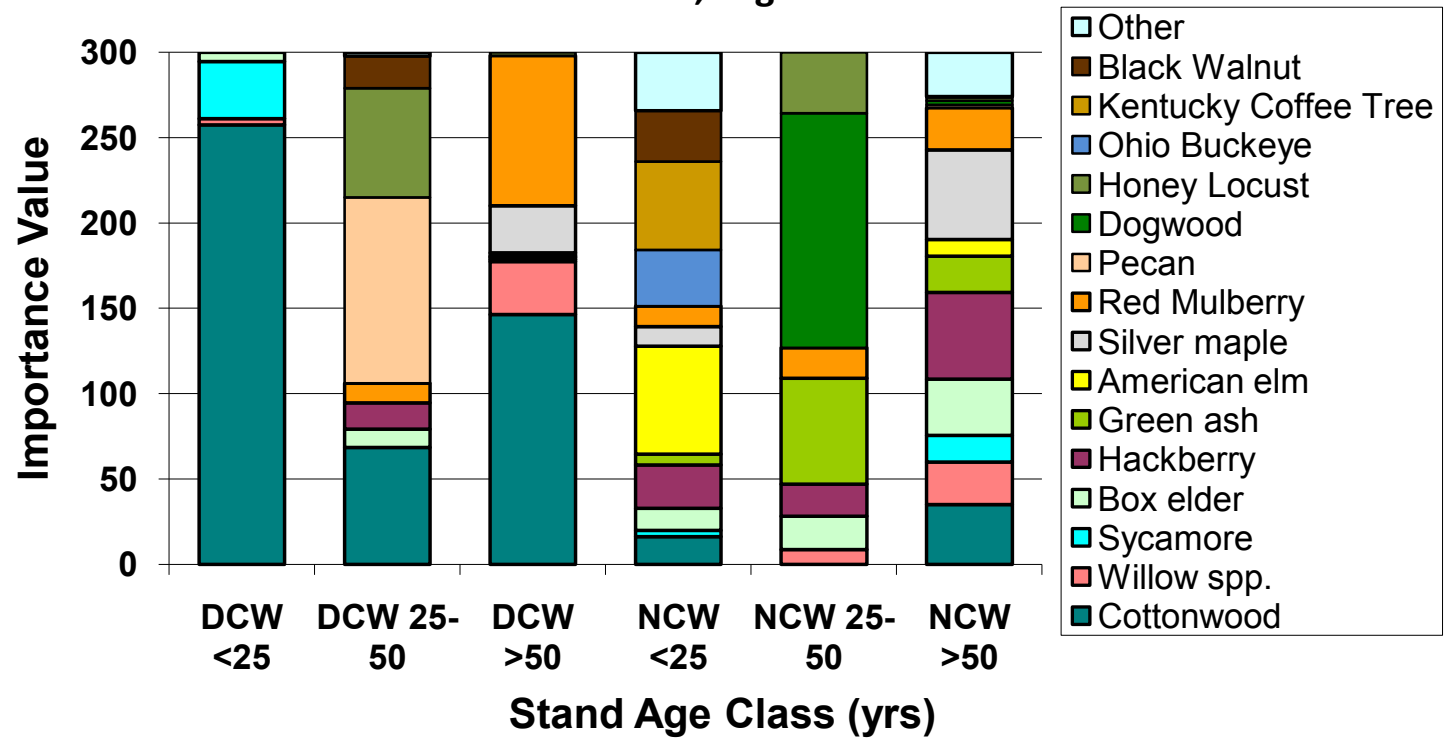

Figure 21b. Relative importance value (sum of relative frequency, density, and basal area) of different tree species within disturbed cottonwood and non-cottonwood forests in segment 13 . DCW refers to disturbed cottonwood stands and NCW refers to non-cottonwood stands. Data for $\mathrm{DCW}<25$, DCW 25-50, NCW<25, and NCW 25-50 were from single stands of each type. 
Cover of Shrub Species in Cottonwood Stands, Segment 13

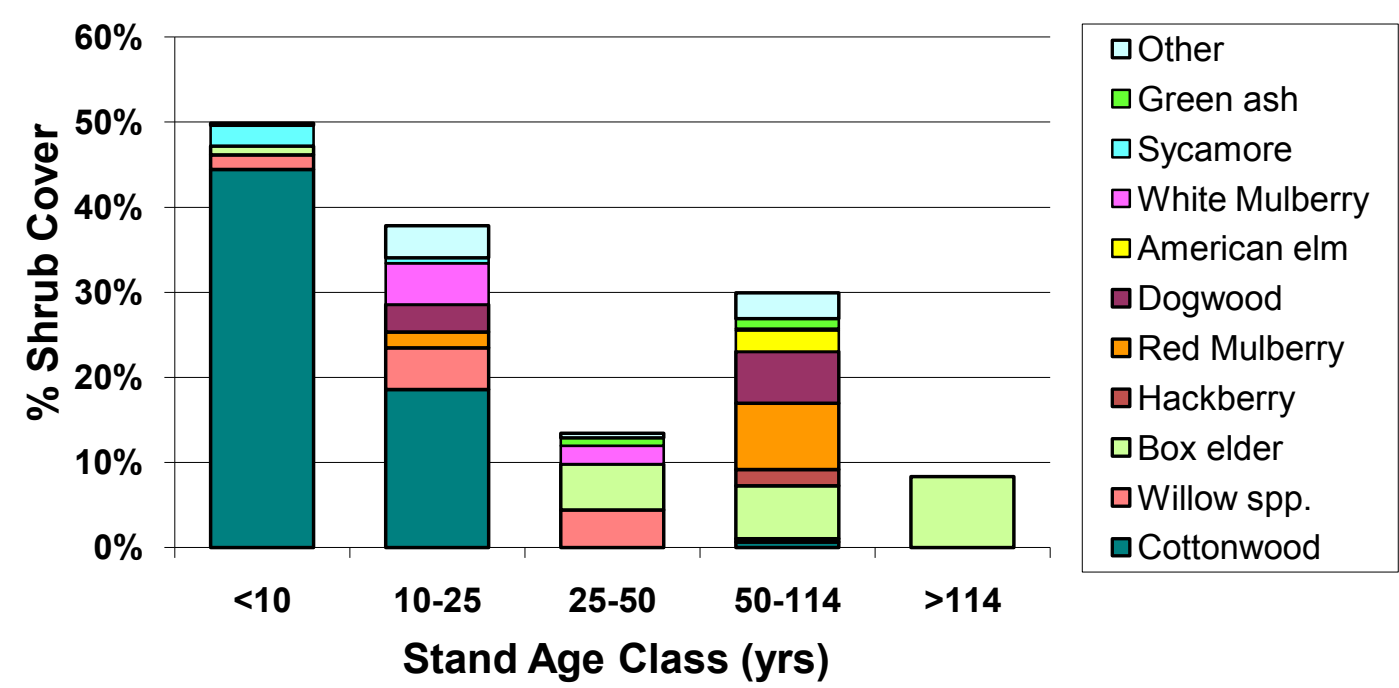

Figure 22a. Mean percent shrub cover by different species and overall mean shrub cover by cottonwood forest age class in segment 13. Estimates of total shrub cover may be inflated because of overlapping cover of different species along the transect segments. Data for $>114$ years old age class were from a single stand.

Cover of Shrub Species in Disturbed and Non-cottonwood Stands, Segment 13

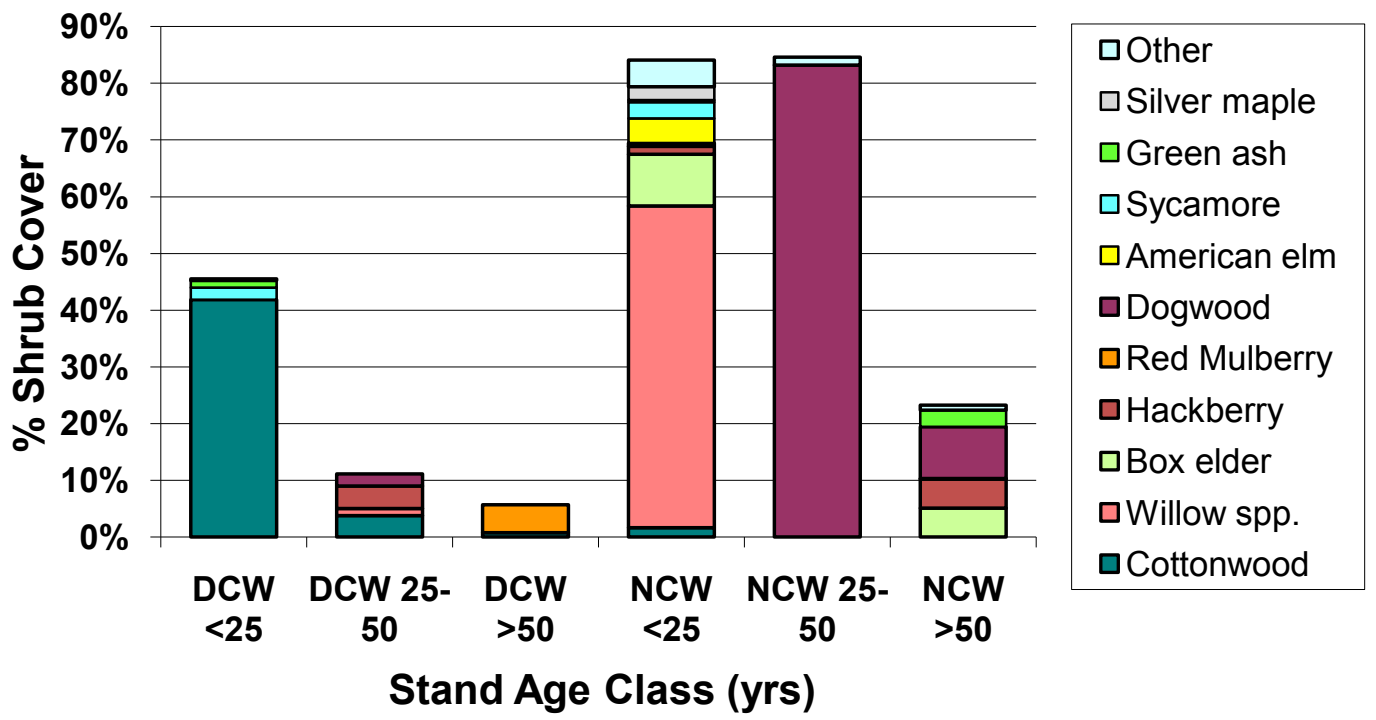

Figure 22b. Mean percent shrub cover by different species and overall mean shrub cover within non-cottonwood and disturbed cottonwood forests in segment 13. Estimates of total shrub cover may be inflated because of overlapping cover of different species along the transect segments. DCW refers to disturbed cottonwood stands and NCW refers to non-cottonwood stands. Data for $\mathrm{DCW}<25$, DCW 25-50, and NCW 25-50 were from single stands of each type. 
Importance Value of Tree Species in Cottonwood Stands, Segment 10

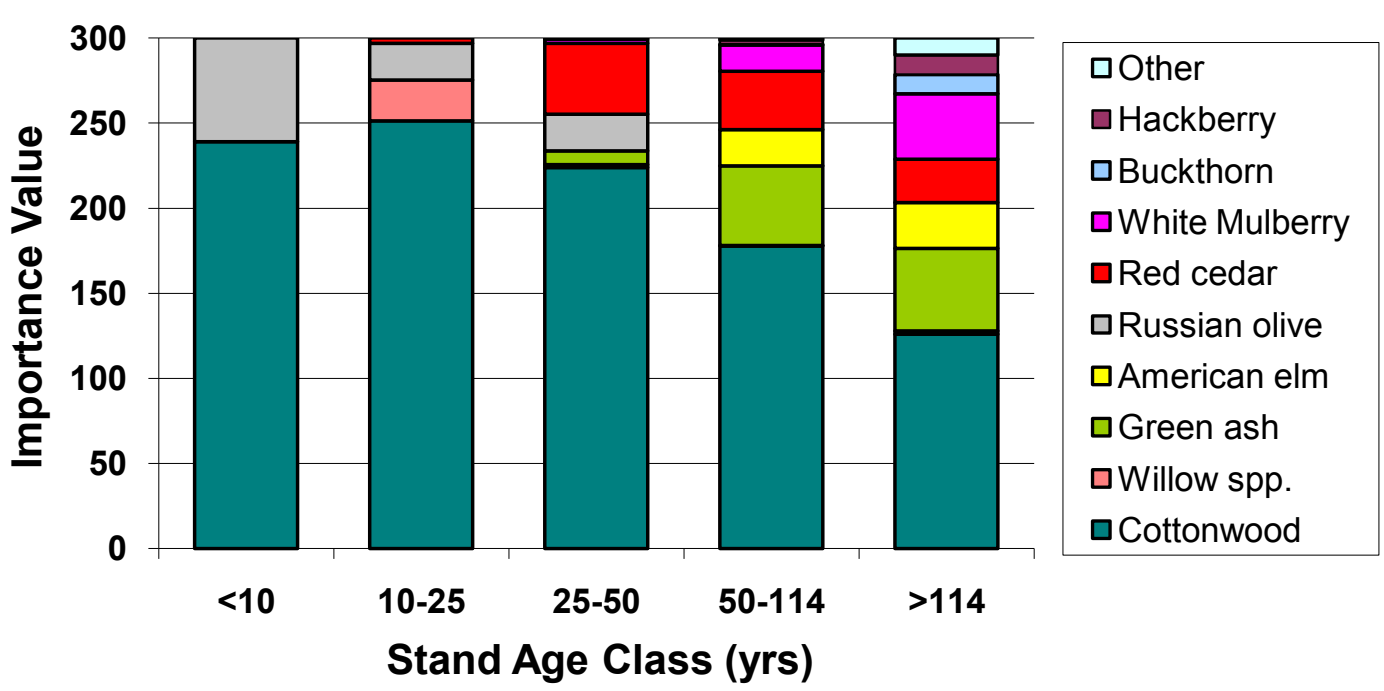

Figure 23a. Relative importance value (sum of relative frequency, density, and basal area) of different tree species by cottonwood forest age class in segment 10.

Importance Value of Tree Species in Disturbed and Non-cottonwood Stands, Segment 10

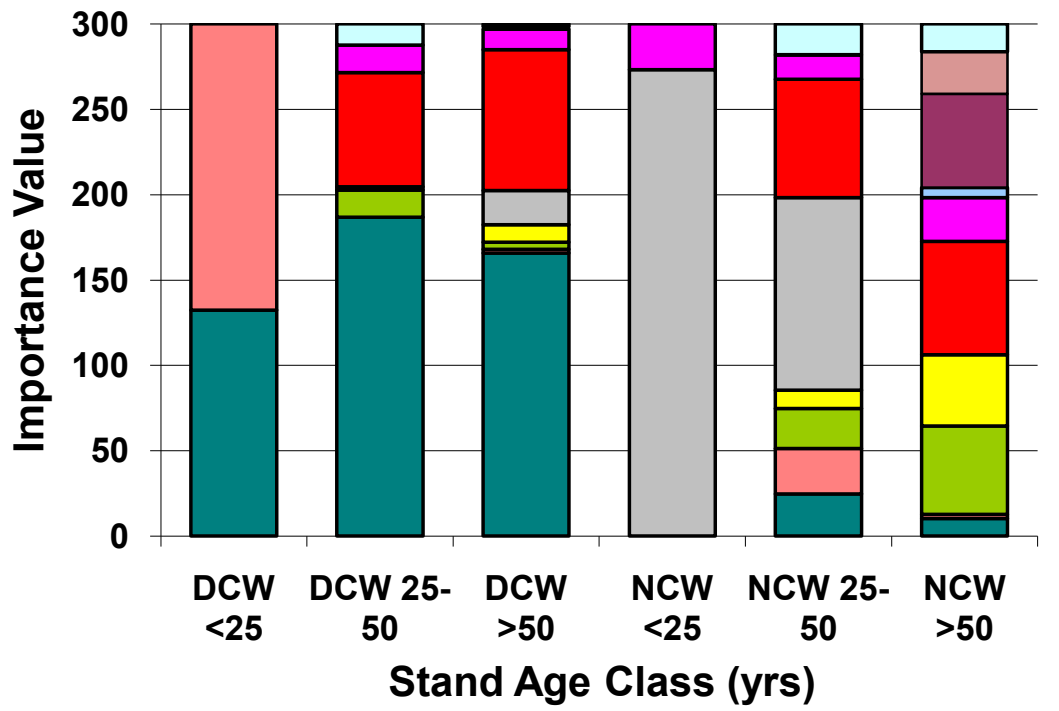

口Other

口Oak

口Hackberry

口Buckthorn

$\square$ White Mulberry

a Red cedar

$\square$ Russian olive

$\square$ American elm

$\square$ Green ash

$\square$ Willow spp.

$\square$ Cottonwood

Figure 23b. Relative importance value (sum of relative frequency, density, and basal area) of different tree species within disturbed cottonwood and non-cottonwood forests in segment 10. DCW refers to disturbed cottonwood stands and NCW refers to non-cottonwood stands. Data for DCW 2550 and NCW $<25$ were from single stands of each type. 


\section{Cover of Shrub Species in Cottonwood Stands, Segment 10}

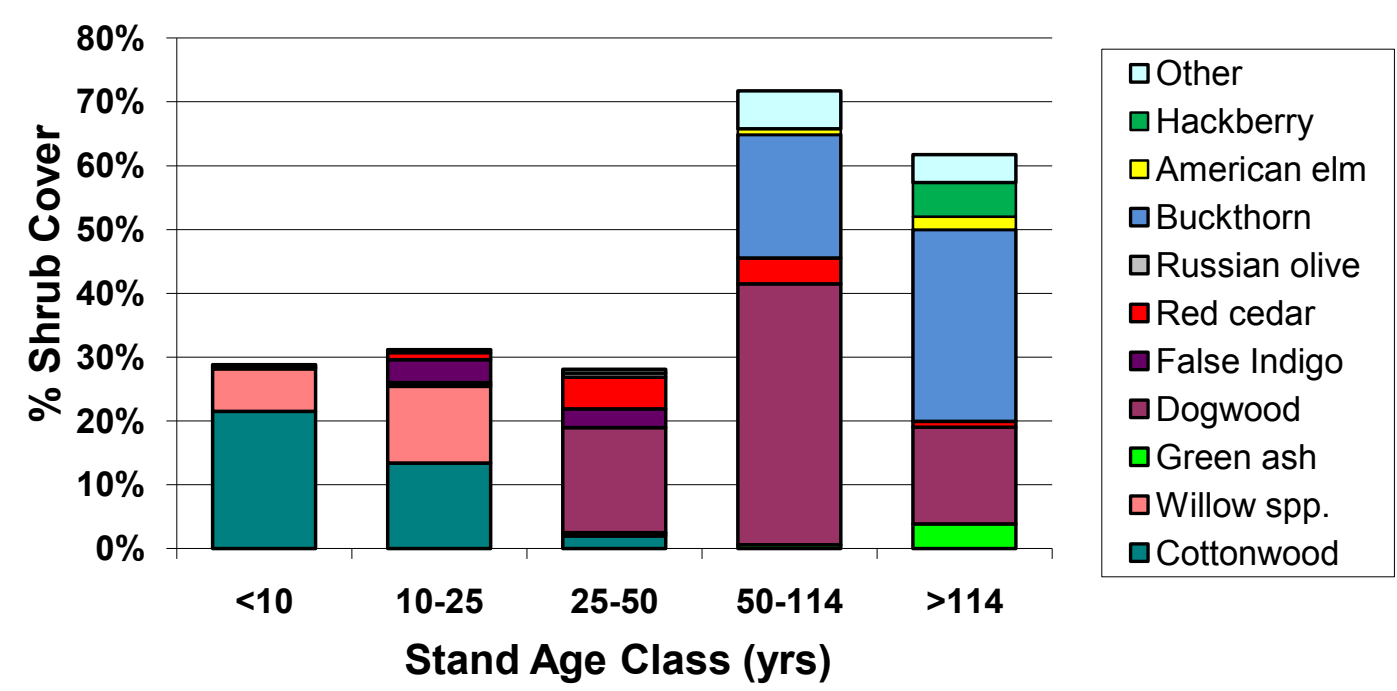

Figure 24a. Mean percent shrub cover by different species and overall mean shrub cover by cottonwood forest age class in segment 10. Estimates of total shrub cover may be inflated because of overlapping cover of different species along the transect segments.

Cover of Shrub Species in Disturbed and Non-cottonwood Stands, Segment 10

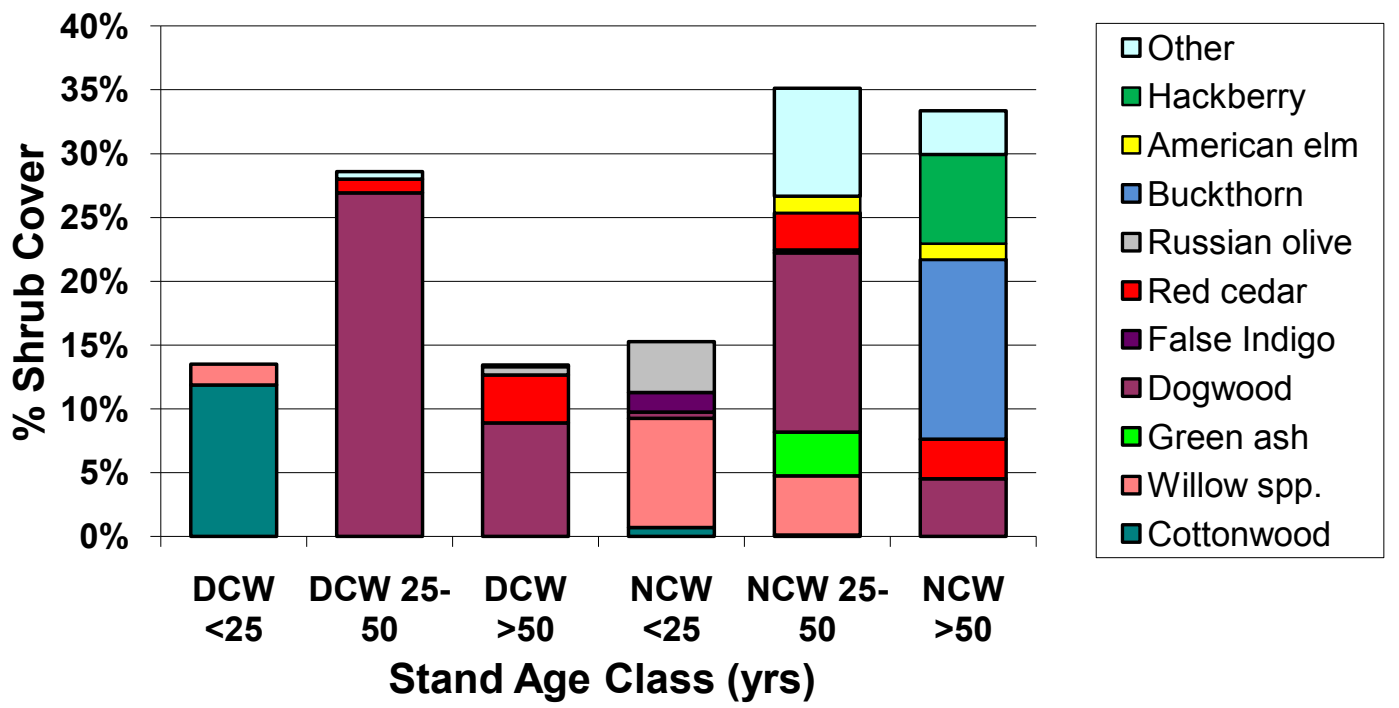

Figure 24b. Mean percent shrub cover by different species and overall mean shrub cover within non-cottonwood and disturbed cottonwood forests in segment 10. Estimates of total shrub cover may be inflated because of overlapping cover of different species along the transect segments. DCW refers to disturbed cottonwood stands and NCW refers to non-cottonwood stands. Data for DCW 25-50 were from a single stand. 
Importance Value of Tree Species in Cottonwood Stands, Segments 8 and 9

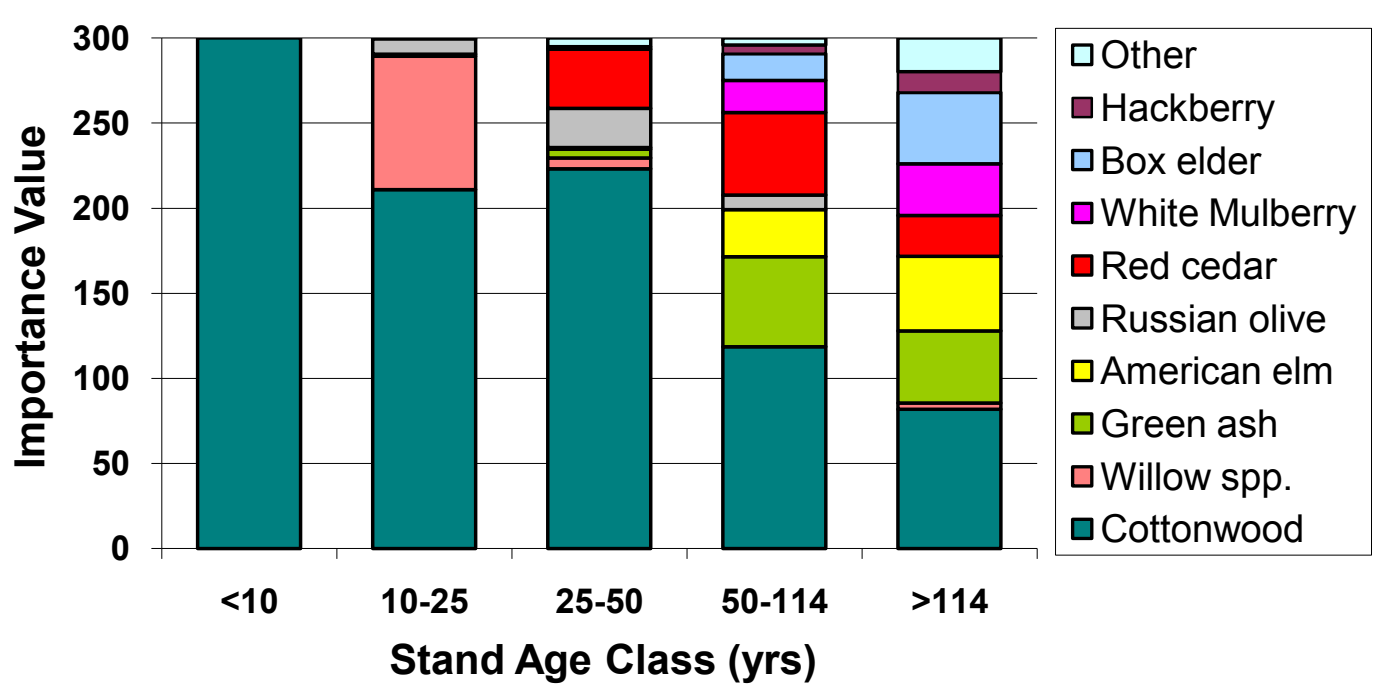

Figure 25a. Relative importance value (sum of relative frequency, density, and basal area) of different tree species by cottonwood forest age class in segments 8 and 9 . Data for $<10$ years old age class were from a single stand.

Importance Value of Tree Species in Disturbed and Noncottonwood Stands, Segments 8 and 9

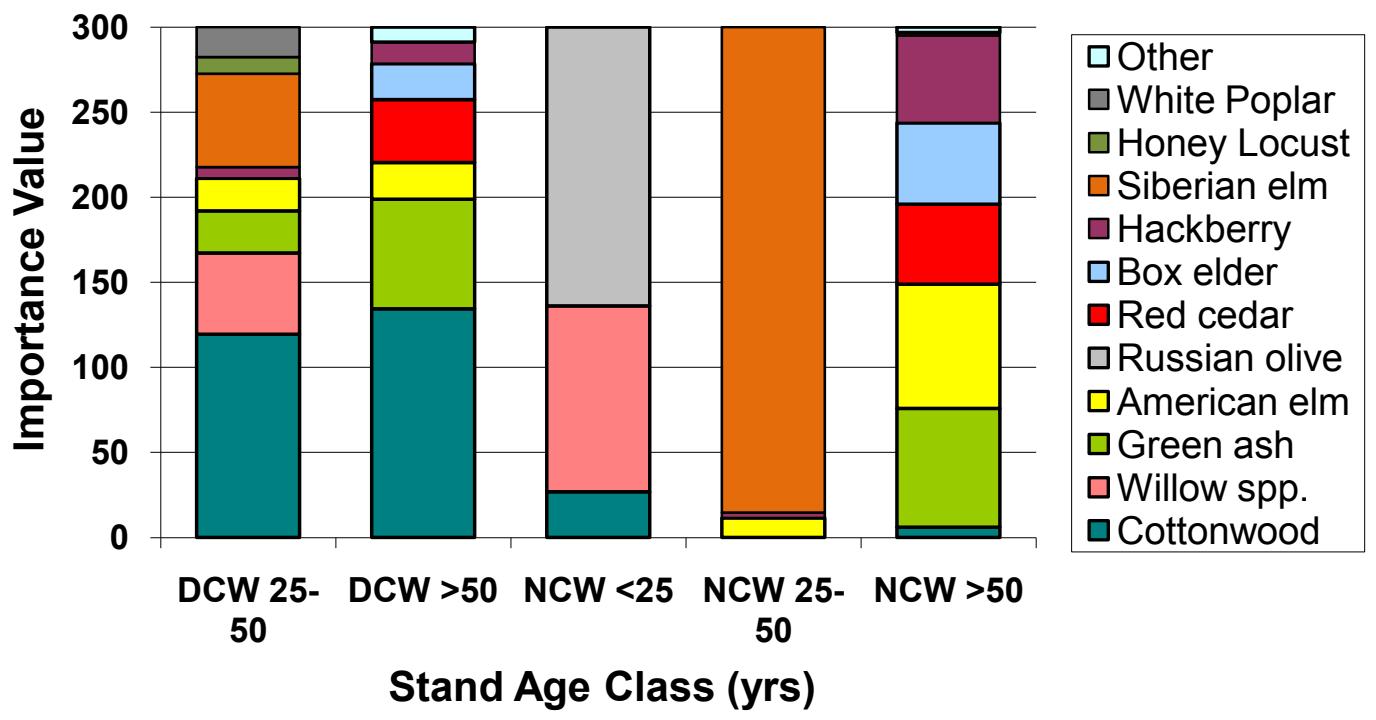

Figure 25b. Relative importance value (sum of relative frequency, density, and basal area) of different tree species within disturbed cottonwood and non-cottonwood forests in segments 8 and 9 . DCW refers to disturbed cottonwood stands and NCW refers to non-cottonwood stands. Data for DCW 25-50 and NCW 25-50 were from single stands of each type. 
Cover of Shrub Species in Cottonwood Stands, Segments 8 and 9

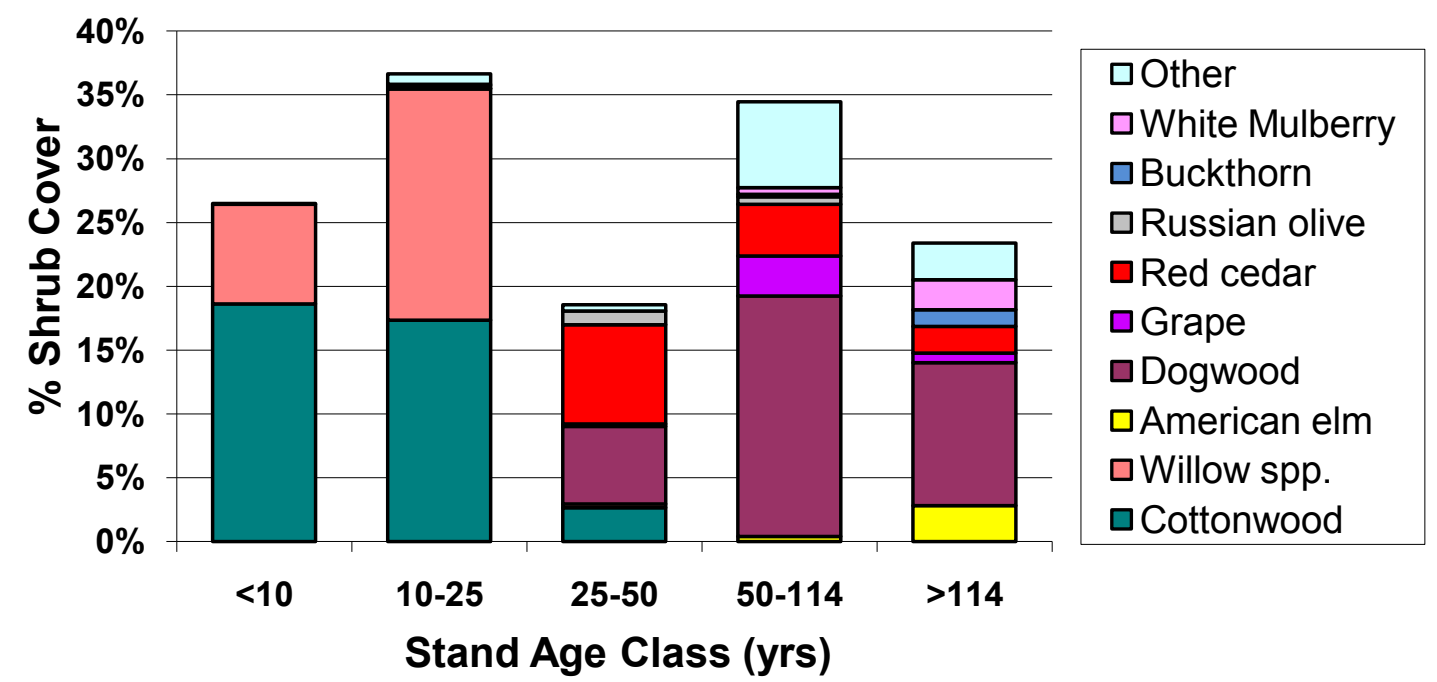

Figure 26a. Mean percent shrub cover by different species and overall mean shrub cover by cottonwood forest age class in segments 8 and 9. Estimates of total shrub cover may be inflated because of overlapping cover of different species along the transect segments.

Cover of Shrub Species in Dlsturbed and Non-cottonwood Stands, Segments 8 and 9

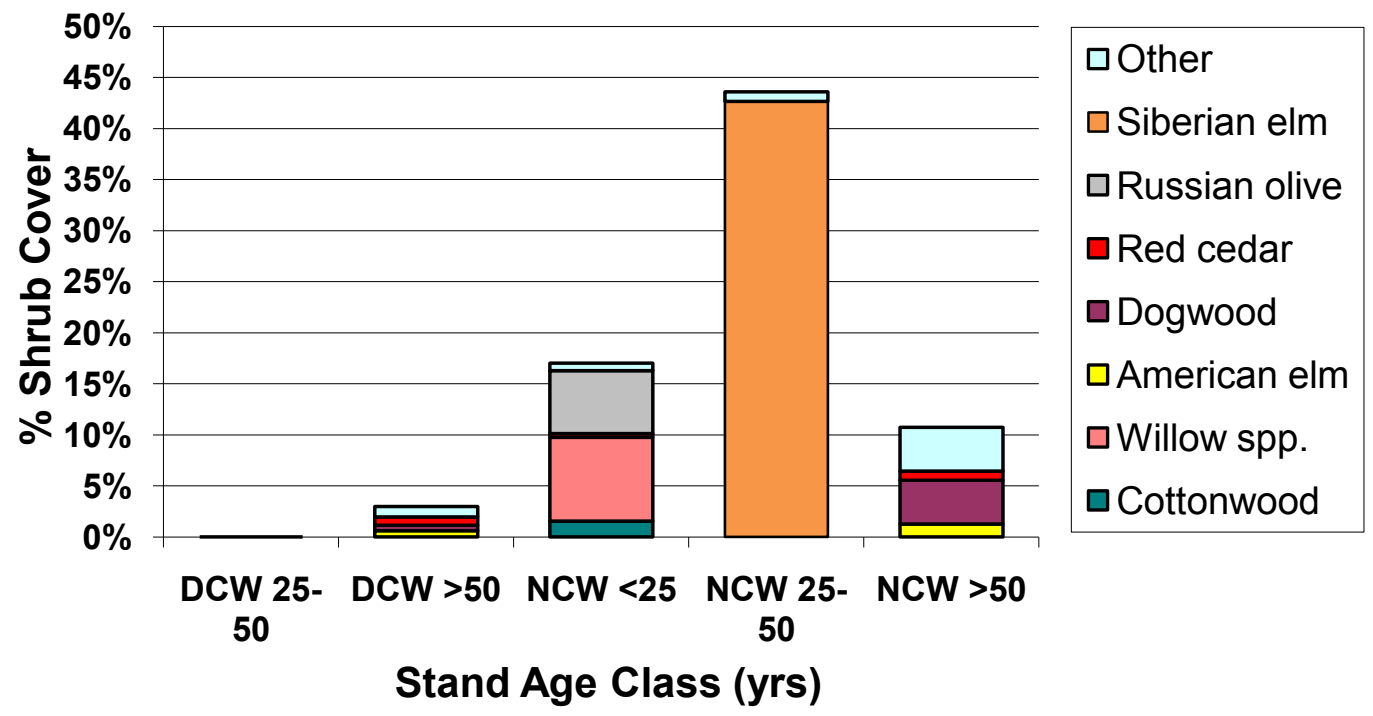

Figure 26b. Mean percent shrub cover by different species and overall mean shrub cover within non-cottonwood and disturbed cottonwood forests in segment 8 and 9. Estimates of total shrub cover may be inflated because of overlapping cover of different species along the transect segments. DCW refers to disturbed cottonwood stands and NCW refers to non-cottonwood stands. Data for DCW 25-50 and NCW 25-50 were from single stands of each type. 
Importance Value of Tree Species in Cottonwood Stands, Segment 6

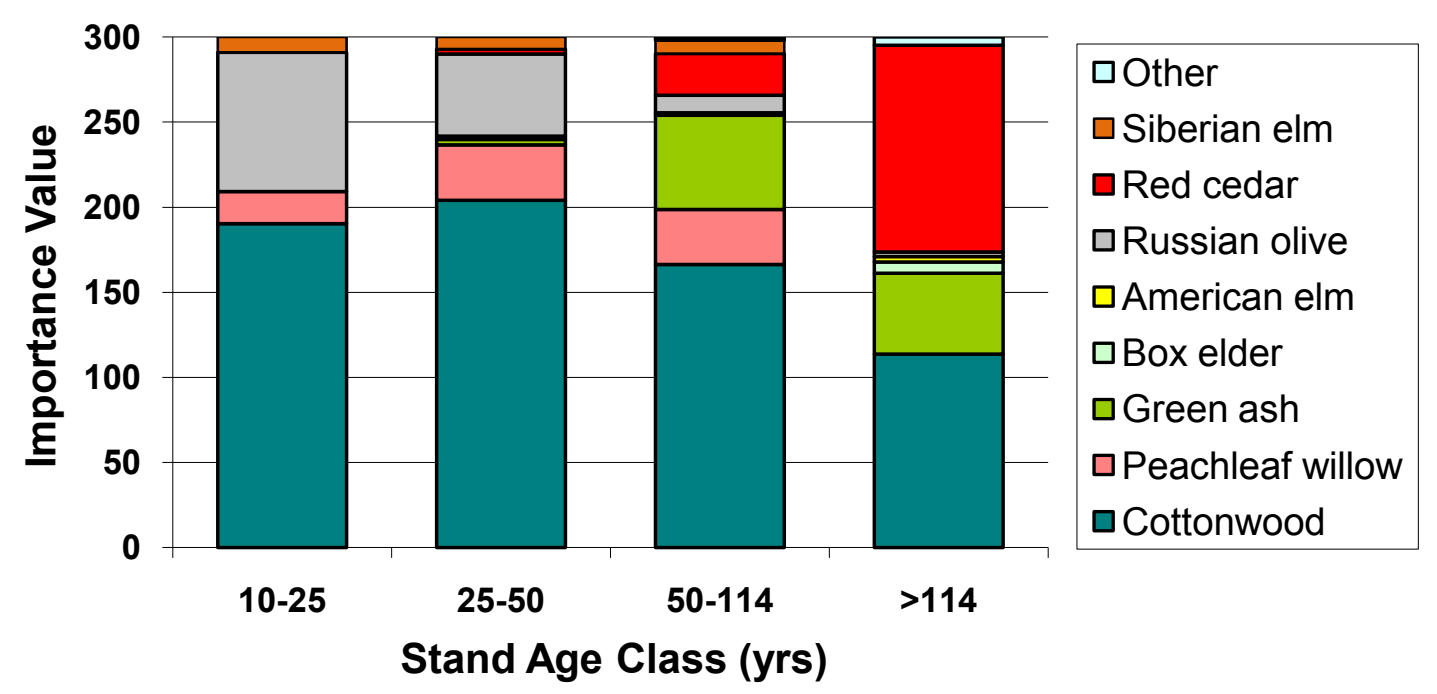

Figure 27a. Relative importance value (sum of relative frequency, density, and basal area) of different tree species by cottonwood forest age class in segment 6 . No cottonwood stands $<10$ years old were located that were of sufficient size for sampling.

Importance Value of Tree Species in Disturbed and Non-cottonwood Stands, Segment 6

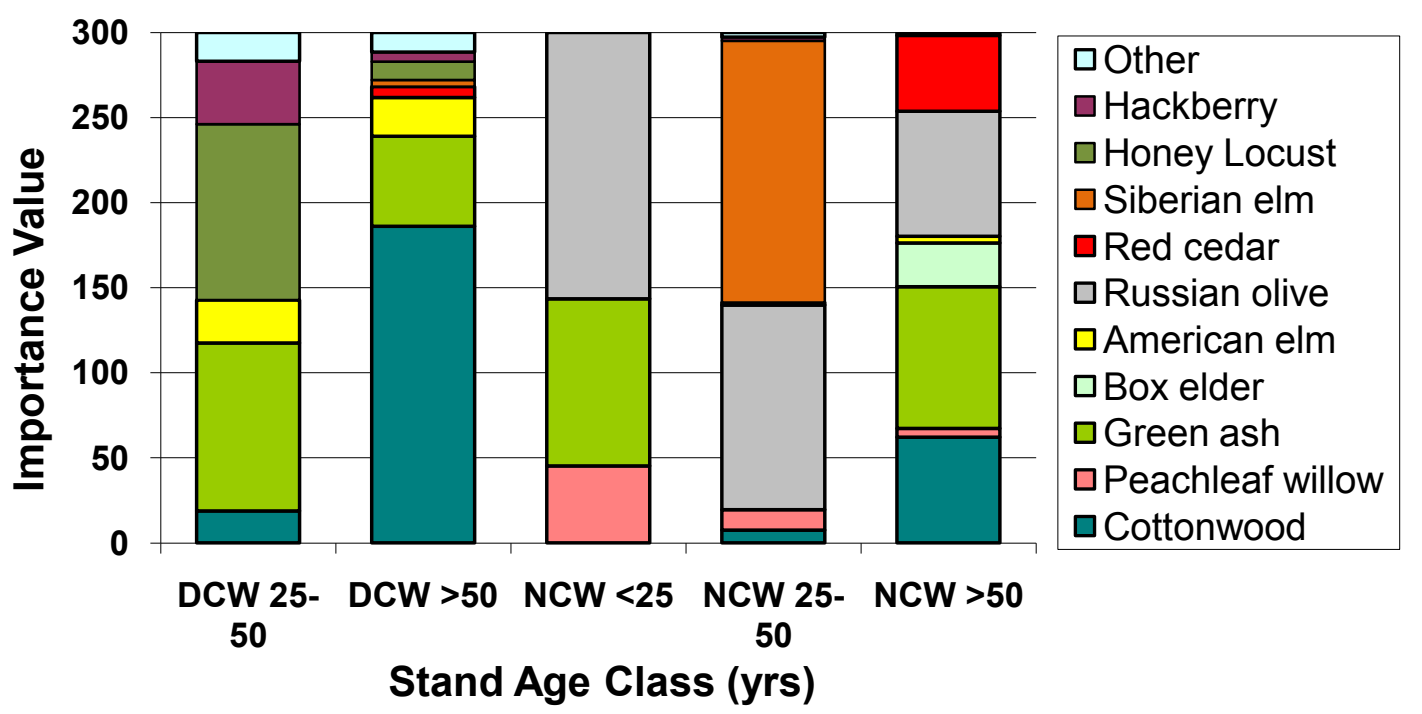

Figure 27b. Relative importance value (sum of relative frequency, density, and basal area) of different tree species within disturbed cottonwood and non-cottonwood forests in segment 6 . DCW refers to disturbed cottonwood stands and NCW refers to non-cottonwood stands. Data for DCW 2550 were based on a single stand. 
Cover of Shrub Species in Cottonwood Stands,

\section{Segment 6}

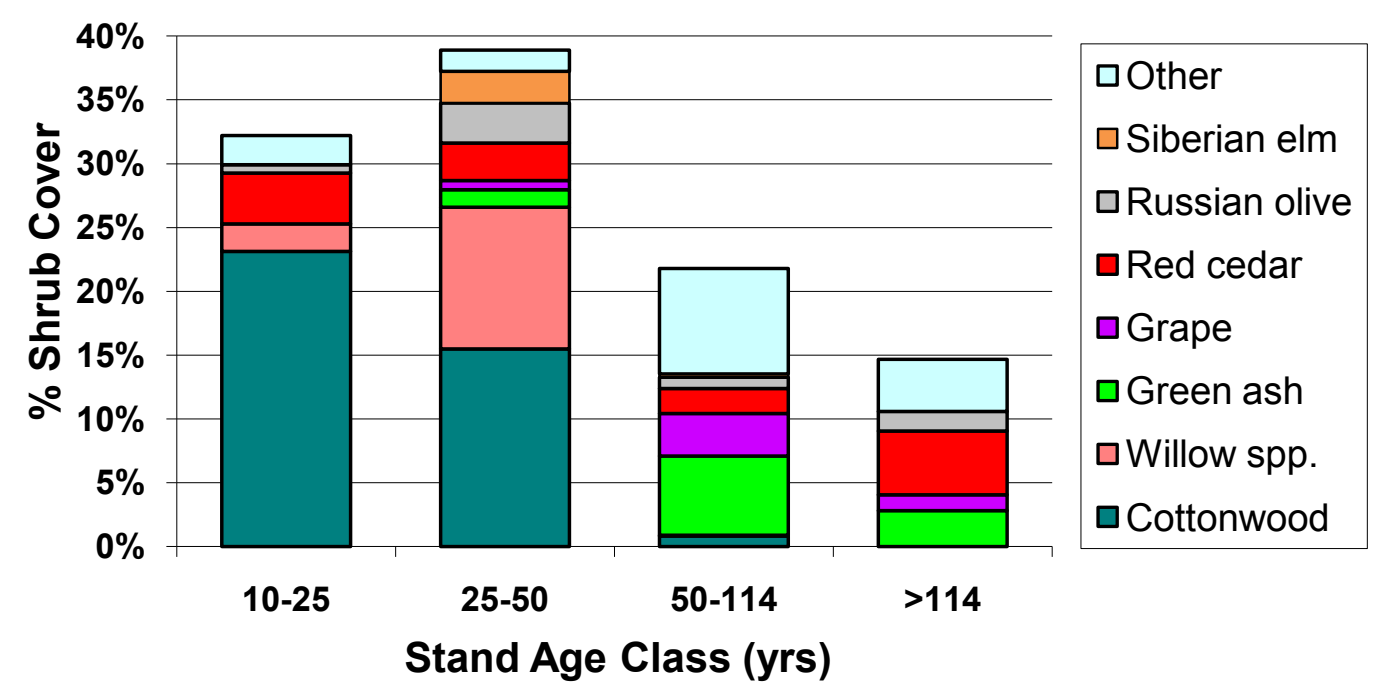

Figure 28a. Mean percent shrub cover by different species and overall mean shrub cover by cottonwood forest age class in segment 6 . Estimates of total shrub cover may be inflated because of overlapping cover of different species along the transect segments. No cottonwood stands $<10$ years old were located that were of sufficient size for sampling.

Cover of Shrub Species in Disturbed and Non-cottonwood Stands, Segment 6

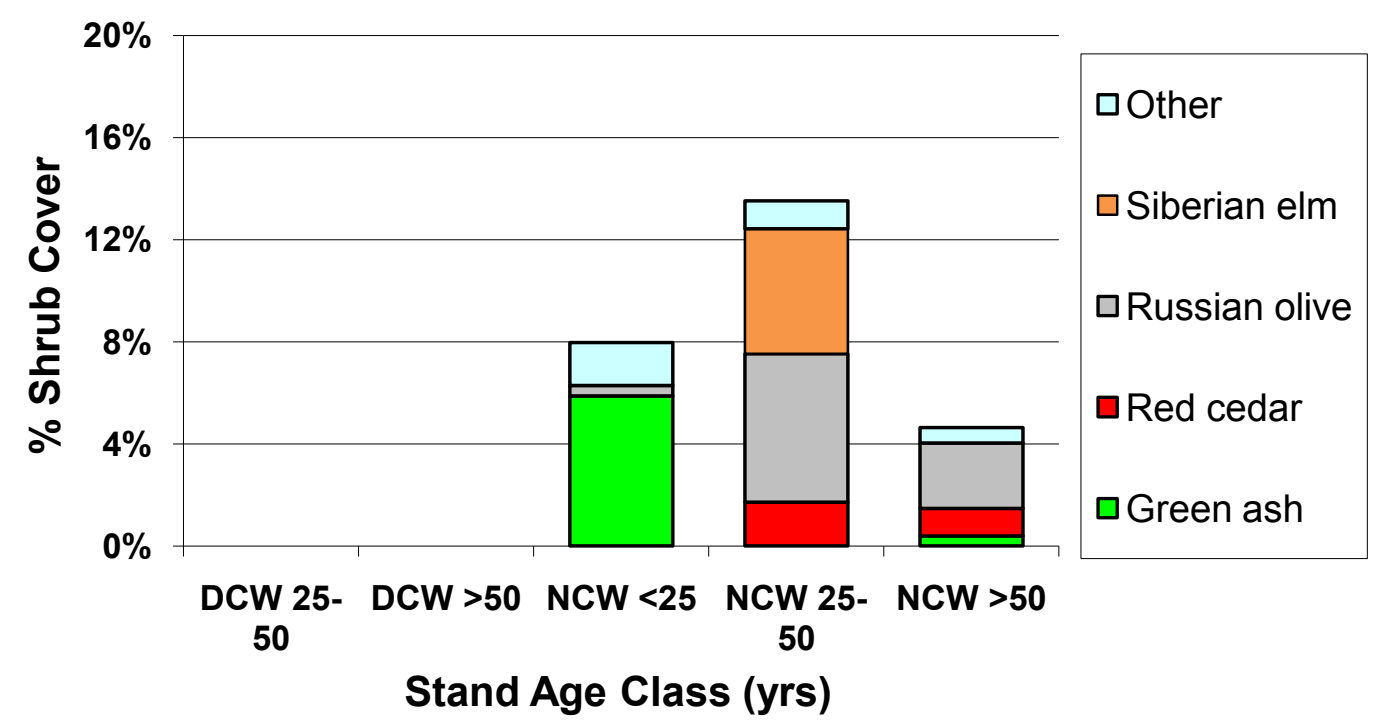

Figure 28b. Mean percent shrub cover by different species and overall mean shrub cover within non-cottonwood and disturbed cottonwood forests in segment 6 . Estimates of total shrub cover may be inflated because of overlapping cover of different species along the transect segments. DCW refers to disturbed cottonwood stands and NCW refers to non-cottonwood stands. Data for DCW 2550 were based on a single stand. 
Importance Value of Tree Species in Cottonwood Stands, Segment 4

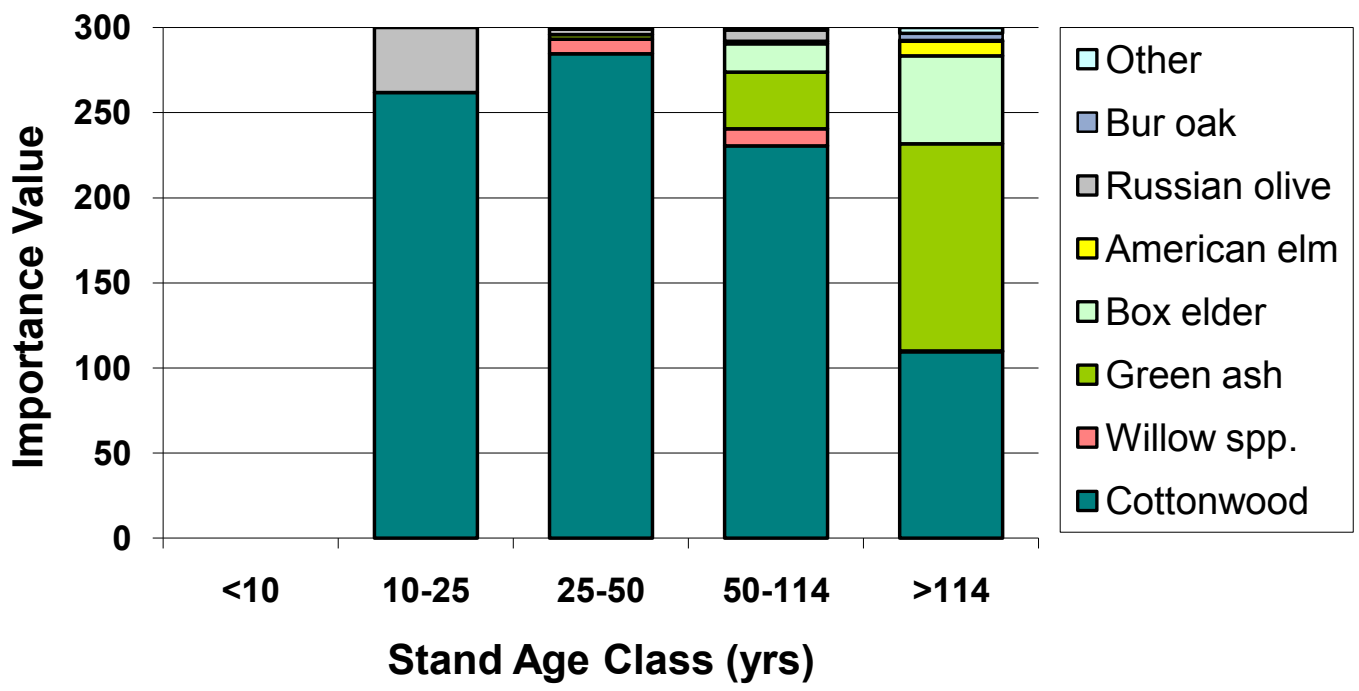

Figure 29a. Relative importance value (sum of relative frequency, density, and basal area) of different tree species by cottonwood forest age class in segment 4 . Sampled cottonwood stands $<10$ years old did not have any trees (stems $>10 \mathrm{~cm} \mathrm{dbh}$ ).

Importance Value of Tree Species in Disturbed and Non-cottonwood Stands, Segment 4

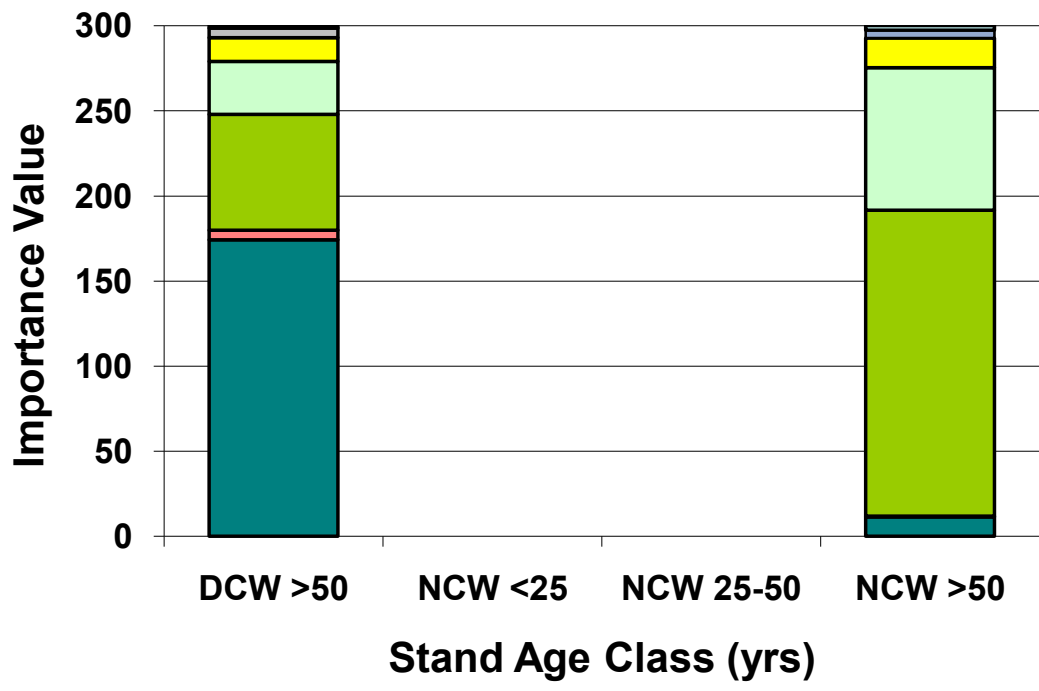

口Other

$\square$ Bur oak

口Russian olive

口American elm

口Box elder

$\square$ Green ash

口Willow spp.

口Cottonwood

Figure 29b. Relative importance value (sum of relative frequency, density, and basal area) of different tree species within disturbed cottonwood and non-cottonwood forests in segment 4 . DCW refers to disturbed cottonwood stands and NCW refers to non-cottonwood stands. Sampled NCW sites $<25$ and $25-50$ years old did not have any trees (stems $>10 \mathrm{~cm} \mathrm{dbh}$ ). 
Cover of Shrub Species in Cottonwood Stands,

\section{Segment 4}

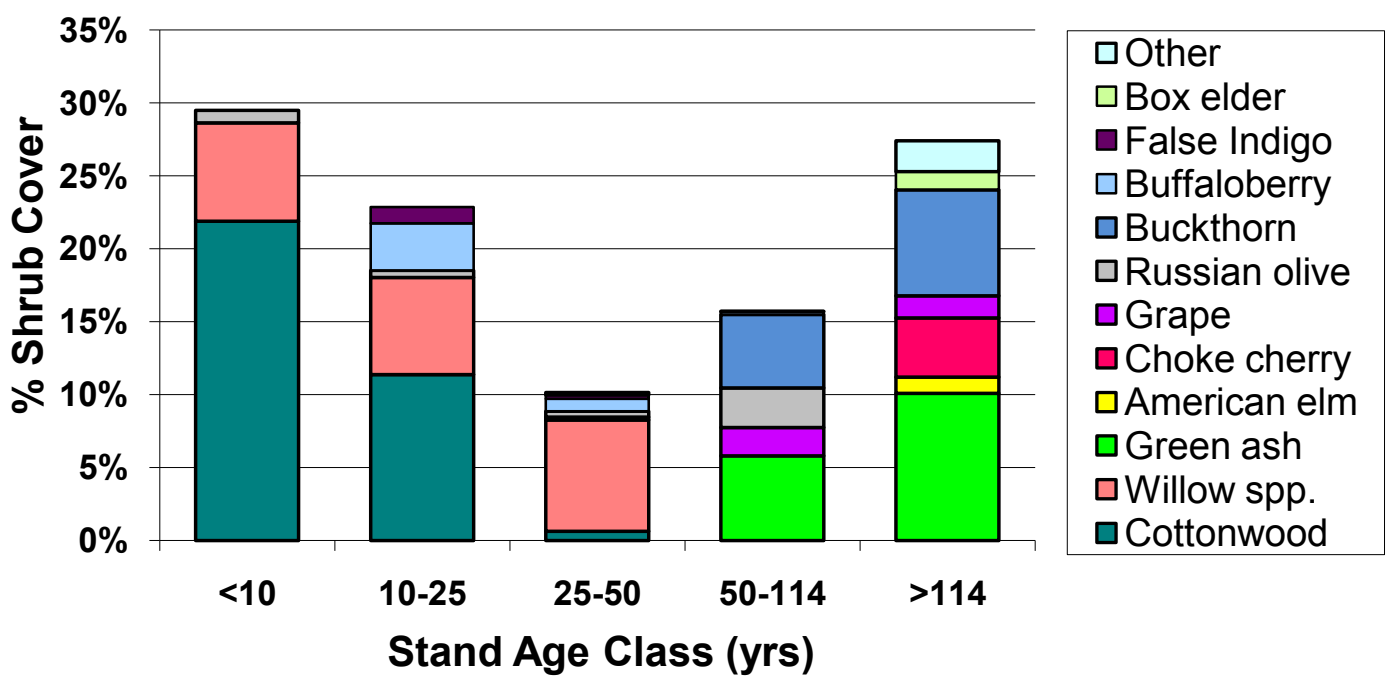

Figure 30a. Mean percent shrub cover by different species and overall mean shrub cover by cottonwood forest age class in segment 4 . Estimates of total shrub cover may be inflated because of overlapping cover of different species along the transect segments.

Cover of Shrub Species in Disturbed and Non-cottonwood Stands, Segment 4

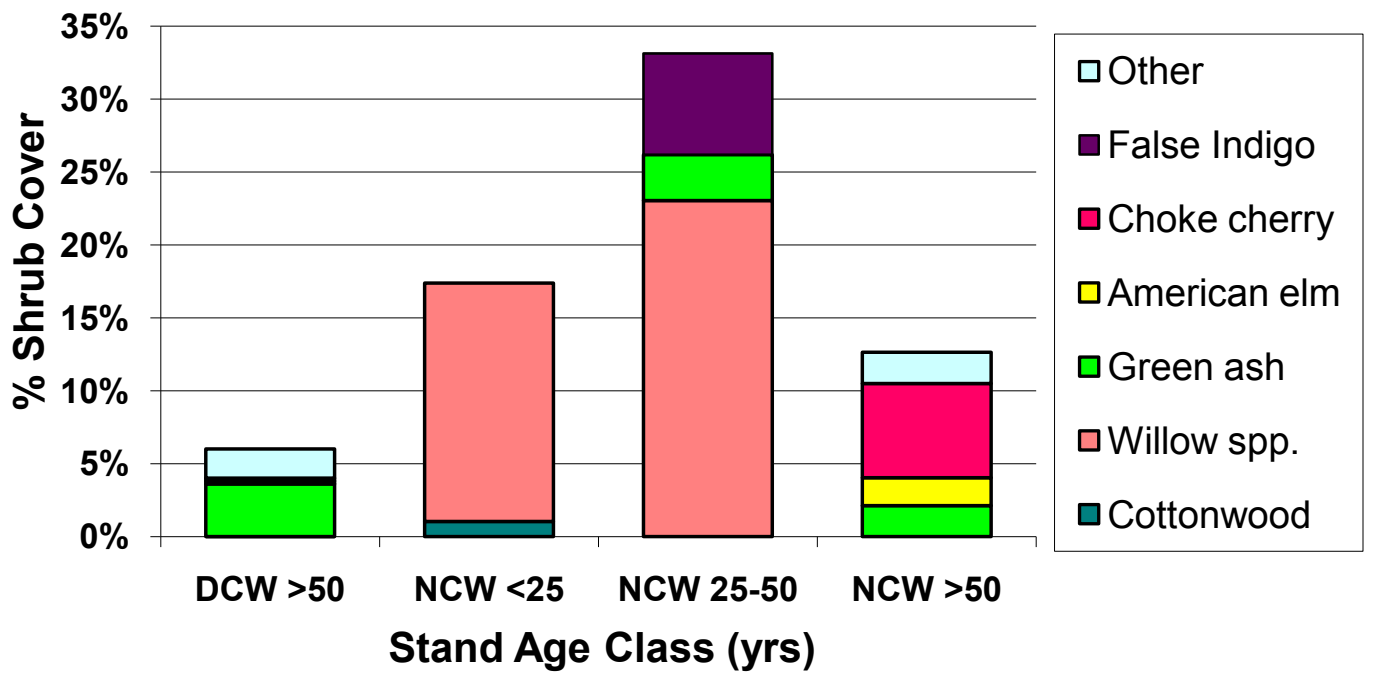

Figure 30b. Mean percent shrub cover by different species and overall mean shrub cover within non-cottonwood and disturbed cottonwood forests in segment 4 . Estimates of total shrub cover may be inflated because of overlapping cover of different species along the transect segments. DCW refers to disturbed cottonwood stands and NCW refers to non-cottonwood stands. Data for NCW 2550 were based on a single stand. 
Importance Value of Tree Species in Cottonwood Stands,

Segment 2

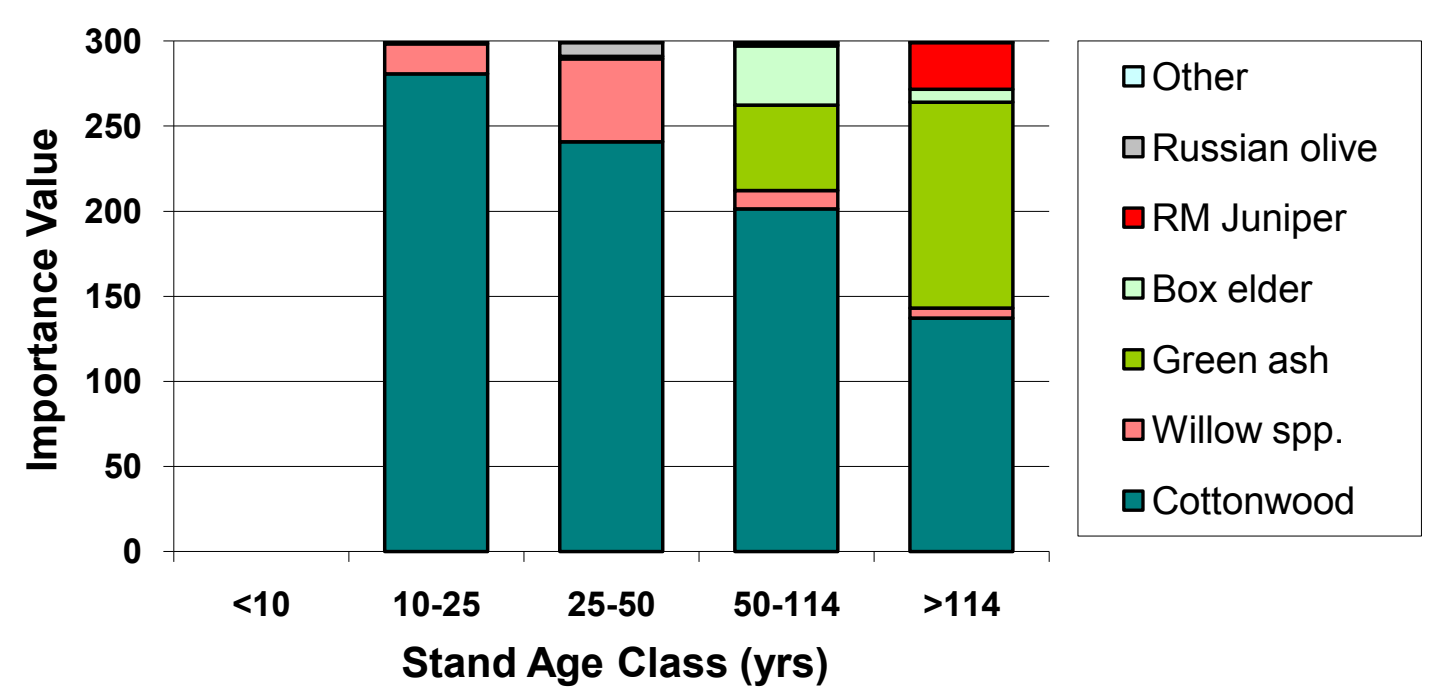

Figure 31. Relative importance value (sum of relative frequency, density, and basal area) of different tree species by cottonwood forest age class in segment 2 . Sampled cottonwood stands $<10$ years old did not have any trees (stems $>10 \mathrm{~cm} \mathrm{dbh}$ ).

Cover of Shrub Species in Cottonwood Stands, Segment 2

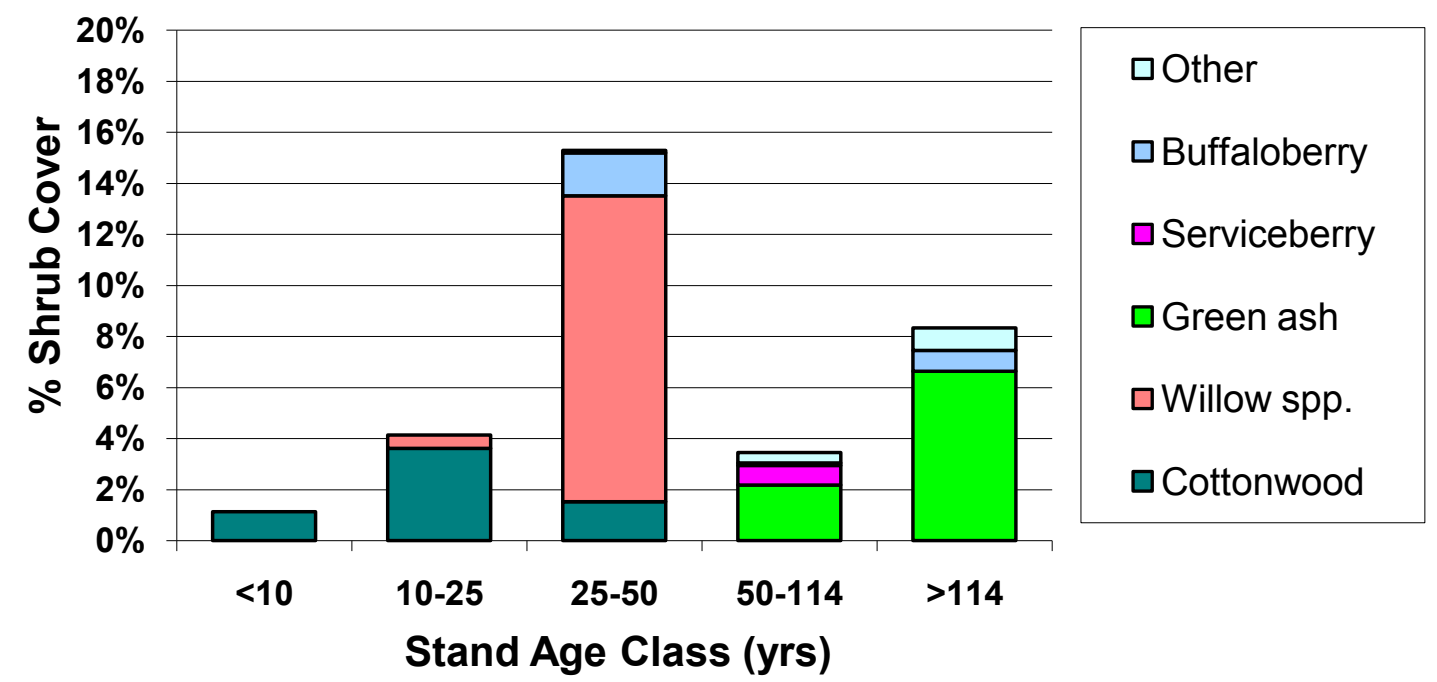

Figure 32. Mean percent shrub cover by different species and overall mean shrub cover by cottonwood forest age class in segment 2. Estimates of total shrub cover may be inflated because of overlapping cover of different species along the transect segments. 
Importance Value of Tree Species in Cottonwood Stands, Segment $\mathbf{0}$ (Wild and Scenic)

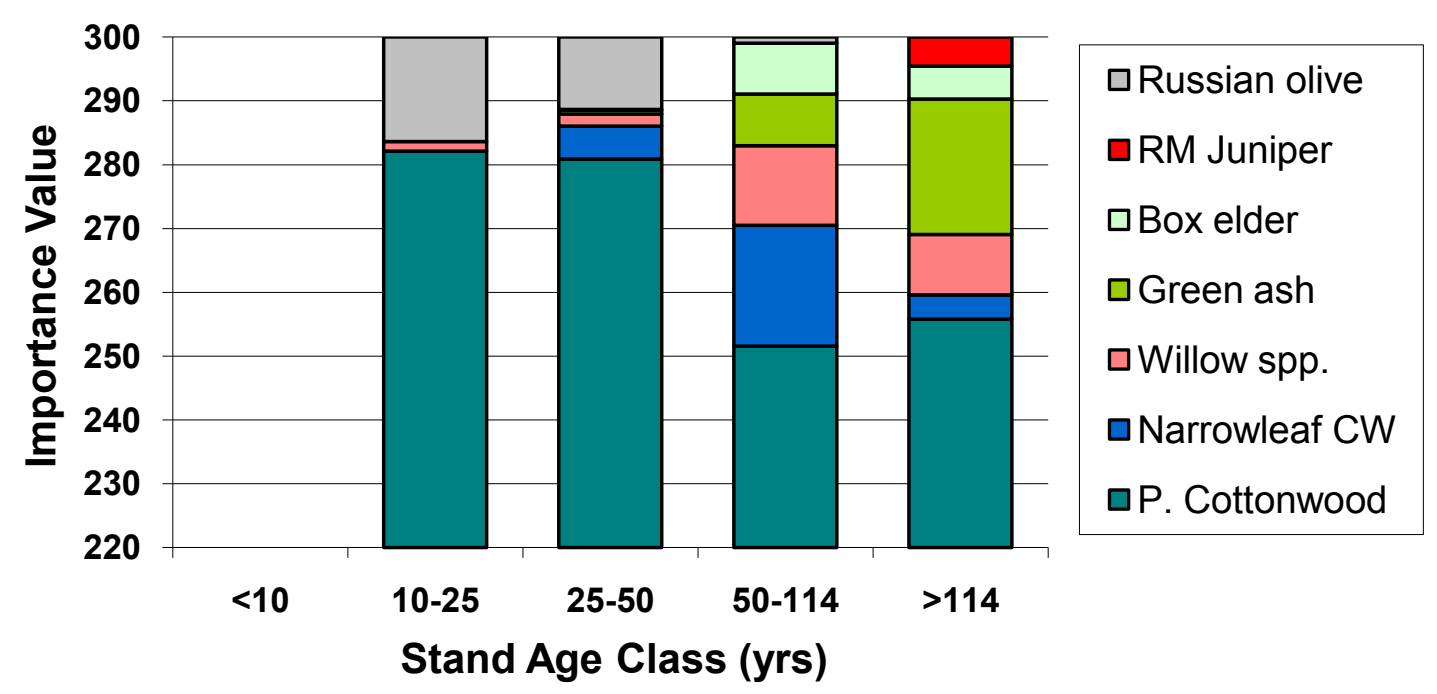

Figure 33. Relative importance value (sum of relative frequency, density, and basal area) of different tree species by cottonwood forest age class in segment 0 . Sampled cottonwood stands $<10$ years old did not have any trees (stems $>10 \mathrm{~cm} \mathrm{dbh}$ ).

\section{Cover of Shrub Species in Cottonwood Stands, Segment 0 (Wild and Scenic)}

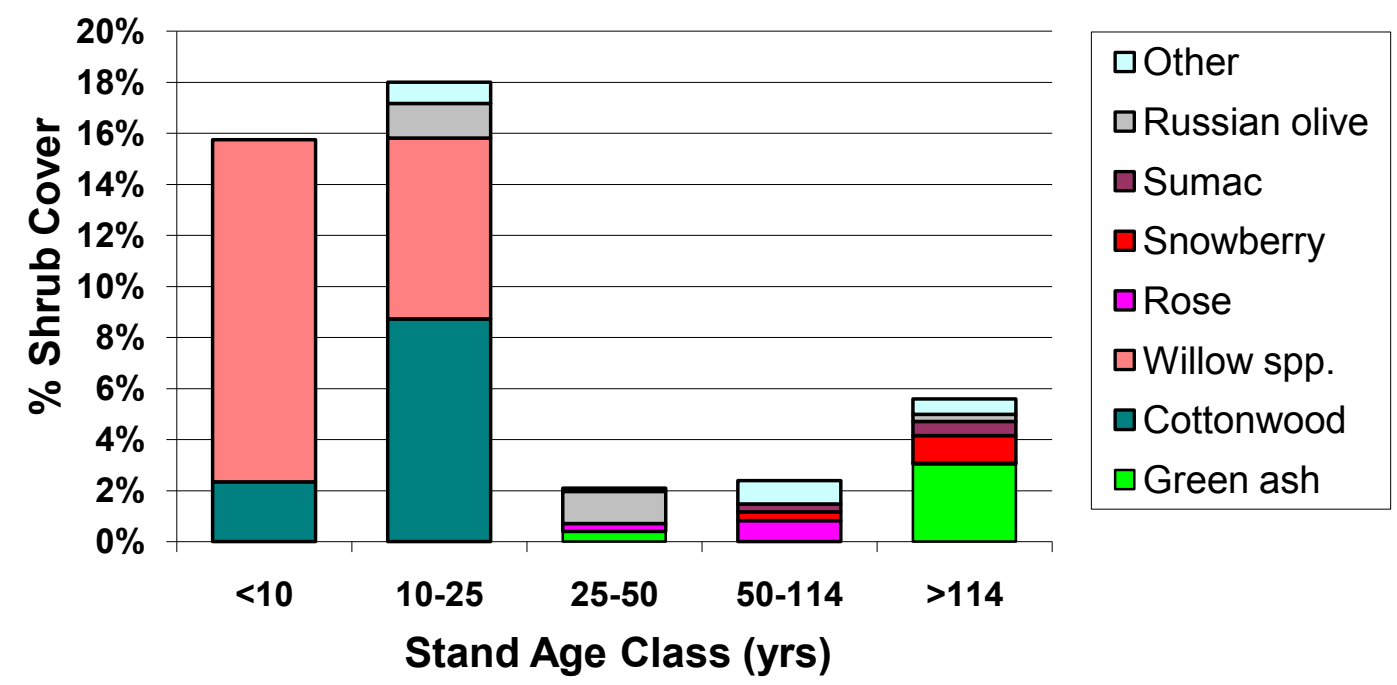

Figure 34. Mean percent shrub cover by different species and overall mean shrub cover by cottonwood forest age class in segment 0 . Estimates of total shrub cover may be inflated because of overlapping cover of different species along the transect segments. 


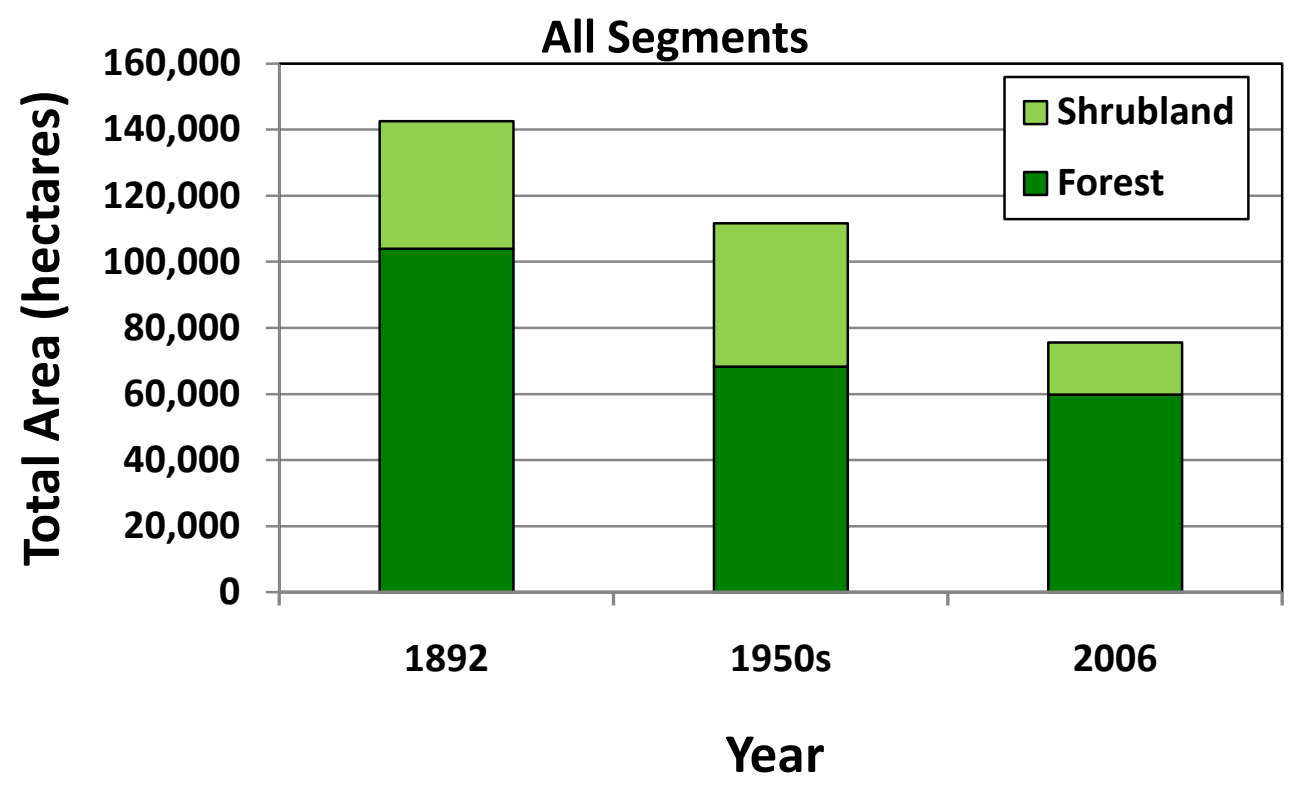

Figure 35. Composite changes in forest and shrubland area across all study segments from 1892 to the mid-1950s to 2006. Total area of natural woody vegetation declined $47 \%$ from 1892 to 2006 , with a $42 \%$ decline in forest and a $59 \%$ decline in shrubland. Note that most forest loss occurred between 1892 and the 1950s, while most shrubland loss occurred between the 1950s and 2006. 


\section{APPENDIX A: GIS Maps of Study Segments}

\section{Figure Captions:}

Figure A.1. Land cover maps for 1892, 1950s, and 2006, and forest age class map for segment 13 , subreach 1 (RM 595-518). Pink in 1892 map indicates undefined land cover in 1892 Missouri River Commission maps. Segment 13 is the channelized segment between Plattsmouth, NE and Kansas City, MO.

Figure A.2. Land cover maps for 1892, 1950s, and 2006, and forest age class map for segment 13 , subreach 2 (RM 518-440). Pink in 1892 map indicates undefined land cover in 1892 Missouri River Commission maps. Segment 13 is the channelized segment between Plattsmouth, NE and Kansas City, MO.

Figure A.3. Land cover maps for 1892, 1950s, and 2006, and forest age class map for segment 13 , subreach 3 (RM 440-365). Pink in 1892 map indicates undefined land cover in 1892 Missouri River Commission maps. Segment 13 is the channelized segment between Plattsmouth, NE and Kansas City, MO.

Figure A.4. Land cover maps for 1892, 1955-56, 1983-85, and 2006, and forest age class map for segment 10, subreach 1 (RM 811-792). Segment 10 is part (59-mile reach) of the Missouri National Recreational River, running between Yankton, SD (Gavins Point Dam) and Ponca, NE.

Figure A.5. Land cover maps for 1892, 1955-56, 1983-85, and 2006, and forest age class map for segment 10, subreach 2 (RM 792-772). Segment 10 is part (59-mile reach) of the Missouri National Recreational River, running between Yankton, SD (Gavins Point Dam) and Ponca, NE.

Figure A.6. Land cover maps for 1892, 1955-56, 1983-85, and 2006, and forest age class map for segment 10, subreach 3 (RM 772-753). Segment 10 is part (59-mile reach) of the Missouri National Recreational River, running between Yankton, SD (Gavins Point Dam) and Ponca, NE.

Figure A.7. Land cover maps for 1892, 1950s, and 2006, and forest age class map for segment 8 , subreach 1 (RM 880-867). Segment 8 is an inter-reservoir segment and is part (39-mile reach) of the Missouri National Recreational River, running between Pickstown, SD (Fort Randall Dam) and Niobrara, NE.

Figure A.8. Land cover maps for 1892, 1950s, and 2006, and forest age class map for segment 8 , subreach 2 (RM 867-854). Segment 8 is an inter-reservoir segment and is part (39-mile reach) of the Missouri National Recreational River, running between Pickstown, SD (Fort Randall Dam) and Niobrara, NE.

Figure A.9. Land cover maps for 1892, 1950s, and 2006, and forest age class map for segment 8 , subreach 3 (RM 854-841). Segment 8 is an inter-reservoir segment and is part (39-mile reach) of the Missouri National Recreational River, running between Pickstown, SD (Fort Randall Dam) and Niobrara, NE.

Figure A.10. Land cover maps for 1892, 1950s, and 2006, and forest age class map for segment 9 (RM 841-811). Segment 9 includes Lewis and Clark Reservoir and most of the delta that has formed in the lake downstream from the confluence with the Niobrara River.

Figure A.11. Land cover maps for 1892, 1950s, and 2006, and forest age class map for segment 6 , subreaches 1 and 2 (RM 1072-1054). Segment 6 begins at Oahe Dam, near Pierre, SD, and continues to Big Bend Dam, near Fort Thompson, SD, including all of Lake Sharpe.

Figure A.12. Land cover maps for 1892, 1950s, and 2006 for segment 6, subreach 3 (RM 1054987). Segment 6 begins at Oahe Dam, near Pierre, SD, and continues to Big Bend Dam, near Fort Thompson, SD, including all of Lake Sharpe. Subreach 3 is predominantly composed of Lake Sharpe. 
Figure A.13. Forest age class map for segment 6, subreach 3 (RM 1054-987). Segment 6 begins at Oahe Dam, near Pierre, SD, and continues to Big Bend Dam, near Fort Thompson, SD, including all of Lake Sharpe. Subreach 3 is predominantly composed of Lake Sharpe.

Figure A.14. Land cover maps for 1892, 1950s, and 2006, and forest age class map for segment 4, subreach 1 (RM 1390-1360). Segment 4 is an inter-reservoir segment, beginning at Garrison Dam and extending to the headwaters of Lake Oahe, southeast of Bismarck, ND.

Figure A.15. Land cover maps for 1892, 1950s, and 2006, and forest age class map for segment 4, subreach 2 (RM 1360-1333). Segment 4 is an inter-reservoir segment, beginning at Garrison Dam and extending to the headwaters of Lake Oahe, southeast of Bismarck, ND.

Figure A.16. Land cover maps for 1892, 1950s, and 2006, and forest age class map for segment 4, subreach 3 (RM 1333-1304). Segment 4 is an inter-reservoir segment, beginning at Garrison Dam and extending to the headwaters of Lake Oahe, southeast of Bismarck, ND.

Figure A.17. Land cover maps for 1892, 1950s, and 2006, and forest age class map for segment 4, subreach 4 (RM 1304-1286). Segment 4 is an inter-reservoir segment, beginning at Garrison Dam and extending to the headwaters of Lake Oahe, southeast of Bismarck, ND.

Figure A.18. Land cover maps for 1892, 1950s, and 2006, and forest age class map for segment 2, subreach 1 (RM 1771-1698). Segment 2 is an inter-reservoir segment, beginning at Fort Peck Dam in Montana and extending to the headwaters of Lake Sakakawea, near Williston, ND.

Figure A.19. Land cover maps for 1892, 1950s, and 2006, and forest age class map for segment 2, subreach 2 (RM 1698-1626). Segment 2 is an inter-reservoir segment, beginning at Fort Peck Dam in Montana and extending to the headwaters of Lake Sakakawea, near Williston, ND.

Figure A.20. Land cover maps for 1892, 1950s, and 2006, and forest age class map for segment 2, subreaches 3 and 4 (RM 1626-1543). Segment 2 is an inter-reservoir segment, beginning at Fort Peck Dam in Montana and extending to the headwaters of Lake Sakakawea, near Williston, ND. The confluence with the Yellowstone River marks the boundary between subreaches 3 and 4 .

Figure A.21. Land cover maps for 1892, 1950s, and 2006 for segment 0, subreach 1 (RM 20732027). Segment 0 extends from Fort Benton, MT to the headwaters of Fort Peck Lake, near the confluence with the Musselshell River. Much of the segment is designated a National Wild and Scenic River, within the Upper Missouri Breaks National Monument and Charles M. Russell National Wildlife Refuge.

Figure A.22. Forest age class map for segment 0, subreach 1 (RM 2073-2027). Segment 0 extends from Fort Benton, MT to the headwaters of Fort Peck Lake, near the confluence with the Musselshell River. Much of the segment is designated a National Wild and Scenic River, within the Upper Missouri Breaks National Monument and Charles M. Russell National Wildlife Refuge.

Figure A.23. Land cover maps for 1892, 1950s, and 2006, and forest age class map for segment 0 , upper $1 / 3$ of subreach 2 (RM 2027-2005). Segment 0 extends from Fort Benton, MT to the headwaters of Fort Peck Lake, near the confluence with the Musselshell River. Much of the segment is designated a National Wild and Scenic River, within the Upper Missouri Breaks National Monument and Charles M. Russell National Wildlife Refuge.

Figure A.24. Land cover maps for 1892, 1950s, and 2006, and forest age class map for segment 0 , middle $1 / 3$ of subreach 2 (RM 2005-1970). Segment 0 extends from Fort Benton, MT to the headwaters of Fort Peck Lake, near the confluence with the Musselshell River. Much of the segment is designated a National Wild and Scenic River, within the Upper Missouri Breaks National Monument and Charles M. Russell National Wildlife Refuge.

Figure A.25. Land cover maps for 1892, 1950s, and 2006, and forest age class map for segment 0 , lower $1 / 3$ of subreach 2 (RM 1970-1932). Segment 0 extends from Fort Benton, MT to the headwaters of Fort Peck Lake, near the confluence with the Musselshell River. Much of the segment is designated a National Wild and Scenic River, within the Upper Missouri Breaks National Monument 
and Charles M. Russell National Wildlife Refuge.

Figure A.26. Land cover maps for 1892, 1950s, and 2006 for segment 0, subreach 3 (RM 19321917). Segment 0 extends from Fort Benton, MT to the headwaters of Fort Peck Lake, near the confluence with the Musselshell River. Much of the segment is designated a National Wild and Scenic River, within the Upper Missouri Breaks National Monument and Charles M. Russell National Wildlife Refuge.

Figure A.27. Forest age class map for segment 0, subreach 3 (RM 1932-1917). Segment 0 extends from Fort Benton, MT to the headwaters of Fort Peck Lake, near the confluence with the Musselshell River. Much of the segment is designated a National Wild and Scenic River, within the Upper Missouri Breaks National Monument and Charles M. Russell National Wildlife Refuge. 
Figure A.1 - Segment 13, Subreach 1 (RM 595 - 518)

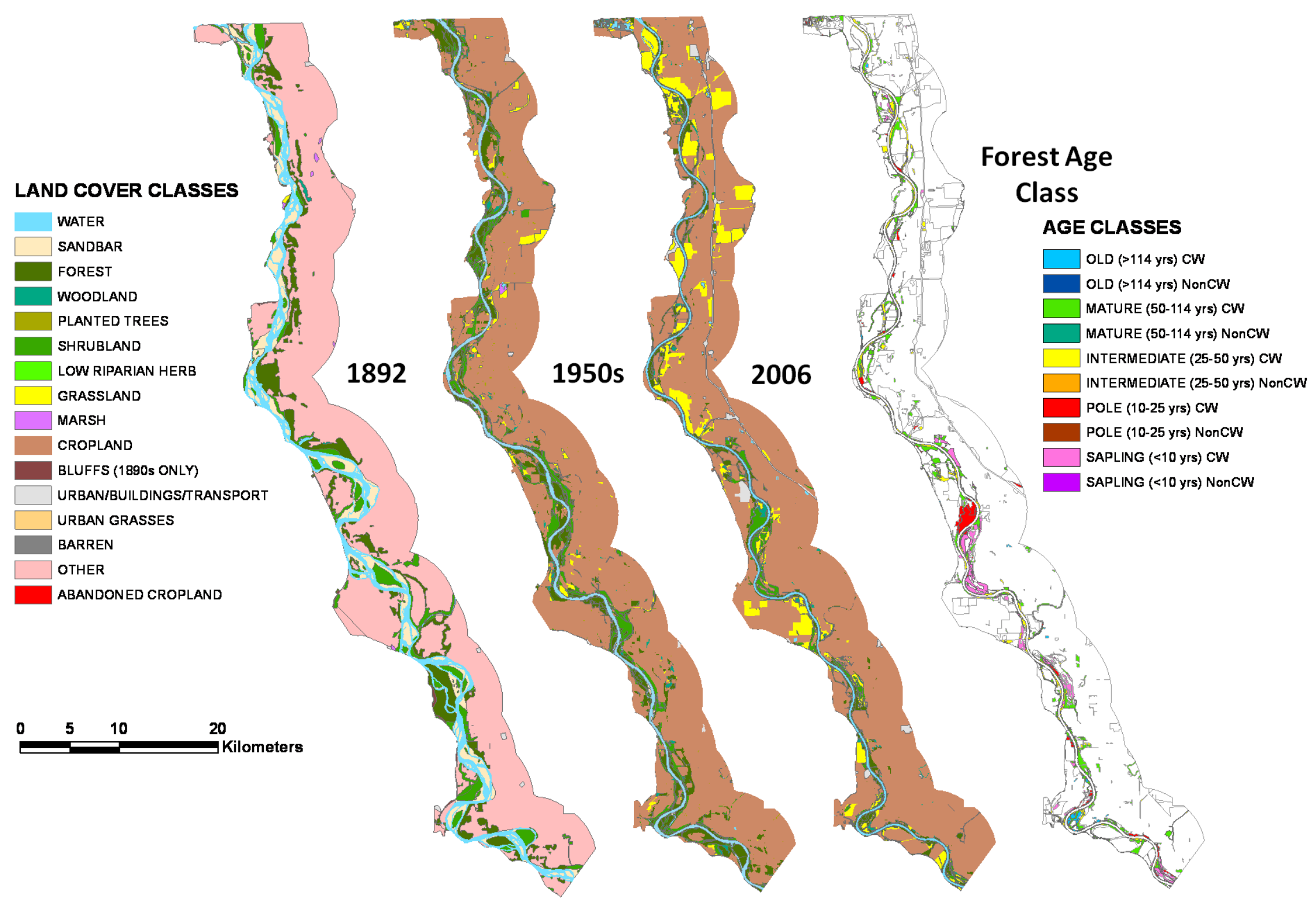




\section{Figure A.2 - Segment 13, Subreach 2 (RM 518 - 440)}

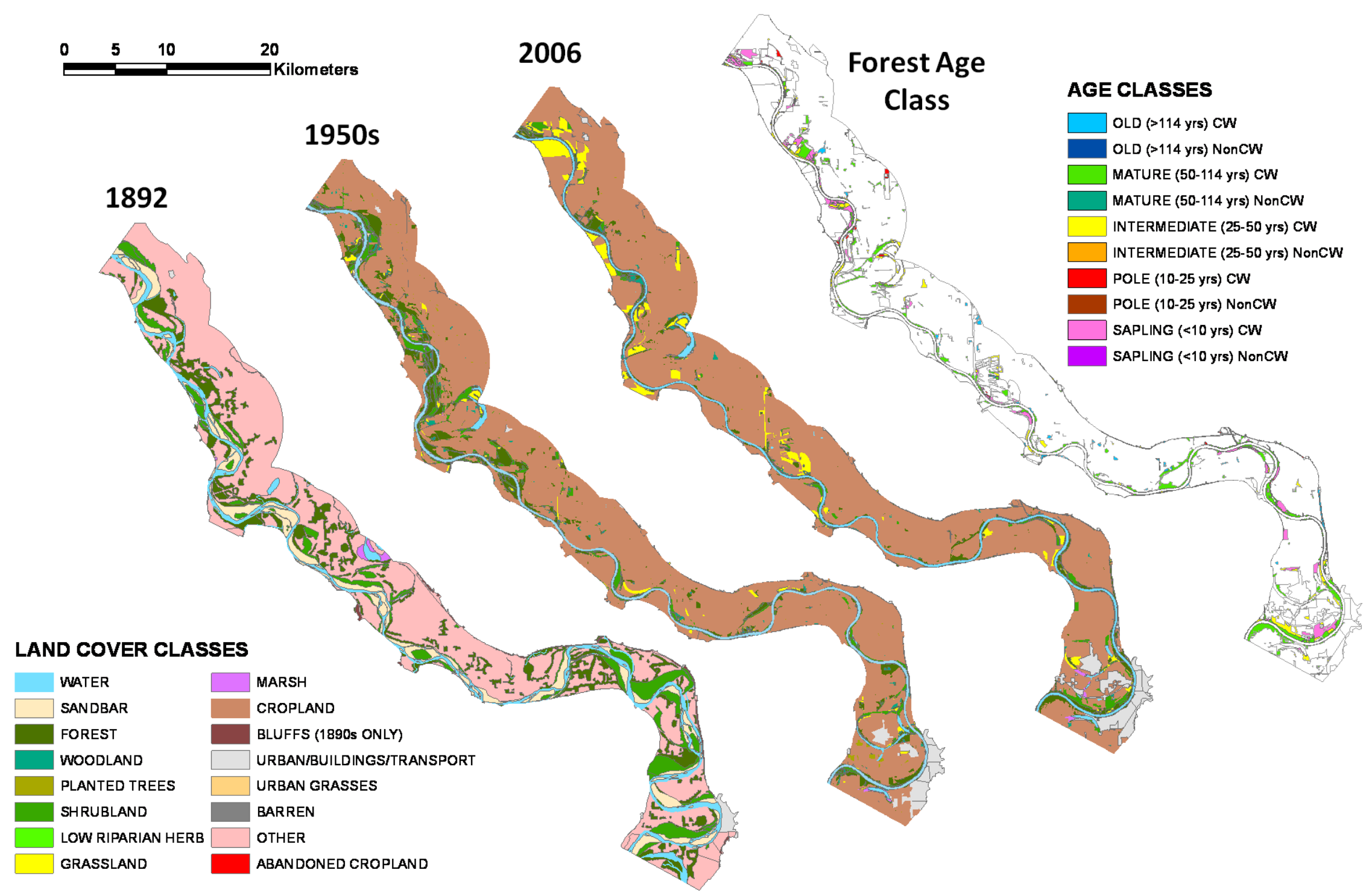




\section{Figure A.3 - Segment 13, Subreach 3 (RM 440 - 365)}

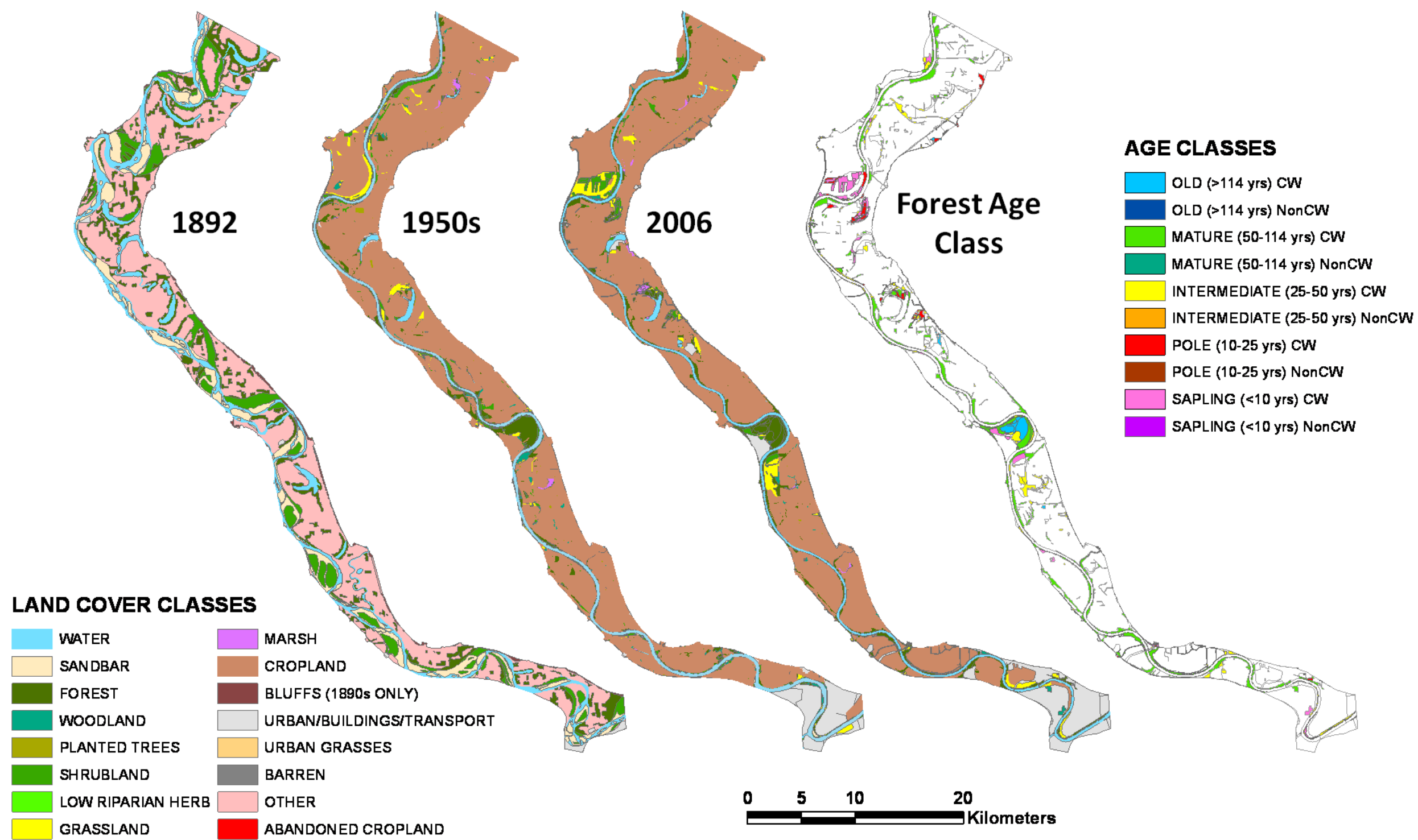


Figure A.4 - Segment 10, Subreach 1 (RM 811 - 792)

1892

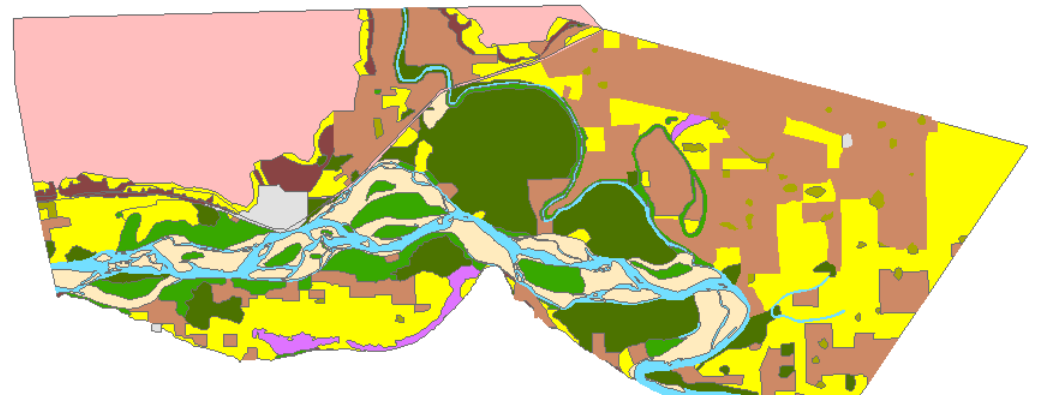

1983-85

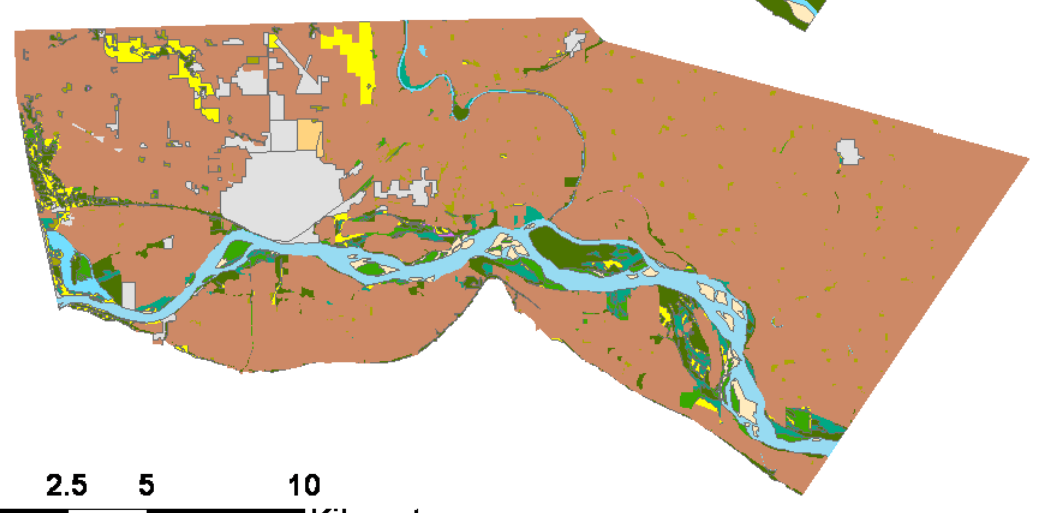

\section{LAND COVER CLASSES}

\begin{tabular}{|c|c|}
\hline WATER & MARSH \\
\hline SANDBAR & CROPLAND \\
\hline FOREST & BLUFFS (1890s ONLY) \\
\hline WOODLAND & URBAN/BUILDINGS/TRANSPORT \\
\hline PLANTED TREES & URBAN GRASSES \\
\hline SHRUBLAND & BARREN \\
\hline LOW RIPARIAN HERB & OTHER \\
\hline GRASSLAND & ABANDONED CROPLAND \\
\hline
\end{tabular}

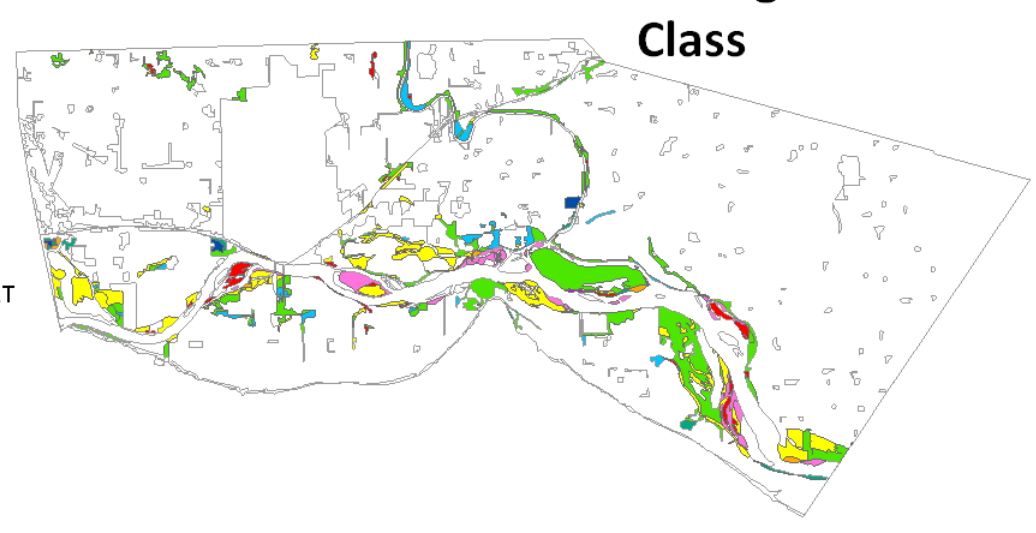

\section{AGE CLASSES}

$\square$ OLD ( $>114 \mathrm{yrs}) \mathrm{CW}$

OLD (>114 yrs) NonCW

MATURE (50-114 yrs) CW

MATURE (50-114 yrs) NonCW INTERMEDIATE (25-50 yrs) cW

INTERMEDIATE (25-50 yrs) NonCW

POLE (10-25 yrs) CW

POLE (10-25 yrs) NonCW SAPLING $(<10 \mathrm{yrs}) \mathrm{CW}$ SAPLING ( $<10 \mathrm{yrs})$ NonCW 
Figure A.5 - Segment 10, Subreach 2 (RM 792 - 772)

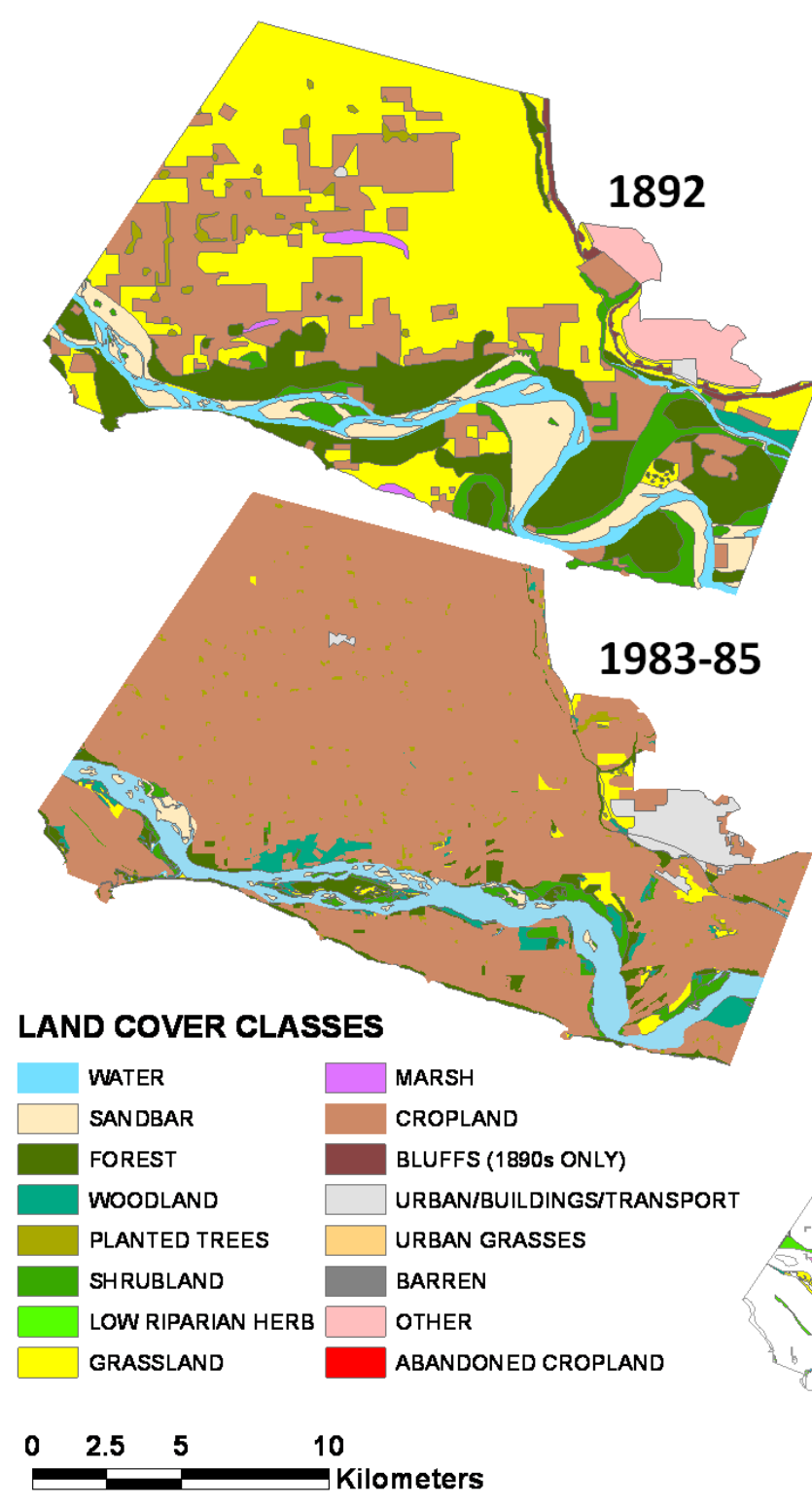

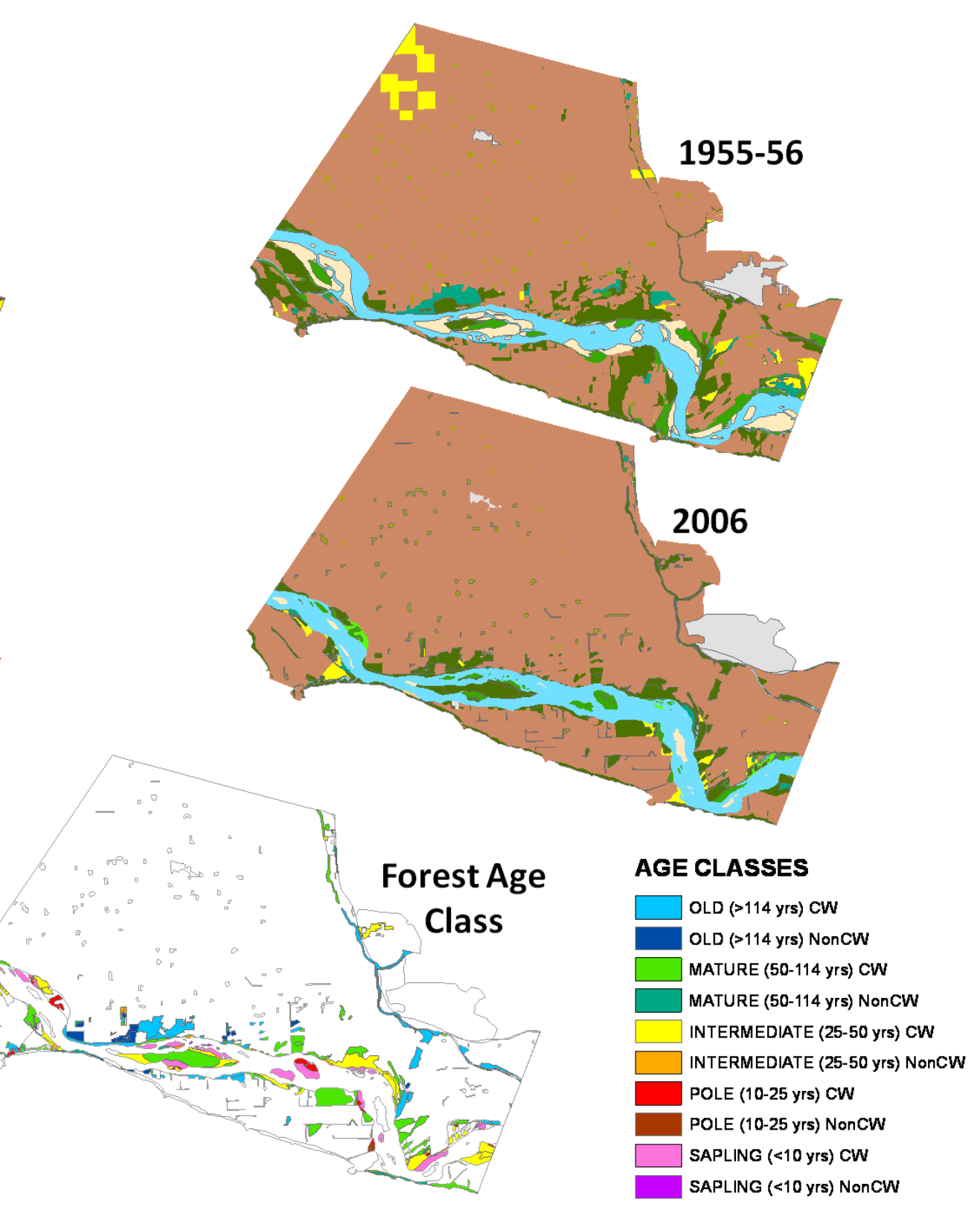


Figure A.6 - Segment 10, Subreach 3 (RM 772 - 753)
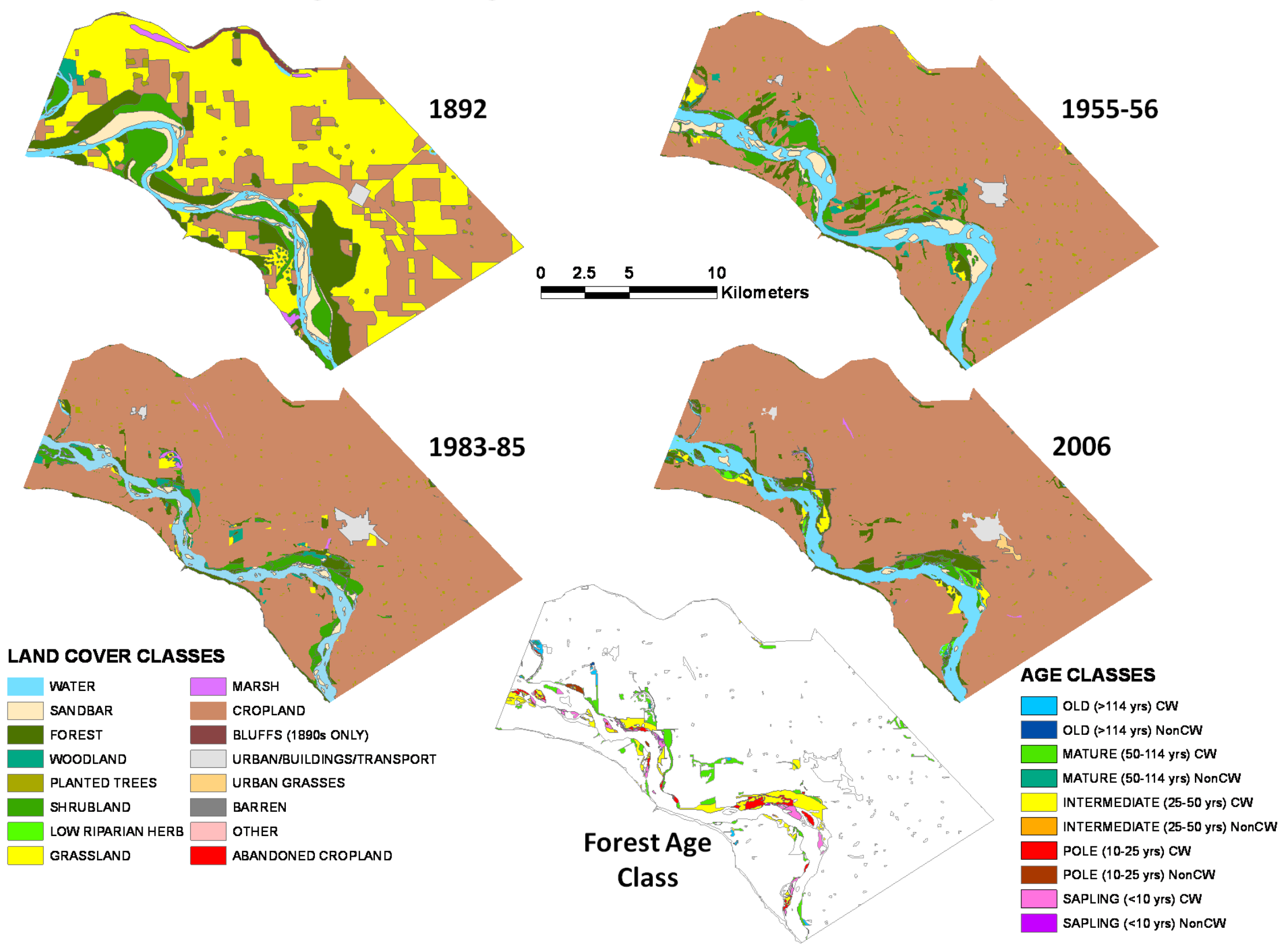
Figure A.7 - Segment 8, Subreach 1 (RM 880 - 867)

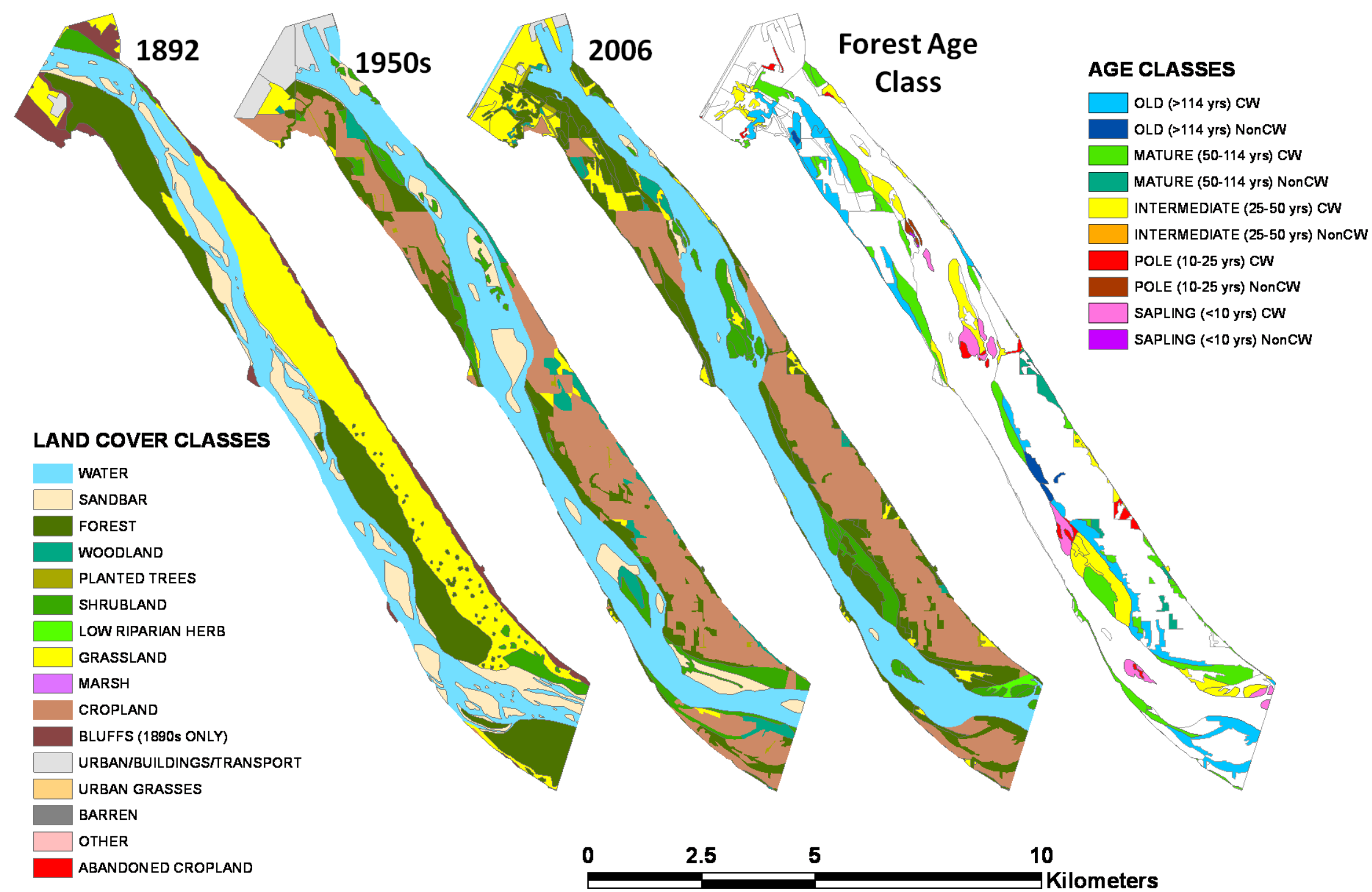




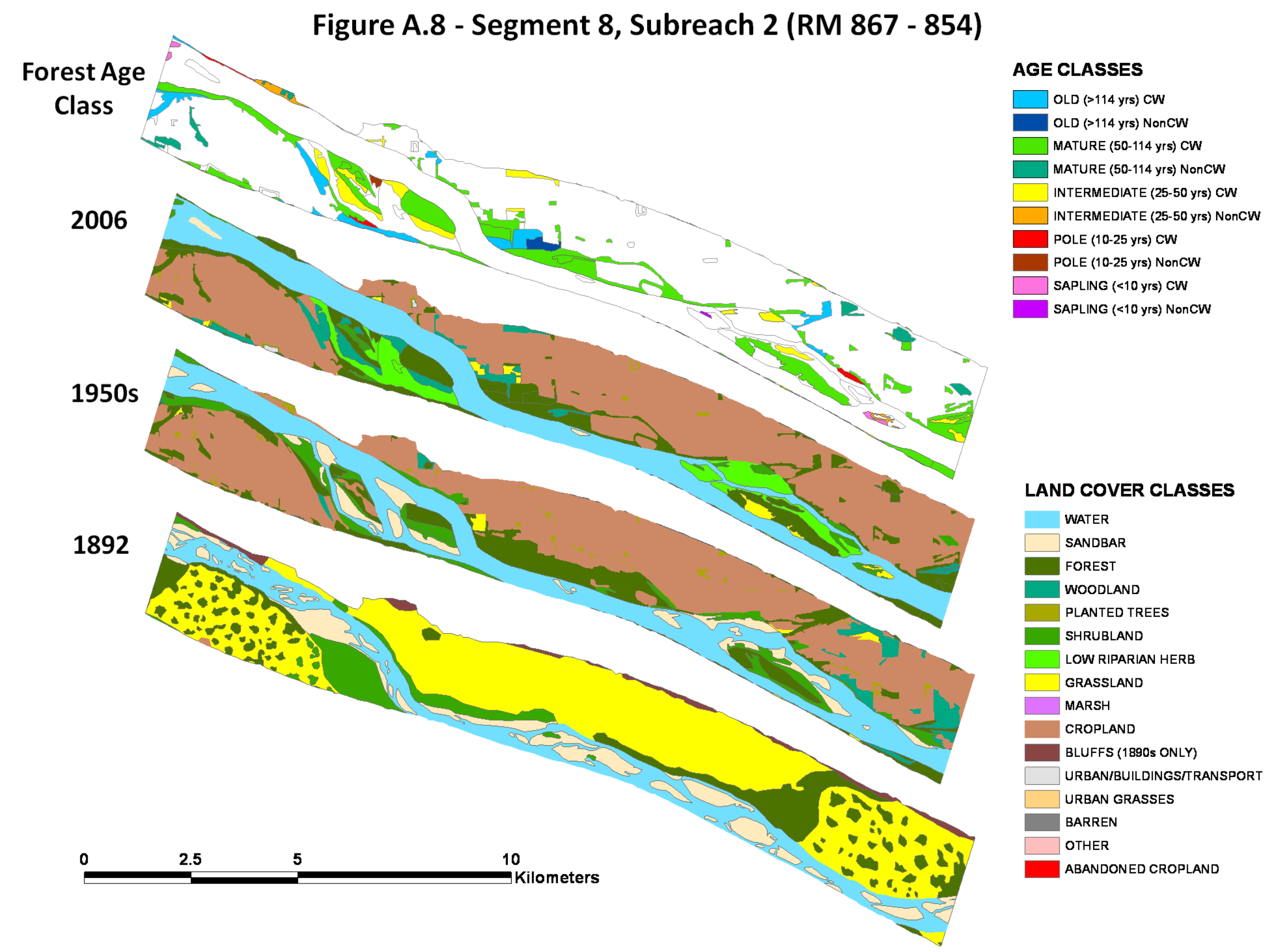


Figure A.9 - Segment 8, Subreach 3 (RM 854 - 841)

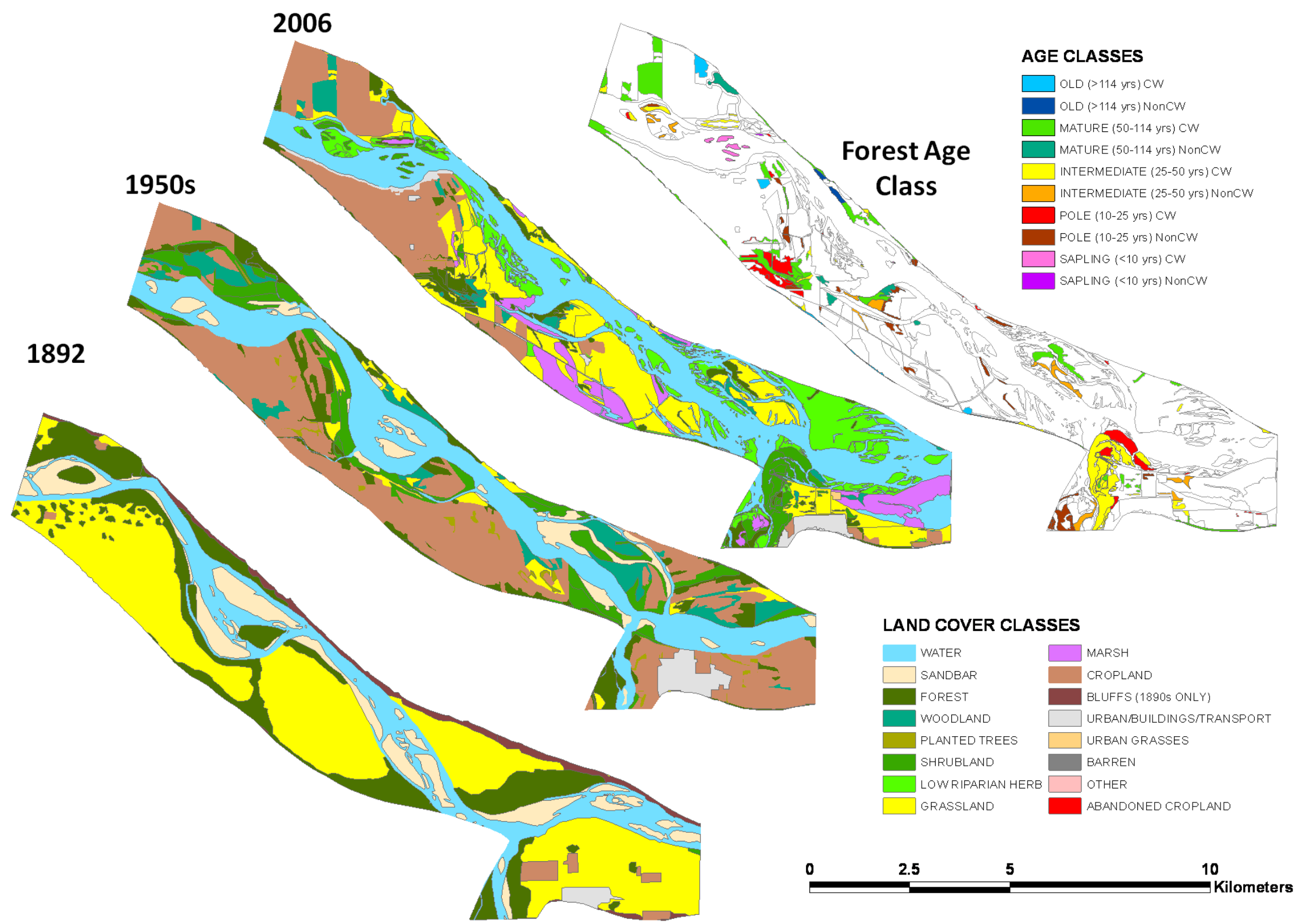




\section{Figure A.10 - Segment 9 (RM 841 - 811)}

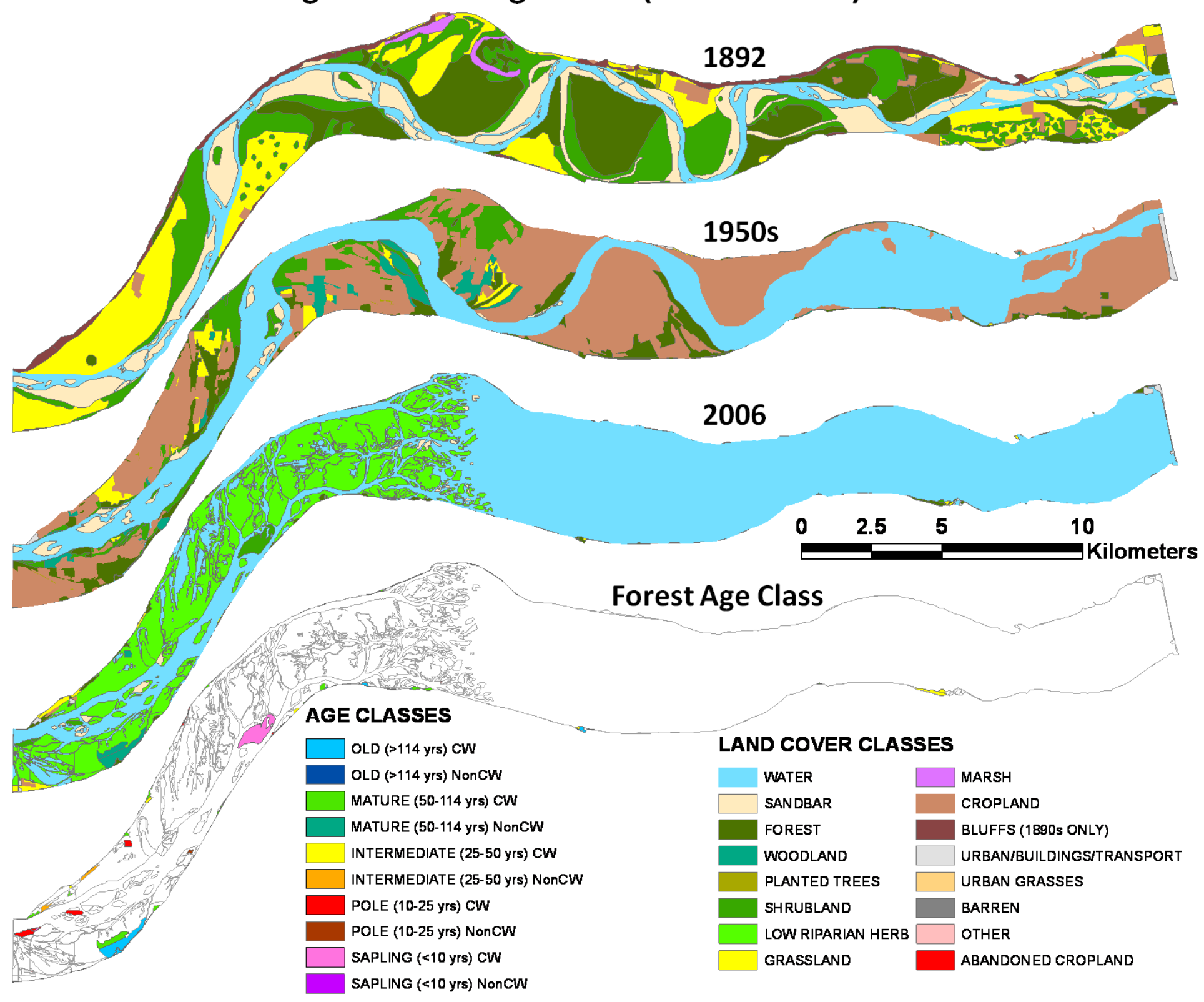


Figure A.11 - Segment 6, Subreaches 1 \& 2 (RM 1072-1054)

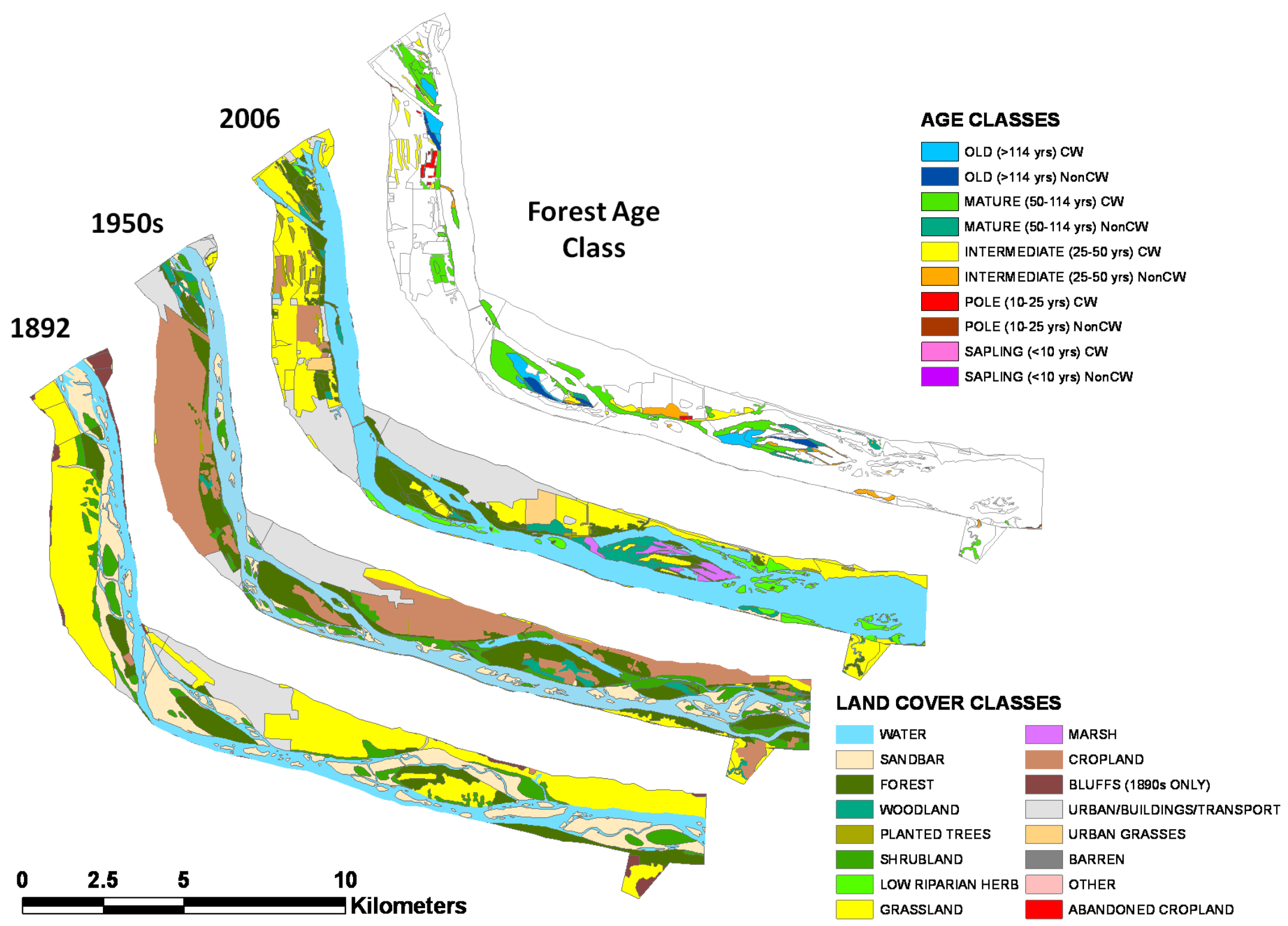


Figure A.12 - Segment 6, Subreach 3 (RM 1054 - 987)

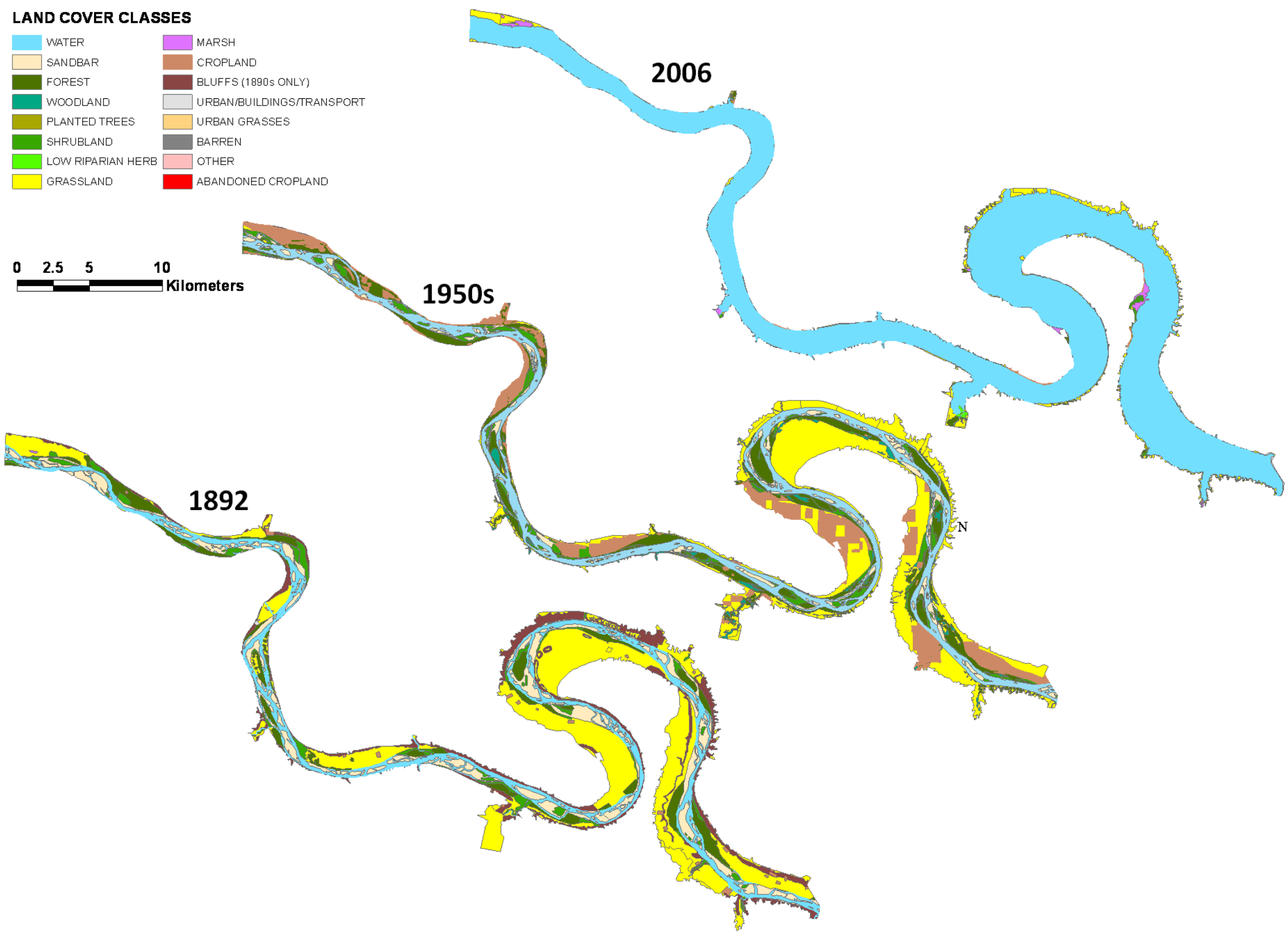


Figure A.13 - Segment 6, Subreach 3 (RM 1054 - 987)

AGE CLASSES

$\square$ OLD $(>114 \mathrm{yrs}) \mathrm{CW}$ OLD ( $>114$ yrs) NonCW MATURE (50-114 yrs) CW MATURE (50-114 yrs) NonCW INTERMEDIATE (25-50 yrs) CW INTERMEDIATE (25-50 yrs) NonCW POLE (10-25 yrs) CW POLE (10-25 yrs) NonCW SAPLING ( $<10 \mathrm{yrs}) \mathrm{CW}$ SAPLING (<10 yrs) NonCW

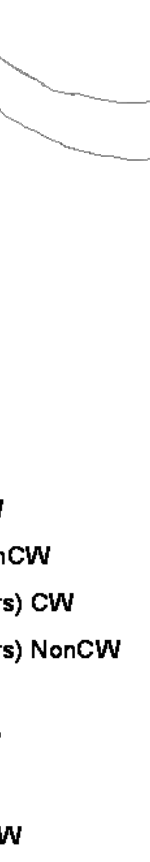

$\begin{array}{lll}0 & 2.55\end{array}$ 
Figure A.14 - Segment 4, Subreach 1 (RM 1390 - 1360)
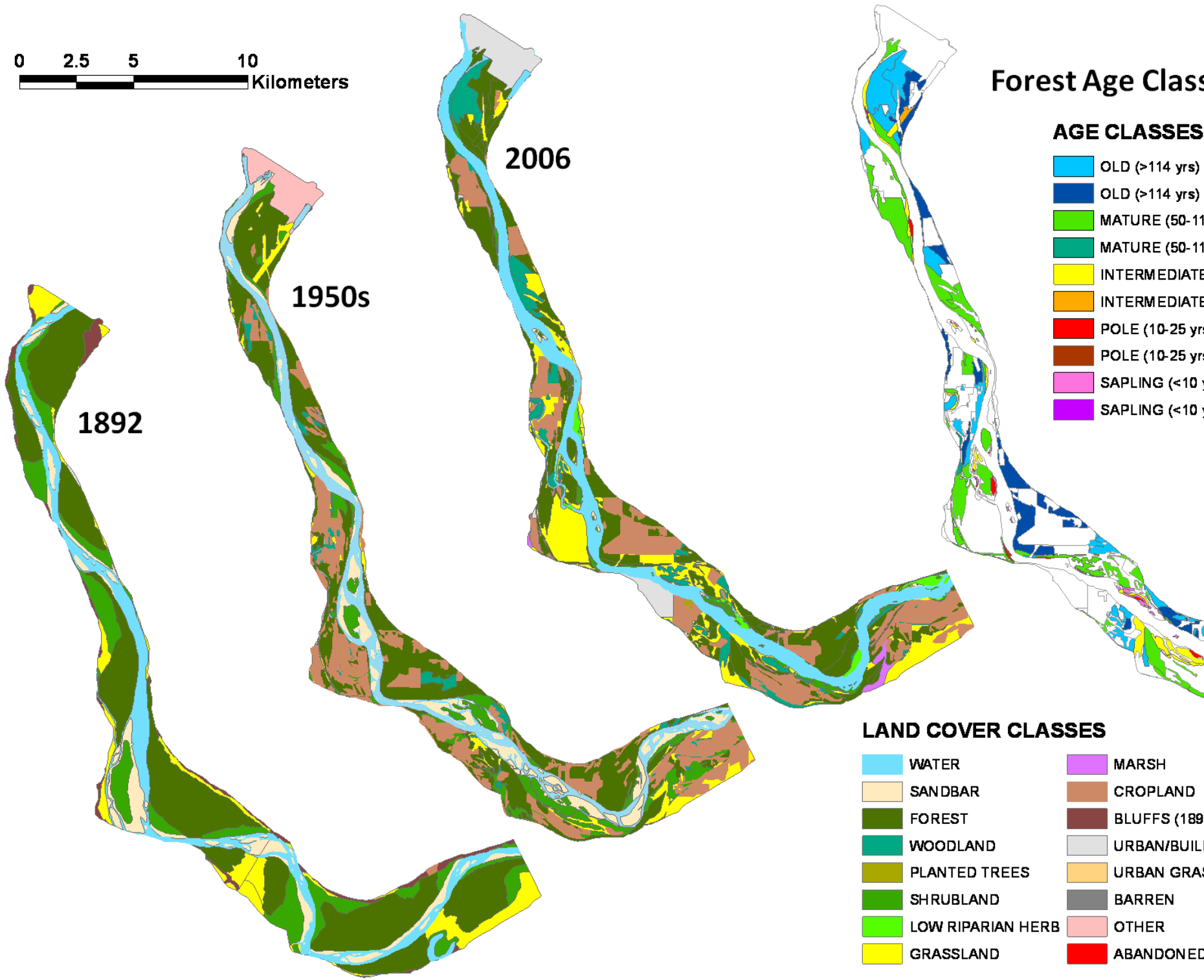

AGE CLASSES

$\square$ OLD (>114 yrs) CW

OLD ( $>114$ yrs) NoncW

$\square$ MATURE (50-114 yrs) CW

MATURE (50-114 yrs) NonCW

INTERMEDIATE (25-50 yrs) CW

INTERMEDIATE (25-50 yrs) NonCW

POLE (10-25 yrs) CW

POLE (10-25 yrs) NonCW

SAPLING (<10 yrs) CW

SAPLING (<10 yrs) NoncW

\section{LAND COVER CLASSES}

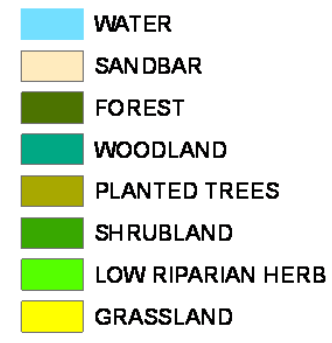

\begin{tabular}{|l|l}
\hline & MARSH \\
CROPLAND \\
BLUFFS (1890s ONLY) \\
\hline URBAN/BUILDINGS/TRANSPORT \\
\hline URBAN GRASSES \\
BARREN \\
OTHER \\
ABANDONED CROPLAND
\end{tabular}


Figure A.15 - Segment 4, Subreach 2 (RM 1360 - 1333)

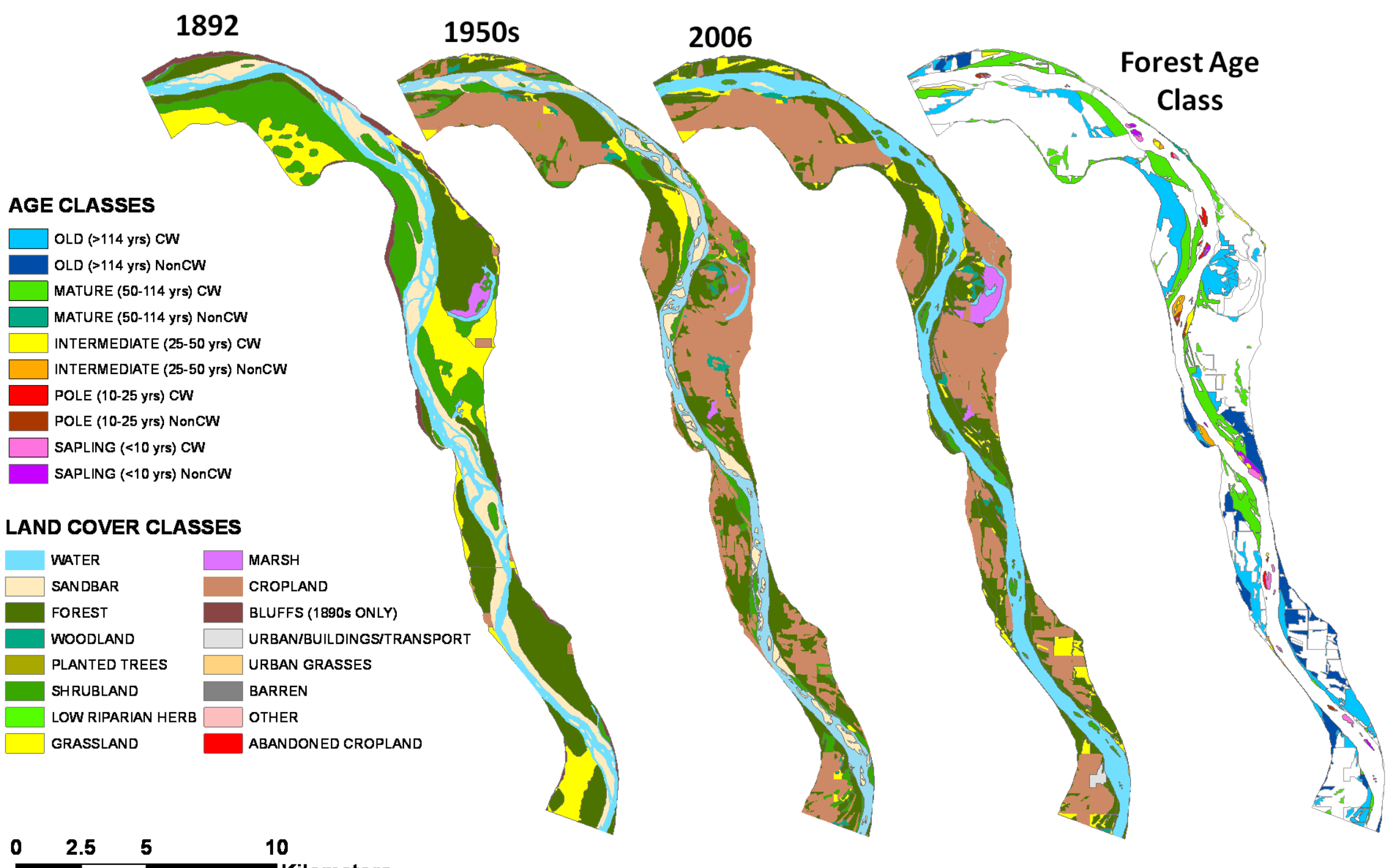


Figure A.16 - Segment 4, Subreach 3 (RM 1333 - 1304)

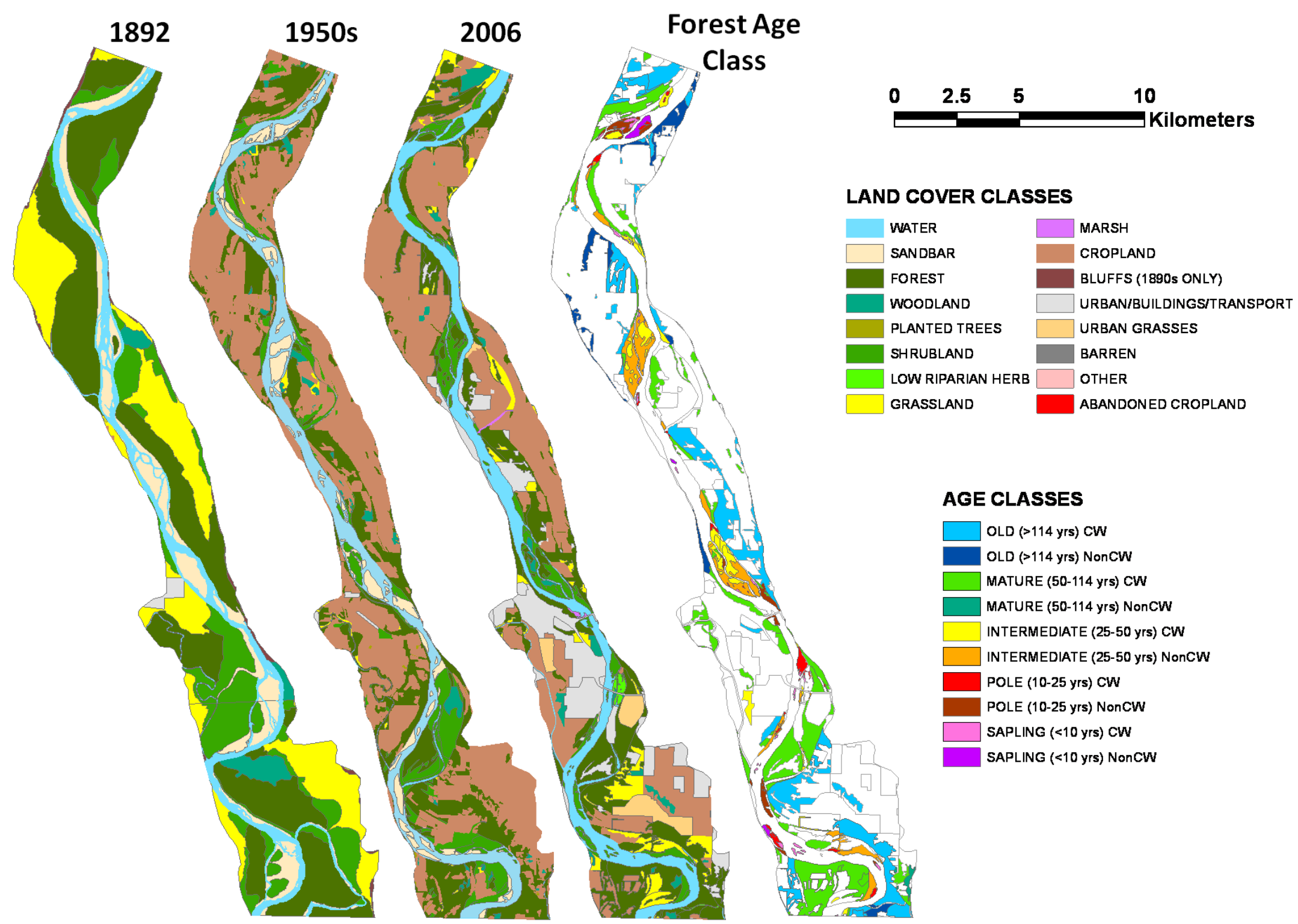


Figure A.17 - Segment 4, Subreach 4 (RM 1304 - 1286)

\section{LAND COVER CLASSES}

\section{Forest Age Class}

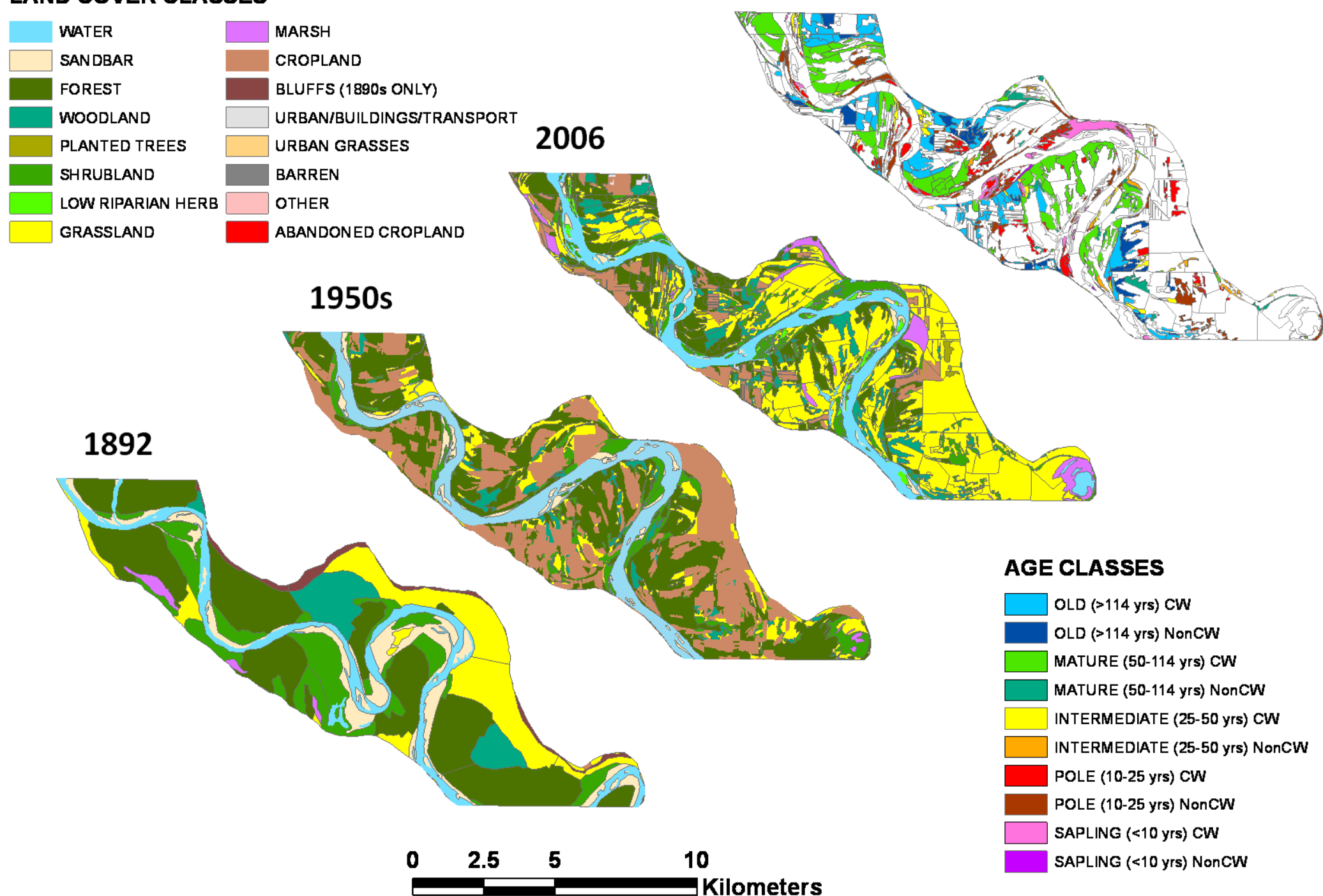


Figure A.18 - Segment 2, Subreach 1 (RM 1771 - 1698)

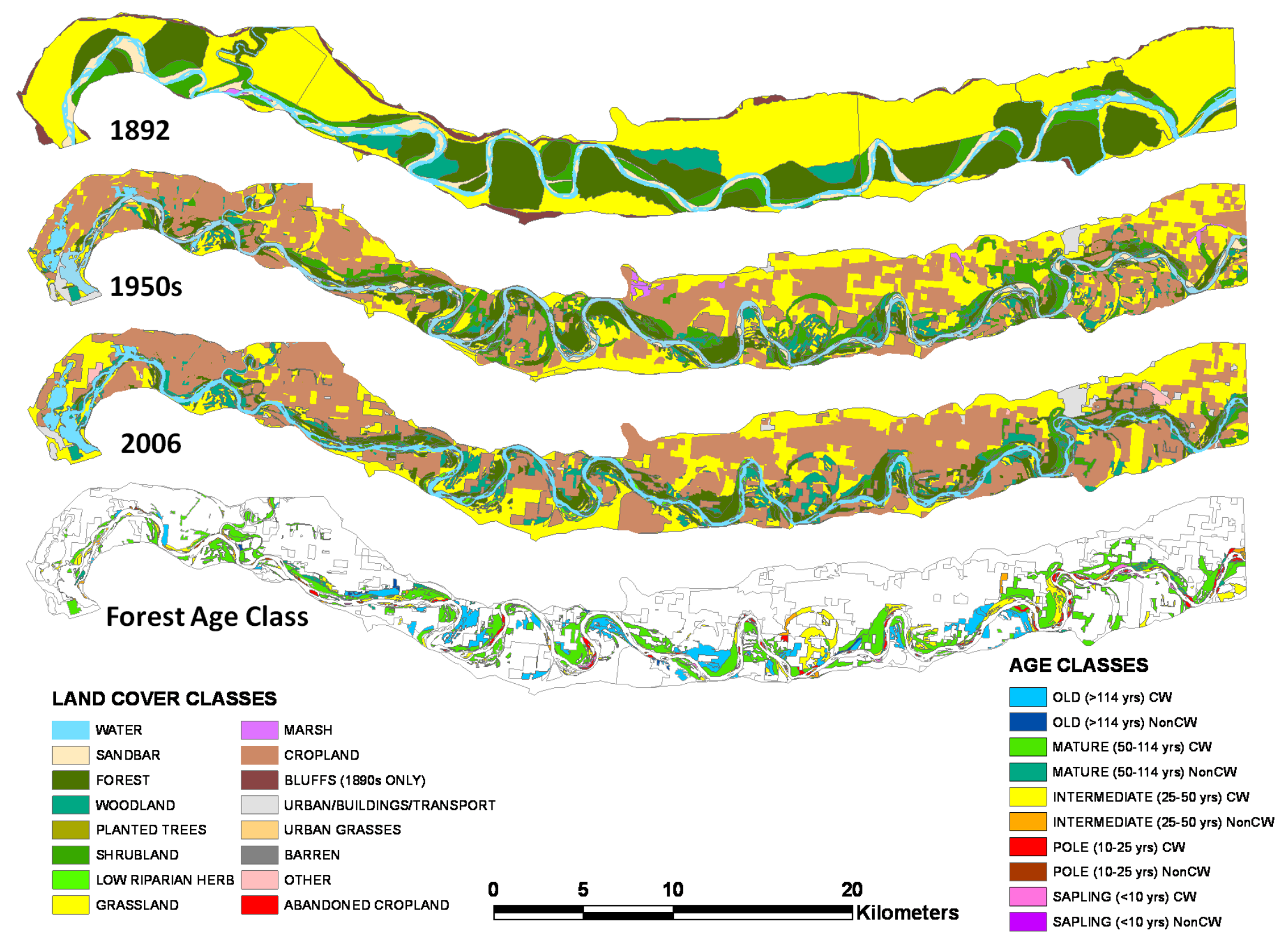


Figure A.19 - Segment 2, Subreach 2 (RM 1698 - 1626)

\section{2}
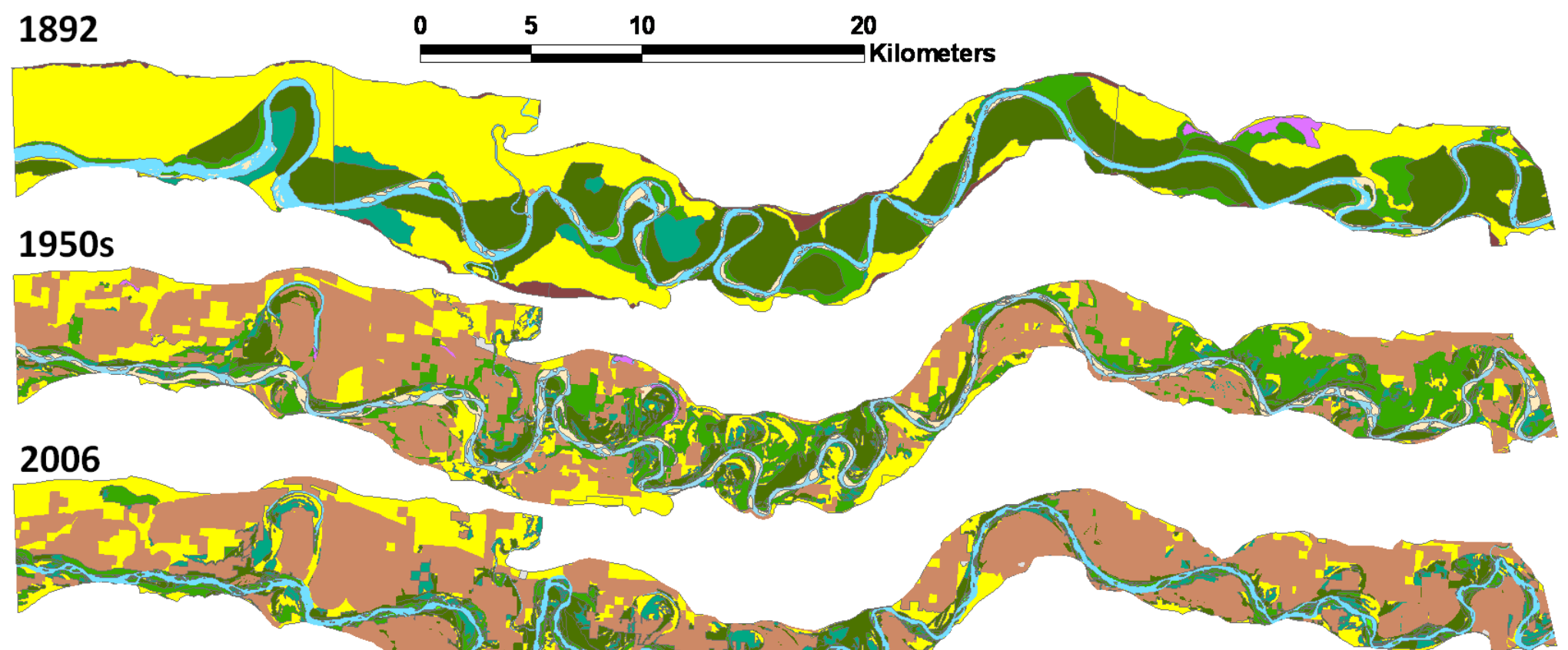

\section{Forest Age Class}

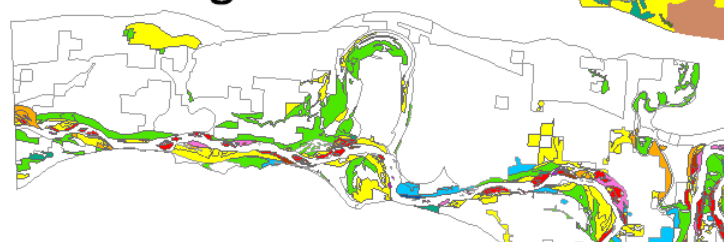

\section{LAND COVER CLASSES}

\begin{tabular}{|c|c|}
\hline WATER & MARSH \\
\hline SANDBAR & CROPLAND \\
\hline FOREST & BLUFFS (1890s ONLY) \\
\hline WOODLAND & URBAN/BUILDINGS/TRANSPORT \\
\hline PLANTED TREES & URBAN GRASSES \\
\hline SHRUBLAND & BARREN \\
\hline LOW RIPARIAN HERB & OTHER \\
\hline GRASSLAND & ABANDONED CROPLAND \\
\hline
\end{tabular}
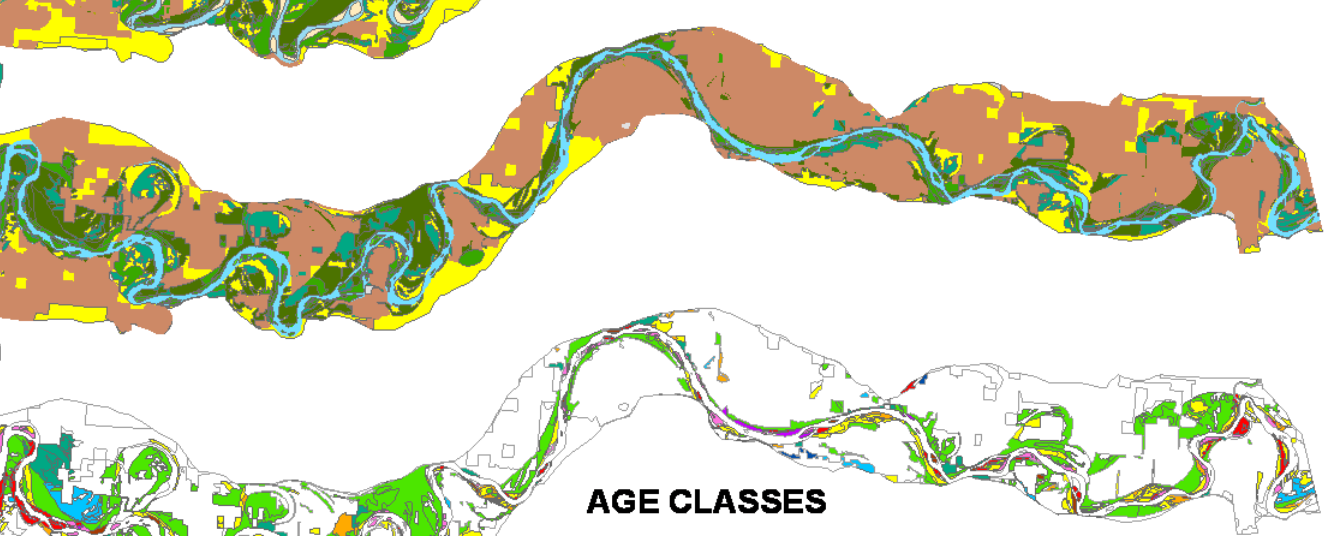
Figure A.20 - Segment 2, Subreaches 3 \& 4 (RM 1626 - 1543)

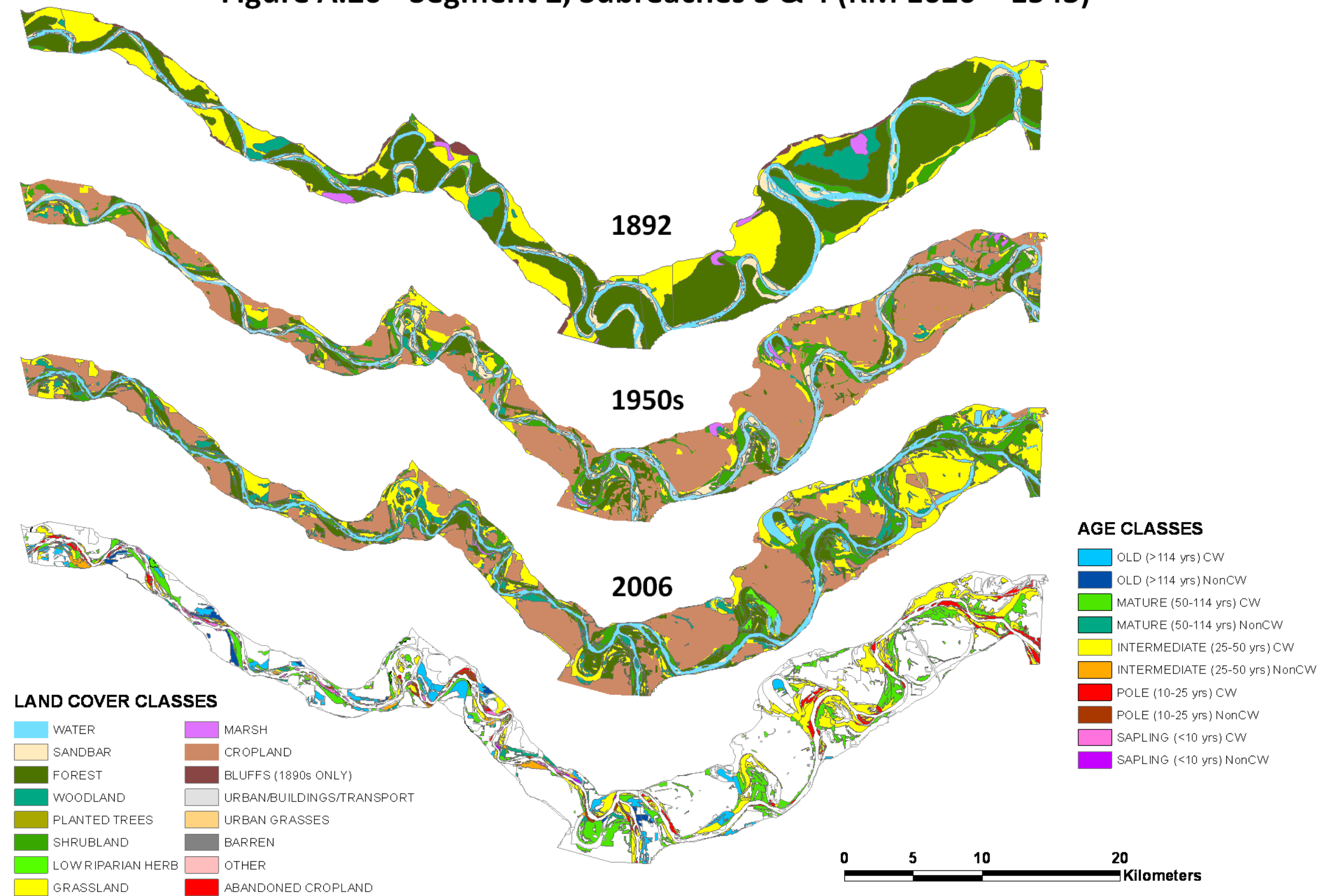


Figure A.21 - Segment 0, Subreach 1 (RM 2073 - 2027)

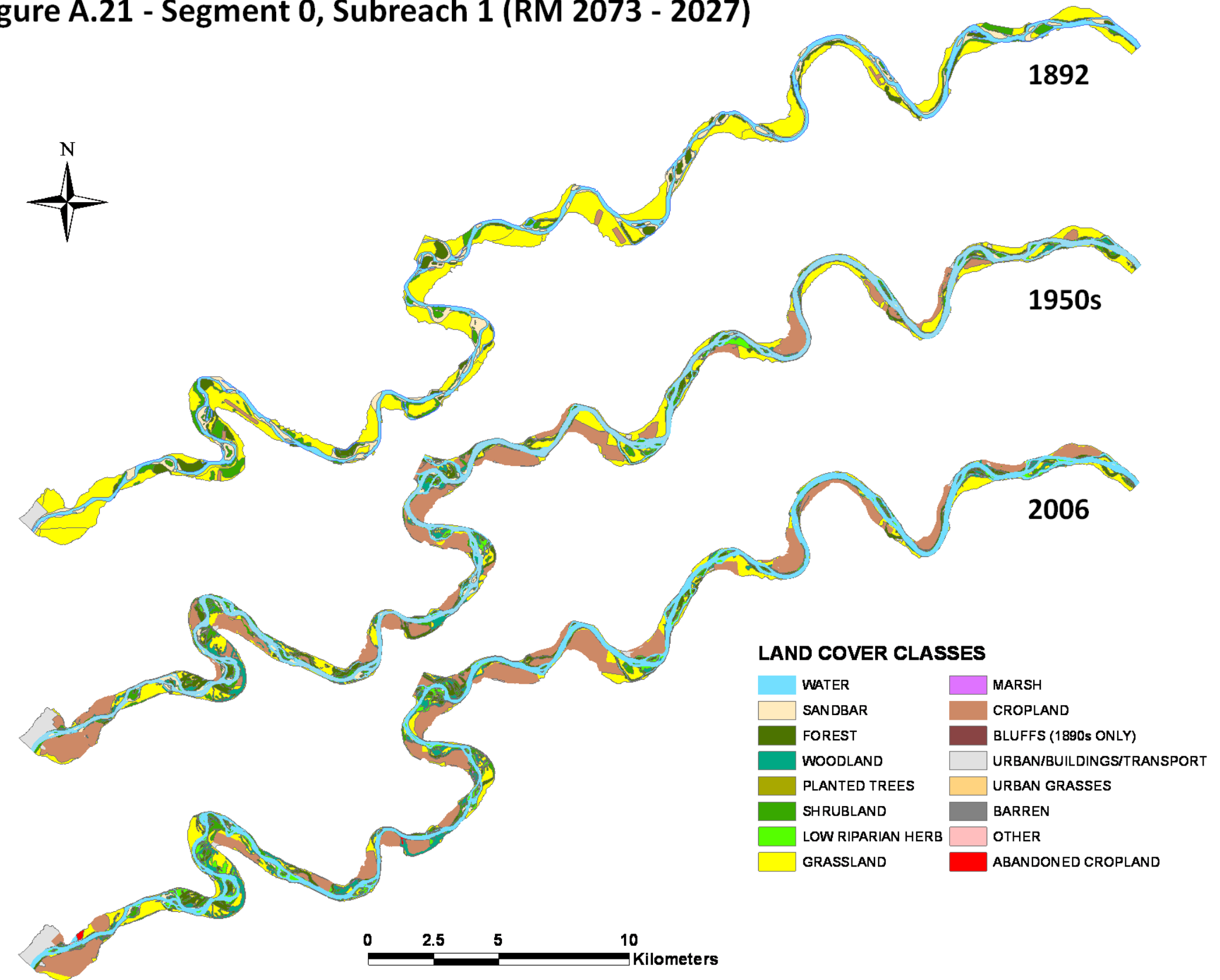




\section{Figure A.22 - Segment 0, Subreach 1 (RM 2073 - 2027)}

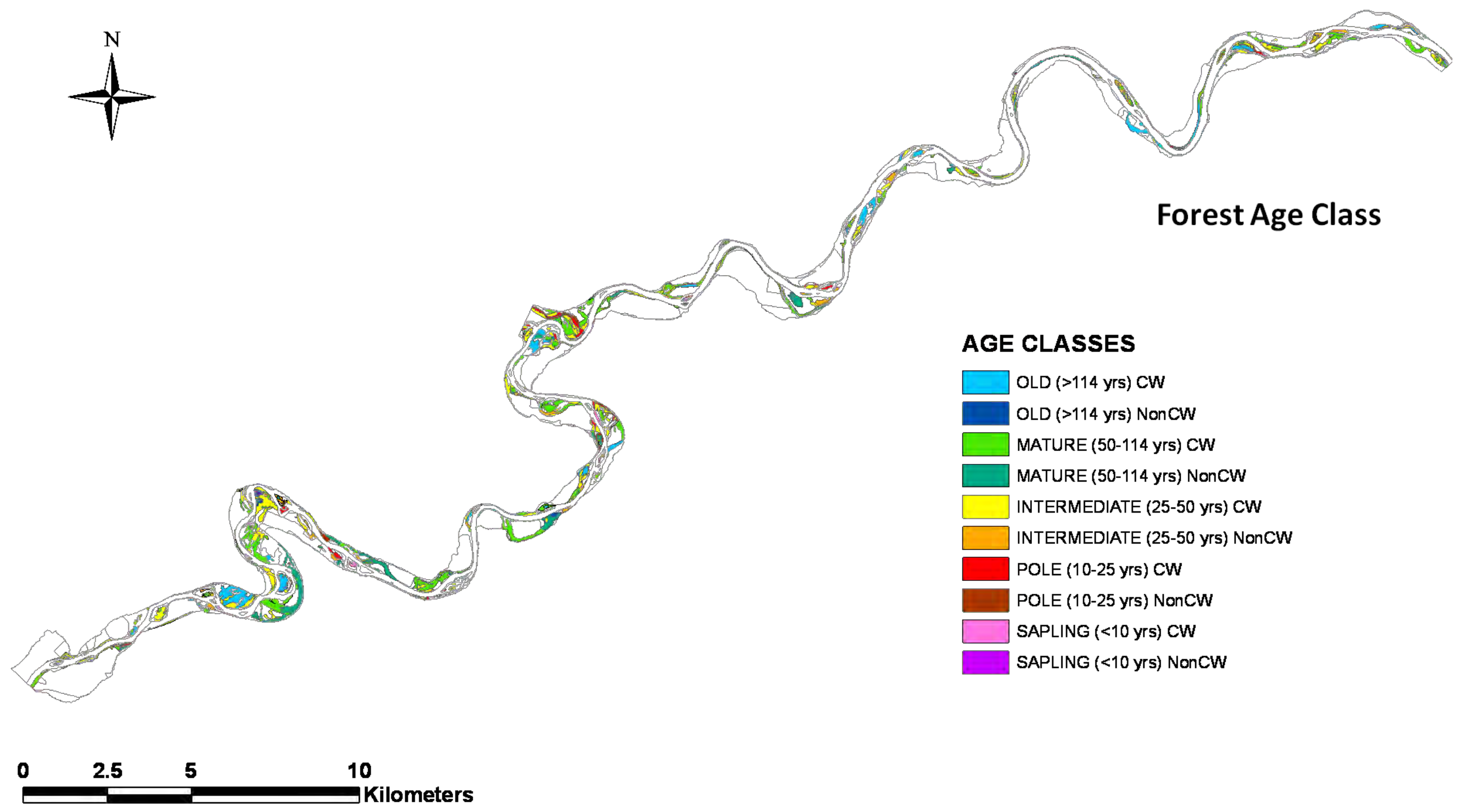




\section{Figure A.23 - Segment 0, Subreach 2, upper 1/3 (RM 2027 - 2005)}

\section{LAND COVER CLASSES}

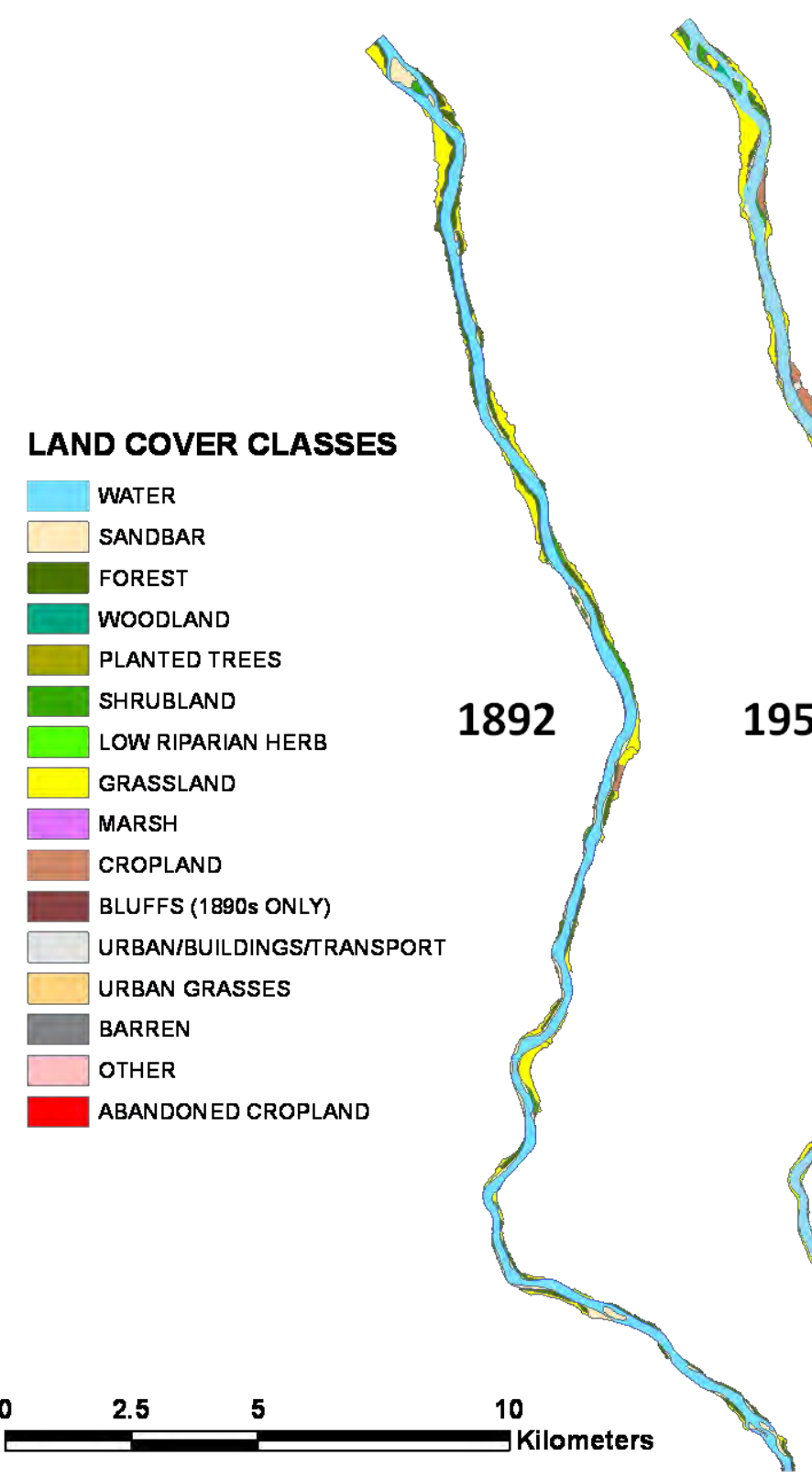

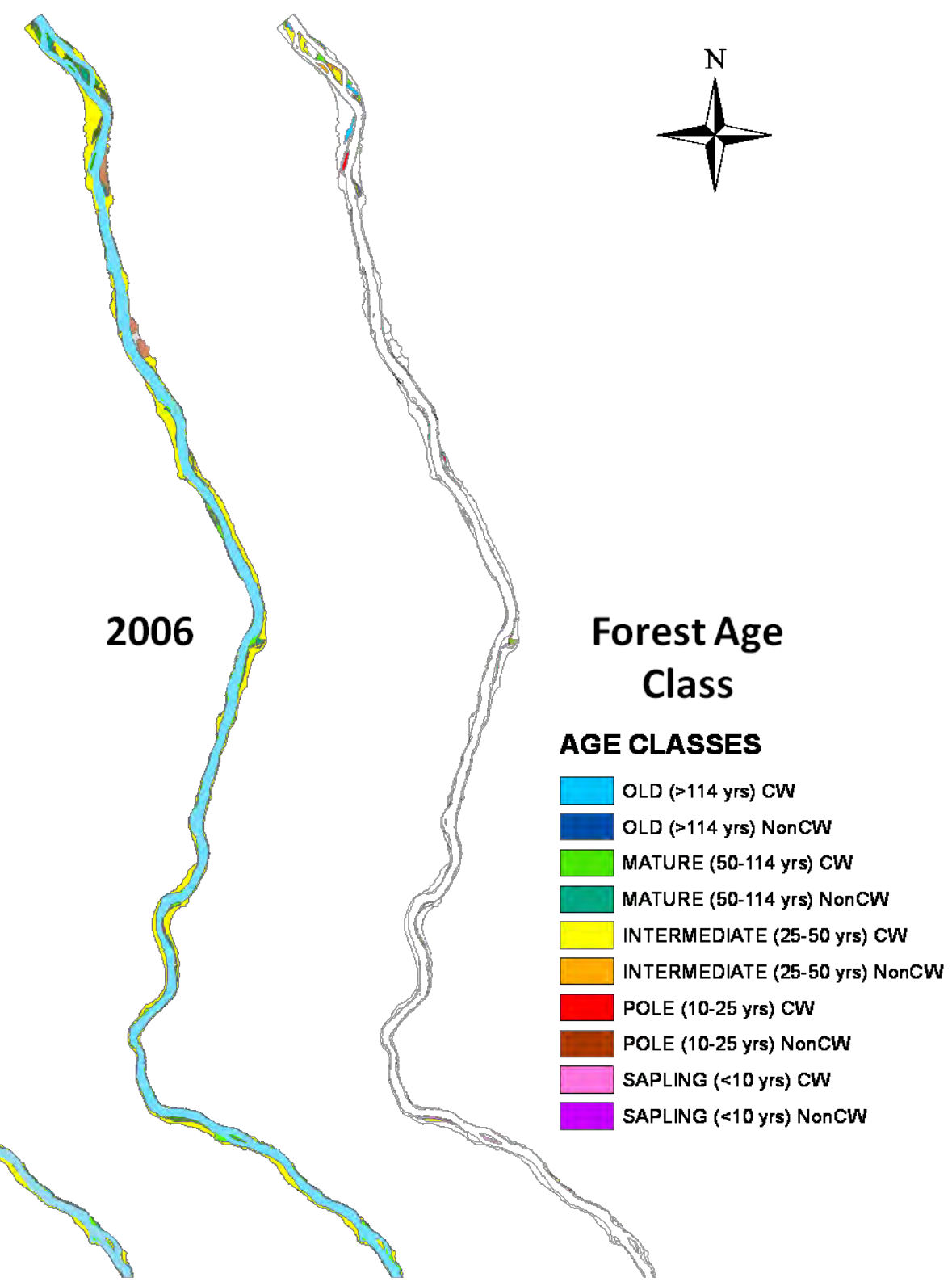

107 


\section{Figure A.24 - Segment 0, Subreach 2, middle 1/3 (RM 2005 - 1970)}

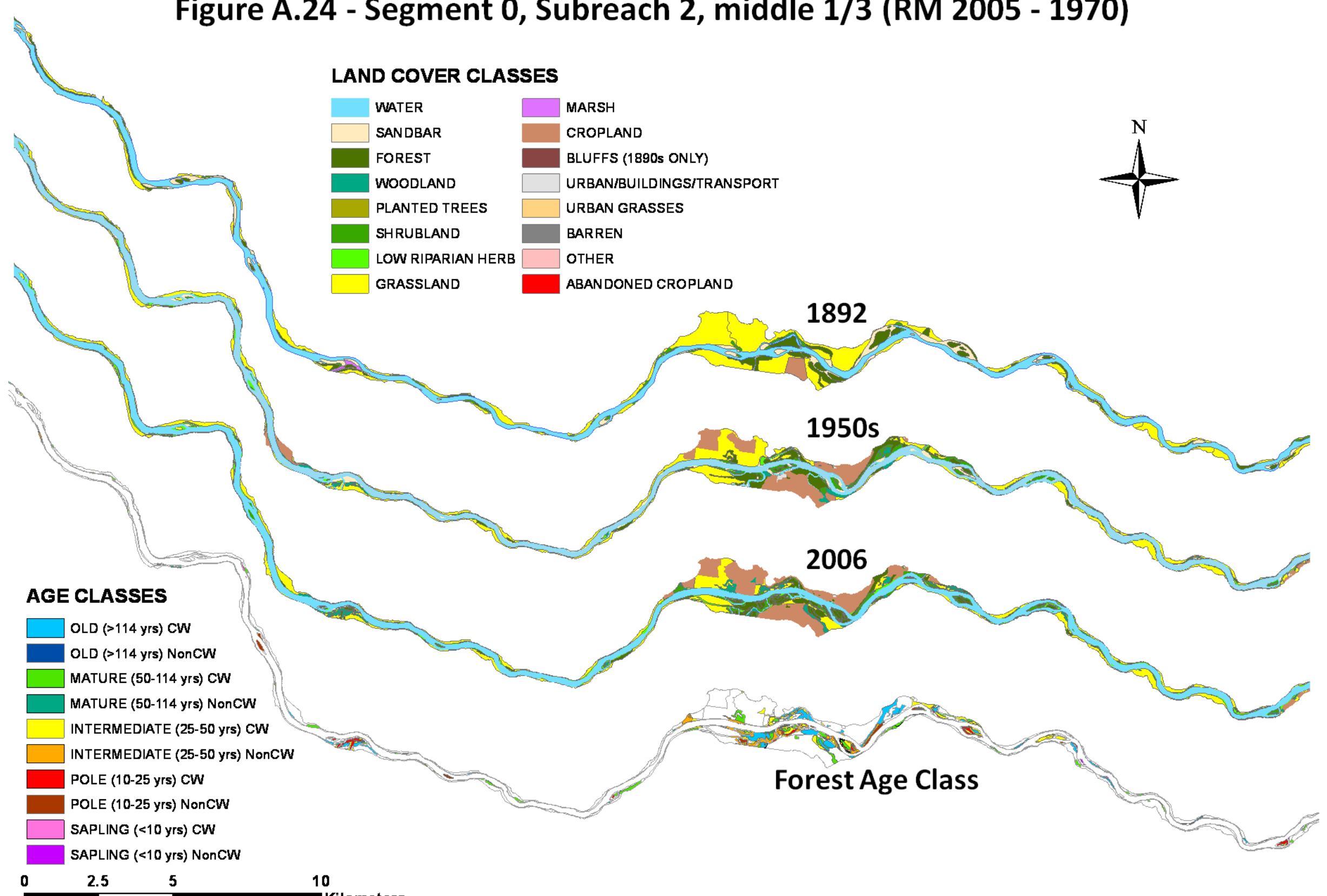


Figure A.25 - Segment 0, Subreach 2, lower 1/3 (RM 1970 - 1932)

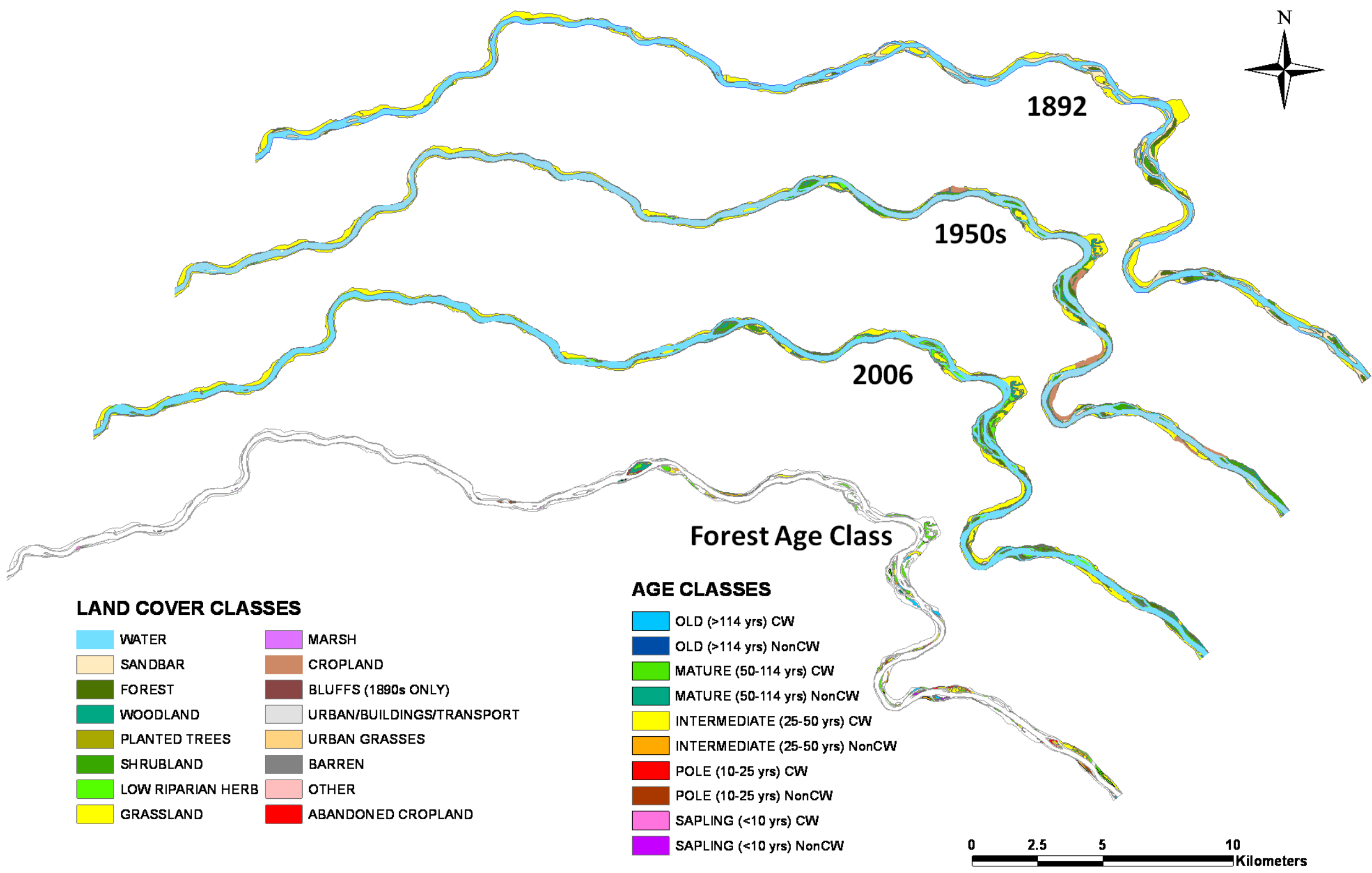


Figure A.26 - Segment 0, Subreach 3 (RM 1932 - 1917)

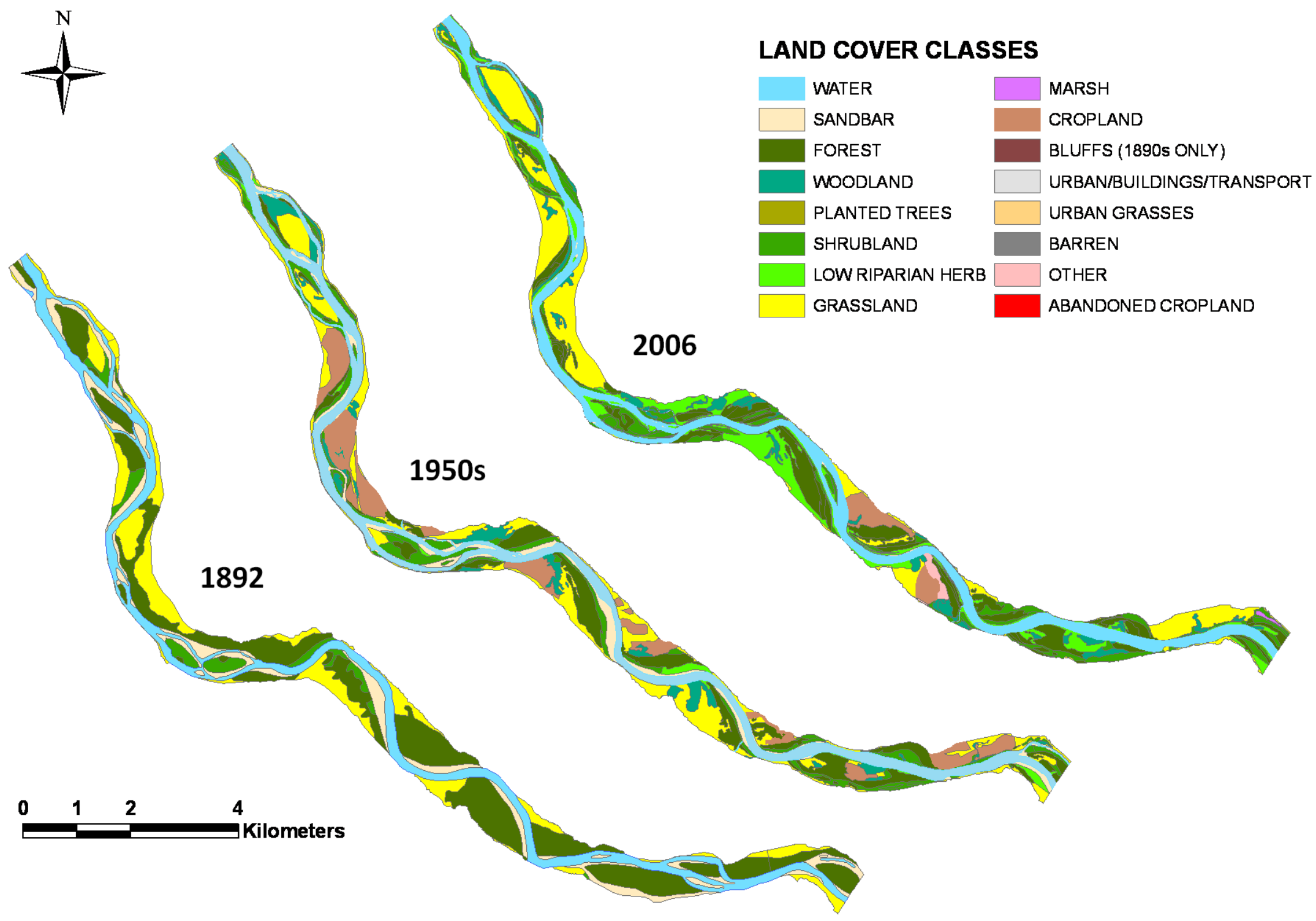


Figure A.27 - Segment 0, Subreach 3 (RM 1932 - 1917)

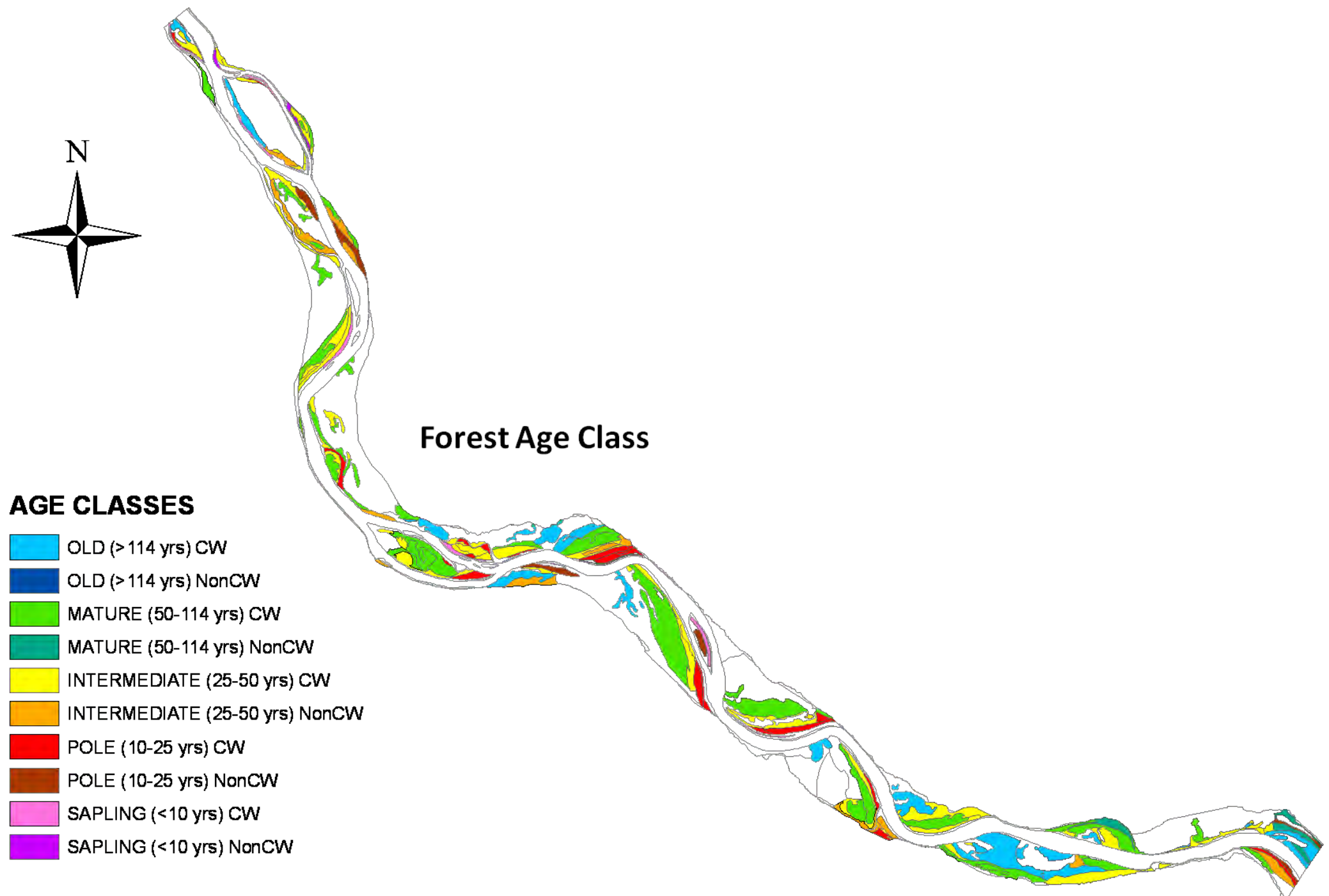

